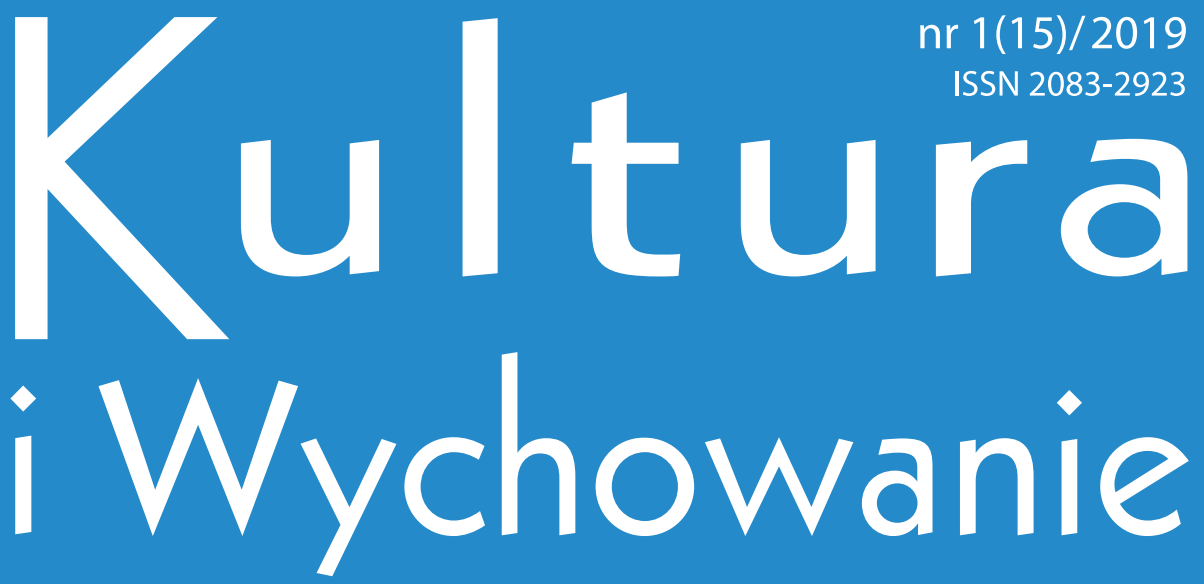

Półrocznik pedagogiczny

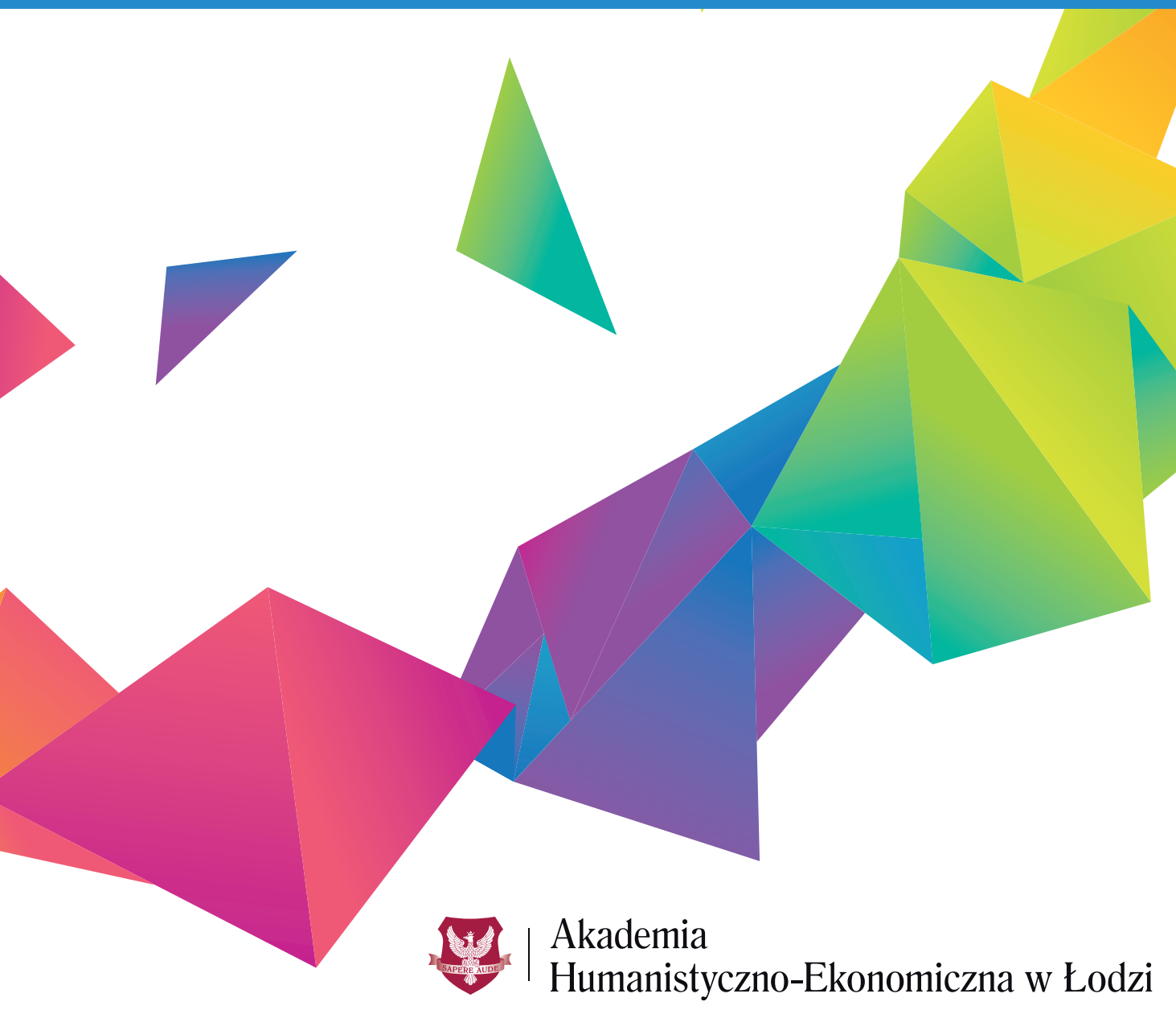



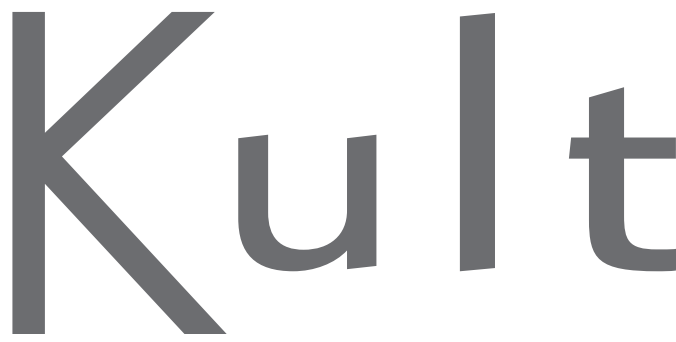

nr 1(15)/2019

ISSN 2083-2923
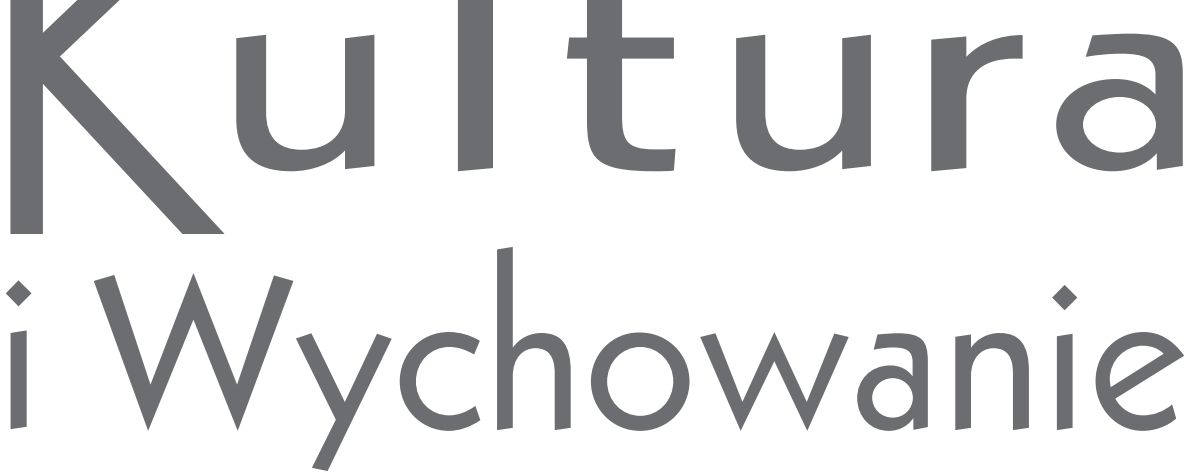

Półrocznik pedagogiczny 
REDAKCJA CZASOPISMA

Redaktor naczelny: dr Krzysztof Kamiński

Z-ca redaktora naczelnego: dr Elżbieta Woźnicka

Sekretarz redakcji: dr Agata Andrzejewska

\section{RADA NAUKOWA}

Przewodnicząca rady naukowej

dr hab. Zofia Szarota, Uniwersytet Warszawski

\section{Polska rada naukowa}

prof. dr hab. Irena Adamek, Akademia Techniczno-Humanistyczna w Bielsku-Białej prof. dr hab. Edyta Gruszczyk-Kolczyńska, Akademia Pedagogiki Specjalnej im. Marii Grzegorzewskiej w Warszawie prof. dr hab. Bożena Muchacka, Uniwersytet Pedagogiczny im. KEN w Krakowie prof. dr hab. Maria Szyszkowska, Uniwersytet Warszawski, Komitet Prognoz „Polska 2000 Plus” przy Prezydium PAN prof. dr hab. Stanisław Gałkowski, Akademia Ignatianum w Krakowie dr hab. Rafał Godoń, Uniwersytet Warszawski prof. dr hab. Krzysztof Jakubiak, Uniwersytet Gdański prof. dr hab. Lech Mokrzecki, emerytowany prof. UG, Uniwersytet Gdański prof. dr hab. Stanisław Palka, Uniwersytet Jagielloński w Krakowie dr hab. Dariusz Stępkowski, prof. UKSW, Uniwersytet Kardynała Stefana Wyszyńskiego w Warszawie prof. dr hab. Bogdan Szczepankowski, Społeczna Akademia Nauk w Warszawie dr hab. Sławomir Szczyrba, Uniwersytet Kardynała Stefana Wyszyńskiego w Warszawie (WSD w Łodzi)

dr hab. Sławomir Sztobryn, prof. ATH, Akademia Techniczno-Humanistyczna w Bielsku-Białej

\section{Międzynarodowa rada naukowa}

prof. dr hab. Blanka Kudláčová, Uniwersytet w Trnavski w Trnavie, Słowacja prof. dr hab. Naděžda Pelcová, Uniwersytet Karola w Pradze, Czechy prof. dr hab. Irina Predborska, Towarzystwo Filozofii Edukacji, Ukraina prof. dr hab. Ałła Wasyluk, Narodowa Akademia Nauk Pedagogicznych Ukrainy, Ukraina prof. dr hab. Dietrich Benner, Uniwersytet Berliński, Niemcy prof. dr hab. Rudolf Dupkala, Uniwersytet Preszowski w Preszowie, Słowacja 
RECENZENCI „Kultura i Wychowanie” nr 1(15)/2019

dr hab. Jakub Bartoszewski, prof. PWSZ, Państwowa Wyższa Szkoła Zawodowa w Koninie dr hab. Małgorzata Bereźnicka, Uniwersytet Pedagogiczny im. KEN w Krakowie dr hab. Agata Chabior, prof. UJK, Uniwersytet Jana Kochanowskiego w Kielcach prof. dr hab. Eugeniusz Józefowski, Akademia Sztuk Pięknych im. Eugeniusza Gepperta we Wrocławiu

dr hab. Anna Fidelus, prof. UKSW, Uniwersytet Kardynała Stefana Wyszyńskiego w Warszawie dr Anna Gutowska, Uniwersytet Łódzki

prof. dr hab. Wiesław Karolak, Akademia Sztuk Pięknych im. Władysława Strzemińskiego w Łodzi

prof. dr hab. Joanna Madalińska-Michalak, Uniwersytet Warszawski

dr hab. Helena Marzec, prof. AHE, Akademia Humanistyczno- Ekonomiczna w Łodzi

dr hab. Irena Motow, prof. AJD, Akademia Humanistyczno-Ekonomiczna w Łodzi

dr hab. Dorota Podgórska-Jachnik, prof. UKW, Uniwersytet Kazimierza Wielkiego w Bydgoszczy

dr Katarzyna Slany, Uniwersytet Pedagogiczny im. KEN w Krakowie

dr hab. Hanna Solarczyk-Szwec, prof. UMK, Uniwersytet Mikołaja Kopernika w Toruniu ks. dr hab. Dariusz Stępkowski, prof. UKSW, Uniwersytet Kardynała Stefana Wyszyńskie-

go w Warszawie

dr hab. Renata Szczepanik, prof. UŁ, Uniwersytet Łódzki

dr hab. Sławomir Sztobryn, prof. ATH, Akademia Techniczno-Humanistyczna w Bielsku-Białej

prof. dr hab. Ałła Wasyluk, University of Educational Management, Kyiv Ukraine

dr Kamila Witerska, Akademia Humanistyczno- Ekonomiczna w Łodzi

Redakcja czasopisma „Kultura i Wychowanie”

Akademia Humanistyczno-Ekonomiczna w Łodzi

90-212 Łódź, ul. Sterlinga 26, pok. K 108

e-mail: kulturaiwychowanie@ahe.lodz.pl

strona www: www.pedagogika.pl

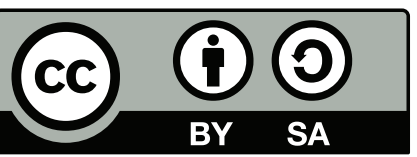

Ten utwór jest dostępny na licencji Creative Commons Uznanie autorstwa-Na tych samych warunkach 4.0 Międzynarodowe. 
(C) Copyright by Akademia Humanistyczno-Ekonomiczna w Łodzi Łódź 2019

ISSN 2083-2923

Wersją podstawową jest wersja elektroniczna

Projekt graficzny okładki

Joanna Niekraszewicz

Redaktor prowadzący

Iwona Morawska

Redakcja językowa i korekta

Elwira Zapałowska

Opracowanie typograficzne i skład DTP

Monika Poradecka

\section{Wydawnictwo}

Akademii Humanistyczno-Ekonomicznej w Lodzi

90-212 Łódź, ul. Sterlinga 26

tel. 426315908

wydawnictwo@ahe.lodz.pl

www.wydawnictwo.ahe.lodz.pl 


\section{Spis treści}

Anna Szudra-Barszcz

Filozofia wychowania Wojciecha Chudego

Edyta Zawadzka

Przygotowanie do dorosłości jako cel wychowania rodzinnego

Małgorzata Bereźnicka

Seksting i wybrane kwestie związane z seksualnością

w opiniach młodych kobiet i mężczyzn

Agata Cabała

Edukacja muzealna w praktyce szkolnej - wyzwania dydaktyczne.

Magdalena Arczewska

Dobro dziecka w perspektywie sędziów rodzinnych

i służb społecznych - kontekst wsparcia rodziny naturalnej

w odzyskiwaniu opieki nad dzieckiem

Małgorzata Karczmarzyk, Dominika Szelągowska

Analiza wizualno-werbalna wybranych książek dla dzieci

o biografiach sławnych artystów malarzy

Agnieszka Domagała-Kręcioch

Refleksje wokół szkolnej kultury błędu

Małgorzata Kierzkowska, Karolina Skarbek

Dobrobyt materialny rodziny a marzenia dzieci w kontekście dobrostanu psychicznego

Karolina Gniazdowska

Specjalne potrzeby edukacyjne uczniów z rdzeniowym zanikiem mięśni (SMA) . 
Rafał Maliszewski

Internet a wychowanie - na przykładzie Katolickiej Szkoły

Podstawowej im. Piotra Dunina w Chojnicach

Renata Matusiak

Edukacja medialna „pokolenia kciuka” - błahostka czy obowiązek? ... 161

Agnieszka Krawczyk

The meaning of Jewish culture of origin for Jewish women from

the third generation.

Roksana Pilawska

Baśnie jako przestrzeń socjalizacji - na przykładzie baśniowego

wizerunku matki

Paulina Białka

Jeden uniwersytet a dwa światy - analiza porównawcza koncepcji

studiowania

Małgorzata Mróz

Obraz i wsparcie dziecka nieśmiałego w percepcji nauczycieli

edukacji przedszkolnej 


\section{Contents}

Anna Szudra-Barszcz

Wojciech Chudy's Philosophy of Education

Edyta Zawadzka

Preparation for adulthood as an objective of upbringing.

Małgorzata Bereźnicka

Sexting and other issues related to sexuality:

The opinions of young women and men

Agata Cabała

Museum education in school practice - didactic challenges.

Magdalena Arczewska

Child welfare from the perspective of family judges

and social services in the context of supporting the biological family

in regaining custody over the child

Małgorzata Karczmarzyk, Dominika Szelagowska

Visual-verbal analysis of selected picture book biographies

of famous painters

Agnieszka Domagała-Kręcioch

Reflections on a school's mistake culture

Małgorzata Kierzkowska, Karolina Skarbek

Family material well-being and children's dreams in the context

of psychological well-being.

Karolina Gniazdowska

Special educational needs of students with spinal muscular atrophy (SMA). 
Rafał Maliszewski

Internet and education - based on the Piotr Dunin

Catholic Primary School in Chojnice

Renata Matusiak

Media education of the "thumb generation" - triviality or duty?

161

Agnieszka Krawczyk

The meaning of Jewish culture of origin for Jewish women from

the third generation.

Roksana Pilawska

Fairytales as a space for socialization - on the example

of a fairytale image of the mother.

Paulina Białka

One University and two worlds - comparative analysis

of studying concepts.

Małgorzata Mróz

A picture of and support for the timid child in the perception

of pre-school education teachers 


\title{
Filozofia wychowania Wojciecha Chudego
}

DOI: 10.25312/2083-2923.15/2019_14asb

\begin{abstract}
Streszczenie: Filozofia wychowania Wojciecha Chudego nabudowana jest na personalistycznej koncepcji człowieka, która łączy podejście metafizyczne (podkreślając stałość i niezmienność pierwiastków osobowych) z nowożytnym (akcentując podmiotowość i dynamizm osoby), co skutkuje koncepcją człowieka jako będącego i zarazem stającego się osobą w toku całego swego życia. Dynamizm osoby Wojciech Chudy upatruje przede wszystkim w płaszczyźnie moralnej. Taka perspektywa pozwala mu określić wychowanie jako samowychowanie, które odbywa się w spotkaniu z drugim człowiekiem.
\end{abstract}

Słowa kluczowe: Wojciech Chudy, filozofia osoby, godność osobowa, wychowanie, samowychowanie

\section{Wstęp}

Przedmiotem poniższych rozważań jest Wojciecha Chudego ujęcie filozofii wychowania. Ich cel sprowadza się do przedstawienia podstawowych treści tej koncepcji. Jego realizacja będzie się składała $\mathrm{z}$ czterech głównych etapów (zorganizowanych w cztery, wyróżnione tytułami, części artykułu). Wpierw - ze względu na to, że wychowanie w sensie ścisłym stało się obiektem dociekań Wojciecha Chudego dopiero w ostatniej dekadzie jego życia - nakreślę główne wątki jego filozoficznych badań, jak również wskażę na ich inspiracje. Następnie przybliżę metodologiczne stanowisko Wojciecha Chudego w kontekście niektórych aporii pojęciowych związanych z rozumieniem filozofii wychowania. W części trzeciej artykułu zarysuję historiozoficzne podstawy tego stanowiska. Natomiast w ostatnich akapitach scharakteryzuję rdzeń jego filozofii wychowania.

* Anna Szudra-Barszcz - doktor nauk humanistycznych w zakresie pedagogiki; magister filozofii. Miejsce pracy: Katedra Pedagogiki Porównawczej i Filozofii Wychowania, Instytut Pedagogiki KUL. Główne obszary badań: filozofia wychowania, etyka pedagogiczna, etyczne aspekty pedagogiki specjalnej. 


\section{Filozofia Wojciecha Chudego}

Wojciech Chudy był filozofem. Studia wyższe odbył w Katolickim Uniwersytecie Lubelskim na Wydziale Filozofii Chrześcijańskiej, kształcąc się m.in. pod kierunkiem M.A. Krąpca, A.B. Stępnia, T. Stycznia oraz S. Kamińskiego. Stopień doktora uzyskał (1980 r.) na podstawie obrony rozprawy Refleksja „in actu exercito” i jej funkcja w poznaniu metafizykalnym. Stopień doktora habilitowanego uzyskał (1993 r.) na podstawie dysertacji Rozwój filozofowania a „pułapka refleksji”. Filozofia refleksji i prób jej przezwyciężania. Filozofia refleksji i ukazywany przez jej pryzmat człowiek odcisnęły swoje piętno na jego rozumieniu osoby, później również na rozumieniu wychowania. Poza filozofią poznania i filozofią człowieka głównymi obszarami zainteresowań badawczych Wojciecha Chudego były: myśl filozoficzna G.W.F. Hegla, filozofia K. Wojtyły (po 1978 r. nauczanie Jana Pawła II), filozofia kłamstwa oraz - w ostatnich latach pracy - filozofia wychowania i etyka pedagogiczna. Pracę w Katedrze Filozofii Wychowania przy Instytucie Pedagogiki KUL, rozpoczął w 1996 r., pełniąc funkcję jej kierownika do śmierci - 15 marca 2007 r. Systematyczną refleksję nad fenomenem wychowania, związaną z prowadzeniem wykładów i seminariów dla studentów Instytutu Pedagogiki KUL, podjął zatem po prawie dwudziestu latach od rozpoczęcia swojej pracy naukowej.

Należy dodać, że Wojciech Chudy był nie tylko naukowcem, ale również publicystą. W swoich licznych felietonach oraz w wykładach głoszonych dla osób spoza kręgów akademickich (w latach osiemdziesiątych dla działaczy opozycji solidarnościowej oraz słuchaczy Tygodni Kultury Chrześcijańskiej, w ostatnich latach życia dla nauczycieli i wychowawców ${ }^{1}$ ) popularyzował - jak zwykł mawiać - filozofię bez przesady, bliską człowiekowi i jego życiu. Uczył filozofii „[...] nie jako umiłowania mądrości dla samej mądrości, która byłaby podszyta stoickim dystansem wobec tak zwanego codziennego życia, ale filozofii tłumaczącej, wyjaśniającej, interpretującej życie i ludzkie sprawy" ${ }^{2}$. Będąc głęboko przekonanym o osobowym wymiarze refleksji, potrafił budzić ją w innych.

Należy podkreślić, że wymienione główne obszary zainteresowań badawczych Wojciech Chudego - nawet filozofia Hegla ${ }^{3}$ - znajdują swój rys w jego filozofii wy-

${ }^{1}$ Zob. m.in.: W. Chudy, Filozofia wieczysta w czas przełomu. Gdańskie wykłady z filozofii klasycznej z roku 1981, TN KUL, Lublin 2008 (książka jest redakcyjnym opracowaniem serii wykładów wygłoszonych przez Wojciech Chudego w maju 1981 r., na zaproszenie Ośrodka Prac Społeczno-Zawodowych przy MKZ-ecie „Solidarności” gdańskiej) oraz tenże, Jan Paweł II - nauczyciel kultury. Osoba ludzka znakiem trudu i nadziei, [w:] Osobowy wymiar kultury. Materiały XV Ogólnopolskiego Forum Szkół Katolickich, Redakcja Szkół Katolickich, Warszawa 2004.

2 E. Smołka, Profesor i nauczyciel, „Ethos”, nr 79-80/2007, s. 271.

${ }^{3}$ Do filozofii Hegla odnosił się W. Chudy m.in. w analizie sensu umierania. Doczesność opisywał jako „królestwo zmiany”. Natomiast każde przeobrażanie następujące w życiu człowieka wiązał z szansą jego stawania się, to zaś z samowychowaniem. „[... [ każdy akt życia ludzkiego, każde przeżycie, jakiego człowiek doznaje, stając się i przemijając - wpisuje się w rytm bytu opisywany przez 
chowania. Pomimo rozległego wachlarza filozoficznych odniesień pozostał jednak konsekwentnie, niekiedy „do bólu” (jak powtarzało wielu spośród seminarzystów Profesora, przeżywających w trakcie studiów „kryzys” filozofii osoby) personalistą. Jako uczeń T. Stycznia, w nawiązaniu nie tylko do filozofii K. Wojtyły, A. Rodzińskiego i M.A. Krąpca, ale również E. Mouniera i M. Schelera, budował swoją filozofię wychowania w oparciu o kategorie szeroko rozumianej filozofii osoby. Zasadnicze momenty swojej refleksji nad wychowaniem (zwłaszcza koncepcję samowychowania) wyprowadzał zaś z etycznego nurtu personalizmu.

\section{Filozofia wychowania a filozofia pedagogiki}

W badaniach sytuujących się na pograniczu filozofii i pedagogiki można wskazać na dwa podstawowe podejścia. Pierwsze koncentruje się na samym wychowaniu - podejście to ujmuje wychowanie jako określoną rzeczywistość, fenomen lub fakt (kulturowy, społeczny itp.). Drugie dotyczy pedagogiki jako dyscypliny naukowej $^{4}$. W związku z tym przyjęło się używać w języku pedagogicznym, niestety często zamiennie, trzech różnych terminów: filozofia wychowania/pedagogika filozoficzna, filozofia pedagogiki oraz filozofia edukacji ${ }^{5}$. Określane przez nie dziedziny poszuki-

Hegla" (zob. W. Chudy, Odchodzenie z nadzieja. U podstaw pedagogiki umierania, [w:] K. Mielcarek (red.), Dar i tajemnica śmierci. Tydzień eklezjologiczny 2006. W trosce o Kościót, t. VII, Polihymnia, Lublin 2007, s. 126).

${ }^{4}$ Oba podejścia, choć niepotraktowane w sposób systematyczny, znajdują swoje odbicie w filozofii wychowania W. Chudego. Widać to zwłaszcza w: charakterystyce relacji między filozofią i pedagogiką, rozróżnianiu podstawowych kategorii pedagogicznych (edukacji, kształcenia i wychowania) oraz analizie wychowania w perspektywie personalistycznej koncepcji człowieka, będącej skutkiem opowiedzenia się za pierwszym $\mathrm{z}$ wymienionych podejść.

${ }^{5}$ Terminy te doczekały się różnych definicji. Próby ich systematyzacji podejmowali m.in. L. Witkowski i S. Sztobryn. Pierwszy z nich pedagogikę filozoficzną metodologicznie wiąże zarówno z pedagogiką, jak i z filozofią wychowania i filozofią edukacji (przez wzgląd na określone, filozoficzne podejście do problemów pedagogicznych). Ponadto kładzie on nacisk na konieczność dostrzegania pedagogicznego wymiaru samej filozofii (posługuje się nawet terminem „filozofia pedagogiczna"). Jednocześnie podkreśla, że dociekania w tych zakresach nie powinny być ukierunkowane na poszukiwanie tożsamości naukowej badacza ani nawet tożsamości uprawianej dyscypliny, ale na rozumienie „złożoności sytuacji pedagogicznych i tryb sprostania tym sytuacjom, które przecież [...] muszą odnosić się z jednej strony do wartości i norm, z drugiej - do projektów, wizji i założeń refleksyjnie uzasadnianych, z trzeciej zaś do wymogów realnej i samokrytycznej oceny szans powodzenia i jakości własnych nadziei, aż po iluzje, złudzenia, pułapki czy paradoksy" (M. Jaworska-Witkowska, L. Witkowski, Pedagogika filozoficzna: relacje między pedagogika, filozofia i humanistyka a edukacją, kultura i życiem społecznym, [w:] B. Śliwerski (red.), Pedagogika. Subdyscypliny i dziedziny wiedzy o wychowaniu, GWP, Gdańsk 2010, s. 2; zob. L. Witkowski, Między pedagogika, filozofia i kulturą. Studia, eseje, szkice, t. 3, Instytut Badań Edukacyjnych, Warszawa 2007). Z kolei S. Sztobryn pedagogikę filozoficzną i filozofię wychowania traktuje jako pojęcia symetryczne. Precyzując natomiast znaczenie pedagogiki filozoficznej, podobnie zresztą jak W. Chudy, wskazuje na jej ścisły związek z filozofią zarówno w kontekście treściowym, metodologicznym, jak i historiozoficznym (zob. m.in.: S. Sztobryn, Pedagogika i filozofia - wzajemne relacje. Stanowisko pedagogów 
wań, przyjmując wprawdzie wspólny mianownik - filozoficzny namysł nad wychowaniem i pedagogiką, różnią się jednak w rozumieniu swego przedmiotu. Fakt ten pociąga za sobą inne cele badawcze oraz odmienną metodologię.

F i l o z of i a w y c h o w a n i a to jedna z subdyscyplin pedagogicznych, której podstawowymi celami są: filozoficzna analiza i interpretacja wychowania oraz wskazanie na jego metafizyczne, antropologiczne, etyczne, aksjologiczne, ewentualnie (np. w krytycznej filozofii wychowania) ideologiczne aspekty. Tak rozumiana filozofia stawia sobie za cel odpowiedź m.in. na pytania: czym jest wychowanie?, jakie są jego źródła i cele?, jak się przejawia w życiu człowieka? Pytania te pozostają w ścisłym związku (co stanowi o ich filozoficznym charakterze) z bardziej ogólnym pytaniem o człowieka, jego miejsce w świecie, stosunek do rzeczywistości, kryteria dobra moralnego, szczęścia itp. W tym zakresie badawczym mieści się też historyczno-filozoficzny przegląd stanowisk dotyczących szeroko rozumianej filozofii wychowania oraz problemu relacji między filozofią a pedagogiką.

Fil o z of i a pe da g o gi ki to dyscyplina, której zakres badań wyznacza refleksja nad teoretycznymi podstawami pedagogiki jako nauki. Uprawiana jako swoista metodologia, której podstawowym celami są: określenie statusu metodologicznego pedagogiki, określenie zakresu jej treści i podstawowych pojęć (języka) oraz uniezależnienie (zautonomizowanie) jej od innych dyscyplin zajmujących się wychowaniem. W ramach metodologii pojęcia „wychowanie” i „edukacja” są kategoriami, które łączą i integrują poszczególne dyscypliny pedagogiczne ${ }^{6}$.

Fil o z ofia e d u ka c ji różni się od poprzednich tym, że związana jest ściśle z praktyką pedagogiczną. Popularność tego pojęcia łączy się z szeroko dziś dyskutowanym kryzysem wychowania (niekiedy także samej pedagogiki), ten zaś z kryzysem aksjologicznych podstaw społeczeństwa. Wyznaczając filozofii edukacji zadania praktyczne, stawia się ją niekiedy na równi z etykami szczegółowymi (m.in. etyką biznesu, etyką badań naukowych, etyką ekologiczną) jako dyscyplinami, któ-

okresu międzywojennego w świetle literatury czasopiśmiennej, „Colloquia Communia”, nr 2/2003, s. 25-39; tenże, Filozofia wychowania w Polsce w XX wieku. Zarys problematyki, „Medodiczni Studii. Zbirnik Naukowo-Metodicznich Prac", Wipusk 2, Donieck 2012).

${ }^{6}$ Zob. A. Bronk, Pedagogika ifilozofia: uwagi metafilozoficzne, [w:] P. Dehnel, P. Gutowski (red.), Filozofia a pedagogika. Studia i szkice, Wydawnictwo Naukowe Dolnośląskiej Szkoły Wyższej Edukacji TWP we Wrocławiu, Wrocław 2005, s. 22-25. Według A. Bronka, obecność filozofii w pedagogice zaznacza się w dwóch płaszczyznach: formalnej i treściowej. Pierwsza dotyczy uprawomocniania (uzasadniania, konfirmacji, sprawdzania, rozstrzygania) twierdzeń i teorii pedagogicznych. Druga zaś kontekstu odkrycia (porządku heurezy, inspiracji) tych twierdzeń i teorii. „Filozofia występuje w funkcji uprawomocniającej, kiedy pedagog uzasadnia własne poglądy, powołując się na tezy lub teorie filozoficzne. W aspekcie metodologicznym filozofia jest obecna, kiedy - jako logika, epistemologia lub filozofia nauki - określa ogólnie cele badania naukowego oraz dostarcza pedagogice narzędzi badawczych w postaci formalnej aparatury pojęciowej, ogólnych reguł postępowania naukowego" (tamże, s. 23). 
rych rozwój przysłużyć się może regulacji praktyk społecznych ${ }^{7}$. W związku z tym filozofii edukacji wyznacza się następujące zadania: dostarczanie podstaw reformie edukacji (formalnych i treściowych) oraz narzędzi do oceny postulowanych przemian (1); dostarczanie celów edukacji i wychowania oraz takie ich uzasadnienie, by społeczeństwo zaakceptowało wartość edukacji i w konsekwencji skłonne było wpływać na politykę oświatową (m.in. dostosowywać inne systemy - np. budżet - do potrzeb edukacji) (2); budowanie samoświadomości człowieka (głównie przez wprowadzenie do kanonu przedmiotów szkolnych lekcji filozofii) $(3)^{8}$.

Wojciech Chudy dostrzegał związek pedagogiki i filozofii, podkreślając zarówno formalną, jak i treściową zależność pierwszej od założeń i metody drugiej. Filozofia, jego zdaniem, dostarcza pedagogice zarówno podstaw przedmiotowych (określając m.in. koncepcję człowieka), jak i formalnych (będąc podstawą do uzasadnienia niektórych twierdzeń pedagogicznych). Według niego, pedagogika w swoim wymiarze teoretycznym potrzebuje filozofii. Potrzeba ta wyraża się w trzech płaszczyznach: w płaszczyźnie metafizyki - aby w zakresie swojego przedmiotu nie stracić kontaktu z człowiekiem realnym i konkretnym (1); w płaszczyźnie a n t ro p o logi filozoficznej bądź te ologicznej - by określać dziedzinę wychowania człowieka pełnego i integralnego; teorie wychowania powinny bowiem odpowiadać nie tylko potrzebom wyznaczonym przez „tu i teraz” konkretnego wychowanka, ale również obiektywnej prawdzie o człowieku (2); w płaszczyźnie e t y k i - aby mieć ścisły związek z praktyką pedagogiczną (3).

$\mathrm{Z}$ metodologiczną więzią między pedagogiką a filozofią łączy się, według Wojciecha Chudego, problem filozofii wychowania, która ma względem pedagogiki podwójną funkcję: ukazywania jej podstaw filozoficznych (funkcja metaprzedmiotowa) - dlatego wydaje się, że bardziej właściwym określeniem jest filozofia pedagogiki, oraz poszukiwania i określania fundamentów wychowania i pedagogiki (funkcja przedmiotowa), z czym związane jest również budowanie adekwatnej wobec nich koncepcji wychowania. Jego propozycja filozofii wychowania skupia się na drugiej z wymienionych. Określa specyfikę wiedzy pedagogicznej jako poznania opartego na rozumieniu człowieka, nie zaś na opisie ilościowym, charakterystycznym dla nauk przyrodniczych. W ten sposób precyzuje poznanie pedagogiczne jako poznanie w pełni humanistyczne. Specyfiką tego poznania jest wartościowanie, które zakłada zawsze odniesienie do określonej aksjologii i zawartej w niej hierarchii ${ }^{9}$.

${ }^{7}$ Chodzi tu szczególnie o takie reformowanie systemu edukacji, by stała się nie tylko edukacją intelektu, ale również charakteru (zob. A. Lekka-Kowalik, Filozofia edukacji i edukacja filozoficzna - antidotum na kryzys?, [w:] P. Jaroszyński, P. Tarasiewicz, I. Chłodna (red.), Filozofia i edukacja. Materiały z sympozjum z cyklu „Przyszłość cywilizacji Zachodu”, zorganizowanego przez Katedre Filozofii Kultury, Fundacja „Lubelska Szkoła Filozofii Chrześcijańskiej”, Lublin 2005, s. 180-181).

${ }^{8}$ Zob. tamże, s. 181.

9 Por. W. Chudy, Pedagogia godności. Elementy etyki pedagogicznej, TN KUL, Lublin 2009, s. 21 nn.; tenże, Między Werterem a Stawroginem - albo wartości w życiu człowieka, maszynopis w posiadaniu autorki (A. Sz.-B.). Bez wartości, co więcej, bez określonej ich hierarchii, „[...] świat stałby się 
Przedmiotem tak rozumianej pedagogiki jest człowiek postrzegany jako osoba dana i zadana (sobie i innym). Jako dana, czyli ta, która już jest (istnieje odrębnie od innych bytów); jako zadana (potencjalna), czyli ta, która dopiero ma powstać. Rozpatrywany jest zatem w przestrzeni całego swojego życia. W aspekcie swojej przeszłości, teraźniejszości, jak i przyszłości. W tej perspektywie kwestią podstawową jest wskazanie na adekwatną koncepcję człowieka, ukazującą i wyjaśniającą ów szczególny sposób bytowania (bycie osobą) oraz jego dynamizm (stawanie się osobą). W. Chudy mawiał, że zarówno filozofia, jak i pedagogika potrzebują nie tylko prawdy o człowieku - systemowo ujętej - ale również prawdy człowieka - prawdy jego życia, ujętej w perspektywie przeżyciowej, subiektywnej ${ }^{10}$. Człowiek postrzegany przez pryzmat tych dwóch prawd j e s t o s o b ą (obdarzoną fundamentalną, niezbywalną wartością, którą stanowi godność osobowa) i permanentnie s t a j e s i ę o s ob ą (głównie w płaszczyźnie moralnej, potwierdzając wartość osobowej godności). Nie jest i w perspektywie moralnej nie może być - bytem ostatecznie określonym, ale bytem rozwijającym się, stale dążącym do celu, którym - w perspektywie ostatecznej - jest osobowy Bóg, racja istnienia i rozwoju osoby ludzkiej. Człowiek bowiem w wymiarze osobowym staje się aż do śmierci, która jest ostatnim, przez niektórych określanym jako szczytowy, aktem osoby. Wyrazem dowartościowania pedagogicznych aspektów procesu osobowego przygotowania do śmierci była rozwijana przez Wojciecha Chudego pedagogia umierania. Tematyce tej poświęcił odrębny rozdział swojej ostatniej - i jedynej ściśle pedagogicznej - książki ${ }^{11}$.

Zdaniem W. Chudego, osoba ludzka analizowana w tak złożonej i bogatej supozycji, zawiera zawsze pewien element nieprzewidywalności (irracjonalności), co daje asumpt do sprzeciwu wobec wszelkich postaci technologii pedagogicznych. Te ostatnie bowiem ujmują wychowanie w kategorii produktu, którego charakter określają w całości osoby kierujące procesem jego „wytwarzania” i uwarunkowania, w których ten proces przebiega. Złożoność bycia osobowego pociąga za sobą nieostrość odróżnienia kategorii podmiotu od kategorii przedmiotu wychowania. Wychowanek jest bowiem przedmiotem wychowania, będąc zarazem podmiotem samowychowania. Samowychowanie zaś - od strony treściowej - stanowi centrum i cel wszelkich oddziaływań pedagogicznych. Od strony metodologicznej natomiast samowychowanie jest podstawową kategorią personalistycznej filozofii wychowania.

Trzeba podkreślić, że W. Chudy, przez szczególne rozumienie przedmiotu pedagogiki, zmienił niejako jej naukowy charakter. Dla niego pedagogika, jako postać

kulturową pustynią, prawdziwą ziemią jałową, a zaludniałyby go jednostki obojętne i nudne” (s. 1). Hierarchia wartości „określa ład życia ludzkiego wyznaczony linią: osoba - rodzina - wspólnota (społeczność) - Kościół - Bóg” (s. 18).

${ }^{10}$ Por. W. Chudy, Być a stawać się osobą, „Zeszyty Karmelitańskie”, nr 4(29)/2004, s. 30-36; tenże, Prawda człowieka i prawda o człowieku, [w:] K. Popielski (red.), Człowiek - wartości - sens. Studia z psychologii egzystencji: logoteoria i nooteoria: logoterapia i nooterapia, RW KUL, Lublin 1996, s. 146-147.

${ }^{11}$ Zob. tenże, Pedagogia godności... 
wiedzy o wychowaniu, jest nie tylko i nie tyle nauką - która zwykle dąży do jakiegoś systemowego ujęcia (sam zresztą nigdy nie określał swojej filozofii wychowania w kategoriach systemu) - co sztuką ${ }^{12}$. Warto dopowiedzieć, że tezę tę "zapożyczył” od Marka Dyżewskiego, pedagoga i filozofa sztuki, którego „miniwykłady” O trudnej sztuce uczenia sztuki były dla Wojciecha Chudego ważną inspiracją w rozwoju refleksji nad dialogicznymi aspektami filozofii wychowania ${ }^{13}$. To metodologiczne przesunięcie pozwoliło mu jednocześnie uczynić z personalizmu (jako koncepcji człowieka) koncepcję wychowania. Koncepcja ta nie zawiera prostych recept i odpowiedzi na pytanie „jak wychowywać?”, ale przez swoje szczególne podejście do osoby ludzkiej i jej rozwoju pozwala na takie określenie wychowania, którego podstawowym elementem jest s a m o z r o z u m i e n i e o s o b y. Według W. Chudego, doświadczenie i poznanie osoby w sobie samym jest warunkiem zrozumienia charakteru i kierunku własnego rozwoju, ale przede wszystkim katalizatorem samowychowania. Zrozumieć osobę, „tylko tyle i aż tyle” - zwykł mawiać swoim uczniom i studentom.

Stwierdzenie powyższe, będące jedną z podstawowych tez jego filozofii wychowania, ma swoje korzenie we wcześniejszych etapach jego pracy naukowej, zwłaszcza w jego filozofii refleksji. Na długo przed objęciem kierownictwa Katedry Filozofii Wychowania zwracał uwagę na potrzebę

[...] wychowania refleksji. Wychowania przede wszystkim przez poznanie. Auto-poznanie. Rozpoznanie prawdy o sobie „od wewnątrz”, w dynamicznej refleksji niezatopionej we własnej wewnętrzności, lecz ciągle nadążającej za stałą w człowieku tendencją do transcendowania siebie, jest zarazem „związaniem siebie” wewnątrz „poznaną prawdą”. Wychowanie własnej refleksyjności stanowi jednocześnie wychowanie siebie - człowieka ${ }^{14}$.

${ }^{12} \mathrm{Z}$ tym związane może być jego użycie terminu „pedagogika” również w odniesieniu do działalności pedagogicznej, którą w języku pedagogicznym określa się zwykle jako „pedagogię”, tj. praktyczną sztukę wychowania. Podobny wniosek, powołując się jednak na inne przesłanki, wysunął hiszpański filozof M. Maresca. Twierdził on, że „[...] pedagogika jest nauką filozoficzną i może istnieć samodzielnie tylko jako sztuka, a nie teoria”. „Z uwagi na fakt, że uważał pedagogikę za »naukę filozoficzną w całej rozciągłości problemów, którymi się zajmuje«, proponował konsekwentnie zastąpić termin "pedagogika " mianem »filozofii wychowania«" (K. Jakubiak, R. Leppert, Sposoby rozumienia "filozofii wychowania" w polskiej pedagogice XIX i XX wieku, [w:] S. Sztobryn, B. Śliwerski (red.), Idee pedagogiki filozoficznej, Wydawnictwo UŁ, Łódź 2003, s. 226; oraz M. Maresca, La pedagogia sta de se?, La Voce, Roma 1920 i Z. Kukulski, Główne momenty myśli i badań pedagogicznych, Uniwersytet Lubelski, Lublin 1923, s. 113-116, za: K. Jakubiak, R. Leppert, dz. cyt., s. 226).

${ }_{13}$ Por. W. Chudy, Pedagogia godności..., s. 218 nn. oraz O trudnej sztuce uczenia sztuki. Małgorzata Pęcińska rozmawia z Markiem Dyżewskim, cykl audycji II programu Polskiego Radia, emitowanych w piątki od października 2004 do lutego 2005 r.

${ }^{14}$ W. Chudy, Rola refleksji w osobowym spetnianiu się człowieka, „Ethos”, nr 2-3/1988, s. 77. 


\section{Kontekst historiozoficzny}

Wojciech Chudy podkreślał znaczenie filozofii, a zwłaszcza jej historii, w rozwoju myśli pedagogicznej. Uważał, że znajomość podstawowych problemów filozoficznych i właściwa ich interpretacja pozwala pedagogom zrozumieć i ocenić obecną immanentnie w każdej koncepcji wychowania określoną wizję człowieka, jego miejsca i roli w świecie oraz stawianych przed nim, określających zarazem jego rozwój, zadań. W historii filozofii, zdaniem Chudego, można wskazać na trzy etapy istotne dla rozwoju myśli o człowieku. E t a p m e taf i z y c z n y charakteryzuje się opisem człowieka przez pryzmat bytu. W ujęciu metafizycznym człowiek jest bytem, czyli określoną treścią związaną z aktem egzystencji. Można go zatem nazwać „istniejącym czymś”, a raczej „istniejącym kimś”. Podejście to

[...] zapewnia filozofii człowieka obiektywność, pozwalającą na odróżnienie go jako bytu od innych gatunków bytowych (rzeczy, zwierząt itd.), usytuowanie go w hierarchii bytowej, wreszcie na określenie go w perspektywie ładu całego świata, mnogości wszystkich bytów ${ }^{15}$.

W pewnym momencie rozwoju myśli filozoficzno-antropologicznej, jak pisze w Pedagogii godności, taki sposób postrzegania człowieka już nie wystarczał. Metafizyka, ujmująca człowieka jako obiectum, zaczęła być wypierana przez prądy myślowe dowartościowujące jego subiektywność. Ów przełom, związany z Kartezjańskim cogito, zmienił perspektywę myślenia filozoficznego i dał asumpt do rozwoju kolejnego etapu refleksji antropologicznej - fil o z of i i n o w o ży t n e j, wyznaczającej nowe pytania o istotę człowieka (o przeżycia, świadomość i myślenie ludzkie). Od Kartezjusza człowiek ujmowany jako subiectum stał się nie tylko podstawowym przedmiotem dociekań filozoficznych, ale i podstawą samej filozofii. Subiektywność rozumiana jako warunek podmiotowości, odróżniając go tym samym od innych bytów, zajęła miejsce istnienia. Zmieniło się w związku z tym podstawowe pytanie filozoficzne stawiane pod adresem człowieka.

W epoce metafizycznej pytano: „Jakim bytem jest człowiek i dlaczego istnieje?”, „Jakim bytem ja jestem?”. Obecnie zaczęto pytać o przeżycia, świadomość i myślenie ludzkie. „Co przeżywam w relacjach ze światem?”, „Co przeżywam w relacjach z innymi ludźmi?”, „Jaka jest moja wewnętrzna samoświadomość?”, wreszcie: „Kim jestem jako res cogitans?”. Od tego ostatniego pytania było już blisko do kluczowego pytania trzeciego etapu podejścia filozoficznego do człowieka: „Kim jestem?”16.

Według Wojciecha Chudego, trzecim etapem filozoficznego namysłu nad człowiekiem jest e t a p p e r s o n a l is t y c z n y, w którym człowiek ujmowany jest jako osoba, czyli byt wyróżniający się spośród innych istot doczesnych nie tylko ro-

\footnotetext{
15 Tamże, s. 12.

16 Tamże, s. 13.
} 
zumnością i wolą, ale przede wszystkim niepowtarzalną wartością, określaną w filozofii terminem "godność”. W tym ostatnim dopiero, jak pisze, za sprawą m.in. J. Maritaina, E. Mouniera, M. Nédoncelle’a czy K. Wojtyły, człowiek został określony jako ktoś, kto przekracza i transcenduje swoje akty i ich treść - dążąc do czegoś innego niż on sam i świat otaczający, ostatecznie zaś do nawiązania relacji z Bogiem ${ }^{17}$. Chociaż Wojciech Chudy dostrzegał walory zarówno metafizycznego, jak i pozostającego niejako w opozycji do niego nowożytnego podejścia do filozofii człowieka, to personalizm stał się dla niego podstawą filozofii wychowania, natomiast szczególna odmiana myślenia o osobie - personalizm etyczny - podstawą jego etyki pedagogicznej.

Trzeba w tym miejscu dopowiedzieć, że personalizm etyczny jako koncepcja, której twórcami są K. Wojtyła i T. Styczeń, nie tylko przenika i nadaje określony charakter myśli pedagogicznej Wojciecha Chudego, ale również całej jego filozofii. Należy podkreślić rolę metafizyki w rozwoju tej koncepcji. Jej autor, jako uczeń zarówno M. Krąpca, jak i T. Stycznia, łączy bowiem ściśle metafizyczne „jest” człowieka z jego etycznym „stawaniem się" jako osoby, co ma określone konsekwencje pedagogiczne ${ }^{18}$.

W artykule Oblicza personalizmu i ich konsekwencje Wojciech Chudy ukazał trzy odmiany myślenia o człowieku jako osobie i wypływające z nich istotne dla wychowania implikacje ${ }^{19}$. Są to: p e r s o n a l i z m m e t a f i z y c z n y, w którym osoba charakteryzowana jest niejako z zewnątrz, jako byt o pewnym szczególnym charakterze odznaczający się m.in. godnością; p e r s o n a li z m l i b e r a lis t y c z n y, w którym podkreśla się m.in. wolność osoby w stosunku do innych określających ją wartości. W podejściu metafizycznym człowiek jest osobą, w podejściu liberalistycznym osobą się staje. P e r s o nalizm e ty c z ny od strony metodologicznej Wojciech Chudy określał jako modyfikację personalizmu metafizycznego (włączanie elementu refleksyjnego) lub personalizmu liberalistycznego (wyakcentowanie roli prawdy). Tym, co charakterystyczne dla owej modyfikacji, jest swoista synteza metodologiczna filozofii klasycznej (nastawienia przedmiotowego, prymatu bytowego) z „odkryciem subiektywności”. W tym typie myślenia o człowieku mówi się o m o r a 1 n y m z n a c z e n i u osoby ludzkiej. Osoba ludzka to ktoś dany i zadany normatywnie. Stąd ważne dla jej istnienia jest to, czy będzie się w swoich czynach budować, czy degradować, czy będzie w sobie rozwijać wrodzoną wartość godności, czy też będzie ją deprecjonować. Decydującą rolę w procesie wzrostu lub pomniejszania siebie jako osoby odgrywa wartość g o d n o ś c i o s o b o w e j. Ta niezmienna wartość przysługująca osobie jako osobie stanowi normę moralności, kryterium wszystkich ludzkich czynów.

17 Zob. tamże, s. 9-10.

18 Por. tenże, Być a stawać się osoba, s. 30-36.

19 Por. tenże, Oblicza personalizmu i ich konsekwencje, „Kwartalnik Filozoficzny”, nr 3/1998, s. $63-81$. 


\section{Osoba i wychowanie w ujęciu Wojciecha Chudego}

Wydaje się, że tytułowa filozofia wychowania w pewnym stopniu bliska jest zakresowo filozofii edukacji. Bliskość tę wyznacza głównie jej związek z praktyką wychowawczą, którą Wojciech Chudy uważał za domenę aktywności każdego człowieka. Ścisłe związanie uprawianej myśli z praktyką widoczne jest zresztą nie tylko w jego tekstach, ale również w działalności dydaktycznej i popularyzatorskiej. Wojciech Chudy był znany ze swoich licznych wystąpień na konferencjach dla nauczycieli i wychowawców, podczas których w sposób niezwykle przystępny dla środowiska nieobeznanego z filozofią, obrazowo wyjaśniał problem prawdy człowieka i prawdy o człowieku, problem podstawowych rozróżnień (jest to jedna z kluczowych kwestii jego filozofii wychowania) między edukacją, kształceniem i wychowaniem, a przede wszystkim problem godności jako podstawy wszelkiej personalnych odniesień międzyludzkich i problem samowychowania, które ogniskuje wszystkie czynności wychowawcze.

Wychowanie, jak podkreślał, to sprawa doniosła. W swoich tekstach i wykładach ukazywał je jako rzeczywistość przenikającą życie każdego człowieka. Wiedza filozoficzna służyła mu do tego, by wyjaśniać tę rzeczywistość jako immanentną i konieczną zarazem dla objawienia oraz rozwoju osoby w człowieku. Podkreślał, że choć każdy człowiek rodzi się osobą i do chwili śmierci nią pozostaje, jednocześnie nie zawsze osobę w ciągu swego życia unaocznia i nie zawsze rozwija. Dzieje się tak, ponieważ bycie osobą nie jest jednoznaczne z jej stawaniem się, choć owo stawanie się implikuje. Bycie osobą jest bowiem specyficznym, bo wymagającym istnieniem, zakorzenionym w godności osobowej (wartości ontycznej i etycznej zarazem). Godność osobowa łączy porządek metafizyczny z egzystencjalnym. Odkrycie tej szczególnej wartości domaga się jej afirmacji. Ta zaś w sensie ścisłym dokonuje się tylko w wymiarze moralnym.

Godność osobowa jest również przedmiotem i wyrazem prawdziwej m ą d r o ś c i. Spośród wartości osobowych godność jest najmniej uchwytna w płaszczyźnie antropologicznej oraz najmniej potrzebna, najmniej utylitarna, w domenie działalności praktycznej. Jej odkrycie ma jednak przełomowe znaczenie dla rozwoju osobowego człowieka. Godność odkryta (własna lub drugiego człowieka), zdaniem Wojciecha Chudego, nie tylko domaga się afirmacji, ale sama „eksploduje” w człowieku mądrością i dobrocią.

Godność jest też podstawą rozróżnienia przez niego trzech podstawowych kategorii pedagogicznych: edukacji, kształcenia i wychowania ${ }^{20}$. Dwie pierwsze wiąże on

${ }^{20}$ Specyfika koncepcji Wojciecha Chudego wiąże się z tym, że jej treści zakorzenione są przede wszystkim w refleksji filozoficznej i doświadczeniu. Nie mają natomiast systematycznego osadzenia w myśli pedagogicznej. Stąd też jego rozumienie podstawowych terminów pedagogiki, do jakich należą: wychowanie, edukacja czy kształcenie, nieco odbiega od ich uznanych interpretacji pedagogicznych. Tak na przykład, w ujęciu Z. Kwiecińskiego czy T. Hejnickiej-Bezwińskiej „edukacja” jest 
z szerokim rozumieniem wychowania. E d u k a c j a, odnosząca się do zdobywania wiedzy (teoretycznej bądź praktycznej), jest przekazem i nabywaniem określonych treści lub umiejętności. Pojęcie to, jego zdaniem, nie odnosi się jednak bezpośrednio do godności osoby. Ktoś może bowiem mieć ogromny zasób wiedzy, charakteryzować się nieprzeciętną erudycją, a przy tym być człowiekiem złym, bezwzględnym, nieliczącym się ze światem i drugim człowiekiem. K s z t a ł c e n i e, choć odnosi się do formowania człowieka w szerszym sensie niż edukacja, również nie ma bezpośredniego związku ze sferą godnościową. Pojęcie kształcenia Wojciech Chudy wiązał z niemieckim bildung, „budowaniem”, kształtowaniem drugiego według ściśle określonych zasad. Celem tej działalności pedagogicznej jest, według niego, wyposażenie człowieka w pewne umiejętności, nauczenie go określonych sposobów zachowania, np. komunikatywności i grzeczności. Jednakże tu również nie trudno o przykłady wskazujące, że takie rozumienie wychowania człowieka nie zawsze sprzyja „obudzeniu” w nim tego, co rzeczywiście dobre. W odróżnieniu od płaszczyzny kształcenia i edukacji w y ch o w a n i e opiera się na doświadczeniu godności człowieka i jej afirmacji ${ }^{21}$. Wiedza o wychowaniu w sensie ścisłym - personalistycznym - nie jest wiedzą dotyczącą sposobów działania. Jak mawiał do swoich studentów - tylko sofiści twierdzili, że wszystkiego można nauczyć. Personalizm, jak pokazywał, sprzeciwia się temu. Celem wychowania w sensie wąskim nie jest mądrość wyuczalna, przekazywana i przyswajana metodycznie, lecz mądrość sapiencjalna, będąca skutkiem odkrycia godności osobowej. Mądrość ta polega na zdolności odkrywania tego, co ważne w człowieku, i postępowania zgodnie z tym szczególnym poznaniem. Przenosząc tę tezę na grunt pedagogiki, Wojciech Chudy mówił, że podobnie rzecz ma się z wychow(-yw)aniem, którego nie można nikogo nauczyć (nie każdy absolwent pedagogiki będzie dobrym wychowawcą), jak i samowychowaniem. Twierdził, że jedno i drugie może się dokonać jedynie na drodze samodzielnego wysiłku.

Zadaniem wychowawcy jest bowiem nie tyle informowanie, kształtowanie czy urabianie, co unaocznianie i naprowadzanie wychowanka na doświadczenie godności osobowej. Godności samej w sobie zobaczyć nie można, można jej jednak do-

terminem najszerszym z powyższych i odnosi się do ogółu działań, procesów i warunków sprzyjających rozwojowi człowieka we wszystkich aspektach jego życia i działania. Jako taka stanowi proces całościowy, w którym można wyróżnić szereg procesów szczegółowych, a wśród nich m.in. wychowanie i kształcenie. Ujęcie takie ma długą tradycję, wiąże się zresztą z samym źródłosłowem „edukacji” (łac. educatio; od: educare - opiekować się; educere - wychować; lub od: edocere - gruntownie nauczać, wyuczać). Zob. m.in.: T. Hejnicka-Bezwińska, Pedagogika ogólna, Wydawnictwa Akademickie i Profesjonalne, Warszawa 2008, s. 35-38; Z. Kwieciński, Dziesięciościan edukacji (składniki i aspekty - potrzeba całościowego ujęcia), [w:] T. Jaworska, R. Leppert (red.), Wprowadzenie do pedagogiki: wybór tekstów, Oficyna Wydawnicza Impuls, Kraków 1996, s. 31-32.

${ }^{21}$ W. Chudy, Godność człowieka wartością ontyczno-wychowawcza, [w:] M. Kalinowski (red.), Ja-człowiek. Wzrastanie w godności, miłości i miłosierdziu, Wydawnictwo KUL, Fundacja Pomocy Osobom Niepełnosprawnym, Kraków-Lublin 2004, s. 79-83. 
świadczyć i pozwolić doświadczać innym. Doświadczenie to zawsze wiąże się ze spotkaniem i doświadczeniem drugiej osoby i dokonuje się

[...] „po drodze”, „poprzez coś”, na przykład przez wspólne zamieszkanie $\mathrm{z}$ wychowankiem (w domu rodzinnym bądź w internacie lub zakładzie opiekuńczym), poprzez nauczanie określonej wiedzy, poprzez pracę wykonywaną wspólnie [...]. Bez udziału interakcji wychowanie zamienia się w moralizatorstwo, polegające głównie na wygłaszaniu maksym w rodzaju: „trzeba być pracowitym (prawdomównym, punktualnym, rzetelnym)”22.

Dopiero po odkryciu godności pojawiają się powinność i norma działania. Nie mogą one być rezultatem czystego teoretyzowania, błądzenia w świecie idei, ale właśnie doświadczenia, w którym dokonuje się samopoznanie osoby. Wojciech Chudy wskazywał na dwie metody tak rozumianego wychowania. Pierwsza - określana przez niego jako pozytywna, to właśnie owo naprowadzanie na doświadczenie godności. Druga to metoda negatywna, polegająca na ukazywaniu pozorności niektórych wartości osobowych (urody, sprawności, wykształcenia, tytułów). Wojciech Chudy zwykł podkreślać, że godność jest różna od uposażenia. Człowiek j e s t k i m ś osobą, poza tym m a c oś - „narzędzia” potrzebne do aktualizacji osoby. Na tym fundamentalnym sądzie o człowieku zasadza się jego określenie wychowania, opierające się na rozpoznaniu godności ${ }^{23}$.

Nie jest to poznanie czysto teoretyczne, lecz takie ujęcie wartości osobowej, które pociąga za sobą rodzaj inspiracji do działania. Poznanie godności każe nam coś zrobić, nie pozwala pozostać obojętnym. Pragnienie aktywności, obudzone przez uświadomienie sobie godności osobowej, charakteryzuje się chęcią dawania. [...] reakcją na godność, zarówno swoją, jak i drugiego człowieka, jest miłość w najbardziej fundamentalnym znaczeniu - jako wo la d a w a n i a ${ }^{24}$.

Mądrość, będąca podstawowym celem wychowania w świetle filozofii wychowania Wojciecha Chudego, nie opiera się na wiedzy o przyczynach i zasadach ludzkiego bycia w świecie, jak ma to miejsce w metafizyce. Mądrość nie zamyka się też w wiedzy o tym, „co i jak” być powinno, jak głoszą opcje intelektualistyczne. Mądrość wreszcie, może nieco paradoksalnie, nie sprowadza się do „bycia dobrym”, jako że różne mogą być racje działania ludzkiego, niekonieczne wypływające $z$ afirmacji osoby dla niej samej. Mądrość prawdziwa opiera się na doświadczeniu i afirmacji godności osobowej. I chociaż wartość tę trudno poznać teoretycznie, niełatwo ją zdefiniować i zrozumieć w oparciu o wiedzę naukową, można ją poznać praktycznie, w dostępnym każdemu akcie afirmacji osoby swojej i drugiego człowieka.

${ }^{22}$ Tenże, Istota pedagogiki personalistycznej, s. 52; por. tenże, Godność człowieka wartościa ontyczno-wychowawcza, s. 81-83.

${ }^{23}$ Zob. tenże, Personalistyczne określenie wychowania, s. 92-93.

${ }^{24}$ Tamże, s. 93. 
Wychowanie to przestrzeń pracy nad samym sobą, ale pracy, która dokonać się może tylko za sprawą drugiego człowieka, przez spotkanie i dialog. Nauczając innych, o czym życiem i pracą świadczył Wojciech Chudy, nauczamy i uczymy się samych siebie. Prawdziwe wychowanie jest bowiem zawsze współwychowywaniem osoby.

\section{Zakończenie}

Zaprezentowany zarys filozofii wychowania Wojciecha Chudego stanowi jedynie próbę przybliżenia - zwłaszcza pedagogom - jego koncepcji. Wydaje się, że myśl ta, wciąż jeszcze szerzej znana głównie w środowisku związanym ze szkołą skupioną wokół jego seminarium doktorskiego, stanowi wartościowy wkład do dorobku polskiej filozofii wychowania. Oryginalność tej koncepcji, ale zarazem brak rozpoznawalności wiążą się z faktem, że powstawała niejako na uboczu myśli pedagogicznej. Wojciech Chudy bowiem nie tylko nie angażował się w aktualne dyskusje pedagogiczne, lecz również nie dążył do stworzenia systemu filozofii wychowania (ani tym bardziej do zapisania odrębnej karty w historii myśli pedagogicznej). Śledząc rozwój jego myśli teoriopoznawczej, później antropologicznej, w końcu etycznej i pedagogicznej, jak też zaangażowanie społeczne i teksty publicystyczne, można zauważyć stopniowe, lecz konsekwentne przybliżanie się Autora do problematyki rozwoju człowieka, zwłaszcza w aspekcie moralnym. Dlatego Wojciech Chudy tak mocno związał swoją filozofię wychowania z etyką, a pedagogikę ze sztuką rozumienia i wychowania człowieka. Mimo pewnych formalnych podobieństw do znanych koncepcji polskiej filozofii wychowania, zaznaczonych jedynie zdawkowo w przypisach przeprowadzonych rozważań, dorobek Wojciecha Chudego stanowi oryginalne i domagające się dalszych studiów oraz rozwijania źródło wiedzy pedagogicznej.

\section{Bibliografia}

Bronk A., Pedagogika i filozofia: uwagi metafilozoficzne, [w:] P. Dehnel, P. Gutowski (red.), Filozofia a pedagogika. Studia i szkice, Wydawnictwo Naukowe Dolnośląskiej Szkoły Wyższej Edukacji TWP we Wrocławiu, Wrocław 2005.

Chudy W., Być a stawać się osobą, „Zeszyty Karmelitańskie”, nr 4/2004.

Chudy W., Filozofia wieczysta w czas przełomu. Gdańskie wykłady z filozofii klasycznej z roku 1981, TN KUL, Lublin 2008.

Chudy W., Godność człowieka wartościa ontyczno-wychowawczą, [w:] M. Kalinowski (red.), Ja-człowiek. Wzrastanie w godności, miłości i miłosierdziu, Wydawnictwo KUL, Fundacja Pomocy Osobom Niepełnosprawnym, Kraków-Lublin 2004. 
Chudy W., Jan Pawet II - nauczyciel kultury. Osoba ludzka znakiem trudu i nadziei, [w:] Osobowy wymiar kultury. Materiaty XV Ogólnopolskiego Forum Szkót Katolickich, Redakcja Szkół Katolickich, Warszawa 2004.

Chudy W., Między Werterem a Stawroginem - albo wartości w życiu człowieka, maszynopis w posiadaniu autorki.

Chudy W., Oblicza personalizmu iich konsekwencje, „Kwartalnik Filozoficzny”, nr 3/1998, s. 63-81.

Chudy W., Odchodzenie z nadzieja. U podstaw pedagogiki umierania, [w:] K. Mielcarek (red.), Dar i tajemnica śmierci. Tydzień eklezjologiczny 2006. W trosce o Kościót, t. VII, Polihymnia, Lublin 2007.

Chudy W., Pedagogia godności. Elementy etyki pedagogicznej, TN KUL, Lublin 2009.

Chudy W., Personalistyczne określenie wychowania, [w:] P. Jaroszyński, P. Tarasiewicz, I. Chłodna (red.), Filozofia i edukacja. Materiaty z sympozjum z cyklu „Przyszłość cywilizacji zachodu” zorganizowanego przez Katedrę Filozofii Kultury KUL, Fundacja „Lubelska Szkoła Filozofii Chrześcijańskiej”, Lublin 2005.

Chudy W., Prawda człowieka i prawda o człowieku, [w:] K. Popielski (red.), Człowiek wartości - sens. Studia z psychologii egzystencji: logoteoria i nooteoria: logoterapia i nooterapia, RW KUL, Lublin 1996.

Chudy W., Rola refleksji w osobowym spetnianiu się człowieka, „Ethos”, nr 2-3/1988.

Hejnicka-Bezwińska T., Pedagogika ogólna, Wydawnictwa Akademickie i Profesjonalne, Warszawa 2008.

Jakubiak K., Leppert R., Sposoby rozumienia ", filozofii wychowania" w polskiej pedagogice XIX i XX wieku, [w:] S. Sztobryn, B. Śliwerski (red.), Idee pedagogiki filozoficznej, Wydawnictwo UŁ, Łódź 2003.

Jaworska-Witkowska M., Witkowski L., Pedagogika filozoficzna: relacje między pedagogika, filozofiq i humanistyka a edukacja, kultura i życiem społecznym, [w:] B. Śliwerski (red.), Pedagogika. Subdyscypliny i dziedziny wiedzy o wychowaniu, GWP, Gdańsk 2010.

Kukulski Z., Główne momenty myśli i badań pedagogicznych, Uniwersytet Lubelski, Lublin 1923.

Kwieciński Z., Dziesięciościan edukacji (składniki i aspekty - potrzeba całościowego ujęcia), [w:] T. Jaworska, R. Leppert (red.), Wprowadzenie do pedagogiki: wybór tekstów, Oficyna Wydawnicza Impuls, Kraków 1996.

Lekka-Kowalik A., Filozofia edukacji i edukacja filozoficzna - antidotum na kryzys?, [w:] P. Jaroszyński, P. Tarasiewicz, I. Chłodna (red.), Filozofia i edukacja. Materiały z sympozjum z cyklu „Przyszłość cywilizacji Zachodu”, zorganizowanego przez Katedrę Filozofii Kultury, Fundacja „Lubelska Szkoła Filozofii Chrześcijańskiej", Lublin 2005.

Maresca M., La pedagogia sta de se?, La Voce, Roma 1920.

O trudnej sztuce uczenia sztuki. Małgorzata Pęcińska rozmawia z Markiem Dyżewskim, cykl audycji II programu Polskiego Radia, emitowanych w piątki od października 2004 do lutego $2005 \mathrm{r}$. 
Smołka E., Profesor i nauczyciel, „Ethos”, nr 79-80/2007.

Sztobryn S., Filozofia wychowania $w$ Polsce $w$ XX wieku. Zarys problematyki, „Medodiczni Studii. Zbirnik Naukowo-Metodicznich Prac”, Wipusk 2, Donieck 2012.

Sztobryn S., Pedagogika i filozofia - wzajemne relacje. Stanowisko pedagogów okresu międzywojennego $w$ świetle literatury czasopiśmiennej, „Colloquia Communia”, nr 2/2003.

Witkowski L., Między pedagogika, filozofia i kulturą. Studia, eseje, szkice, t. 3, Instytut Badań Edukacyjnych, Warszawa 2007.

\section{Wojciech Chudy's Philosophy of Education}

Abstract: Wojciech Chudy's philosophy of education is based on a personalistic theory. Thus, Chudy treats a person as a constant entity and a dynamic phenomenon. It means that each human being is interpreted as someone who both is, and becomes, a person throughout his or her entire life. Personal dynamism concerns morality. Therefore, according to Chudy's stance, education is primarily self-education and it occurs when a person encounters another person.

Keywords: Wojciech Chudy, philosophy of the person, dignity of the person, education, self-education

About the author: Anna Szudra-Barszcz - Ph.D. in the field of education; M.Phil.; place of work: Institute of Education, Department of Comparative Pedagogy and Philosophy of Education, the John Paul II Catholic University of Lublin; research fields and topics: philosophy of education, educational ethics, ethical aspects of special education. 


\title{
Przygotowanie do dorosłości jako cel wychowania rodzinnego
}

DOI: 10.25312/2083-2923.15/2019_15ez

\begin{abstract}
Streszczenie: W artykule, na bazie wyników własnych badań o charakterze jakościowym, podjęto zagadnienie przygotowania do dorosłości jako celu wychowania. We wstępie przedstawiono ogólne refleksje na temat wychowania rodzinnego oraz sformułowano cel rozważań. Trzy zasadnicze części tekstu dotyczą kolejno: przygotowania do dorosłości na tle rodzicielskiej świadomości teleologicznej, obrazu dorosłości wpisanego w cele wychowania ukierunkowane na przygotowanie do niej oraz kompetencji człowieka dorosłego znajdujących odzwierciedlenie w celach wychowania ukierunkowanych na przygotowanie do dorosłości. W zakończeniu przedstawione zostały wnioski dotyczące zupełności rodzicielskich obrazów dorosłości oraz treści analizowanych celów, a także roli dzieci w tak ujmowanym wychowaniu.
\end{abstract}

Słowa kluczowe: cele wychowania, przygotowanie do dorosłości, teleologia wychowania, wychowanie, wychowanie rodzinne

\section{Wstęp}

Asumptem do podjęcia tematyki przygotowania do dorosłości jako celu wychowania rodzinnego były wyniki badań prowadzonych w ramach rozprawy doktorskiej na temat celów wychowania w rodzinach o różnym poziomie wykształcenia rodziców. Wskazywały one wyraźnie na ważne miejsce powyższego dążenia w systemie rodzicielskiej świadomości teleologicznej. Tendencja ta występowała niezależnie od poziomu wykształcenia, którym legitymowali się rodzice.

Edyta Zawadzka - doktor nauk społecznych w zakresie pedagogiki, adiunkt w Akademii Pedagogiki Specjalnej im. Marii Grzegorzewskiej w Warszawie. Zainteresowania naukowe: teleologia wychowania, pedagogizacja życia codziennego. 
W kontekście tematyki niniejszego artykułu możliwe jest przypisanie rodzinie dwojakiego znaczenia ${ }^{1}$. Po pierwsze, jawi się ona jako pewien kontekst życia i socjalizacji człowieka. Po drugie, jest przestrzenią, w której miejsce ma świadome i ukierunkowane na określone cele wychowanie. Te dwa wymiary rodziny konstytuują ją jako środowisko, które ma niebagatelny wpływ na procesy rozwoju, a także kształt dorosłości człowieka. I tak członkowie rodziny nie tylko uczestniczą w procesach kształtowania osobowości dzieci/młodzieży, warunkują ich postawy wobec innych, pomagają urzeczywistniać człowieczeństwo i tkwiący w nich potencjał, budować i klaryfikować system wartości, ale również nadają określony status czy wyposażają w pewne schematy umożliwiające interpretację świata, jego zrozumienie czy ustosunkowanie się do informacji z niego płynących ${ }^{2}$. W ten sposób rodzina zarówno świadomie, jak i nieświadomie przygotowuje dzieci do funkcjonowania w dorosłości. Przedmiotem rozważań w niniejszym tekście są te aspekty wspomnianego odziaływania, które mają charakter intencjonalny i znajdują odzwierciedlenie w celach wychowania. Jednocześnie jednak świadomość teleologiczna rodziców jako złożony konstrukt pozostaje w związkach z wieloma innymi czynnikami powiązanymi z drugim wymiarem jej funkcjonowania.

Niniejszy artykuł nie ma charakteru normatywnego, nie odpowiada zatem na pytanie o najlepszą koncepcję wychowania czy o cele, na jakie ma być ono ukierunkowane, by przygotować do analizowanej fazy życia. Jakościowy charakter badań ${ }^{3}$ stanowiących podstawę treści artykułu nie pozwala również na generalizację sformułowanych w niniejszym artykule wniosków czy ich porównywanie z innymi badaniami. Jednakże specyfika eksploracji prowadzonych z zastosowaniem wspomnianej strategii badawczej stwarza wartościową perspektywę dla rozpoznania i scharakteryzowania sensów i wartości wpisanych w przygotowanie do dorosłości/funkcjonowania w dorosłości jako jeden z ważniejszych i powszechniejszych celów wychowania.

${ }^{1}$ Por. J. Kułaczkowski, Cechy rodziny jako środowiska wychowawczego, [w:] J. Kułaczkowski (red.), Leksykon pedagogiki rodziny, Bonus Liber. Wydawnictwo i Drukarnia Diecezji Rzeszowskiej, Warszawa 2011, s. 36.

2 Por. M. Bereźnicka, Wychowanie dziecka we współczesnej rodzinie, Wydawnictwo Naukowe Uniwersytetu Pedagogicznego, Kraków 2014, s. 124-126; B. Czeredrecka, Rodzina jako środowisko życia i wychowania, [w:] U. Gruca-Miąsik (red.), Dziecko i rodzina. Społeczne powinności opieki i wychowania, WUR, Rzeszów 2007, s. 12; M. Farnicka, Przemiany realizacji zadań rozwojowych. Ewolucja czy rewolucja?, Uniwersytet Zielonogórski, Zielona Góra 2011, s. 37; A. Kamiński, Funkcje pedagogiki społecznej: praca socjalna i kulturalna, Państwowe Wydawnictwo Naukowe, Warszawa 1980, s. 101; B. Kiereś, Rodzina jako miejsce kształtowania charakteru człowieka, „Cywilizacja”, $\mathrm{nr}$ 6/2008, s. 86-92; U. Kozubowska, Rodzina jako najważniejsza przestrzeń kształtowania się systemu wartości i tożsamości dziecka, [w:] W. Muszyński (red.), Wartości w rodzinie: ciagłość i zmiana, Wydawnictwo Adam Marszałek, Toruń 2010, s. 45.

${ }^{3}$ Badania te prowadzone były $\mathrm{z}$ zastosowaniem metody zbiorowego studium indywidualnych przypadków oraz techniki pogłębionego wywiadu z obojgiem rodziców. Wzięły w nich udział 92 rodziny cechujące się różnym poziomem wykształcenia, posiadające dzieci, których wiek mieścił się w przedziale 0-12 lat. Analizując pozyskane dane, zaimplementowano podejście nomotetyczne $\mathrm{z}$ elementami idiograficznego. 


\section{Przygotowanie do dorosłości na tle świadomości teleologicznej rodziców}

Świadomość teleologiczna stanowi jeden z komponentów świadomości wychowawczej rodziców $w^{4}$. W badaniach własnych charakteryzowano ją poprzez odniesienie się do dwóch zagadnień - umiejętności werbalizacji celów wychowania oraz rozumienia ich znaczenia $w$ realizowanym procesie wychowania rodzinnego ${ }^{5}$. Wbrew rozpowszechnionemu w polskim dyskursie naukowym poglądowi dotyczącemu braku czy trudności w werbalizacji celów wychowania ${ }^{6}$ w znakomitej większości rodzin (81) rodzice potrafili odpowiedzieć na pytanie o to, co chcieliby osiągnąć/ku czemu dążą, wychowując swoje dzieci ${ }^{7}$.

Przygotowanie do dorosłości uznać należy za ważny komponent świadomości teleologicznej rodziców. Analizując bowiem treść wypowiedzi respondentów, należy zauważyć, że powszechnie, niezależnie od poziomu wykształcenia rodziców, pojawiają się sformułowania wskazujące na częstsze ukierunkowanie formułowanych celów na dorosłość niż na teraźniejszość (dzieciństwo) czy niedaleką przyszłość (adolescencję). Ujmując rzecz dokładniej, odnoszono się do przygotowania do niej, „radzenia sobie" w dorosłym życiu, odgrywania ról przypisanych tej fazie (Polaka, obywatela, pracownika, rodzica, płciowych - kobiety/mężczyzny) czy uniknięcia zagubienia oraz sprostania problemom jej towarzyszącym ${ }^{8}$. Rodzicielski namysł nad celami wychowania nie ograniczał się, co wydaje się oczywiste, tylko do tych sfokusowanych na przy-

${ }^{4}$ Por. E. Świdrak, Świadomość wychowawcza we współczesnej rodzinie, Wydawnictwo KUL, Lublin 2013, s. 43-45.

${ }^{5}$ Wnioski z badań dotyczące zagadnienia uzasadnień istotności celów wychowania podjęłam w innym artykule - E. Zawadzka, Współczesne uzasadnienia celów wychowania rodzinnego w świetle badań nad celami wychowania w rodzinach o zróżnicowanym poziomie wykształcenia rodziców, [w:] D. Opozda, M. Leśniak (red.), Rodzicielstwo w wybranych zagadnieniach pedagogicznych, Episteme, Lublin 2017, s. 53-61.

${ }^{6}$ Por np. B. Suchodolski, Zagadnienia podstawowe, [w:]: B. Suchodolski (red.), Pedagogika. Podręcznik dla kandydatów na nauczycieli, t. 1, Państwowe Wydawnictwo Naukowe, Warszawa 1985, s. 70.

${ }^{7}$ Formułowane przez rodziców cele wychowania cechowały się wysoką heterogenicznością w każdej z grup wyróżnionych ze względu na poziom wykształcenia rodziców, co niemożliwym czyni przedstawienie w niniejszym tekście bez czynienia symplifikacji treści wszystkich celów pojawiających się w refleksji teleologicznej rodziców. Ważne wydaje się jednak wskazanie, że w całościowej ujmowanej próbie badawczej rodzice posiadali dążenia wychowawcze w każdej ze sfer funkcjonowania człowieka, tj. biologicznej, społecznej, kulturowej oraz umysłowo-psychicznej, przy czym najpowszechniej występowały te odnoszące się do dwóch pierwszych, najmniej często takie przynależne obszarowi związanemu z tradycyjnie rozumianą kulturą elitarną (zainteresowania, uczestnictwo w kulturze).

${ }^{8}$ Wnioski te wydają się pozostawać w sprzeczności z wynikami badań D. Opozdy, zgodnie z którymi w jednostkowej wiedzy rodziców na temat wychowania dominowały cele ukierunkowane na rozwój dziecka (emancypację). Jest to jednak sprzeczność pozorna, będąca konsekwencją zarówno złożoności celów ukierunkowanych na dorosłość, jak i odmiennych kategorii pojęciowych i analitycznych zastosowanych w badaniach Opozdy oraz moich. Por. D. Opozda, Struktura i treść 
gotowaniu do dorosłości. Przywoływanie ich w niniejszym artykule nie wydaje się zasadne, chociażby ze względu na ich wielość i złożoność, które wymagają większej uwagi niż jedynie zasygnalizowania. Ich dogłębna analiza skłania jednak do sformułowania wniosku, że nie były one zupełnie odrębne treściowo i niepowiązane z dorosłością. Najbardziej transparentny przykład uzasadniający powyższą tezę odnosi się do, wydaje się abstrakcyjnego i mającego charakter uniwersalny, celu, którego trzon stanowi „bycie dobrym/porządnym człowiekiem” (zarówno w formie celu czynnościowego - „wychowanie (na) dobrego człowieka”, jak i celu marzenia - pragnienie, by dziecko „było dobrym człowiekiem”). Rodzice poproszeni o doprecyzowanie znaczenia użytego sformułowania odnosili się często do takich cech, zachowań czy kompetencji, które nierozerwalnie powiązane są z dorosłością, a nie ogólnie rozumianymi człowieczeństwem czy wartościami uniwersalnymi.

W świetle powyższego zasadne wydaje się skonstatowanie, że w rodzicielską świadomość wychowawczą, a szczególnie w jej komponent teleologiczny, wpisana jest swoista odpowiedzialność za przyszłość dziecka utożsamiana z dorosłością. Poszukując uzasadnień takiego stanu, możliwe jest zaakcentowanie zarówno społecznego postrzegania roli rodzicielskiej, jak i specyfiki samej dorosłości jako etapu przypadającego na znaczną część biografii człowieka.

\section{Obrazy dorosłości wpisane w przygotowanie do dorosłości jako cel wychowania}

Jednym z najważniejszych wymiarów świadomości teleologicznej rodziców jest posiadana przez nich wizja dorosłości. Nie tylko znajduje ona odzwierciedlenie w formułowanych celach wychowania, ale również wyznacza kierunki ich działania i jakość wychowania rodzinnego. Przedstawione poniżej jej obrazy cechują się eklektycznością wynikającą nie tylko z różnorodności samych celów do niej się odnoszących, ale również sytuacji życiowych rodziców czy ich poglądów i nastawienia wobec rzeczywistości społecznej i sposobów funkcjonowania w niej człowieka.

Na najbardziej ogólnym poziomie dorosłość, w perspektywie celów wychowania, opisywana jest w opozycji do dzieciństwa, które postrzegane jest jako faza życia człowieka, w której jego funkcjonowanie ma raczej wymiar spontaniczny, niewymagający posiadania specjalnych kompetencji czy ponoszenia odpowiedzialności. Odmiennie dorosłość jawi się jako etap tak złożony i nacechowany wyzwaniami i zadaniami, że efektywne funkcjonowanie w nim wymaga długotrwałego przygotowania mającego miejsce właśnie w poprzedzających ją latach życia. Bazując na refleksjach rodziców dotyczących kresu wychowania jako działalności przebiegającej w dzieciństwie, możliwe jest również podjęcie zagadnienia związanego z początkiem dorosłości. I tak bywa

jednostkowej wiedzy o wychowaniu. Studium pedagogiczne wiedzy rodziców i jej korelatów, Towarzystwo Naukowe KUL-Katolicki Uniwersytet Lubelski Jana Pawła II, Lublin 2012, s. 251-253. 
on rozumiany zgodnie z literą prawa jako wyznaczony przez osiemnaste urodziny, ale również subiektywnie ujmowany przez pryzmat wydarzeń życiowych, np. ukończenia szkoły ponadgimnazjalnej, pozyskania pracy i osiągnięcia niezależności zawodowej, opuszczenia domu rodzinnego czy uświadomienia sobie przez wychowawcę i wychowanka braku zasadności dalszego wychowywania. Wyrażane przez rodziców poglądy dotyczące czynników świadczących o dorosłości warto skonfrontować ze współczesną refleksją naukową na ten temat. I tak P. Oleś wskazuje na następujące jej wskaźniki - określenie kierunku własnego życia, wybór dominującej aktywności i celów w perspektywie 10-20 lat, samookreślenie w zakresie życia w związku lub singlizmu, gotowość do ponoszenia odpowiedzialności, niezależność zarówno emocjonalna, jak i w zakresie autonomicznego podejmowania decyzji, wolność wyboru i determinacja odnosząca się do urzeczywistniania pragnień i dążeń?

Jednym z ważniejszych wariantów dorosłości jest ta będąca wyrazem reprodukcji społecznej, czyli ta pokoleniowo powielana. U jej podstaw sytuuje się założenie, że dzieci wychowujące się w rodzinie cechującej się określonym kapitałem symbolicznym (będącym konsekwencją obecności innych - ekonomicznego, społecznego, kulturowego) „odziedziczą” habitus rodziców oraz ich status społeczny czy, prościej rzecz ujmując, będą wiodły podobne/takie samo życie jak ich matki i ojcowie (a idąc dalej również dziadkowie $)^{10}$. Kształt takiego wariantu dorosłości różnicuje oczywiście status społeczny rodziny ujmowany przez pryzmat wielu jego komponentów związanych, w przypadku moich badań, z poziomem wykształcenia rodziców, powiązanej z nim sytuacji zawodowej oraz materialnej. I tak rodzice o niskim poziomie wykształcenia (najczęściej podstawowym/gimnazjalnym, zasadniczym zawodowym), raczej niezamożni oraz pracujący jako wykwalifikowani lub niewykwalifikowani pracownicy fizyczni lub niepracujący sądzili niekiedy, że ich dzieci czeka taka sama przyszłość. Stawało się to dla nich przesłanką do formułowania celów związanych z nabyciem niezbędnego poziomu wykształcenia, „konkretnego”, zapewniającego zatrudnienie w zawodzie podobnym lub tożsamym z tym wykonywanym przez rodziców. Szczególnie istotne wydaje się jednak spostrzeżenie, że projektowana wizja dorosłości dziecka była punktem wyjścia do nieformułowania pewnych celów dotyczących np. znajomości innych od polskiej kultur jako zbędnych z powodu braku intencji opuszczania ojczyzny czy wartości jako czegoś niepotrzebnego w życiu osób niezamożnych czy niewykształconych. Ponadto była ona uzasadnieniem rezygnacji ze stanowienia celów utożsamianych z uczestnictwem w kulturze czy wyborem zainteresowań, które uznawane były za „stratę czasu”, niepotrzebną aktywność, domenę ludzi bogatych i wykształconych, coś bezsensownego czy niemożliwego do zrozumienia przez ludzi

${ }^{9}$ P. Oleś, Psychologia człowieka dorosłego. Ciągłość - zmiana - integracja, Wydawnictwo Naukowe PWN, Warszawa 2011, s. 18.

${ }_{10}$ P. Bourdieu, Dystynkcja. Społeczna krytyka sądzenia, Wydawnictwo Naukowe Scholar, Warszawa 2005, s. 86; P. Mikiewicz, Kapitał społeczny i edukacja, Wydawnictwo Naukowe PWN, Warszawa 2014, s. 93-107. 
„takich jak oni”. Dla osób cechujących się wysokim poziomem wykształcenia, często zamożniejszych, a przez to niejednokrotnie reprezentujących wyższe klasy społeczne, intencja, by dorosłość wychowanków była tożsama z ich własną, bywała powodem formułowania takich celów, które umożliwiłyby jej spełnienie. Odnosiły się one przykładowo do zapewnienia dzieciom wykształcenia, nauczenia ich kulturalnego zachowania, kształtowania i wspierania zainteresowań, formułowania określonych poglądów lub umiejętności ich wyboru, a także wykształcenia racjonalnych postaw wobec kultury i uczestnictwa w niej. Taki obraz dorosłości nie stanowił argumentu dla pomijania jakichś celów.

Na przeciwległym biegunie sytuuje się dorosłość odmienna od tej doświadczanej przez rodziców. U podstaw celów wychowania, w których znajduje ona odzwierciedlenie, sytuują się marzenia rodziców o awansie społecznym, który miałby stać się udziałem ich dzieci i który współcześnie jest częściej niż dawniej dostępny ${ }^{11}$. Treść takich celów wychowania związana jest z tymi wszystkimi kompetencjami, które w opinii rodziców dziecko powinno nabyć w celu osiągnięcia sukcesu życiowego. Ponadto cele te są wynikiem refleksji rodziców nad własnymi błędami skutkującymi niezadowalającą ich sytuacją i ukierunkowane są na ochronę dziecka przed ich popełnieniem, a przez to umożliwienie mu osiągnięcia lepszego standardu życia.

Inny aspekt dorosłości obecny w świadomości teleologicznej rodziców wiąże się z jej charakteryzowaniem przez pryzmat ról społecznych jej przypisanych. Jedną $\mathrm{z}$ nich jest rola obywatela, która nie ma wymiaru jednorodnego. W zależności bowiem od nastawień rodziców owo obywatelstwo odnosić może się zarówno do Polski, Europy, jak i świata. Sfery celów wychowania, w których najsilniej znajduje odzwierciedlenie nie tylko takie ujęcie dorosłości, ale również kompetencje mu przypisane, to te związane ze społeczną i kulturową sferą egzystencji człowieka. Kolejna rola to pracownik, o którym wspominano w procesie formułowania celów związanych głównie z wykształceniem dzieci i założeniami rodziców względem zawodu wykonywanego przez potomstwo. Analizując antycypowaną przez rodziców aktywność zawodową dzieci, możliwe jest wskazanie przykładów zarówno ścisłego, jak i ogólnego określania jej obszarów poprzez przypisanie różnych cech zawodowi wykonywanemu przez dziecko w przyszłości (np. dobrze płatny, przynoszący satysfakcję). Inna rola powiązana $\mathrm{z}$ rodziną jako grupą związana jest $\mathrm{z}$ członkostwem $\mathrm{w}$ niej. Ponownie nie ma ona wymiaru heterogenicznego, czego implikacją jej wyróżnienie szeregu ról wewnątrz niej (syna/córki, matki/ojca, brata/siostry). Cele wychowania, z których ona wynika, skoncentrowane są zarówno na ukształtowaniu kompetencji dzieci w zakresie intencji podejmowania zadań z nimi związanych, odczuwania odpowiedzialności za rodzinę, właściwej (subiektywnie ujmowanej) ich realizacji czy kontynuowania tradycji rodzinnych. Powiązane zakresowo z powyższą są role płciowe. Jeśli pojawiały

${ }^{11}$ M. Biedroń, Realizacja funkcji rodziny w kontekście globalnych przemian socjokulturowych, [w:] A. Ładyżyński (red.), Rodzina we wspótczesności, Oficyna Wydawnicza Atut, Wrocław 2009, s. 47; A. Giddens, Socjologia, Wydawnictwo Naukowe PWN, Warszawa 2012, s. 322-323. 
się one w refleksjach rodziców, odnosiły się zazwyczaj do przygotowania do pełnienia zadań tradycyjnie, często stereotypowo przypisanych kobietom lub mężczyznom. Cele wychowania rodzinnego są również wyrazem przypisywania dorosłości bardziej abstrakcyjnie rozumianych ról. I tak rodzice deklarowali dążenia związane z wychowaniem "jakiegoś” człowieka, najczęściej dobrego czy „porządnego”. Obrazy dobrego lub „porządnego” człowieka cechują się heterogenicznością i są one kreślone poprzez odniesienie się zarówno do szeregu cech czy postaw ${ }^{12}$, jak również sfer funkcjonowania człowieka (biologicznej, społecznej, kulturowej czy umysłowo-psychicznej). To, co je jednak łączy, to przekonanie, że dziecko nie jest z natury dobre czy „porządne”, a dopiero takie może się stać dzięki odziaływaniom wychowawczym w rodzinie.

Podsumowując, dorosłość w perspektywie celów wychowania jawi się jako stosunkowo trudna, nasycona zadaniami i wyzwaniami faza życia. W samą treść celów wychowania nie wydaje się być wpisana bardziej optymistyczna jej wizja czy pozytywne jej aspekty, a także naturalnie tkwiący w niej potencjał. Nawet samostanowienie czy autonomia człowieka dorosłego ujmowane bywają przez rodziców w kategoriach konieczności czy obowiązku, a nie prawa czy przywileju. Niecałkowicie świadome przekazywanie dzieciom takiej informacji o dorosłości, a także stanowienie i realizacja celów wychowania zorientowanych na przygotowanie do niej przyczyniają się do budowania nieadekwatnych postaw wobec niej wśród dzieci i młodzieży. Takie zafałszowane jej rozumienie wpływa zatem nie tylko na ich indywidualnie ujmowaną przyszłość, ale również na kształt społeczeństwa ${ }^{13}$.

\section{Kompetencje jako cele wychowania ukierunkowane na przygotowanie do dorosłości}

Opisane w poprzedniej części wizje dorosłości wydają się stanowić racjonalną przesłankę dla przejawianego przez rodziców przekonania, że warunkiem adekwatnego i efektywnego funkcjonowania człowieka dorosłego oraz sprostania zadaniom rozwojowym związanym $\mathrm{z}$ analizowaną fazą życia jest posiadanie przez niego szeregu kompetencji (wiedzy, umiejętności, postaw) będących efektem wychowania rodzinnego. Wydaje się, że takie poglądy odzwierciedlają opisane przez M. Nowaka ${ }^{14}$ przejście od pedagogiki celów do pedagogiki kompetencji, o idei której decyduje uczynie-

${ }^{12}$ W sposób bardziej drobiazgowy opisane zostaną one w następnej części.

13 Por. A. Frindt, Czy warto być dorosłym? Społeczno-kulturowe uwarunkowania pojęcia dorosłości w świadomości młodzieży wielkomiejskiej, Wydawnictwo Akademickie Żak, Warszawa 2005, s. 10 .

14 M. Nowak, Od pedagogiki celów do pedagogiki zadań i kompetencji, [w:] E. Ogrodzka-Mazur, A. Szczurek-Boruta (red.), Poza paradygmaty. Pedagogika wielostronna. Ksiega pamiątkowa dedykowana profesorowi Tadeuszowi Lewowickiemu, t. 1, Wydawnictwo Adam Marszałek, Toruń 2012, s. 409,422 . 
nie procesu wychowania i kształcenia mniej adaptacyjnym i ukierunkowanie go na przygotowanie do rozwiązywania problemów.

Najpowszechniejszym obszarem wiedzy możliwym do zidentyfikowania w celach wychowania ukierunkowanych na przygotowanie do dorosłości jest ten odnoszący się do znajomości zasad związanych z funkcjonowaniem w społeczeństwie, przestrzeganiem prawa, dekalogiem, sposobami realizacji własnych celów i obowiązków, motywami postępowania oraz relacjami z innymi osobami. Dzięki nim synowie i córki mieli w przyszłości właściwie pełnić funkcje społeczne, osiągnąć szczęście, uniknąć problemów czy też urzeczywistnić ideał wychowania związany ze staniem się dobrym człowiekiem.

Kolejny obszar wiedzy odnosi się do bazujących na niej poglądach, które w okresie dzieciństwa miały zostać nabyte, a w przyszłości urzeczywistniane. Ich przedmiot jest złożony i związany z człowiekiem, jego naturą oraz wieloma aspektami życia - prawami, mniejszościami seksualnymi, rolami płciowymi, ekologią, priorytetami, polityką, ojczyzną, religią - które zostały uszczegółowione poprzez wskazanie konkretnych przekonań ${ }^{15}$. W wypowiedziach respondentów możliwe jest również odnalezienie ich bardziej ogólnikowych określeń, np. zgodnych z przekonaniami charakterystycznymi dla ludzi zamieszkujących w mieście, dla osób wykształconych czy klasy robotniczej.

W poczynionych refleksjach nad celami wychowania ukierunkowanymi na przygotowanie do dorosłości odnaleźć można również odniesienia do wiedzy na temat kulturalnego zachowania się, rodzimych obyczajów, tradycji i historii. W rodzicielskich dążeniach wychowawczych nie zabrakło również tych skupionych na ogólnie rozumianej w perspektywie globalizacji kulturze światowej oraz dziedzictwie kulturowym konkretnych krajów mogących się potencjalnie stać destynacjami emigracji zarobkowej w okresie dorosłości.

$\mathrm{Z}$ analizowanym komponentem kompetencji, w dyskursie codzienności zwłaszcza, łączona bywa mądrość. Tematyka ta pojawia się w wypowiedziach kilkorga respondentów, sytuując się na styku wiedzy i umiejętności. Mądrość utożsamiano bowiem nie tylko z wiedzą nabywaną dzięki edukacji szkolnej, ale również z umiejętnościami adaptacji do różnych sytuacji, wyboru odpowiedniego postępowania, zarządzania pieniędzmi, zachowania dobrego samopoczucia czy właściwych relacji z innymi osobami, unikania problemów i radzenia sobie z nimi, odróżniania dobra od zła, kreowania dobrych pomysłów, kierowania się własnymi poglądami i nieulegania presji innych.

Wskazane powyżej umiejętności nie były jedynymi werbalizowanymi przez rodziców, bowiem ten element kompetencji postrzegano również jako warunek osiągnięcia założenia wyrażanego w języku potocznym jako „radzenie sobie w życiu”. Jego doprecyzowanie pozwala na wyróżnienie trzech obszarów umiejętności niezbędnych

${ }^{15}$ Zarówno objętość niniejszego artykułu, jak i wielość konkretnych przekonań uniemożliwia ich drobiazgowe omówienie. 
w dorosłym życiu, odnoszących się kolejno do codzienności, aktywności zawodowej oraz umożliwiających awans społeczny.

W zakresie życia codziennego, na najbardziej ogólnym poziomie, rodzice chcieli, by dzieci potrafiły właściwie zaplanować i zorganizować swoje aktywności zarówno w dłuższej, jak i krótszej perspektywie czasowej. Szerokie pole refleksji stanowiły umiejętności odnoszące się do czynności podejmowanych przez człowieka w gospodarstwie domowym. W tej sferze odnaleźć można zarówno egzemplifikacje poglądów, na gruncie których obowiązki domowe postrzegane są zgodnie ze stereotypami płciowymi, jak i charakterystycznym dla współczesności partnerskim ich podziałem. Dostrzeżono również znaczenie życia rodzinnego, dla którego codzienność jest naturalną przestrzenią. I tak rodzice pragnęli, by ich potomstwo potrafiło znaleźć partnera życiowego, stworzyć zgodną rodzinę, a także wychowywać dzieci. Inny rodzaj umiejętności związany jest z kategorią wyboru. I tak dzieci miały umieć wybierać odpowiednie wartości i poglądy, a także potrafić ich racjonalnie bronić i z nich nie rezygnować.

Katalog umiejętności zapewniających prawidłowe funkcjonowanie w roli pracownika również jest szeroki. Pierwsze $\mathrm{z}$ nich związane są z podołaniem wyzwaniu znalezienia pracy, a także z poszukiwaniem alternatywnych dróg zatrudnienia. Dzieci powinny również potrafić podjąć właściwą decyzję dotyczącą rodzaju wykonywanego zawodu. W opiniach rodziców powinien on przykładowo być wysoko opłacany, społecznie użyteczny, łatwy do znalezienia, „zawsze potrzebny”, zgodny z zainteresowaniami i mocnymi stronami dziecka, ambitny, przynoszący satysfakcję czy pozwalający na kontynuowanie tradycji rodzinnych. Respondenci ponadto deklarowali chęć wyposażenia dzieci w umiejętności gwarantujące utrzymanie zatrudnienia.

Umiejętności wskazywane przez rodziców jako niezbędne dla osiągnięcia bardziej ogólnego celu wychowania utożsamianego z awansem społecznym nie pozostają bez związku z tymi odnoszącymi się do dwóch opisanych wcześniej sfer. Egzemplifikacją tej tezy jest stwierdzenie, że potomstwo powinno potrafić znaleźć takiego partnera życiowego, by podwyższyć swój status społeczny („wżenić się w dobrą rodzinę”). Ponadto uważano, że konieczne jest posiadanie umiejętności i wiedzy na temat zachowywania się i podejmowania takich działań, by otoczenie odnosiło wrażenie, że człowiek jest członkiem wyższej klasy lub „pasuje” do niej. Za warunek awansu społecznego postrzegane było również aktywne uczestnictwo w kulturze, a także posługiwanie się językiem obcym. W rodzicielskich refleksjach teleologicznych obecne są również przekonania, że należąc do klas uprzywilejowanych (zarówno poprzez urodzenie, jak i awans), dorosły powinien cechować się określonymi postawami związanymi z pewnymi społecznie pożądanymi cechami osobowości, elitarnymi zainteresowaniami, określonymi poglądami czy akceptującymi postawami wobec innych osób.

Cele wychowania ukierunkowane na przygotowanie do dorosłości w zakresie postaw stosunkowo często, jak wcześniej sygnalizowano, związane są z intencją, by dziecko było „jakiegoś rodzaju” człowiekiem. Najpowszechniej ma to być ktoś „do- 
bry” lub „porządny”. Rozmowa z rodzicami skierowana na doprecyzowanie tych ogólnych epitetów pozwala skonstatować, że są to pojęcia wieloaspektowe i różnie rozumiane. I tak utożsamiano je z postawami opartymi na mądrości, gotowości do pomocy, współczuciu, uczciwości, religijności oraz właściwym traktowaniu innych ludzi. Ponadto dobry człowiek bywał rozumiany jako taki, który „umie dobrze robić, wie co jest dobre a co złe, ma rodzinę i o nią dba” oraz nie jest przyczyną doświadczania przez inne osoby smutku, nie wstydzi się własnej rodziny i jest uczciwy. Człowiek porządny nie posiada natomiast nałogów, potrafi odróżniać dobro od zła, „nie szwenda się z kolegami, tylko domu się trzyma”, nie kradnie, nie zabija, chodzi do kościoła, cechuje się patriotyzmem odzwierciedlającym się w braku emigracji z ojczyzny oraz uwzględnia inne niż materialne dążenia.

Fundamentalnym obszarem artykułowanych przez rodziców celów ukierunkowanych na przygotowanie do dorosłości są również postawy wobec innych. Ich treść, podobnie jak w przypadku innych komponentów charakteryzowanych kompetencji, jest niejednolita. I tak w wypowiedziach rodziców można odnaleźć dwojakie dążenia, zarówno dotyczące postaw związanych z szacunkiem wobec innych ludzi, ich niekrzywdzeniem i przejawianiem wobec nich zachowań odzwierciedlonych w słowach „nie rób drugiemu, co tobie niemiłe”, jak i te cechujące się brakiem zaufania wobec innych osób, nieokazywaniem im dobroci czy takich ich traktowaniem, by „nikt [...] nie podskoczył”. Wychowując swoje dzieci, matki i ojcowie werbalizowali również cele mające związek z postawami wobec osób odmiennych kulturowo. Zazwyczaj rodzice chcieli, by ich potomstwo w przyszłości tolerowało przedstawicieli innych niż rodzima kultura, rzadziej budowali niechętny stosunek wobec nich, a także starali się wdrażać dzieci do ich akceptacji i współdziałania z nimi.

Rodzice, określając cele wychowania, odnosili się również do wartości, które miały zostać zinternalizowane przez dzieci. Za punkt odniesienia przyjmując ich klasyfikację sformułowaną przez R. Jedlińskiego ${ }^{16}$, należy podkreślić, że przeważały te moralne (uczciwość, szczerość, honor, miłość, odpowiedzialność, szczerość, tolerancja, sprawiedliwość, niezależność, sumienie, wolność) i społeczne (patriotyzm, ojczyzna, niepodległość, przyjaźń, rodzina, gender $\left.{ }^{17}\right)$.

Ryzykowne i obarczone subiektywnością jest wartościowanie wskazanych przez rodziców kompetencji w perspektywie ich użyteczności czy to dla dorosłości, czy w perspektywie wyzwań XXI wieku. Możliwe jest jednak ponowne odniesienie się do

${ }^{16}$ R. Jedliński, Świat wartości uczniów kończacych szkołę podstawową, [w:] Z. Uryga (red.), Podmiotowy wymiar szkolnej polonistyki. Materialy z konferencji „Antropocentryczno-kulturowy nurt w kształceniu polonistycznym", Wydawnictwo Naukowe WSP, Kraków 1998, s. 176.

${ }^{17} \mathrm{Z}$ uwagi na różnorodność znaczeń przypisanych pojęciu gender w dyskursie społecznym i medialnym zasadne jest wskazanie, w jaki sposób słowo to jest rozumiane przez rodziców wskazujących je jako wartość. I tak w ich wypowiedziach pojawiały się odniesienia do równoważności i równouprawnienia płci w różnych sferach życia, a także możliwości swobodnego funkcjonowania w społeczeństwie niezależnie od posiadanej tożsamości płciowej. 
idei pedagogiki kompetencji ${ }^{18}$ i skonstatowanie, że mają one zarówno zgodny z nią wymiar ukierunkowany na podmiotowość jednostki, jak i sprzeczny - stricte adaptacyjny.

\section{Zakończenie}

Podjęte w niniejszym artykule rozważania zmierzały do rozjaśnienia znaczeń wpisanych w cel wychowania, jakim jest przygotowanie do dorosłości, za którego realizację rodzinę czyni się odpowiedzialną tak na gruncie dyskursu społecznego, jak i naukowego. Na najbardziej ogólnym poziomie skonstatować należy, że owe sensy cechują się heterogenicznością będącą zarówno konsekwencją samej złożoności procesu wychowania (również rodzinnego), jak również, co pokazały badania własne, odziaływania szeregu czynników o charakterze aksjologicznym, społecznym, edukacyjnym, światopoglądowym, kulturowym czy indywidualnym związanym z doświadczeniami rodziców dotyczących przykładowo wychowania w rodzinie pochodzenia czy postrzegania swojej obecnej sytuacji życiowej.

Formułując wnioski o wyższym stopniu uszczegółowienia, rozpocząć należy od namysłu nad zupełnością obrazu dorosłości oraz treścią przygotowania do dorosłości jako celu wychowania. Oba te komponenty świadomości teleologicznej rodziców cechują się fragmentarycznością i wydają się mieć wymiar bardzo indywidualny. Zgodnie z tym, co sygnalizowano wcześniej, dorosłość postrzegana jest przez pryzmat wyzwań i trudności z nią związanych, przy jednoczesnym nieuwzględnianiu potencjałów, które ją konstytuują. Ponadto w rodzicielskich refleksjach brakuje mniej oczywistych ról, które podejmowane są przez człowieka dorosłego. Treść celów wychowania skoncentrowana jest na kompetencjach mających wymiar uniwersalny, zapewniających poprawne, ale jednocześnie raczej konformistyczne funkcjonowanie człowieka. Rodzice, formułując cele wychowania, wydają się nie dostrzegać lub nie uwzględniać specyficznych cech współczesności wymagających innej niż dawniej wiedzy, nowych umiejętności, postaw czy odmiennego nastawienia oraz podejmowania działań o charakterze emancypacyjnym czy twórczym.

Druga bardziej szczegółowa konstatacja wyraża się w pytaniu o rolę dzieci jako uczestników wychowania ukierunkowanego na przygotowanie do dorosłości. W tym sensie nie sposób nie zastanowić się na tym, czy mają być one aktywnymi i twórczymi podmiotami tego procesu, czy może przyjmować wpływy i adekwatnie reagować na działania podejmowane przez rodziców i w ten sposób przyczyniać się do realizacji formułowanych przez nich celów. Odpowiedź na to pytanie oczywiście nie jest jednoznaczna, jednakże precyzyjne wizje przyszłości dziecka, jego zadań i kompetencji posiadane przez wychowawcę ograniczają zakres podmiotowości wychowanków oraz możliwości realizacji ich potencjału i osobistych celów samowychowania.

\footnotetext{
${ }^{18}$ M. Nowak, dz. cyt., s. 422-423.
} 
Wreszcie należy skonfrontować sensy wpisane w przygotowanie do dorosłości jako cel wychowania rodzinnego z tymi obecnymi w wychowaniu szkolnym, a także kulturze popularnej będącej współcześnie ważnym czynnikiem socjalizacyjnym. Kwestia ta wymaga pogłębionych badań, postanowiono ją zatem jedynie zasygnalizować jako pole do dalszych refleksji.

\section{Bibliografia}

Bereźnicka M., Wychowanie dziecka we współczesnej rodzinie, Wydawnictwo Naukowe Uniwersytetu Pedagogicznego, Kraków 2014.

Biedroń M., Realizacja funkcji rodziny w kontekście globalnych przemian socjokulturowych, [w:] A. Ładyżyński (red.), Rodzina we współczesności, Oficyna Wydawnicza Atut, Wrocław 2009.

Bourdieu P., Dystynkcja. Społeczna krytyka sądzenia, Wydawnictwo Naukowe Scholar, Warszawa 2005.

Czeredrecka B., Rodzina jako środowisko życia i wychowania, [w:] U. Gruca-Miąsik (red.), Dziecko i rodzina. Społeczne powinności opieki i wychowania, WUR, Rzeszów 2007.

Farnicka M., Przemiany realizacji zadań rozwojowych. Ewolucja czy rewolucja?, Uniwersytet Zielonogórski, Zielona Góra 2011.

Frindt A., Czy warto być dorosłym? Społeczno-kulturowe uwarunkowania pojęcia dorosłości wświadomości młodzieży wielkomiejskiej, Wydawnictwo Akademickie Żak, Warszawa 2005.

Giddens A., Socjologia, Wydawnictwo Naukowe PWN, Warszawa 2012.

Jedliński R., Świat wartości uczniów kończących szkołe podstawowa, [w:] Z. Uryga (red.), Podmiotowy wymiar szkolnej polonistyki. Materiały z konferencji „Antropocentrycznokulturowy nurt $w$ kształceniu polonistycznym”, Wydawnictwo Naukowe WSP, Kraków 1998.

Kamiński A., Funkcje pedagogiki społecznej: praca socjalna i kulturalna, Państwowe Wydawnictwo Naukowe, Warszawa 1980.

Kiereś B., Rodzina jako miejsce kształtowania charakteru człowieka, „Cywilizacja”, nr 6/2008.

Kozubowska U., Rodzina jako najważniejsza przestrzeń kształtowania się systemu wartości i tożsamości dziecka, [w:] W. Muszyński (red.), Wartości w rodzinie: ciągłość i zmiana, Wydawnictwo Adam Marszałek, Toruń 2010.

Kułaczkowski J., Cechy rodziny jako środowiska wychowawczego, [w:] J. Kułaczkowski (red.), Leksykon pedagogiki rodziny, Bonus Liber. Wydawnictwo i Drukarnia Diecezji Rzeszowskiej, Warszawa 2011.

Mikiewicz P., Kapitał społeczny i edukacja, Wydawnictwo Naukowe PWN, Warszawa 2014. 
Nowak M., Od pedagogiki celów do pedagogiki zadań i kompetencji, [w:] E. Ogrodzka-Mazur, A. Szczurek-Boruta (red.), Poza paradygmaty. Pedagogika wielostronna. Ksiega pamiatkowa dedykowana profesorowi Tadeuszowi Lewowickiemu, t. 1, Wydawnictwo Adam Marszałek, Toruń 2012.

Oleś P., Psychologia człowieka dorosłego: Ciagłość - zmiana - integracja, Wydawnictwo Naukowe PWN, Warszawa 2011.

Opozda D., Struktura i treść jednostkowej wiedzy o wychowaniu. Studium pedagogiczne wiedzy rodziców i jej korelatów, Towarzystwo Naukowe KUL-Katolicki Uniwersytet Lubelski Jana Pawła II, Lublin 2012.

Suchodolski B., Zagadnienia podstawowe, [w:] B. Suchodolski (red.), Pedagogika. Podręcznik dla kandydatów na nauczycieli, t. 1, Państwowe Wydawnictwo Naukowe, Warszawa 1985.

Świdrak E., Świadomość wychowawcza we wspótczesnej rodzinie, Wydawnictwo KUL, Lublin 2013.

Zawadzka E., Wspótczesne uzasadnienia celów wychowania rodzinnego wświetle badań nad celami wychowania w rodzinach o zróżnicowanym poziomie wykształcenia rodziców, [w:] D. Opozda, M. Leśniak (red.), Rodzicielstwo w wybranych zagadnieniach pedagogicznych, Episteme, Lublin 2017.

\section{Preparation for adulthood as an objective of upbringing}

Abstract: The paper, based on my own qualitative research, addresses the issue of preparation for adulthood as an objective of upbringing. The text is comprised of the introduction, three main sections, and the conclusion. The introduction presents some general reflections on family upbringing, and also outlines the purpose of the considerations undetaken in the paper. The three main sections in turn deal with: preparation for adulthood against the backdrop of parents' teleological awareness, the image of adulthood as part of the objectives of upbringing meant to prepare for adulthood, human competencies of an adult, as reflected in the objectives of upbringing meant to prepare for adulthood. The final section presents conclusions concerning the completeness of the parents' images of adulthood, and the content of analysed objectives, as well as the role of children in the process of preparation (getting ready) for adulthood.

Keywords: family upbringing, objectives of upbringing, preparation for adulthood, teleology of upbringing, upbringing

\footnotetext{
About the author: Edyta Zawadzka - PhD in Social Sciences in the field of pedagogy, Assistant Professor in the Maria Grzegorzewska Pedagogical University. Academic interests: teleology of education and educationalisation of everyday life.
} 


\title{
Seksting i wybrane kwestie związane z seksualnością w opiniach młodych kobiet i mężczyzn
}

DOI: 10.25312/2083-2923.15/2019_02mb

\begin{abstract}
Streszczenie: Artykuł porusza problem seksualności, do której podejście, zwłaszcza młodych ludzi, zmieniło się w dużej mierze dzięki rozwojowi nowoczesnych technologii. Upowszechnienie Internetu i telefonii komórkowej przyczyniło się do coraz swobodniejszego udostępniania prywatnych, a nawet intymnych, zdjęć czy filmów nieograniczonej liczbie odbiorców. W artykule przybliżono analizę wyników badań własnych, mających na celu zbadanie opinii młodych kobiet i mężczyzn dotyczących seksualności, a przede wszystkim sekstingu. Przedstawiono również najważniejsze wnioski.
\end{abstract}

Słowa kluczowe: seksualność, seksting, opinie, postawy, zagrożenia internetowe

\section{Seksualność na zdjęciach kiedyś i dziś}

Prywatność, jak sama nazwa wskazuje, należała dawniej do strefy, której się strzegło i nie udostępniało nikomu, poza wąskim gronem najbliższych. Obecnie, w wielu przypadkach wartość ta staje się walutą, co dość wyraźnie ilustruje przykład tego, co dzieje się z fotografiami. Prywatne zdjęcia, w nie tak odległej przeszłości, w której Internet nie był jeszcze powszechny, pozostawały sprawą osobistą. Wyjątek stanowiły materiały medialne, które przede wszystkim ograniczały się do osób popularnych, postaci znanych z show-businessu, artystów, prezenterów, sportowców, polityków etc., których wizerunek był wykorzystywany i kreowany w telewizji i prasie. Natomiast bardzo była chroniona seksualność osób prywatnych, a erotyka pojawiająca się w filmach i czasopismach przeznaczona była wyraźnie dla dorosłych odbiorców.

"Małgorzata Bereźnicka - doktor habilitowany, profesor Uniwersytetu Pedagogicznego im. KEN w Krakowie. Zainteresowania naukowe: pedagogika społeczna, pedagogika rodziny, wartości, edukacja dla bezpieczeństwa, komunikacja, bezpieczeństwo w sieci, patologie społeczne. 
Oczywiście, wzmożone utrudnienia dotyczyły tym bardziej pornografii, chociaż stopniowo oswajano społeczeństwo z tym tematem, np. poprzez - sporadyczne dawniej ukazywanie w mediach coraz bardziej skandalizujących wizerunków głównie aktorek lub piosenkarek w negliżu czy wyzywających pozach.

Internet, który $\mathrm{w}$ wielu aspektach zmienił oblicze świata, wpłynął na pojawienie się nowych trendów także w powyższym obszarze. Po pierwsze, jego upowszechnienie sprawiło, że w zasadzie każdy może zamieszczać w przestrzeni dostępnej dla nieograniczonej liczby osób materiały (m.in.) o charakterze seksualnym. Po drugie, presja dotycząca atrakcyjności fizycznej (kult młodości, idealnej sylwetki, a także bycia godnym pożądania) i coraz bardziej liberalne podejście do nagości i erotyki sprawiły, że wiele osób (w tym także płci męskiej) pragnie eksponować swoją seksualność i ukazywać ją innym. W dużym stopniu dotyczy to młodych osób, których idole i idolki z pewnością przyczyniają się do rozszerzania się tego zjawiska. Prezentowane przez nich obrazy niejednokrotnie przekraczają granice dobrego smaku, a niestety kontrowersyjność dobrze się sprzedaje, więc im bardziej czyjeś postępowanie jest bulwersujące, tym o nim głośniej.

Zdjęcia czy filmy $\mathrm{z}$ takimi osobami (m.in. teledyski) przepełnione są nie tylko erotyką, ale nawet treściami pornograficznymi, które uprzedmiotawiają człowieka i w szczególności wysyłają sygnały nieodpowiednie do naśladowania dla młodego odbiorcy. Jako przykład można podać piosenkarkę Miley Cyrus, na której koncertach bawią się rzesze dzieci i młodzieży. Ta była dziecięca „gwiazda Disneya”, publicznie symulująca kopulację, dotykająca swoich miejsc intymnych i prezentująca całą listę wulgarnych i (nawet dzisiaj) szokujących zachowań, uznaje się równocześnie za jedną z bogatszych i wpływowych młodych kobiet ${ }^{1}$. Podobnych przykładów można by przytoczyć więcej (Rihanna, Lady Gaga, Nicky Minaj, Kim Kardashian, w Polsce Doda). Warto podkreślić, że współcześnie także mężczyźni epatują swoją seksualnością (Justin Bieber, Adam Lambert), co wcześniej należało do rzadkości w mediach masowych, stanowiąc jednak głównie domenę kobiet. Oprócz gwiazd muzyki pop przedmiotowe traktowanie własnej lub cudzej seksualności pojawia się również w przekazach czy zdjęciach aktorów, blogerów, influencerów (ang. influence - wpływać) etc.

Naukowcy zwracają uwagę na ciałocentryczność kultury masowej i związane z nią wizerunki kobiecości lub męskości oraz na rolę wyglądu w dzisiejszej kulturze konsumpcyjnej². Wydaje się, że trudno dyskutować z wpływem mediów na to, jak po-

${ }^{1}$ Z. Johnson, Miley Cyrus Makes Time's 100 Most Influential People; Dolly Parton Explains Her "Drastic" Makeover, https://www.eonline.com/news/535222/miley-cyrus-makes-time-s-100-most -influential-people-dolly-parton-explains-her-drastic-makeover (dostęp: 15.10.2018).

${ }^{2}$ M. Featherstone, Ciało w kulturze konsumpcyjnej, [w:] M. Szpakowska (red.), Antropologia ciała. Zagadnienia i wybór tekstów, Wydawnictwo Uniwersytetu Warszawskiego, Warszawa 2008; Z. Melosik, Tożsamość, ciało i władza w kulturze instant, Oficyna Wydawnicza Impuls, Kraków 2010 . 
strzegają swoje ciała ich odbiorcy ${ }^{3}$. Dlatego traktowanie ciała jako towaru w mass mediach - oprócz Internetu wspomagają ten trend liczne programy telewizyjne czy zdjęcia i artykuły w czasopismach - powoduje swoiste oswajanie się odbiorców z takim podejściem i może skutkować tym, że zacznie być postrzegane jako norma przez wielu młodych ludzi ${ }^{4}$ Granice przesuwają się coraz dalej, o czym świadczy fakt, że coraz częściej, zwłaszcza dziewczęta, już nie tylko udostępniają np. na portalach społecznościowych swoje fotografie o erotycznym wydźwięku, ukazujące je nago lub w negliżu, ale część z nich nie dostrzega niczego niewłaściwego w sprzedawaniu takich materiałów. Bywa, że nastolatki, także małoletnie, oferują pornograficzne zdjęcia lub filmy anonimowym użytkownikom sieci np. za doładowanie telefonu ${ }^{5}$. Dodajmy do tego, że media, choć podsycają kult (młodego, seksownego wyglądu) i epatują cielesnością, nie sprzyjają jednocześnie budowaniu świadomości w tym temacie. J. Femiak i P. Rymarczyk piszą wręcz o uprzedmiotowieniu i instrumentalizacji relacji między ciałem i ,ja”, argumentując następująco:

Choć współczesna kultura masowa nieraz uznawana jest za rzeczniczkę cielesno-zmysłowego wyzwolenia - i mimo że chętnie się jako taka rzeczniczka prezentuje - to wzywając swych odbiorców do aktywności cielesnej, w istocie pozostawia im zazwyczaj niewiele swobody. Wynika to niewątpliwie z jej komercyjnego charakteru, który sprawia, że twórcy medialnych przekazów są zainteresowani wywoływaniem jedynie tych form aktywności cielesnej, które są związane z nabywaniem określonych towarów. Efektem jest paradoksalna sytuacja, w której ciałocentryczności kultury wydaje się towarzyszyć ogólnie niski poziom tego, co nazwać by można cielesną samoświadomością członków społeczeństwa. Jednostki nie pyta się bowiem o to, jakich doświadcza pragnień cielesnych i co za pośrednictwem swego ciała przeżywa, lecz raczej podpowiada jej się, czego ma chcieć i co ma przeżywać (a przynajmniej udawać, że to przeżywa) ${ }^{6}$.

Wśród nowoczesnych środków przekazu specyficznie na odbiorców oddziałują media elektroniczne, tworzące wirtualną rzeczywistość, która jest w stanie, jak dowodzi J. Szmyd,

[...] w swojej obrazowości, dynamice, sile oddziaływania na człowieka, oraz w różnorakich mechanizmach psychologicznych i społecznych, podporządkować go sobie coraz bardziej skutecznie. Nie jest to już tylko taką czy inną alternatywą realnej rzeczywistości, ale odrębną, jak gdyby drugą rzeczywisto-

${ }^{3}$ M. McCabe, K. Butler, C. Watt, Media Influences on Attitudes and Perceptions Toward the Body Among Adult Men and Women, „Journal of Applied Biobehavioral Research”, nr 12(2)/2007.

${ }^{4}$ K. Karsay, J. Knoll, J. Matthes, Sexualizing Media Use and Self-Objectification: A Meta-Analysis, „Psychology of Women Quarterly”, nr 42(1)/2017.

5 A. Grabau, Seksting - nastoletnia pornografia, „Tygodnik Przegląd”, 11.03.2012, https://www. tygodnikprzeglad.pl/seksting-nastoletnia-pornografia/ (dostęp: 25.07.2018); S. Bębas, Sexting nowe zagrożenie wśród dzieci i młodzieży, „Labor et Educatio”, nr 3/2015, s. 442.

${ }^{6}$ J. Femiak, P. Rymarczyk, Ciało jako temat narracji kultury masowej i narracji wewnętrznej, „Rozprawy Naukowe AWF we Wrocławiu”, nr 49/2015, s. 30. 
ścią. Jest „światem” tworzonym przez media i podawanym odbiorcy nie tyle do poznawania zwyczajnego, tzn. zmysłowego i wewnętrznego (introspekcyjnego) doświadczania i przeżywania, co do zabawy i oglądania oraz swoistego „odlotu" od realnego świata, a nierzadko też do swego rodzaju „opiumowania” indywidualnego lub zbiorowego życia. Jest więc nie tylko rosnącym na znaczeniu substytutem rzeczywistości, ale pewną, o wiele bardziej szkodliwą, co poważną alternatywą dla poznawczo-dyskursywnego i empiryczno-doświadczalnego odnoszenia się do ontycznej (bytowej) rzeczywistości; alternatywą, która staje się ewidentnym zagrożeniem dla właściwego „odczytywania” i rozumienia tejże rzeczywistości przez przeciętnego człowieka i wpływa na coraz większe jego wyobcowanie się od realnego świata ${ }^{7}$.

Owe odczytywanie i rozumienie odnosi się do wielu różnych sfer życia, obejmując również kwestie związane z wyglądem, ciałem i cielesnością, intymnością, seksualnością oraz podejściem do tych zagadnień.

W niniejszym artykule pragnę ograniczyć się do problemu, jakim jest samo przesyłanie drogą elektroniczną lub publikowanie w sieci materiałów - wiadomości, zdjęć, filmów - o charakterze erotycznym bądź pornograficznym. Celowo odniosłam się tutaj do obu rodzajów treści, ponieważ granica między erotyką i pornografią bywa bardzo cienka. Seksting (ang. sex - seks, płeć; texting - SMS-owanie), bo o nim mowa, chociaż sam termin nie posiada spójnej definicji prawnej ${ }^{8}$, jako zjawisko stał się na tyle popularny, że powstają nawet poradniki, w jaki sposób robić to profesjonalnie ${ }^{9}$. Jednocześnie prowadzi się coraz więcej badań nad tym zjawiskiem, zarówno międzynarodowych (np. w ramach EU Kids Online ${ }^{10}$ ), jak i ogólnopolskich ${ }^{11}$. Powstaje również coraz więcej bardziej lub mniej naukowych publikacji, w których zwraca się uwagę na zagrożenia, jakie niesie ze sobą seksting (zarówno konsekwencji prawnych, jak i moralnych czy społecznych, powodujących ostracyzm, a w skrajnych przypadkach mogących doprowadzić nawet do samobójstwa), i szuka się odpowiedzi na pytanie, dlaczego, mimo tych zagrożeń, nastolatki podejmują takie ryzyko i w jaki sposób można temu przeciwdziałać ${ }^{12}$.

7 J. Szmyd, Medialny obraz rzeczywistości jako główna orientacja poznawcza i praktyczna w świecie, [w:] K. Pokorna-Ignatowicz (red.), Medialny obraz rodziny i płci, Oficyna Wydawnicza AFM, Kraków 2012, s. 24.

${ }^{8}$ K. Martinez-Prather, D.M. Vandiver, Sexting among Teenagers in the United States: A Retrospective Analysis of Identifying Motivating Factors, Potential Targets, and the Role of a Capable Guardian, „International Journal of Cyber Criminology”, nr 8(1)/2014, s. 23.

9 T. Horn, Sexting: The Grownup's Little Book of Sex Tips for Getting Dirty Digitally, Fair Winds Press, 2016.

${ }^{10}$ L. Kirwil, A. Zdrodowska, Zagrożenia online: klasyfikacja i rozpowszechnienie wśród dzieci w wieku 9-16 lat. Dane z paneuropejskich badań EU Kids Online, referat na konferencji „Między Dniem Ochrony Danych Osobowych a Dniem Bezpiecznego Internetu”, OEIiZK, Warszawa 4.02.2015.

${ }^{11}$ S. Wójcik, K. Makaruk, Seksting wśród polskiej młodzieży, FDN, 2014, http://fdds.pl/wp-content/ uploads/2016/05/Wojcik Makaruk Seksting wsrod polskiej mlodziezy.pdf (dostęp: 27.09.2018).

${ }^{12}$ P.D. Netzley, Teens and Sexting. Teen Choices, Reference Point Press, San Diego CA 2015. 


\section{Seksting w badaniach własnych}

W 2017 roku przeprowadziłam pośród studentów Uniwersytetu Pedagogicznego (I rok na kierunku Bezpieczeństwo narodowe) badania dotyczące aktywności młodych ludzi w Internecie oraz cyberzagrożeń, ze szczególnym uwzględnieniem sekstingu. Wybrałam studentów pierwszego roku, aby byli to ludzie jak najmłodsi, a jednak pełnoletni, biorąc pod uwagę delikatną materię badań. Dobór kierunku, na którym studiowali, podyktowany był związkiem podejmowanej tematyki z bezpieczeństwem, leżącym w sferze zainteresowań studentów, którzy zatem - przynajmniej teoretycznie - powinni być bardziej świadomi zagrożeń związanych z korzystaniem z nowoczesnych technologii. W planowanych szerszych badaniach próba badawcza będzie liczniejsza i obejmie młodzież z różnych środowisk.

Przedstawione poniżej wyniki stanowią wycinek całości badań, których celem było dowiedzenie się, jaki respondenci mają stosunek do sekstingu. Aby rozwiązać główny problem badawczy, zadano im szereg pytań weryfikujących ich wiedzę $e^{13}$, doświadczenia oraz opinie o tym ostatnim zjawisku - w niniejszym artykule skoncentrowano się na tej ostatniej kwestii, a także na zagadnieniach pokrewnych, związanych z wyglądem, seksualnością czy oceną pornografii, które stanowiły swoiste wprowadzenie do faktycznych opinii na temat sekstingu. Studenci wypełnili ponad 100 ankiet, spośród których zakwalifikowano do analizy 100 kwestionariuszy: 62 uzyskane od kobiet oraz 38 od mężczyzn. Badani pochodzili zarówno z miast (51\%), jak i wsi (49\%). Większość z nich (4/5) wychowywała się w pełnej rodzinie, u 1/6 rodzice się rozstali, trzy osoby miały tylko jednego rodzica.

Ponieważ interesujące nas zjawisko ma wiele wspólnego z epatowaniem seksownym, atrakcyjnym wyglądem, w ramach wprowadzenia zapytano respondentów, czy ich zdaniem atrakcyjny wygląd ułatwia osiągnięcie sukcesu, a jeśli tak, to jakiego. Blisko 1/10 ankietowanych stwierdziła, że tak nie jest, pozostali (częściej mężczyźni) w większości wskazywali sukces towarzyski, ponad połowa - zawodowy (nieco częściej kobiety). Bardzo nieliczna grupa uznała, że atrakcyjny wygląd pomaga również w relacjach rodzinnych. Dodatkowo jedna osoba napisała, że dotyczy to wszystkich sfer życia.

Kolejne zagadnienie wiązało się z poprzednim, ale tym razem wymagało określenia samooceny. Pytani o postrzeganie własnej atrakcyjności respondenci odpowiadali w większości, że jest ona dla nich ważna (wykres 2). Po kilkanaście procent uznało, że nawet bardzo ważna (nieco więcej kobiet) oraz niezbyt ważna (częściej mężczyźni). Ani jedna osoba nie określiła jej jako nieważnej.

${ }^{13}$ M. Bereźnicka, Znajomość i źródła wiedzy studentów Bezpieczeństwa Narodowego o zagrożeniach zwiazanych $z$ sekstingiem, „Annales Universitatis Paedagogicae Cracoviensis, Studia de Securitate", nr 8/2018. 


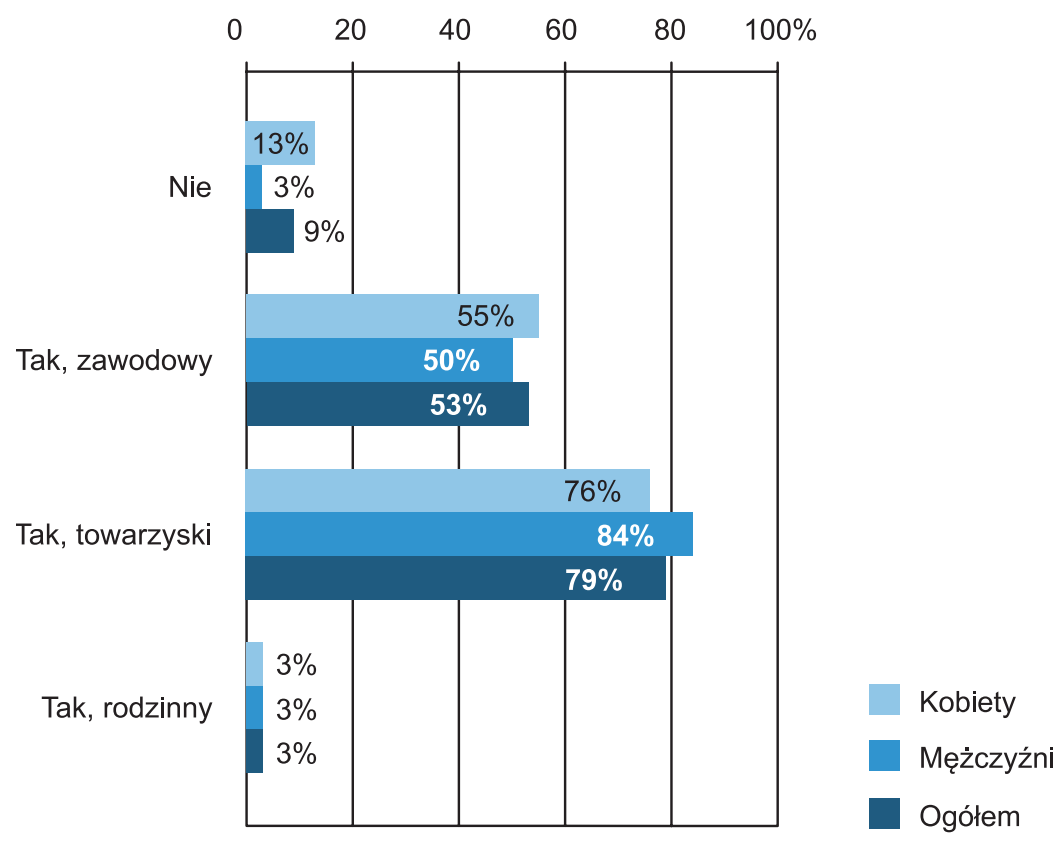

Wykres 1. Wpływ atrakcyjnego wygladu na sukces (\%)

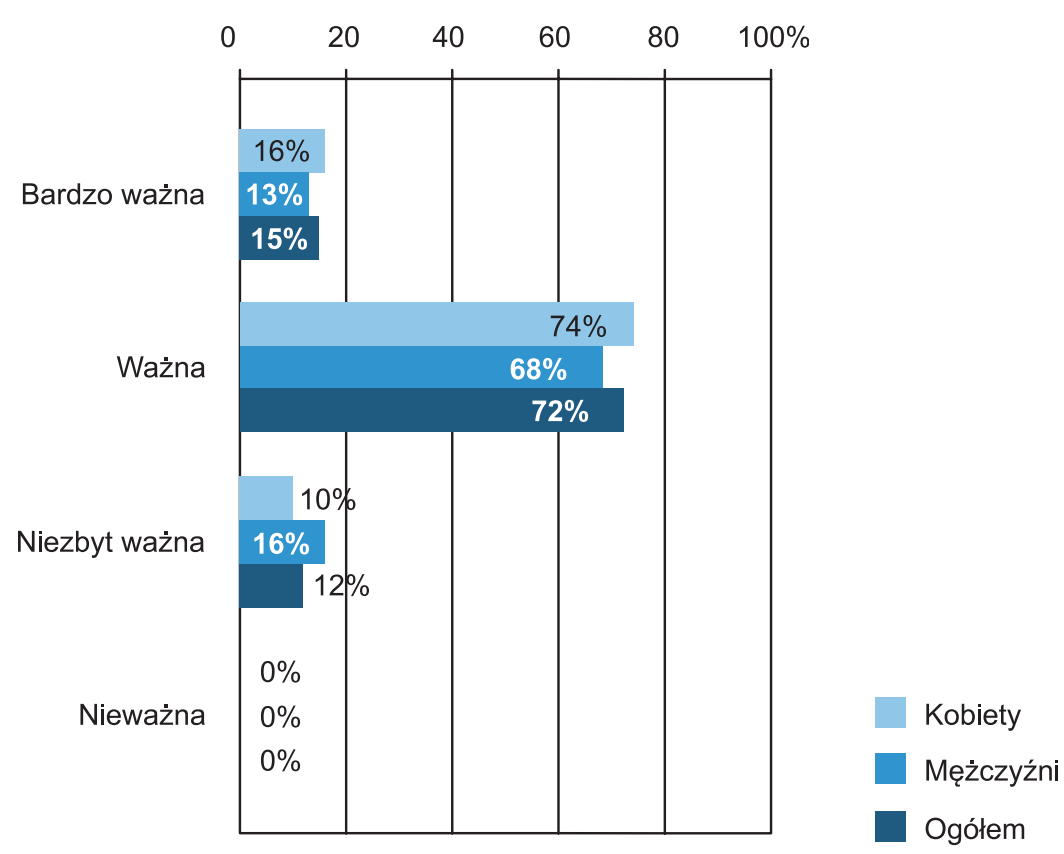

Wykres 2. Postrzeganie własnej atrakcyjności (\%)

Seksting często ma miejsce w związkach, dlatego zapytano również o postrzeganie atrakcyjności partnera/ki. Dane okazały się być bardzo zbliżone do poprzednich, 
przede wszystkim jeśli brać pod uwagę zbiorowość. Porównanie wyników uzyskanych od reprezentantów obu płci pozwala dostrzec, że dwukrotnie częściej mężczyźni wybierali odpowiedź „bardzo ważna”, natomiast kobiety - „niezbyt ważna”. Także w tym przypadku nikt nie uznał, że omawiany aspekt nie ma żadnego znaczenia. Wyniki ilustruje poniższy wykres.

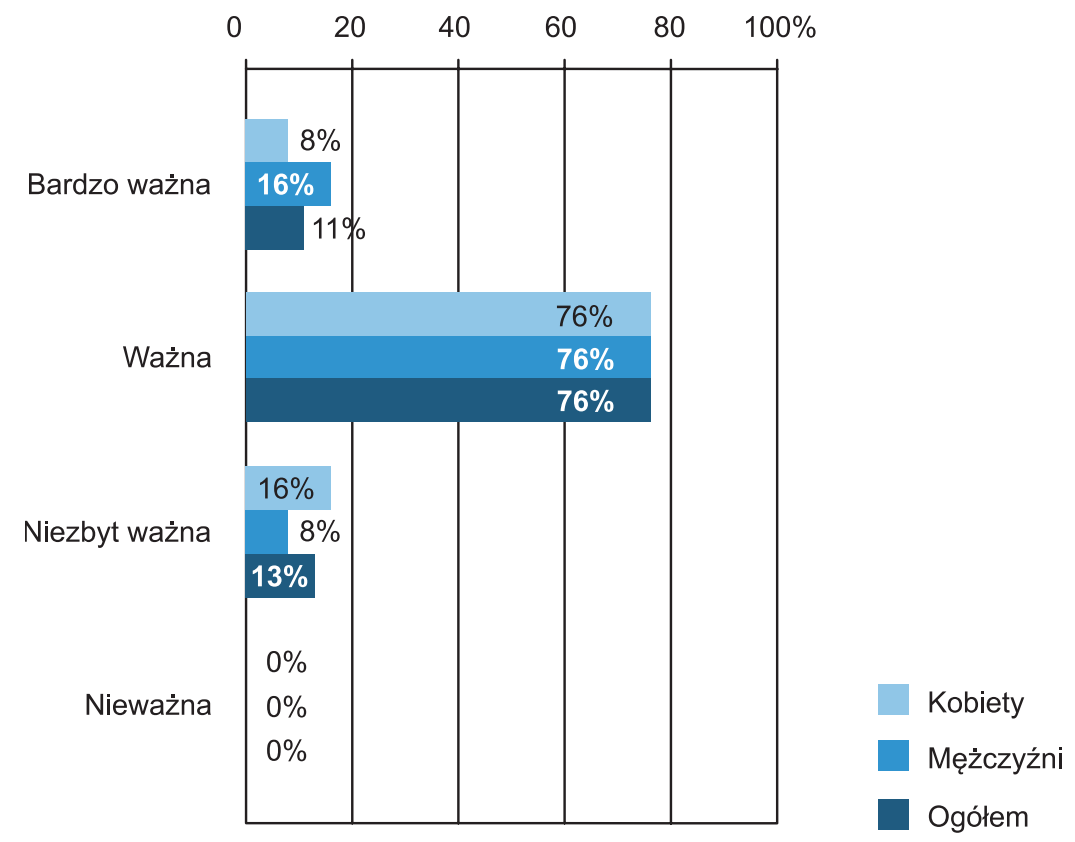

Wykres 3. Postrzeganie atrakcyjności partnera/ki (\%)

Następnie ankietowani mieli wskazać zdania, które uważają za prawdziwe, aby przybliżyć, jaki mają stosunek do seksualności. Ułożono je od prezentujących najbardziej tradycyjne podejście do najbardziej liberalnych i brzmiały one następująco:

1. Seksualność (erotyczne pozy, nagość) powinna być zarezerwowana tylko dla męża/żony.

2. Seksualność powinna być zarezerwowana tylko dla partnera/ki, niezależnie od ślubu.

3. Nie ma nic złego w pokazywaniu swojej seksualności otoczeniu, ale w pewnych granicach.

4. Seksualność stanowi towar, który należy wykorzystywać dla własnych korzyści.

O ile w kwestiach dotyczących wyglądu opinie respondentów obu płci były zbliżone, to w kwestiach związanych z seksualnością zanotowano niemałe rozbieżności. Najwięcej badanych (ponad połowa kobiet i 3/5 mężczyzn) wybrało tezę numer 2, uznając tym samym, że seksualność to sprawa intymna, którą nie powinno się dzielić z nikim poza najbliższą osobą, z którą jest się w związku. Podobne zdanie prezen- 
towała ponad 1/3 respondentów, aczkolwiek ta grupa uznała ślub za warunek konieczny. Wśród osób wyznających to najbardziej tradycyjne podejście zdecydowanie przeważały kobiety, które wskazywały tezę numer 1 ponad dwukrotnie częściej niż ich koledzy. Trzecia teza została wybrana przez 1/5 ankietowanych i tym razem przeważali niemal dwukrotnie mężczyźni. Zaskakujące w tym kontekście są wyniki odnoszące się do ostatniej tezy numer 4, głoszącej, iż seksualność to towar, gdzie ponownie przeważają głosy kobiet. Dane przedstawiono na poniższym wykresie.

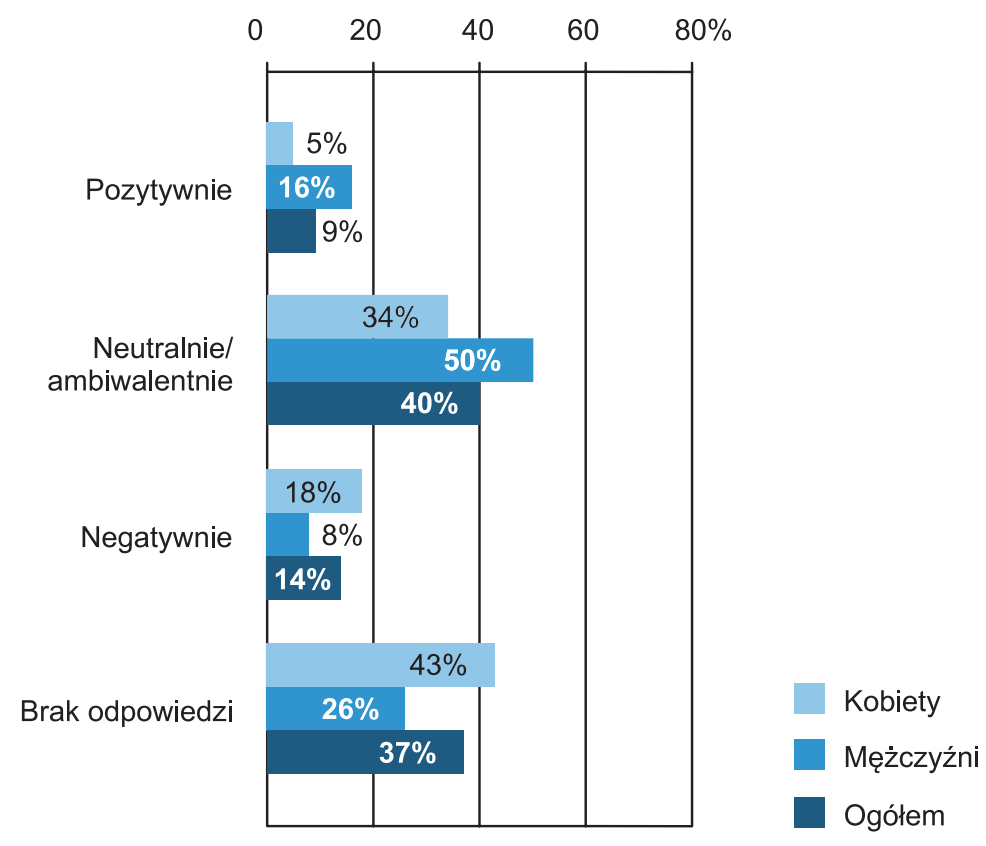

Wykres 4. Podejście do seksualności (\%)

Mimo że powyższe tezy prezentują odmienne stanowiska, część studentów zaznaczała tu więcej niż jedną odpowiedź, co może świadczyć o tym, że ich opinie w tym zakresie są płynne lub zależą od różnych czynników.

Seksualność jest wszechobecna w Internecie, w którym zamieszcza się olbrzymie ilości materiałów pornograficznych. Nierzadko zdarza się i tak, że docierają one też do osób, które sobie tego nie życzą (np. jako spam). Respondentów zapytano o sytuację, w której wybór należał do nich, a konkretnie o to, czy i jak często oglądają takie treści (wykres 5). Na to pytanie odpowiedziało jedynie $82 \%$ respondentów (puste pola pozostawiło pięć studentek oraz trzech studentów), dane procentowo obliczono, biorąc pod uwagę jedynie uzyskane odpowiedzi (wykres 5). Wyniki znacznie różnią się ze względu na płeć ankietowanych. Większość kobiet (i niespełna 1/10 mężczyzn) nigdy nie oglądała zdjęć/filmów pornograficznych, po kilkanaście procent zaznaczyło odpowiedź „rzadko” oraz „czasami”. W przypadku ich kolegów wyniki odnoszące się do tych dwóch opcji to odpowiednio prawie 1/5 i blisko połowa, a dodatkowo co piąty student w tej grupie ogląda omawiane treści często. 


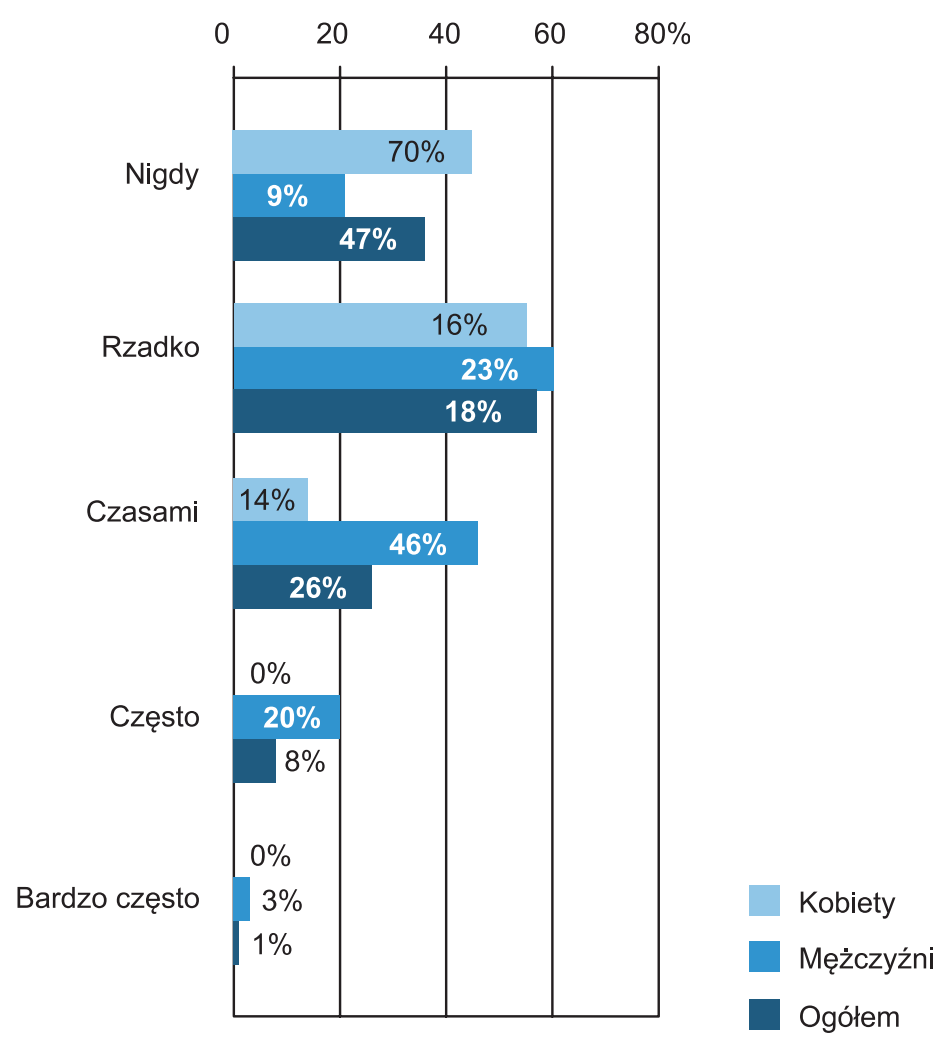

Wykres 5. Częstotliwość oglądania zdjęć/filmów porno (\%)

W zależności od płci można dostrzec także spore różnice w samym podejściu do pornograficznych zdjęć/filmów (aczkolwiek nie odpowiedziało na to pytanie ponad 2/5 studentek i 1/4 studentów. Opinie pozytywne, wybrane przez zaledwie kilka kobiet i kilkunastu mężczyzn, uzasadniano rzadko, pisano m.in. następująco: „mogą wiele nauczyć”, „dają rozrywkę”, „są super”, „są fajne”. Największa grupa ankietowanych - połowa kobiet oraz 1/3 mężczyzn - ocenia omawiane treści neutralnie lub ambiwalentnie, argumentując dla przykładu: „nic szczególnego, ale czasem trzeba”, „wszystko jest dla ludzi, ale...”, „każdy ma prawo do własnego wyboru, intymność jest osobistą sprawą”, „są obrzydliwe, ale podniecające”, czy „pobudzają wyobraźnię, ale szkodzą w relacjach partnerskich, dając odrealniony obraz seksu”. Wśród wypowiedzi potępiających pornografię (niespełna 1/5 kobiet i blisko 1/10 mężczyzn) można było znaleźć określenia takie jak: „beznadziejne”, „głupie”, „hańbiące dla człowieka”, „nieodpowiednie”, „tandetne i niesmaczne”, „patologia”, „uzależniające i szkodliwe”, „Wzbudzają moje obrzydzenie”, „mogą nieść zagrożenia”. Jedna studentka napisała bardzo niepokojącą uwagę, niewymagającą komentarza, choć skłaniającą do niewesołych refleksji: „Straszne jest to, że każdy ma do tego dostęp. W klasie mojej siostrzenicy (3. podst.) dzieci założyły klub porno, w którym oglądały filmy erotyczne”. 


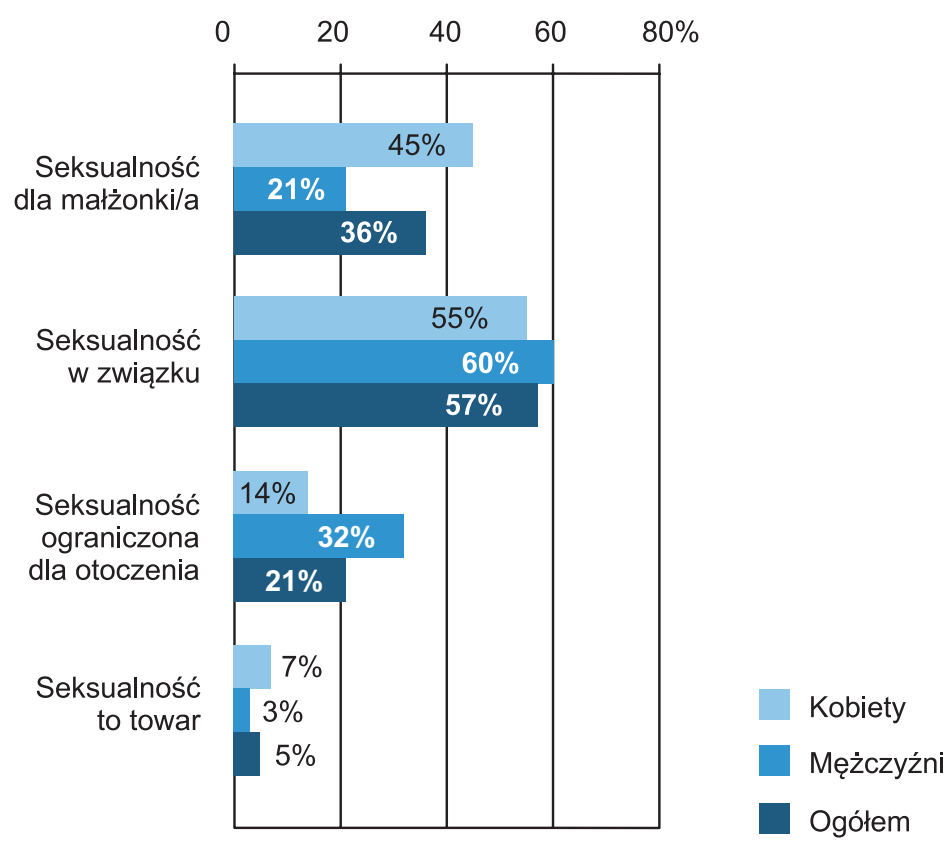

Wykres 6. Postrzeganie zdjęć/filmów porno (\%)

Wyniki z kolejnych dwóch pytań ze względu na mnogość danych liczbowych przedstawiono w tabelach, które dotyczą zbiorowości. Obie odnoszą się do oceniania sekstingu przez ankietowanych, jednak pierwsza dotyczy wiadomości tekstowych, a druga zdjęć/filmów. W każdym pytaniu respondenci mieli się ustosunkować do kwestii przesyłania tych materiałów, uwzględniając odbiorców, takich jak: chłopak lub dziewczyna, z którym/ą dana osoba się spotyka, były chłopak lub była dziewczyna (określeni w tabeli skrótowo jako „eks”), znajomy/a, osoba obca, wiele osób, nieograniczona liczba osób. Jak widać w poniższych tabelach, opinie były podzielone, zarówno biorąc pod uwagę rodzaj przesyłanych materiałów, jak i tego, do kogo się je wysyła.

Biorąc pod uwagę wiadomości tekstowe o charakterze seksualnym (tabela 1), większość respondentów ocenia je pozytywnie, jeśli dotyczą aktualnej relacji damsko-męskiej, a zaledwie kilka osób zaznaczyło tu odpowiedź negatywną. Zupełnie inaczej ma się sprawa w odniesieniu do pozostałych odbiorców, gdzie oceny pozytywne występują w pojedynczych przypadkach lub wcale, podobnie zresztą jak oceny neutralne, gdzie wyjątek stanowi jedynie sytuacja, w której wysyła się erotyczne wiadomości do byłych partnerów (wybór blisko 1/5 badanych) oraz do osób znajomych (ponad $1 / 3$ respondentów). 
Tabela 1. Ocena przesyłania erotycznych wiadomości tekstowych (\%)

\begin{tabular}{|l|c|c|c|}
\hline \multicolumn{1}{|c|}{ OCENA przesyłania wiadomości w zależności od ODBIORCY } & Pozytywna & Neutralna & Negatywna \\
\hline Do swojego chłopaka/dziewczyny & 71 & 25 & 4 \\
\hline Do swojego/ej eks & 3 & 18 & 79 \\
\hline Do znajomego/ej & 5 & 36 & 59 \\
\hline Do obcej osoby & 0 & 7 & 93 \\
\hline Do wielu osób & 1 & 5 & 94 \\
\hline Do nieograniczonej liczby osób & 0 & 7 & 93 \\
\hline
\end{tabular}

W kwestii przesyłania swoich zdjęć/filmów o charakterze seksualnym (tabela 2) respondenci byli bardziej zasadniczy niż w przypadku wiadomości; można zaobserwować tu znacznie mniej wyników pozytywnych, gdzie nadal najbardziej akceptowanym odbiorcą takich treści są osoby, z którymi tworzy się związek, ale aprobatę dla takiego postępowania wyraziło jedynie 2/5 ankietowanych. Część głosów pozytywnych przeszło tutaj do neutralnych, których odsetek wzrósł o 8\% w porównaniu z danymi w tabeli 1, a część do negatywnych, których jest o 22\% więcej (w sumie co czwarty badany źle ocenia przesyłanie takich zdjęć/filmów nawet do własnej dziewczyny lub chłopaka). Zmniejszyły się także odsetki odnoszące się do ocen pozytywnych i neutralnych w sytuacji, kiedy odbiorcą omawianych materiałów jest były/a partner/ka oraz osoba znajoma - oceniają to pozytywnie tylko pojedyncze osoby, a neutralnie mniej niż 1/10.

Sytuację, kiedy zdjęcia/filmy przesyła się do osoby obcej, do wielu odbiorców lub do nieograniczonej liczby osób, ankietowani niemal jednomyślnie oceniają w sposób negatywny.

Tabela 2. Ocena przesyłania swoich erotycznych zdjęć/filmów (\%)

\begin{tabular}{|l|c|c|c|}
\hline \multicolumn{1}{|c|}{ OCENA przesyłania zdjęć/filmów w zależności od ODBIORCY } & Pozytywna & Neutralna & Negatywna \\
\hline Do swojego chłopaka/dziewczyny & 39 & 33 & 26 \\
\hline Do swojego/-ej eks & 1 & 8 & 89 \\
\hline Do znajomego/ej & 2 & 9 & 87 \\
\hline Do obcej osoby & 1 & 0 & 97 \\
\hline Do wielu osób & 0 & 0 & 98 \\
\hline Do nieograniczonej liczby osób & 0 & 1 & 97 \\
\hline
\end{tabular}

Podsumowując dane $\mathrm{z}$ dwóch powyższych tabeli, można zauważyć, że w przypadku wiadomości tekstowych uzyskano 80 ocen pozytywnych, 98 neutralnych oraz 422 negatywnych. W przypadku zdjęć i filmów było to kolejno: 43 oceny pozytywne, 51 neutralnych i aż 494 negatywne. Co się tyczy różnic między wypowiedziami studentów w zależności od płci, to w odniesieniu do obu przypadków sekstingu więcej ocen negatywnych dotyczących partnerów obecnych i byłych oraz osób znajomych 
zaznaczyły kobiety. Mężczyźni wobec tych trzech grup odbiorców częściej wybierali oceny neutralne w przypadku przesyłania zdjęć lub filmów (oraz w sytuacji wysyłania znajomym erotycznych wiadomości). Pozostałe różnice były nieznaczne.

W kolejnych dwóch pytaniach chciano się dowiedzieć, czy płeć lub wiek nadawców ma wpływ na ocenę wysyłania materiałów o charakterze seksualnym. Dane zilustrowano na wykresie 7 oraz 8.

Większość ankietowanych (częściej kobiety) uważa, że płeć jest tu bez znaczenia, mniej niż 1/5 gorzej ocenia takie postępowanie u dziewcząt. Chłopców w tym aspekcie oceniają surowiej przede wszystkim respondenci płci męskiej (ponad 1/10).

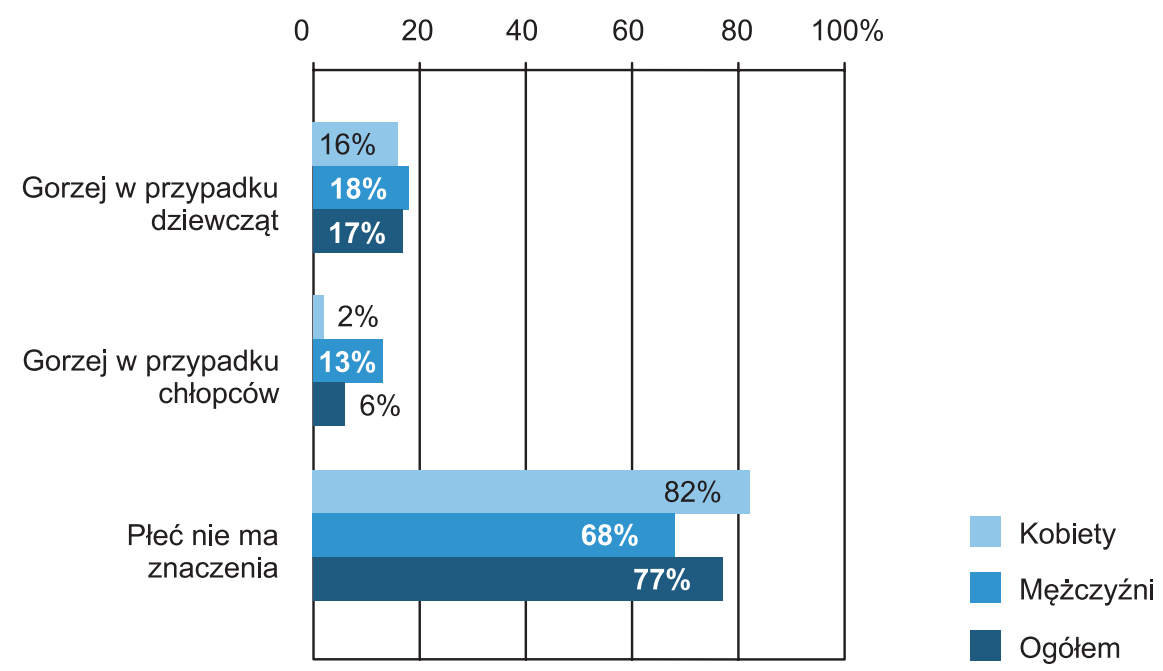

Wykres 7. Postrzeganie sekstingu ze wzgledu na płeć (\%)

Co się tyczy wieku, opinie badanych były podzielone (z niewielką przewagą głosów twierdzących, że aspekt ten ma znaczenie), zwłaszcza biorąc pod uwagę płeć ankietowanych. Większość mężczyzn uznało, że wiek nadawcy wpływa na to, jak oceniają przesyłanie materiałów o charakterze seksualnym, 1/3 była przeciwnego zdania. Głosy kobiet podzieliły się bardziej równomiernie - nieco więcej niż połowa odpowiedziała przecząco, mniej niż połowa - twierdząco. Prawie co trzeci respondent wskazał jako minimalną granicę wiekową 18 lat, blisko 1/10 - 15-17 lat, według dwóch badanych powinno to być 19 lat, a według jednego - 21. Dwie osoby nie odpowiedziały na to pytanie, a dwie dodały własne odpowiedzi (student: „nie powinno się tego robić wcale”; studentka: „zależy co widać na zdjęciach”. Powyższe dane ilustruje wykres 8. Warto dodać, że seksting noszący znamiona pornografii nie jest obecnie legalny w przypadku osób małoletnich (a nie tylko poniżej 15. r.ż.), czego młodzież nie zawsze jest świadoma ${ }^{14}$. Artykuł 202

${ }^{14}$ A. Pajewska, Ochrona małoletnich przed pornografia, INFOR 2014, https://www.infor.pl/ prawo/kodeks-karny/odpowiedzialnosc-karna/694607,Ochrona-maloletnich-przed-pornografia. html (dostęp: 28.09.2018). 
Kodeksu karnego mówi m.in.: „Kto w celu rozpowszechniania produkuje, utrwala lub sprowadza, przechowuje lub posiada albo rozpowszechnia lub prezentuje treści pornograficzne $\mathrm{z}$ udziałem małoletniego [...] podlega karze pozbawienia wolności od lat 2 do 12 ” (\$3); „Kto przechowuje, posiada lub uzyskuje dostęp do treści pornograficznych $\mathrm{z}$ udziałem małoletniego, podlega karze pozbawienia wolności od 3 miesięcy do lat 5 " $(\$ 4)^{15}$. Dodatkowo karalne jest utrwalanie wizerunku nagiej osoby lub osoby w trakcie czynności seksualnej, jeśli uzyskuje się to przemocą, groźbą lub podstępem, jak również rozpowszechnianie tego wizerunku bez jej zgody ${ }^{16}$. Konsekwencje są tu zatem wyraźnie określone.

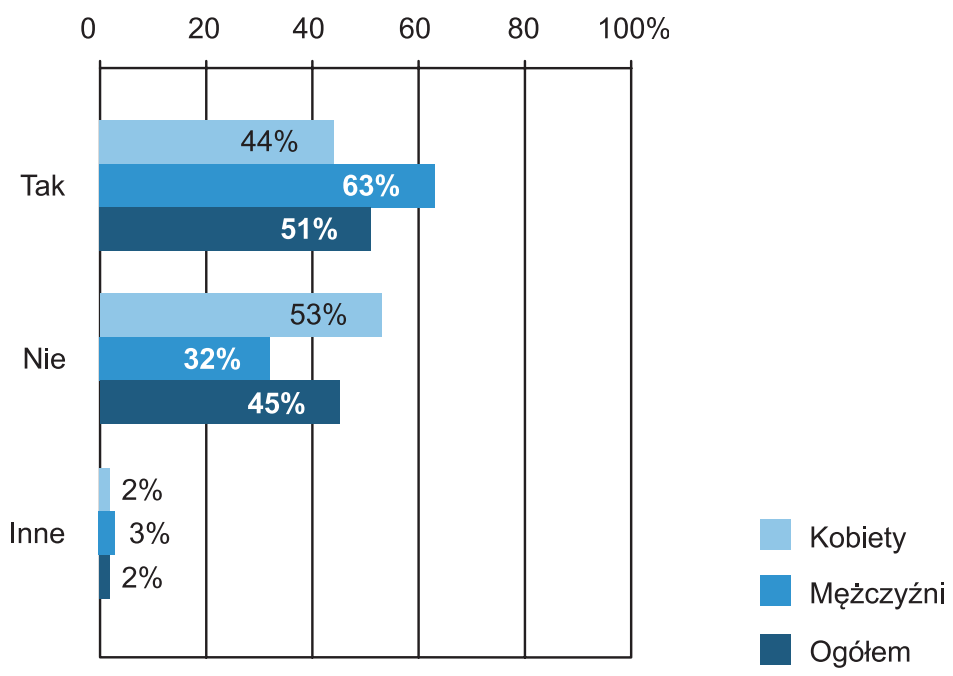

Wykres 8. Ocenianie sekstingu ze wzgledu na płeć (\%)

Następne zagadnienie dotyczyło tego, kto ma największy wpływ na to, w jaki sposób ankietowani oceniają seksting, i mieli to zaznaczyć w skali 0-3, gdzie 0 oznaczało żaden, 1 - mały, 2 - średni, 3 - duży. W poniższej tabeli przedstawiono średnie z tych danych. Można stwierdzić, że najwyższe noty uzyskali rówieśnicy, a więc niekoniecznie najbardziej kompetentne źródło wiedzy, aczkolwiek postawy wobec sekstingu nie są podyktowane tylko posiadanymi informacjami w tym zakresie, ale również kwestiami aksjologicznymi. To tłumaczy fakt, że na drugim miejscu znaleźli się rodzice (z wyższymi ocenami ze strony studentek), a zaraz za nimi wiara. Media w tym rankingu uplasowały się na ostatnim miejscu, co jest optymistyczną wiadomością, biorąc pod uwagę ich zalew niewłaściwymi treściami, demoralizującymi czy relatywizującymi wszystkie wartości, zwłaszcza we wszechobecnym dzisiaj, przede wszystkim w życiu młodych ludzi, Internecie. Trzy osoby nie odpowiedziały na to pytanie.

\footnotetext{
15 Kodeks karny, Przestępstwa przeciwko wolności seksualnej i obyczajności, 2019, art. 202.

${ }^{16}$ Kodeks karny, Przestępstwa przeciwko wolności, 2019, art. 191a.
} 
Tabela 3. Wpływ na ocenę sekstingu w skali 1-3

\begin{tabular}{|l|c|c|c|}
\hline \multicolumn{1}{|c|}{ Źródła wpływu } & Kobiety & Mężczyźni & Ogółem \\
\hline Rodzice & 1.7 & 1.4 & 1.6 \\
\hline Rówieśnicy & 2.0 & 1.6 & 1.8 \\
\hline Media & 1.3 & 0.8 & 1.1 \\
\hline Wiara & 1.5 & 1.5 & 1.5 \\
\hline
\end{tabular}

Wskazane źródła, które najbardziej wpływają na to, jak oceniają seksting respondenci (wykres 9), nie do końca pokrywają się z danymi uzyskanymi z odpowiedzi na kolejne pytanie. Nie było również jednolitych opinii pośród reprezentantów obu płci. Badani mieli wskazać, kto, ich zdaniem, powinien edukować o skutkach sekstingu (\%). Większość kobiet wskazała rodziców oraz szkołę. W typach mężczyzn zdecydowanie największą popularnością cieszyła się szkoła, którą również wybrała większość tej grupy, natomiast rodzice otrzymali 1/3 ich głosów. Za dydaktyczną rolą mediów tym razem opowiedział się co czwarty ankietowany, natomiast Kościół wybrało zaledwie kilka osób. Troje ankietowanych nie odpowiedziało na to pytanie, jeden student zaś podkreślił, że nie powinno się zwalniać użytkowników nowoczesnych technologii z samodzielnego myślenia, pisząc: „po co edukować, niech ludzie sami myślą!”.

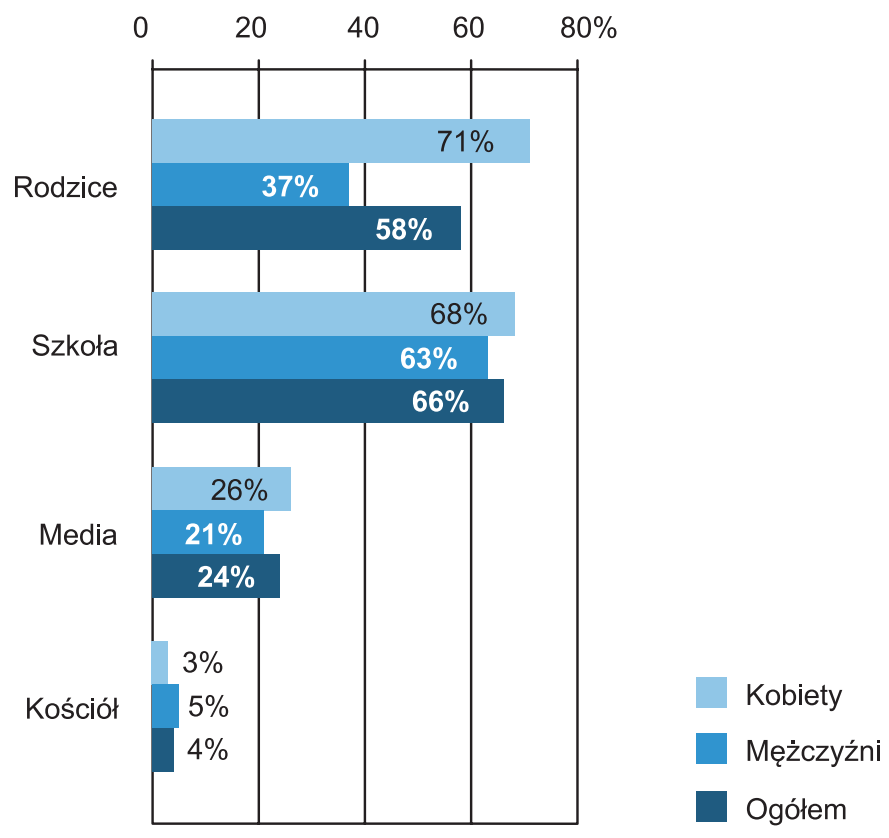

Wykres 9. Kto powinien edukować o skutkach sekstingu (\%)?

Opinię przytoczoną powyżej zdaje się podzielać większa liczba studentów, ponieważ na podsumowujące tę część badań pytanie o to, w jaki sposób powinno się 
przeciwdziałać sekstingowi, aż 1/4 odpowiedziała, że nie ma takiej potrzeby, przy czym odsetek myślących w ten sposób mężczyzn był pięciokrotnie wyższy niż kobiet (odpowiednio 6,5\% oraz 32\%). Niemała część respondentów wcale nie odpowiedziała na to pytanie (blisko 1/5, zbliżone proporcje pod względem płci). Pozostali, którzy wyrazili swoje zdanie (55\%), pisali głównie o tym, iż należy uświadamiać społeczeństwo, zwłaszcza dzieci i młodzież, o zagrożeniach związanych z sekstingiem. Takich ogólnikowych wypowiedzi typu „uświadamiać, „uczyć”, „pokazywać skutki” było najwięcej, sporo osób również podkreślało, że należy przeciwdziałać temu zjawisku, ale nie mają pomysłu na to, jak to zrobić. Reszta proponowała, by edukować poprzez media - kampanie społeczne, wywiady, filmy, spoty reklamowe; powinno się również nauczać o tym w szkołach i rozmawiać w domach rodzinnych.

\section{Podsumowanie i konkluzje}

Zdecydowana większość kobiet i niemal wszyscy mężczyźni uznali, że atrakcyjny wygląd ułatwia osiągnięcie sukcesu, przede wszystkim zawodowego oraz - w mniejszym stopniu - towarzyskiego. Własny wygląd jest ważny dla zdecydowanej większości badanych. Może zaskakiwać fakt, iż nie wystąpiły tu specjalne różnice pomiędzy wynikami uzyskanymi od kobiet i mężczyzn. Potwierdza to obiegowe opinie o tym, że mężczyźni coraz bardziej dbają o swój wygląd zewnętrzny, co jest niewątpliwie charakterystyczne dla czasów współczesnych. Również wygląd partnera/ki większość określiła jako ważny, aczkolwiek można zauważyć, że kobiety są nieco mniej wymagające w stosunku do osób, z którymi są w związku, aniżeli wobec siebie samych, natomiast odwrotnie ma się sprawa u mężczyzn.

Podejście do seksualności nie jest jednolite. Najwięcej osób uznało, że powinna być ona zarezerwowana dla partnera/ki, niezależnie od ślubu. $\mathrm{Na}$ drugim miejscu u kobiet była teza, według której seksualność to sprawa prywatna, przypisana jedynie do małżeństwa. Druga pozycja u mężczyzn to zdanie dopuszczające dzielenie się seksualnością ze swoim otoczeniem, jednak w pewnych granicach. Opinie kobiet wydają się być nieco bliżej nurtu tradycyjnego, aczkolwiek zaburza je grupka studentek, które częściej niż ich koledzy traktują seksualność zupełnie przedmiotowo. Jednak w obu przypadkach jest to teza najmniej popularna.

Większość kobiet nie ogląda zdjęć/filmów pornograficznych, a pozostałe robią to sporadycznie. Pośród mężczyzn odpowiedź przeczącą wybrała niespełna $1 / 10$, a co piąty robi to często. Opinie na temat takich materiałów również są podzielone, największa grupa pośród osób, które udzieliły tu odpowiedzi, ocenia je neutralnie lub ambiwalentnie, na drugim miejscu były opinie negatywne, na trzecim zaś pozytywne, aczkolwiek podsumowując, można powiedzieć, że oceny kobiet są tu surowsze.

Co się tyczy oceny sekstingu, respondenci są bardziej wyrozumiali w przypadku przesyłania wiadomości tekstowych aniżeli zdjęć czy filmów. Większość z nich ocenia pozytywnie takie postępowanie w odniesieniu do osoby, z którą się jest w związku, 
a co piąty badany - także w odniesieniu do byłych partnerów, dodatkowo ponad 1/3 ocenia dobrze również tego typu korespondencję z osobami znajomymi. Jeśli chodzi o zdjęcia i filmy, to ocen pozytywnych było około dwóch, trzech razy mniej, jednakże wciąż są to liczące się głosy, które mogą niepokoić, zwłaszcza w sytuacji, kiedy dotyczy to osób, z którymi nie ma się intymnej relacji, aczkolwiek w każdym przypadku nadawca takich treści musi liczyć się z potencjalnymi zagrożeniami. Nieco uspokaja fakt, że przynajmniej w odniesieniu do przesyłania jakichkolwiek erotycznych materiałów do pozostałych grup odbiorców (osób obcych, wielu osób, nieograniczonej liczby osób) respondenci byli w zdecydowanej większości krytyczni. Jednakże młodzi ludzie nie zawsze zdają sobie sprawę $z$ efektu kuli śnieżnej ${ }^{17}$, jaki może towarzyszyć przesłaniu intymnych materiałów do osoby teoretycznie bliskiej (czy nawet samemu faktowi posiadania takich treści).

Większość respondentów uważa, że płeć nadawcy materiałów o tematyce seksualnej nie ma znaczenia, aczkolwiek blisko co piąty ocenił gorzej w tym względzie dziewczęta, a jeszcze mniejsza grupa, ze zdecydowaną przewagą mężczyzn, uznała, że gorzej ocenia tu chłopców. Jeśli chodzi o wiek, rozbieżności były większe, ponad połowa badanych stwierdziła, że ten aspekt jest istotny, i przeważali tu mężczyźni, natomiast wśród osób, które odpowiedziały przecząco, było więcej kobiet.

Wydaje się, że największy wpływ na to, w jaki sposób młodzi ludzie oceniają seksting, mają ich rówieśnicy. Wychowanie ze strony rodziców niestety zajęło w tym rankingu drugą pozycję, następna była wiara, a dopiero na ostatnim miejscu - środki masowego przekazu. To ostatnie wydaje się być dobrą wiadomością w kontekście nierzadkiego bezkrytycznego odbioru treści medialnych.

Według większości badanych o zagrożeniach związanych z sekstingiem powinna edukować szkoła, a następnie rodzice (tu dominowały głosy kobiet). Co czwarty student wyraził potrzebę takiej edukacji w mediach. Rola Kościoła, zdaniem ankietowanych, jest w tym przypadku marginalna. Teoretycznie to ostatnie może stać w sprzeczności z wynikami świadczącymi o tym, że wiara odgrywa niemałą rolę w ocenie sekstingu przez młodych ludzi, ale nie musi - jeśli się założy, że pierwszymi nauczycielami, także w tym względzie, są rodzice.

Jednocześnie jednak co czwarty ankietowany nie widzi konieczności przeciwdziałania sekstingowi, część nie wyraziła tu swojego zdania, a ponad połowa uznała, iż jest taka potrzeba i głównie powinno tu się postawić na edukację społeczeństwa o potencjalnych zagrożeniach związanych z tym zjawiskiem, ze szczególnym uwzględnieniem młodego pokolenia. Przede wszystkim można wykorzystać w tym celu media, ale powinno się również uświadamiać w tym względzie w szkole i w domu.

Badana grupa była niewielka, dlatego do uzyskanych danych należy podchodzić $\mathrm{z}$ dużą ostrożnością. Jednak pochodzące od ankietowanych informacje umożliwiły

${ }_{17}$ D. Siegle, Cyberbullying and Sexting: Technology Abuses of the 21st Century, „Gifted Child Today", nr 2/2010, s. 15. 
przybliżenie pewnych tendencji odnoszących się do młodych ludzi i rzuciły światło na ich postawy wobec omawianego tematu. Pozwalają również dostrzec aspekty wymagające zweryfikowania lub pogłębienia w planowanych kolejnych obszerniejszych badaniach.

Odpowiedzi respondentów nie zawsze były spójne, jednak nie jest to zaskakujące zjawisko, biorąc pod uwagę fakt, że byli to bardzo młodzi ludzie, których postawy i opinie jeszcze nie są w pełni ukształtowane. Do tego dochodzi kwestia rozbieżności między deklaracjami a faktycznymi działaniami. Ponadto tematy oscylujące wokół wartości, a niewątpliwie takim jest seksting, zawsze są trudne i pełne niuansów. To oczywiście nie oznacza, że nie można i nie należy ich podejmować. Wierzę, że zwłaszcza we współczesnej rzeczywistości, należy szeroko badać problemy, które poza kwestiami związanymi $\mathrm{z}$ bezpieczeństwem i/lub zagrożeniami, nawiązują do zawsze ważnej sfery aksjologicznej.

\section{Bibliografia}

Bereźnicka M., Znajomość i źródła wiedzy studentów Bezpieczeństwa Narodowego o zagrożeniach związanych zsekstingiem, „Annales Universitatis Paedagogicae Cracoviensis, Studia de Securitate", nr 8/2018.

Bębas S., Sexting - nowe zagrożenie wśród dzieci i młodzieży, „Labor et Educatio”, nr 3/2015.

Featherstone M., Ciało w kulturze konsumpcyjnej, [w:] M. Szpakowska (red.), Antropologia ciała. Zagadnienia i wybór tekstów, Wydawnictwo Uniwersytetu Warszawskiego, Warszawa 2008.

Femiak J., Rymarczyk P., Ciało jako temat narracji kultury masowej i narracji wewnętrznej, „Rozprawy Naukowe AWF we Wrocławiu”, nr 49/2015.

Grabau A., Seksting - nastoletnia pornografia, „Tygodnik Przegląd”, 11.03.2012, https://www.tygodnikprzeglad.pl/seksting-nastoletnia-pornografia/ (dostęp: 25.07.2018).

Horn T., Sexting: The Grownup's Little Book of Sex Tips for Getting Dirty Digitally, Fair Winds Press, 2016.

Johnson Z., Miley Cyrus Makes Time's 100 Most Influential People; Dolly Parton Explains Her "Drastic" Makeover, https://www.eonline.com/news/535222/mileycyrus-makes-time-s-100-most-influential-people-dolly-parton-explains-her -drastic-makeover (dostęp: 15.10.2018).

Karsay K., Knoll J., Matthes J., Sexualizing Media Use and Self-Objectification: A Meta-Analysis, „Psychology of Women Quarterly”, nr 42(1)/2017.

Kirwil L., Zdrodowska A., Zagrożenia online: klasyfikacja i rozpowszechnienie wśród dzieci w wieku 9-16 lat. Dane z paneuropejskich badań EU Kids Online, referat 
na konferencji „Między Dniem Ochrony Danych Osobowych a Dniem Bezpiecznego Internetu", OEIiZK, Warszawa 4.02.2015.

Kodeks karny, Przestępstwa przeciwko wolności seksualnej i obyczajności oraz Przestępstwa przeciwko wolności, 2019.

Martinez-Prather K., Vandiver D.M., Sexting among Teenagers in the United States: A Retrospective Analysis of Identifying Motivating Factors, Potential Targets, and the Role of a Capable Guardian, „International Journal of Cyber Criminology", nr 8(1)/2014.

McCabe M., Butler K., Watt C., Media Influences on Attitudes and Perceptions Toward the Body Among Adult Men and Women, „Journal of Applied Biobehavioral Research", nr 12(2)/2007.

Melosik Z., Tożsamość, ciało i władza w kulturze instant, Oficyna Wydawnicza Impuls, Kraków 2010.

Netzley P.D., Teens and Sexting. Teen Choices, Reference Point Press, San Diego CA 2015. Pajewska A., Ochrona małoletnich przed pornografia, INFOR 2014, https://www.infor. $\mathrm{pl} /$ prawo/kodeks-karny/odpowiedzialnosc-karna/694607,Ochrona-maloletnich-przed-pornografia.html (dostęp: 28.09.2018).

Siegle D., Cyberbullying and Sexting: Technology Abuses of the 21st Century, „Gifted Child Today", nr 2/2010.

Szmyd J., Medialny obraz rzeczywistości jako główna orientacja poznawcza i praktyczna $w$ świecie, [w:] K. Pokorna-Ignatowicz (red.), Medialny obraz rodziny i płci, Oficyna Wydawnicza AFM, Kraków 2012.

Wójcik A., Makaruk K., Seksting wśród polskiej młodzieży, FDN, 2014, http://fdds.pl/ wp-content/uploads/2016/05/Wojcik Makaruk Seksting wsrod polskiej mlodziezy.pdf (dostęp: 27.09.2018).

\section{Sexting and other issues related to sexuality: The opinions of young women and men}

Abstract: The article discusses the issue of sexuality, which has changed to a large extent through the development of modern technologies, especially as far as young people are concerned. The popularisation of the Internet and mobile telephony has encouraged more people to share private and even intimate photos or videos with an unlimited number of recipients. The author introduces a report from an empirical survey, aimed at examining the opinions of young women and men concerning sexuality and sexting.

Keywords: sexuality, sexting, opinions, attitudes, Internet threats

About the author: Małgorzata Bereźnicka - DSc, Prof. of the Pedagogical University in Krakow. Research interests are related to: social pedagogy, family pedagogy, values, education for safety, communication, network security, social pathologies. 


\title{
Edukacja muzealna w praktyce szkolnej - wyzwania dydaktyczne
}

DOI: 10.25312/2083-2923.15/2019_04ac

\begin{abstract}
Streszczenie: W prezentowanym artykule przedmiotem refleksji dydaktycznej jest edukacja muzealna. Zastosowana metoda badań to autobiografia tematyczna. W badaniach uczestniczyło 27 nauczycieli wyłonionych na podstawie wyboru rekomendacyjnego. Analizie poddane zostały te fragmenty wypowiedzi autobiograficznych nauczycieli, które wiążą się bezpośrednio $\mathrm{z}$ ich pracą zawodową, z realizacją edukacji muzealnej w systemie kształcenia szkolnego. W prezentacji wyników badań własnych opisane zostały dwa pola tematyczne. Pierwsze to uwagi nauczycieli na temat powiązań edukacji muzealnej z realizacją podstawy programowej kształcenia ogólnego oraz drugie pole tematyczne związane z uczniem jako głównym odbiorcą i bezpośrednim uczestnikiem edukacji muzealnej.
\end{abstract}

Słowa kluczowe: edukacja muzealna, edukacja formalna, nauczyciel, uczeń, podstawa programowa kształcenia ogólnego

\section{Wprowadzenie}

Treści zaprezentowane w artykule stanowią fragment szerszych analiz nad modelami edukacji kulturowej w szkolnej przestrzeni edukacji formalnej. Badania te prowadzone były w ramach programu „Bardzo Młoda Kultura” finansowanego przez Narodowe Centrum Kultury w latach 2016-2018 . Artykuł składa się z trzech części. Rozpoczyna go krótka analiza teoretyczna wprowadzająca w problematykę edukacji

Agata Cabała - doktor nauk humanistycznych w zakresie pedagogiki. Starszy wykładowca w Zakładzie Dydaktyki Ogólnej i Pedeutologii na Wydziale Pedagogiki i Psychologii Uniwersytetu Śląskiego w Katowicach. Koordynator z ramienia wydziału współpracy z Muzeum Śląskim w Katowicach i Regionalnym Instytutem Kultury w Katowicach. Badawczo interesuje się systemowymi rozwiązaniami dla łącznia edukacji szkolnej z pozaszkolną.

1 Autorka jest koordynatorem ds. oświaty projektu operatorkultury.pl w województwie śląskim, realizowanym przez Regionalny Instytut Kultury w Katowicach. 
muzealnej i jej powiązań z edukacją szkolną. Następnie opisano założenie metodologiczne badań, by w efekcie zaprezentować wyniki badań własnych.

\section{Edukacja muzealna - wybrane zagadnienia teoretyczne}

Edukacja muzealna wchodzi w zakres badań dydaktyki ogólnej jako nauki o nauczaniu i uczeniu się - nauki zajmującej się zamierzonymi i świadomie podejmowanymi czynnościami, które mają na celu ukształtowanie osobowości uczestnika działań edukacyjnych ${ }^{2}$. Edukacja muzealna jest działaniem zamierzonym, świadomym, podejmowanym z określoną intencją edukacyjną ${ }^{3}$. Obejmuje wszystkie grupy wiekowe, od najmłodszych dzieci przychodzących do muzeum z rodzicami, po osoby w zaawanasowanym wieku, odwiedzające muzeum zarówno indywidualnie, jak i grupowo, np. w ramach zajęć Uniwersytetu Trzeciego Wieku. W tym opracowaniu interesują autorkę związki między muzeum i szkołą, między edukacją nieformalną i formalną ${ }^{4}$.

„Żyjemy w czasach bezprecedensowej muzealizacji świata. Jest to jedno z najbardziej globalnych, a zarazem indywidualnych zjawisk początku XXI w., pisze Dorota Folga-Januszewska we wstępie książki Muzeum: fenomeny i problemy ${ }^{5}$. Rozpatrując w perspektywie temporalnej przemiany, jakim podlegały, podlegają i będą podlegać muzea, autorka stawia w zakończeniu ciekawą tezę. Na pytanie, dla kogo są współczesne muzea?, odpowiada: dla pojedynczych, określonych osób, dla zidentyfikowanego odbiorcy mającego swe konkretne wymagania ${ }^{6}$. W kontekście szkolnym, bo ten nas tutaj interesuje, warto przemyśleć pomysł spersonalizowania oferty edukacyjnej skierowanej do konkretnego, zidentyfikowanego podmiotu działań, do konkretnej klasy, grupy przedszkolnej, grupy uczniów o specjalnych potrzebach edukacyjnych przychodzących do muzeum z nauczycielem w ramach zajęć szkolnych. Propozycja ta, obok wskazań dydaktycznych opracowanych przez interdyscyplinarny zespół badaczy, Jolantę Kruk i Grzegorza Karwaszaㄹ, w pracach nad muzealnymi strategiami edukacyjnymi, wydaje się ciekawym pomysłem w obszarze poszukiwań nowych rozwiązań edukacyjnych przybliżających dwie ważne instytucje edukacyjne - muzea

${ }^{2}$ W. Kojs, Działanie jako kategoria dydaktyczna, Uniwersytet Śląski w Katowicach, Katowice 1994, s. 7.

${ }^{3} \mathrm{Na}$ świadome (intencjonalne) działanie odróżniające edukację od upowszechnienia, popularyzacji zawraca uwagę Marcin Szeląg w opracowaniu: Edukacja głupcze! Zadania muzeum na początku XXI wieku, [w:] Muzeum XXI wieku - teoria i praxis, Muzeum Początków Państwa Polskiego, Gniezno 2010, s. 179.

${ }_{4}$ Zob. M. Allard, S. Boucher, Éduquer au musée. Un modele théorique de pédagogie muséale, Hurtubise HMH Ltée, Montréal 1998, s. 85-133; ciż, Le musée et l’école, Hurtubise HMH Ltée, Montréal 1991, s. 33-88.

${ }^{5}$ D. Folga-Januszewska, Muzeum: fenomeny i problemy, Universitas, Warszawa 2015, s. 7.

6 Tamże, s. 136.

${ }^{7}$ G. Karwasz, J. Kruk, Idee i realizacje dydaktyki interaktywnej - wystawy, muzea i centra nauki, Wydawnictwo Naukowe Uniwersytetu Mikołaja Kopernika, Toruń 2012, s. 202. 
i szkoły ${ }^{8}$. Wciąż bowiem aktualna wydaje się konstatacja Tadeusza Gołaszewskiego umieszczona w książce Dziecko w muzeum ponad 50 lat temu: „Należy sobie jednakże równocześnie zdawać sprawę, iż jesteśmy dopiero na początku systematycznej, ścisłej współpracy muzeum ze szkołą, że pozostaje tu wiele do zrobienia"9.

O wadze podejmowanych kwestii świadczyć może fakt, iż w Raporcie Strategia Rozwoju Muzealnictwa edukacja i działalność edukacyjna muzeów wybrane zostały jako swego rodzaju „pola strategiczne”, na których sprawdzano zasadność i skuteczność założeń samej strategii i możliwość jej realnego wykorzystania przez muzea i organizatorów muzeów ${ }^{10}$, przy czym zagadnienia współpracy muzeów z edukacją formalną stanowiły w Strategii jeden z obszarów problemowych poruszanych w obrębie szeroko pojętej edukacji otwartej. Tymczasem wątek ten był jednym z poważniejszych w dyskusji podejmowanej przez edukatorów muzealnych w analizach Raportu o stanie edukacji muzealnej w Polsce ${ }^{11}$. Problematyka dyskusji wyznaczona została przez pragmatykę muzealną, jak pisze w komentarzu Marcin Szeląg, na którą składa się częsta praca z nauczycielami i grupami szkolnymi uczestniczącymi w lekcjach muzealnych $^{12}$. Jeżeli praca edukatorów muzealnych ukierunkowana jest w głównej mierze na pracę z uczniem, mógłby to być wskaźnik dobrej współpracy na linii muzeum szkoła. Problem leży jednak niejednokrotnie nie w liczbie lekcji muzealnych, a pomyśle na systemowe rozwiązania włączenia edukacji muzealnej w system kształcenia szkolnego, w podstawy programowe i programy nauczania na wszystkich stopniach edukacji ${ }^{13}$. Z punktu widzenia systemowego ważne jest to, aby i nauczyciel, i edukator muzealny dostrzegli specyfikę i walory cyklicznych, a nie jednorazowych zajęć uczniów w muzeum ${ }^{14}$. Aby muzeum nie było traktowane przez nauczycieli jako cel szkolnej wycieczki i „zapychacz” dni, w których prowadzone są egzaminy ${ }^{15}$, ale aby treści muzealne wchodziły w treść zajęć szkolnych, stanowiły naturalną część procesu dydaktycznego, łącznie z ewaluacją i oceną postępów pracy uczniów, aby ich wizyty

${ }^{8}$ Zob. O. Gałuszek, Po co szkole muzeum, po co muzeum szkoła? O edukacji muzealnej z perspektywy prowadzacego zajęcia nauczyciela, [w:] M. Szeląg (red.), Edukacja muzealna w Polsce. Sytuacja, kontekst, perspektywy rozwoju. Raport o stanie edukacji muzealnej w Polsce, Narodowy Instytut Muzealnictwa i Ochrony Zbiorów, Muzeum Pałac w Wilanowie, Warszawa 2012, s. 145.

9 T. Gołaszewski, Dziecko w muzeum, Nasza Księgarnia, Warszawa 1967, s. 89.

${ }^{10}$ Raport Strategie Rozwoju Muzealnictwa. Założenia programowe, Narodowy Instytut Muzealnictwa i Ochrony Zbiorów, Warszawa 2012, s. 10-12.

${ }^{11}$ M. Szeląg, Edukacja muzealna i muzea w opiniach uczestników seminariów z cyklu „Raport o stanie edukacji muzealnej w Polsce. Suplement”, [w:] M. Szeląg (red.), Raport o stanie edukacji muzealnej. Suplement. Część 1, Universitas, Kraków 2014, s. 77.

12 Tamże.

${ }_{13}$ Zob. R. Pater, Edukacja muzealna w Niemczech, [w:] M. Szeląg (red.), Edukacja muzealna w Polsce..., s. 207.

${ }^{14}$ O. Gałuszek, dz. cyt., s. 149.

${ }^{15}$ Raport Strategie Rozwoju Muzealnictwa..., s. 114. 
w muzeum wynikały nie tylko z kalendarza roku szkolnego, ale z rozkładu szkolnego programu nauczania ${ }^{16}$.

\section{Metodologia badań}

Prezentowane badania, jak już wcześniej wspomniano, stanowiły część większego projektu badawczego. Prowadzone były w 2017 roku, a ich celem była rekonstrukcja modeli edukacji kulturowej w przestrzeni kształcenia formalnego ${ }^{17}$. Objęci nimi zostali nauczyciele wykazujący aktywność w zakresie realizacji edukacji kulturowej w swojej pracy zawodowej, których działania nierzadko skutkują sukcesem. Nauczyciele wyłonieni zostali do badań za pomocą wyboru rekomendacyjnego, dzięki współpracy z Wojewódzkimi Ośrodkami Metodycznymi w Rybniku, Częstochowie, Katowicach i Bielsku-Białej oraz z Regionalnym Ośrodkiem Szkolno-Metodycznym METIS w Katowicach. Dobór nauczycieli do badań trwał do momentu uzyskania teoretycznego nasycenia badanych przypadków ${ }^{18}$. Ostatecznie w badaniach uczestniczyło 27 osób, w tym 85,2\% kobiet. W większości przypadków, bo aż 81,5\% są to nauczyciele mieszkający i pracujący w mieście oraz nauczyciele, prawie $41 \% \mathrm{z}$ nich, ze stażem pracy od 21 do 30 lat. Grupa badawcza okazała się mocno zróżnicowana pod względem miejsca pracy i realizowanych przedmiotów nauczania. W jej skład wchodzili zarówno nauczyciele edukacji przedszkolnej, wczesnoszkolnej, gimnazjum, jak również średniego ogólnokształcącego i technicznego oraz zawodowego etapu kształcenia. Największy odsetek stanowili nauczyciele pracujący w szkole podstawowej (22,2\% ogółu badanych). Niektóre osoby wskazały dwa lub więcej miejsc pracy, na przykład: szkoła podstawowa i gimnazjum. Wśród realizowanych przez nauczycieli przedmiotów znalazły się bardzo różnorodne, od języka polskiego, historii po wczesne wspomaganie rozwoju dziecka z dysfunkcjami, rewalidację, logopedię i arteterapię. Wydaje się, iż uzyskana próba badawcza zapewniła zmienność w obrębie pola badawczego, ukazując różnorodność doświadczeń biograficznych osób badanych, ich sposobu myślenia, wyrażanych poglądów, przywołanych sytuacji i zdarzeńn ${ }^{19}$.

${ }^{16}$ W roku szkolnym 2017/2018 Muzeum Narodowe w Krakowie uruchomiło program „Zmierz się z kulturą", w którym zaprosiło do rocznej współpracy wybrane w drodze konkursu szkoły. Autorka wraz z Anną Grzelak, kierownikiem programu dla szkół i nauczycieli MN w Krakowie badała efekty działania programu. Materiały są w opracowaniu.

${ }_{17}$ Rezultatem badań jest książka: A. Cabała, V. Rodek, W poszukiwaniu modeli edukacji kulturowej. Aktywność nauczycieli i jej uwarunkowania w przestrzeni edukacji formalnej, Regionalny Instytut Kultury w Katowicach, Katowice 2017.

${ }_{18}$ I.K. Helling, Metoda badań biograficznych, [w:] G. Włodarek, M. Ziółkowski (red.), Metoda biograficzna w socjologii, PWN, Warszawa-Poznań 1990, s. 22.

19 Szczegółowy opis badań: A. Cabała, V. Rodek, dz. cyt., s. 31-48. 
W prezentowanych badaniach wykorzystano metodę biografii podmiotowej, autobiografii $^{20}$, w której autorzy-nauczyciele byli jednocześnie podmiotami opisywanych wydarzeń. Osoby badane opowiadały historię swojego życia w pierwszej osobie, a źródłem wiedzy były ich wspomnienia i przeżycia zakodowane w pamięci. Ze względu na cele badań zastosowano autobiografię tematyczną ${ }^{21}$, autobiografię inspirowaną, w której nauczyciele na prośbę badacza opisywali swoje życie w kontekście doświadczeń związanych z edukacją kulturową ${ }^{22}$.

Wypowiedzi nauczycieli na temat muzeów, edukacji muzealnej są tym bardziej cenne, że muzea przywołane zostały przez nich spontanicznie, jako naturalny element ich doświadczeń związanych z edukacją kulturową. W niniejszym opracowaniu analizie poddane zostaną te fragmenty wypowiedzi nauczycieli, które wiążą się bezpośrednio z ich pracą zawodową, z realizacją edukacji muzealnej w systemie kształcenia szkolnego.

Wśród obszarów problemowych pojawiły się następujące: edukacja muzealna jako czynnik wspomagający nauczyciela w realizacji podstawy programowej kształcenia ogólnego, w tym organizacja pracy szkoły, cele i rezultaty edukacji muzealnej, edukacja muzealna jako element wycieczek szkolnych, edukacja muzealna w pracy wychowawczej; muzea wirtualne w pracy na lekcji; praca z wystawą jako narzędzie edukacyjne; uczeń w edukacji muzealnej.

W prezentacji wyników badań własnych opisane zostaną te pola tematyczne, które wydawały się wiodące w wypowiedziach badanych nauczycieli. Pierwsze to uwagi nauczycieli na temat powiązań edukacji muzealnej z realizacją podstawy programowej kształcenia ogólnego oraz drugie pole tematyczne związane z uczniem jako głównym odbiorcą i bezpośrednim uczestnikiem edukacji muzealnej.

\section{Edukacja muzealna jako czynnik wspomagający nauczyciela w realizacji podstawy programowej kształcenia ogólnego. Prezentacja wyników badań}

Szkoła i muzeum to dwie różne instytucje edukacyjne. Każda ma swoją specyfikę i jedna nie może zastępować drugiej. Tak oczywiste stwierdzenie warto wypowiedzieć w kontekście dyskusji i debat toczących się w dużej mierze wśród edukatorów muzealnych na temat współpracy muzeum ze szkołą. Obowiązek realizacji podstawy programowej spoczywa na nauczycielu. Edukator muzealny może wspomagać

${ }^{20}$ D. Lalak, Życie jako biografia. Podejście biograficzne w perspektywie pedagogicznej, Wydawnictwo Żak, Warszawa 2010, s. 113.

${ }^{21}$ Por. I.K. Helling, dz. cyt., s. 5.

${ }^{22}$ Edukacja kulturowa za Martą Kosińską zdefiniowana została jako proces przygotowania do bardziej aktywnego, świadomego, często też krytycznego uczestnictwa w kulturze. Zob. M. Kosińska, hasło „edukacja kulturowa”, http://cpe.poznan.pl/dictionary/edukacja-kulturowa/ (dostęp: 2.10.2018). 
nauczyciela w tym zadaniu ${ }^{23}$. Podstawa programowa kształcenia ogólnego określa cele i zadania w zakresie realizacji poszczególnych przedmiotów nauczania, a także pracy wychowawczej szkoły. Stwierdzenie to wydaje się o tyle istotne, że znacznie poszerza pole współpracy nauczycieli z edukatorami muzealnymi. Wizyty uczniów w muzeum mogą wiązać się nie tylko z realizacją treści z zakresu języka polskiego, historii czy plastyki, czyli z treści przedmiotowych, ale również z realizacją programu wychowawczego czy też szkolnego programu profilaktycznego. Są to programy oparte na preambule podstawy programowej, które formułowane są jako dokumenty wewnątrzszkolne, a to oznacza, że tworzone są przez zespół nauczycieli w odniesieniu do potrzeb i założeń danej szkoły. Wątek wychowawczy we współpracy nauczycieli z muzeami pojawił się w następujących kontekstach:

Jako wychowawca klasy dbałam o to, by uczniowie regularnie odwiedzali muzea i korzystali z oferty edukacyjnej tych palcówek. Szczególnie cenna była dla mnie współpraca z Muzeum Historii Katowic [...]. Co roku w plany pracy wychowawcy klasowego włączałam działania mające na celu rozwijanie u uczniów umiejętności odbioru różnych dzieł sztuki. W każdym kwartale miało miejsce wyjście z uczniami do muzeum, kina czy teatru (nauczycielka języka polskiego i zajęć komputerowych).

Szczególnie interesująca jest wypowiedź jednej z nauczycielek, która wspomina pracę wychowawczą w Zespole Szkół Odzieżowych:

Prowadziłam lekcje dotyczące dobrego wychowania (podawania ręki, wstawania podczas rozmowy ze starszą od nas osobą etc.). II etap stanowiło spotkanie z malarstwem. Odwiedzałam z uczniami BWA czy Muzeum Śląskie. Uczyłam moich podopiecznych swobodnie wyrażać opinie o obrazach, mówić o wrażeniach, jakie wywoływały. To było jak odkrywanie nowych lądów, dziewiczych wysp. Cudowne doświadczenie, bo przecież przyszli krawcy mieli w sobie artystyczne dusze, czasami jeszcze nieodkryte (nauczycielka języka polskiego).

Jest to o tyle ciekawa wypowiedź, że dotyczy szkoły zawodowej, czyli szczebla kształcenia rzadko opisywanego jako przykład realizacji edukacji muzealnej, to po pierwsze. Po drugie, opisuje pracę wychowawczą realizowaną poprzez edukację kulturową, edukację muzealną z młodzieżą z biednych rodzin, w których kultura wysoka nie stanowiła wartości, jak podkreśliła w wypowiedzi nauczycielka.

Cele wychowawcze realizowane są również w trakcie wycieczek szkolnych, w których muzea pojawiają się niejednokrotnie jako element obowiązkowy w karcie wycieczki, przy czym „wydarzenie takie każdorazowo powinno być przedmiotem dyskusji z młodzieżą zarówno przed jak i po udziale w nim”, jak pisze nauczyciel języka angielskiego i matematyki. Co warte zauważenia, jedna z badanych nauczycielek języ-

${ }^{23}$ Zob. G. Czetwertyńska, Szkoła i muzeum - spotkanie w pół drogi, [w:] M. Szeląg (red.), Edukacja muzealna w Polsce..., s. 291-296. 
ka polskiego pisze o swoich przygotowaniach do zwiedzania wystaw z uczniami: „byłam w Krakowie i Katowicach, przygotowałam karty pracy dla uczniów, część przekazanych wiadomości wykorzystałam później w sprawdzianie wiedzy”. Jeżeli w artykule podejmowane są próby spojrzenia na powiązania edukacji muzealnej z edukacją szkolną, to ten fragment wypowiedzi nauczycielki wydaje się nad wyraz ważny, ponieważ pokazuje, jak kluczową rolę odgrywa nauczyciel w budowaniu spójnego obrazu wiedzy w umysłach uczniów. Edukator muzealny może wspomagać nauczyciela w tym zadaniu. W tym miejscu warto zwrócić uwagę na jeszcze jeden ważny wątek badawczy. Środkami realizacji zapisów podstawy programowej są treści kształcenia. Cele podstawy programowej realizować możemy, opierając się zarówno na treściach ujętych w systemach znakowych (np. treściach podręcznika), jak i treściach pochodzących z bezpośredniego poznawania rzeczywistości przyrodniczej, społecznej, kulturowej ${ }^{24}$. Będąc poza terenem klasy, szkoły, przebywając w instytucji kultury, uczeń zapoznaje się z treściami kształcenia, które przyczyniają się do realizacji założeń edukacji szkolnej. Jest to o tyle ważne ustalenie badawcze, że nadaje edukacji muzealnej należną mu rangę w edukacji szkolnej. Świadomość wagi tego typu treści mają również nauczyciele, którzy podkreślają wartość bezpośredniego poznania, przeżycia, kontaktu z dziełem sztuki:

Zobaczenie dzieł sztuki w muzeach, podczas wystaw, wzbogacone słowem przewodnika, pozostawia głębszy ślad niż wertowanie stron w albumach czy w telefonach. Uważam, że koniecznym elementem edukacji kulturowej jest bezpośredni kontakt ze sztuką na odpowiednim poziomie (nauczycielka języka polskiego).

Przy czym należy tu pokreślić ocenę przez nauczycieli wartości propozycji z zakresu edukacji kulturowej kierowanych do uczniów. Propozycje te muszą być na wysokim poziomie. Dobitnie wyraziła to jedna z nauczycielek:

Zazwyczaj korzystałam z zaproszeń na spektakle szkolne organizowane w domach kultury, nazywam to takimi „,szkolnymi spędami”. Łatwo, szybko, wygodnie można zaliczyć edukację kulturalną. Szybko zrezygnowałam z takiej formy ponieważ czasami miałam wrażenie, że zniechęcają one do sztuki zamiast zachęcać (nauczycielka języka polskiego i wiedzy o kulturze).

Wypowiedź ta odnosi się do spektakli szkolnych, jednak z całą pewnością można ją uogólnić do wszelkich propozycji z zakresu edukacji kulturowej, w tym edukacji muzealnej kierowanej przez instytucje kultury do szkół. Na jakość oferty kulturalnej kierowanej do dzieci i młodzieży zwraca uwagę Renata Pater, charakteryzując edukację muzealną w Niemczech. Autorka podkreśla przy tym istotną rolę muzeów, któ-

${ }^{24}$ Zob. rodzaje treści kształcenia za: W. Kojs, Treści kształcenia - stare i nowe problemy, [w:] K. Denek, T.M. Zimny (red.), Oświata na wirażu. IV Tatrzańskie Seminarium Naukowe, Wydawnictwo Andrzej Wiśniewski, Kielce 1999, s. 103. 
re posiadają ogromny potencjał i zaplecze w tym względzie ${ }^{25}$. Warto w tym miejscu zwrócić uwagę na jeszcze jeden bardzo ważny wątek, który pojawił się w analizach wypowiedzi nauczycieli, ogromną rolę powinnościową szkoły w kształtowaniu postaw kulturowych dzieci, młodzieży.

Szkoła to jedyny być może czas, gdy dzieci będą miały okazję zobaczyć to, co naprawdę wartościowe (nauczycielka języka polskiego, gimnazjum).

Wielu z młodych ludzi, kończąc edukację na poziomie ponadgimnazjalnym, nie będzie miało już obowiązku przeczytania książki (poza podręcznikiem akademickim), pójścia do muzeum, teatru, operetki, dlatego staramy się jako szkoła wykształcić w młodzieży taką wewnętrzną potrzebę, imperatyw, którym kierowaliby się w dorosłym życiu (nauczycielka języka polskiego, liceum).

Edukacja szkolna, edukacja formalna dotyczy wszystkich dzieci. Jest czasochłonnym zobowiązaniem wszystkich osób w Polsce do 18. roku życia. Nie można zmarnować tego potencjału osobowościowego i czasowego. To w czasie szkolnym kształtują się nawyki, postawy, potrzeby, które ukierunkowują nasze dorosłe życie. Rodzice wspomagają szkołę w tym zadaniu. Dlatego też każdorazowo pisząc o szkole i jej kulturotwórczej roli, podkreślać należy z dużą stanowczością zobowiązania szkoły w zakresie organizowania uczniom możliwości bezpośredniego, regularnego, odbywającego się w ramach kształcenia szkolnego, kontaktu z muzeum, teatrem, galerią sztuki, centrum nauki i innymi placówkami kulturowymi w kraju i za granicą.

\section{Uczeń w edukacji muzealnej}

Jednym z ważnych obszarów problemowych, jaki pojawiał się w wypowiedziach nauczycieli, dotyczył ucznia i jego charakterystyki w kontakcie z edukacją muzealną. Ważne ustalenie badawcze w tym obszarze problemowym można sformułować następująco: postawa ucznia wobec edukacji muzealnej, wizyt w muzeach wynika w dużej mierze z postawy nauczyciela. Świetnie wyraziła to nauczycielka języka polskiego z liceum, która napisała:

Innym problemem mógł być entuzjazm i zaangażowanie uczniów, ale tutaj bardzo szybko przekonałam się, że wszystko zależy ode mnie i mojego nastawienia. Nauczyciel swoim zapałem i energią potrafi porwać uczniów do działania lub brakiem zapału i energii zniechęcić ich do działania. Ponadto stosując odpowiednią motywację, tzn. traktując zajęcia z edukacji kulturowej jako element zajęć dydaktycznych, ocenianych na bieżąco i z których ocena ma wpływ na ocenę końcową, co więcej, nie jest mniej lub bardziej ważna od oceny ze sprawdzianu czy zadania klasowego, zyskałam zaangażowanie uczniów.

${ }^{25}$ R. Pater, Edukacja muzealna w Niemczech..., s. 204. 
Oprócz powiązania postawy nauczyciela z postawą ucznia nauczycielka zwróciła uwagę na równie ważną i trudną kwestię w pracy z uczniem w muzeum. Zaangażowanie ucznia w wizytę w muzeum zależy w dużej mierze od tego, jaką wagę nada jej nauczyciel w ocenie pracy uczniowskiej, w ocenie szkolnej. Nie może być bowiem tak, jak opisała jedna z nauczycielek, że „wyjście do muzeum traktowane było jak »dzień wolny«, czyli pozbawiony konieczności myślenia, a wszelkie próby »zaciekawiania « spełzały zazwyczaj na niczym” (nauczycielka języka polskiego i informatyki). Uczeń musi wiedzieć, czuć, że wizyta w muzeum jest ważna dla nauczyciela, że treści kształcenia przekazywane w muzeum są równoważne z treściami czerpanymi z podręcznika, przekazywanymi na lekcji, że stanowią element oceny postępów szkolnych uczniów.

Nauczyciele opisują dwie sytuacje edukacyjne w pracy muzealnej z uczniem. Pierwsza to praca z całą klasą. Edukacja muzealna przedstawiana jest tutaj jako część procesu dydaktycznego realizowanego w klasie na zajęciach, np. przy wykorzystaniu zdigitalizowanych zasobów muzeów oraz jako element wycieczek szkolnych. Druga to propozycja z zakresu edukacji muzealnej kierowana przez nauczyciela do wybranych uczniów w klasie, w szkole. Każda z opisanych sytuacji ma swoją specyfikę dydaktyczną. Zdecydowanie łatwiej, sprawniej, ciekawiej, efektywniej pracuje się z osobami chętnymi, zainteresowanymi, osobami dobrowolnie odpowiadającymi na propozycje nauczyciela. Uczniami realizującymi niejednokrotnie materiał rozszerzony z zakresu języka polskiego, czy też przygotowującymi się do realizacji projektów, konkursów, olimpiad przedmiotowych. Już znacznie trudniej pracuje się z całym zespołem klasowym w ramach realizacji programu szkolnego, tego podstawowego, a nie rozszerzonego, dla zainteresowanych. O trudach tej pracy dosadnie wypowiedziała się jedna $\mathrm{z}$ badanych nauczycielek:

Barierę drugą stawiają sami uczniowie. Wyjście do kina, teatru, galerii, muzeum, wycieczka muszą się opłacać - to znaczy, że w grę nie wchodzą wyjścia i wyjazdy pozalekcyjne, a też nie każdy dzień szkolny pasuje, bo tylko takie, w których lekcji jest najwięcej i są najtrudniejsze. Moje godziny do dyspozycji wychowawcy, zwane dawniej godzinami wychowawczymi, przypominają batalię toczoną o to, kiedy, gdzie i komu co się opłaca. Zawsze mi się wydawało, że barierą nie do przekroczenia mogą być kwestie finansowe i te najprędzej bym zrozumiała, ale obserwując na przestrzeni lat młodzież, z którą pracuję, widzę, że wysokość nakładów wydatkowanych na kształcenie kulturowe nie ma żadnego znaczenia (nauczycielka języka polskiego).

Zarysowana kondycja psychospołeczna współczesnej młodzieży nie jest dobra. W innych miejscach tej samej wypowiedzi przeczytać możemy o lenistwie kulturalnym, krytykanctwie, o braku zainteresowania, o wirtualizacji świata. Współczesne pokolenie młodych ludzi nauczycielka nazywa „pokoleniem pochylonych”, czyli pokoleniem korzystającym z gier na telefonach komórkowych. Jest to jedna z nielicznych wypowiedzi tak negatywnie rysująca obraz współczesnej młodzieży. Częściej 
jednak przeczytać możemy o dobrowolnym udziale uczniów w różnego rodzaju konkursach, projektach, pozytywnym odzewie na propozycje nauczyciela wyjść, wyjazdów do muzeów, samodzielnej inicjatywie uczniów zobaczenia sztuki w muzeum czy galerii sztuki. Prawdopodobieństwo kształtowania takich postaw uczniowskich wzrasta, gdy o edukacji muzealnej pamięta nauczyciel już w wychowaniu przedszkolnym:

Ogromne zadanie stoi przed nauczycielami wychowania przedszkolnego. To oni mogą przyczynić się do tego, że 6-7-latek będzie zainteresowany wizytą w muzeum czy galerii, a 3-4-latek, przechodząc przez miejski rynek, wysłucha historii o herbie Katowic lub zainteresuje go hejnał. Może ich zaangażowanie oraz aktywność spowoduje, że maluchy, gdy dorosną, zechcą żyć i pracować w mieście, w którym się urodziły. Będą tworzyć jego kulturę i historię (nauczycielka wychowania przedszkolnego).

Warunkiem owocnej pracy z uczniami jest umiejętność słuchania, rozpoznawania tożsamości klasy, z jaką mamy pracować jako nauczyciele przedmiotowi czy wychowawcy.

Trzeba nauczyć się słuchać. Jedna klasa będzie uwielbiała wystawy malarstwa, druga pokocha teatr, jeszcze inna fotografię, a czasami trzeba zadania indywidualizować, zlecając każdemu uczniowi coś innego (nauczycielka języka polskiego, liceum).

Edukacja muzealna stwarza dogodne warunki dla „zobaczenia” ucznia przez nauczyciela w innej sytuacji, nie tylko z perspektywy „ławki szkolnej”. Potencjał klasy może ujawnić się w nowej sytuacji i w obliczu nietypowych wyzwań, stąd też duża rola edukatorów muzealnych w przedstawianiu takich propozycji zajęć z uczniami, które są wartościowe dydaktycznie, a rzadkie w sytuacji szkolnej, jak np. praca z dziełem (oryginałem), działania praktyczne na wystawie, spotkanie z ekspertem. Sporadycznie jednak w warunkach szkolnych mamy do czynienia z sytuacją, gdy nauczyciel sprowadza wystawę do szkoły, jak np. opisywane przez nauczyciela języka polskiego sprowadzenie wystaw z Muzeum Galicja w Krakowie, dwóch wystaw z Centropy, wystawy z Ambasady Izraela:

Ciekawa ekspozycja składająca się z dużych, trójwymiarowych fotografii przykuwała uwagę uczniów. Obserwowałem, jak na przerwach oglądali ją, komentowali między sobą, wymieniali się uwagami z innymi (nauczyciel języka polskiego).

Sprowadzeniu wystaw towarzyszyły, w opisach nauczyciela, inne wydarzenia edukacyjne, kulturowe, tj.: uroczyste wernisaże z udziałem całej społeczności szkolnej i władz lokalnych; warsztaty plastyczne, warsztaty artystyczne, których tematyka odnosiła się do wartości, jakie promowała wystawa; wykłady prowadzone przez pracowników muzeum. Działania te podejmowane były zarówno we współpracy z innymi nauczycielami w szkole, jak również z udziałem i wsparciem dyrektora domu kultury. 


\section{Zakończenie}

Na łamach „Muzealnictwa” w 2012 roku Renata Pater pisała o potrzebie opracowania standardów pośredniczenia i edukacji muzealnej dla polskiego muzealnictwa, które to standardy pozwoliłyby na sensowne i docelowe działanie na linii muzeum i edukacja formalna (szkoła) oraz muzeum i przestrzeń edukacji otwartej (zróżnicowana publiczność i różnorodne instytucje) ${ }^{26}$. Treści zaprezentowanego artykułu przybliżają problematykę edukacji muzealnej z perspektywy dydaktycznej. Stanowią pewne uzupełnienie dla badań z zakresu edukacji muzealnej podejmowanych przez środowiska muzealników, edukatorów muzealnych, a tylko takie interdyscyplinarne spojrzenie badawcze przybliża nas do systemowych rozwiązań, w tym tych wiążących edukację szkolną z pozaszkolną.

\section{Bibliografia}

Allard M., Boucher S., Éduquer au musée. Un modele théorique de pédagogie muséale, Hurtubise HMH Ltée, Montréal 1998.

Allard M., Boucher S., Le musée et lécole, Hurtubise HMH Ltée, Montréal 1991.

Cabała A., Rodek V., W poszukiwaniu modeli edukacji kulturowej. Aktywność nauczycieli $i$ jej uwarunkowania w przestrzeni edukacji formalnej, Regionalny Instytut Kultury w Katowicach, Katowice 2017.

Czetwertyńska G., Szkoła i muzeum - spotkanie w pół drogi, [w:] M. Szeląg (red.), Edukacja muzealna w Polsce. Sytuacja, kontekst, perspektywy rozwoju. Raport o stanie edukacji muzealnej w Polsce, Narodowy Instytut Muzealnictwa i Ochrony Zbiorów, Muzeum Pałac w Wilanowie, Warszawa 2012.

Folga-Januszewska D., Muzeum: fenomeny i problemy, Universitas, Warszawa 2015.

Gałuszek O., Po co szkole muzeum, po co muzeum szkoła? O edukacji muzealnej z perspektywy prowadzacego zajęcia nauczyciela, [w:] M. Szeląg (red.), Edukacja muzealna $w$ Polsce. Sytuacja, kontekst, perspektywy rozwoju. Raport o stanie edukacji muzealnej w Polsce, Narodowy Instytut Muzealnictwa i Ochrony Zbiorów, Muzeum Pałac w Wilanowie, Warszawa 2012.

Gołaszewski T., Dziecko w muzeum, Nasza Księgarnia, Warszawa 1967.

Helling I.K., Metoda badań biograficznych, [w:] G. Włodarek, M. Ziółkowski (red.), Metoda biograficzna w socjologii, PWN, Warszawa-Poznań 1990.

Karwasz G., Kruk J., Idee i realizacje dydaktyki interaktywnej - wystawy, muzea i centra nauki, Wydawnictwo Naukowe Uniwersytetu Mikołaja Kopernika, Toruń 2012.

\footnotetext{
${ }^{26}$ R. Pater, W poszukiwaniu standardów edukacji muzealnej, „Muzealnictwo”, nr 3/2012, s. 135.
} 
Kojs W., Działanie jako kategoria dydaktyczna, Uniwersytet Śląski w Katowicach, Katowice 1994.

Kojs W., Treści kształcenia - stare i nowe problemy, [w:] K. Denek, T.M. Zimny (red.), Oświata na wirażu. IV Tatrzańskie Seminarium Naukowe, Wydawnictwo Andrzej Wiśniewski, Kielce 1999.

Kosińska M., Edukacja kulturowa [hasło], http://cpe.poznan.pl/dictionary/edukacja -kulturowa/ (dostęp: 2.10.2018).

Lalak D., Życie jako biografia. Podejście biograficzne w perspektywie pedagogicznej, Wydawnictwo Żak, Warszawa 2010.

Pater R., Edukacja muzealna w Niemczech, [w:] M. Szeląg (red.), Edukacja muzealna w Polsce. Sytuacja, kontekst, perspektywy rozwoju. Raport o stanie edukacji muzealnej w Polsce, Narodowy Instytut Muzealnictwa i Ochrony Zbiorów, Muzeum Pałac w Wilanowie, Warszawa 2012.

Pater R., W poszukiwaniu standardów edukacji muzealnej, „Muzealnictwo”, nr 3/2012. Raport Strategie Rozwoju Muzealnictwa. Założenia programowe, Narodowy Instytut Muzealnictwa i Ochrony Zbiorów, Warszawa 2012.

Szeląg M., Edukacja głupcze! Zadania muzeum na początku XXI wieku, [w:] Muzeum XXI wieku - teoria i praxis, Muzeum Początków Państwa Polskiego, Gniezno 2010.

Szeląg M., Edukacja muzealna i muzea w opiniach uczestników seminariów z cyklu „Raport o stanie edukacji muzealnej w Polsce. Suplement”, [w:] M. Szeląg (red.), Raport o stanie edukacji muzealnej. Suplement. Część 1, Universitas, Kraków 2014.

\section{Museum education in school practice - didactic challenges}

Abstract: This article discusses didactic reflection in relation to museum education. 27 teachers were sampled through recommendation-based selection and the method of thematic autobiography was used. The analysis concerned some fragments of teachers' autobiographies which were directly related to their professional work and the implementation of museum education in the school system. Two thematic fields are described. The first comprises teachers' comments on the interrelations of museum education and the implementation of the core curriculum of general education. The second field concerns the learner as the main recipient and direct participant of museum education.

Keywords: museum education, formal education, teacher, learner, core curriculum of general education

\footnotetext{
About the author: Agata Cabała - Ph.D in Humanities in the field of pedagogy. A senior lecturer in the Department of General Didactics and Pedeutology at the Faculty of Pedagogy and Psychology of the University of Silesia in Katowice. The faculty coordinator for collaboration with the Silesian Museum (Muzeum Śląskie) in Katowice and the Regional Institute of Culture (Regionalny Instytut Kultury) in Katowice. Research interests: system solutions for combining school and non-school education.
} 


\title{
Dobro dziecka w perspektywie sędziów rodzinnych i służb społecznych - kontekst wsparcia rodziny naturalnej w odzyskiwaniu opieki nad dzieckiem
}

DOI: 10.25312/2083-2923.15/2019_01ma

\begin{abstract}
Streszczenie: Decyzja o umieszczeniu dziecka poza rodziną jest trudna nie tylko dla przedstawicieli instytucji, które są zaangażowane w proces pomocy rodzinie i mają poczucie niepowodzenia swoich działań. Decyzja ta przesądza o przyszłości dziecka, o trwałości więzi łączących go z rodzicami biologicznymi oraz rodzeństwem. Także decyzja o powrocie dziecka do rodziny jest zwykle trudna, często też obarczona ryzykiem niepowodzenia, choć trzeba zaznaczyć, że reintegracja i odzyskanie opieki nad dzieckiem przez rodziców biologicznych powinna być celem działań podejmowanych wobec rodziny przez służby społeczne i jej przedstawicieli, o ile to tylko możliwe. Celem publikacji jest naświetlenie trudności, jakie mogą się pojawić w kontekście wsparcia rodziny naturalnej w odzyskiwaniu opieki nad dzieckiem. Aby je zilustrować, przedstawiono wyniki badań własnych autorki, w ramach których dokonano analizy pola semantycznego pojęcia „dobro dziecka”, w tym także analizy jego opozycji w odniesieniu do następujących środowisk zawodowych: sędziów rodzinnych, kuratorów zawodowych, pracowników socjalnych, asystentów rodziny, przedstawicieli dwóch typów organizacji społecznych sprofilowanych oraz animacyjnych.
\end{abstract}

Słowa kluczowe: dobro dziecka, dziecko, rodzina, sąd rodziny, służby społeczne, praca $\mathrm{z}$ rodziną, praca socjalna

* Magdalena Arczewska - doktor habilitowany nauk humanistycznych, jest socjolożką i prawniczką, pracuje jako adiunkt w Instytucie Stosowanych Nauk Społecznych Uniwersytetu Warszawskiego. Jest trenerką, badaczką i ewaluatorką z kilkunastoletnim doświadczeniem w pracy w Polsce i za granicą. Specjalizuje się w badaniach dotyczących polityki społecznej oraz współpracy administracji publicznej z organizacjami pozarządowymi na szczeblu rządowym i samorządowym. Jest członkinią Zarządu Stowarzyszenia Sędziów Rodzinnych w Polsce. 


\section{Wprowadzenie}

Sąd rodzinny jest ostatnim ogniwem w łańcuchu instytucji i podmiotów biorących udział w podjęciu decyzji dotyczących losów dziecka. Ma to szczególne znaczenie w odniesieniu do rodzin dotkniętych problemem niewydolności opiekuńczo-wychowawczej, w wyniku której dzieci umieszczane są poza rodziną. Decyzja o umieszczeniu dziecka poza rodziną jest trudna nie tylko dla przedstawicieli instytucji, które są zaangażowane w proces pomocy i mają poczucie niepowodzenia swoich działań. Konsekwencje działań instytucjonalnych dotyczą przede wszystkim przyszłości dziecka i wpływają na utrzymanie więzi łączących go z rodzicami biologicznymi oraz rodzeństwem. Także potencjalna reintegracja dziecka $z$ rodziną jest często obarczona ryzykiem niepowodzenia, choć trzeba zaznaczyć, że odzyskanie opieki nad dzieckiem przez rodziców biologicznych powinno być celem działań podejmowanych wobec rodziny przez służby społeczne i jej przedstawicieli, o ile to tylko możliwe.

Celem publikacji jest naświetlenie trudności, jakie mogą się pojawić w kontekście wsparcia rodziny naturalnej w odzyskiwaniu opieki nad dzieckiem. Aby je zilustrować, przedstawiono wyniki badań własnych autorki, w ramach których dokonano analizy pola semantycznego pojęcia „dobro dziecka”, w tym także analizy jego opozycji w odniesieniu do następujących środowisk zawodowych: sędziów rodzinnych, kuratorów zawodowych, pracowników socjalnych, asystentów rodziny, przedstawicieli dwóch typów organizacji społecznych - sprofilowanych oraz animacyjnych ${ }^{1}$. Materiał empiryczny zgromadzony przez autorkę w toku badań to rezultat przeprowadzenia 81 wywiadów pogłębionych zrealizowanych w okresie wrzesień-listopad 2015 roku, poszukiwania 173 aktów prawnych oraz analizy 208 pozycji z zakresu naukowej literatury przedmiotu. Zebrany materiał empiryczny opracowano według zasad metodologii jakościowej, wykorzystując metodę opisowo-ilustracyjną oraz metodę analizy pola semantycznego.

\section{Dobro dziecka jako pojęcie i kategoria prawna}

Dobro dziecka jest podstawowym zagadnieniem prawa rodzinnego, a jego ochrona stanowi jedną z kluczowych zasad systemu prawa. Choć pojęcie „dobro dziecka” nie jest definiowane na gruncie ustawowym, to w literaturze przedmiotu można odnaleźć próby jego dookreślenia. Warto w tym miejscu odwołać się do definicji sformułowanej przez Wandę Stojanowską, w której termin „dobro dziecka” w rozumieniu prawa rodzinnego oznacza kompleks wartości o charakterze niematerialnym i materialnym niezbędnych do zapewnienia prawidłowego rozwoju fizycznego i duchowego dziecka

${ }^{1} \mathrm{~W}$ publikacji wykorzystano ilustracyjną część materiału, który stanowi podstawę pracy autorki Dobro dziecka w perspektywie przedstawicieli wybranych środowisk zawodowych, Dom Wydawniczy Nomos, Kraków 2017. 
oraz do należytego przygotowania go do pracy odpowiednio do jego uzdolnień. Wartości te są zdeterminowane przez wiele różnorodnych czynników, na które wpływ ma aktualna sytuacja dziecka². Alicja Czerederecka wskazuje natomiast, że dobro dziecka wiąże się z idealnym modelem, który zakłada zaspokojenie potrzeby miłości, rozsądnie rozumianych oczekiwań, umożliwienie realizacji uzdolnień, a także samodzielnego i twórczego działania oraz kształtowania charakteru w duchu ideałów ${ }^{3}$. W opinii Henryka Haaka ,jest to model zorientowany nie tylko na aktualną sytuację dziecka, ale także zwrócony ku jego przyszłości i raczej owa dalsza perspektywa ideału dojrzałego człowieka zyskuje preferencje $\mathrm{w}$ razie kolizji z wartościami rozpatrywanymi jedynie z punktu widzenia aktualnych potrzeb dziecka" ${ }^{4}$.

Do lat 20. XX wieku o tym, jakie prawa mają dzieci, decydowały poszczególne państwa. Formalizacja praw dziecka stała się możliwa dzięki postępowi legislacyjnemu dotyczącemu dzieci, lepszemu poznaniu procesu rozwoju dziecka, umacnianiu się podejścia humanistycznego do jednostki i postępowi w dziedzinie implementacji praw człowieka 5 . Ewolucja prawa w kierunku ochrony życia i praw dziecka postępowała bardzo powoli. Prekursorem zakazu stosowania kar cielesnych była Szwecja, gdzie dopiero od 1979 roku zaczęło obowiązywać prawo zakazujące fizycznego karania dzieci. Ustawowy zakaz bicia stopniowo wprowadziły między innymi: Austria, Dania, Norwegia, Cypr i Włochy. Pełna świadomość społeczna praw dziecka jest dorobkiem ostatnich kilku dekad. Sytuacja ta jest wynikiem wprowadzania do krajowych porządków prawnych przepisów mających na celu ochronę interesów dziecka, tworzenia stosownych regulacji na poziomie międzynarodowym i wreszcie uchwalenia i ratyfikacji w wielu krajach Konwencji o prawach dziecka ${ }^{6}$.

Konwencja traktuje dobro dziecka jako wartość nadrzędną wymagającą preferencyjnego traktowania w zestawieniu $\mathrm{z}$ innymi interesami osób fizycznych i prawnych. Nie zawiera porównania lub odniesienia do interesu państwa lub interesu społecznego, co świadczy o bezwzględnej preferencji w tym zakresie ${ }^{7}$. Choć w treści Konwencji nie sformułowano definicji pojęcia „dobro dziecka”, to odwołując się do Preambuły tego aktu, można wskazać na elementy, które na dobro to się składają. Otóż „dziecko ma prawo do szczególnej troski i pomocy, dla pełnego i harmonijnego rozwoju swojej

${ }^{2}$ Por. W. Stojanowska, Rozwód a dobro dziecka, Wydawnictwo Prawnicze, Warszawa 1970.

3 A. Czerederecka, Rozwód a rywalizacja o opiekę nad dziećmi, Wydawnictwo LexisNexis, Warszawa 2010, s. 40.

${ }^{4}$ H. Haak, Władza rodzicielska. Kodeks rodzinny i opiekuńczy. Komentarz, Towarzystwo Naukowe Organizacji i Kierownictwa, Toruń 1995, s. 49.

${ }^{5}$ J. Błeszyński, A. Rodkiewicz-Ryżek, Ochrona praw dziecka wświetle standardów polskich i międzynarodowych, „Pedagogia Christiana”, nr 2(30)/2012, s. 96-97.

${ }^{6}$ Od Deklaracji genewskiej do Konwencji o prawach dziecka. Rys historyczny, opracowanie dostępne na stronie Biura Rzecznika Praw Dziecka: https://brpd.gov.pl/sites/default/files/rpd stare/ uploadfiles/04str 20 lat kopd historia.pdf (dostęp: 14.09.2018).

7 T. Smyczyński, Prawo rodzinne i opiekuńcze. System prawa prywatnego, Wydawnictwo Naukowe PWN, Warszawa 2005, s. 43. 
osobowości powinno wychowywać się w środowisku rodzinnym, w atmosferze szczęścia, miłości i rozumienia, powinno być w pełni przygotowane do życia w społeczeństwie jako indywidualnie ukształtowana jednostka, a z uwagi na swoją niedojrzałość fizyczną oraz umysłową wymaga szczególnej opieki i troski, w tym właściwej ochrony prawnej, zarówno przed, jak i po urodzeniu".

Prawo międzynarodowe w szczególny sposób uregulowało prawa dzieci oraz objęło ochroną zwłaszcza ich zdrowie, edukację, pracę i prawo do posiadania rodziny. Wszystkie te zagadnienia stały się przedmiotem regulacji specyficznych dziedzin prawa międzynarodowego, pozostając jednocześnie elementem szeroko rozumianej międzynarodowej ochrony praw człowieka. Prawo międzynarodowe określa minimalny katalog praw i wolności dziecka, który nie może być uszczuplony przez prawo krajowe. Ponadto prawo międzynarodowe w zakresie ochrony praw dziecka tworzy mechanizmy kontrolne zmierzające do zapewnienia odpowiedniego poziomu ochrony praw i wolności dzieci na poziomie krajowym ${ }^{8}$.

W polskim prawie ochrona dobra dziecka stanowi podstawową zasadę prawa rodzinnego, wynikającą z Konstytucji i skonkretyzowaną w Kodeksie rodzinnym i opiekuńczym. Znaczenie mają także przepisy Kodeksu postępowania cywilnego, Regulaminu urzędowania sądów powszechnych, ustawy o wspieraniu rodziny i systemie pieczy zastępczej oraz ustawy o przeciwdziałaniu przemocy w rodzinie. Otóż „dobro dziecka” w perspektywie realizacji obowiązków rodziców wobec dzieci oznacza konieczność zapewnienia dziecku warunków rozwoju osobowego i egzystencji materialnej. Przy ocenie „dobra dziecka” nie można pomijać też obiektywnych uwarunkowań, takich jak: wiek dziecka, jego płeć, cechy charakterologiczne rodziców, wzajemny stosunek rodziców do siebie, do dziecka oraz do krewnych rodzica. Nie bez znaczenia są również subiektywne kryteria, takie jak: wrażliwość dziecka, wzajemne relacje oraz więzi rodziców i dzieci, poczucie bezpieczeństwa dziecka. Należy zatem uznać, że elementy te tworzą model „dobra dziecka”.

\section{Wnioski z badań własnych}

Przedstawiciele wszystkich badanych środowisk zawodowych w spójny sposób definiowali pojęcie „dobro dziecka”. Jest to zatem całokształt działań mających na celu zapewnienie dziecku nie tylko podstawowych potrzeb materialnych, ale także stworzenie mu warunków dla harmonijnego rozwoju we wszystkich sferach, w tym psychicznej i emocjonalnej. Elementem dobra dziecka jest także zapewnienie mu poczucia bezpieczeństwa i stabilizacji. Zdaniem rozmówców biorących udział w badaniach, nie bez przyczyny pojęcie „dobro dziecka” nie zostało wprost zdefiniowane

8 A. Prusinowska-Marek, Zapewnienie bezpieczeństwa i pomoc dziecku w sytuacji kryzysowej. Praktyczny przewodnik dla osób pracujących z dzieckiem i rodziną, Mazowieckie Centrum Polityki Społecznej, Warszawa 2015, s. 13. 
w przepisach prawnych, a jego interpretacja zależy od danego stanu faktycznego i sytuacji, w jakiej znajduje się konkretne dziecko. Można zatem sformułować pogląd, iż nie ma jednej, uniwersalnej definicji pojęcia „dobro dziecka”, ponieważ wiek i indywidualne potrzeby dziecka determinują jego dobro. Warto podkreślić, że w wypowiedziach sędziów rodzinnych dotyczących definiowania pojęcia „dobro dziecka” pojawił się także wątek wychowania w kontekście podejmowania ról społecznych w dorosłym życiu.

W sieci opozycji pojęcia „dobro dziecka” wyodrębniono kilka kategorii wyrażeń z uwagi na ich specyfikę oraz częstość występowania. Przedstawiona niżej analiza prezentuje wyniki odnoszące się do zestawienia sieci opozycji pojęcia „dobro dziecka” z uwzględnieniem wyodrębnionych kategorii (grup zagadnień) dla wszystkich grup respondentów. Wskazano w niej przykłady obrazujące podobieństwa i różnice występujące w zakresie zestawienia sieci opozycji i wyodrębnionych w jej ramach kategorii pomiędzy poszczególnymi grupami respondentów. Utworzone kategorie stanowią wynik analizy wyrażeń, które pojawiły się w zebranym materiale badawczym. Materiał ten potwierdził wiedzę utrwaloną w literaturze przedmiotu, a zagadnienia, które stanowią kategorie analityczne, wskazywane są w doktrynie i orzecznictwie jako trwałe przeszkody uniemożliwiające wykonywanie władzy rodzicielskiej oraz czynniki, których występowanie w rodzinie zwiększa ryzyko zaistnienia w niej zjawiska krzywdzenia dziecka.

Tabela 1. Zestawienie sieci opozycji pojęcia „dobro dziecka” z uwzględnieniem wyodrębnionych kategorii dla poszczególnych grup respondentów ( $\mathrm{S}$ - sędziowie rodzinni, K - kuratorzy rodzinni, PS - pracownicy socjalni, A - asystenci rodziny, OP - przedstawiciele organizacji sprofilowanych, $\mathrm{OA}$ - przedstawiciele organizacji animacyjnych)

\begin{tabular}{|c|c|c|c|c|c|c|c|c|c|}
\hline Kategoria & & S & $\mathrm{K}$ & PS & A & $\mathrm{OP}$ & $\mathrm{OA}$ & Ogółem LB & Ogółem \% \\
\hline \multirow[t]{2}{*}{ Niezaspokojenie potrzeb dziecka } & LB & 51 & 37 & 151 & 57 & 22 & 15 & 333 & \\
\hline & $\%$ & 15 & 11 & 45 & 17 & 7 & 4 & & 42 \\
\hline \multirow[t]{2}{*}{ Przemoc } & LB & 22 & 21 & 26 & 20 & 39 & 5 & 133 & \\
\hline & $\%$ & 16 & 16 & 20 & 15 & 29 & 4 & & 17 \\
\hline \multirow[t]{2}{*}{ Uzależnienie rodzica/opiekuna } & LB & 5 & 21 & 51 & 34 & 8 & 5 & 124 & \\
\hline & $\%$ & 4 & 17 & 41 & 27 & 7 & 4 & & 16 \\
\hline \multirow[t]{2}{*}{ Brak kontaktu z osobą bliską } & LB & 33 & 12 & 8 & 8 & 7 & 1 & 69 & \\
\hline & $\%$ & 48 & 17 & 11 & 11 & 10 & 1 & & 9 \\
\hline \multirow[t]{2}{*}{ Nieodpowiednie traktowanie } & LB & 10 & 22 & 10 & 13 & 10 & 0 & 65 & \\
\hline & $\%$ & 15 & 34 & 15 & 20 & 15 & 0 & & 8 \\
\hline \multirow[t]{2}{*}{ Brak stabilizacji } & LB & 13 & 4 & 4 & 2 & 6 & 2 & 31 & \\
\hline & $\%$ & 42 & 13 & 13 & 6 & 20 & 6 & & 4 \\
\hline
\end{tabular}




\begin{tabular}{|l|r|r|r|r|r|r|r|r|r|}
\hline \multicolumn{1}{|c|}{ Kategoria } & & \multicolumn{1}{c|}{ S } & \multicolumn{1}{c|}{ K } & PS & A & OP & OA & Ogółem LB & Ogółem \% \\
\hline Procedura prawna & LB & 13 & 1 & 2 & 0 & 1 & 0 & $\mathbf{1 7}$ & \\
\cline { 2 - 10 } & $\%$ & 76 & 6 & 12 & 0 & 6 & 0 & & $\mathbf{2}$ \\
\hline Kwestionowanie orzeczenia sądu & LB & 0 & 3 & 12 & 0 & 2 & 0 & $\mathbf{1 7}$ & $\mathbf{2}$ \\
\cline { 2 - 10 } & $\%$ & 0 & 18 & 71 & 0 & 12 & 0 & & $\mathbf{1 0 0}$ \\
\hline Ogółem & & 147 & 121 & 264 & 134 & 95 & 28 & $\mathbf{7 8 9}$ & $\mathbf{1 0 0}$ \\
\hline
\end{tabular}

Źródło: opracowanie własne.

\section{Niezaspokojenie potrzeb dziecka}

Kategoria „niezaspokojenie potrzeb dziecka” była najliczniej reprezentowaną kategorią wyrażeń w sieci opozycji. Ma ona łącznie aż $42 \%$ wskazań. Niezaspokojenie potrzeb dziecka stanowi zatem sytuację, z którą mają do czynienia przedstawiciele wszystkich badanych środowisk zawodowych. Jak wynika $\mathrm{z}$ tabeli zawierającej dane porównawcze dla poszczególnych grup respondentów, najliczniej kategoria ta była prezentowana w wypowiedziach pracowników socjalnych (45\%). W grupie asystentów stanowiła ona $17 \%$ wskazań, w grupie sędziów rodzinnych 15\%, a w grupie kuratorów $11 \%$. Najmniej licznie pojawiała się w wypowiedziach przedstawicieli obu typów organizacji społecznych - u przedstawicieli organizacji sprofilowanych stanowiła $7 \%$ wskazań, a u przedstawicieli organizacji animacyjnych $-4 \%$. Zebrane wyrażenia nie różnicują badanych środowisk zawodowych w tej kategorii. Należy podkreślić jednak, że chociaż pracownicy socjalni deklarowali, iż narzędzia, jakimi dysponują (w szczególności rodzinny wywiad środowiskowy oraz świadczenie pracy socjalnej w środowisku), nie dają im realnych możliwości wywierania wpływu na klientów, to jednak analiza pola semantycznego wskazuje na to, że dostarczają one szerokiej wiedzy na temat sytuacji dziecka w rodzinie, właśnie w kontekście niezaspokojenia jego potrzeb. Jeśli chodzi o wyrażenia zebrane w tej kategorii, to przedstawiciele wszystkich środowisk wskazywali na to, że opozycją „dobra dziecka” jest niezaspokajanie jego potrzeb zarówno fizjologicznych, jak i psychicznych, np.: „brak jedzenia, brak zasad higieny, zaniedbywanie dzieci, śmierdząca dziewczynka, brak uwagi dla dziecka, brak czasu dla dzieci".

Wskazywano także na pojęcia odnoszące się do niezaspokojenia potrzeb emocjonalnych. Respondenci wskazywali tu na różne sytuacje, chociażby na brak zainteresowania dzieckiem przez rodziców, np.: „niewidzenie dziecka, niezajmowanie się chłopcem przez matkę”; „pozostawianie dzieci samych, brak opieki matki, brak chęci do wychowywania dziecka przez matkę", czy też zaprzestanie odwiedzania dziecka umieszczonego w placówce opiekuńczo-wychowawczej przez rodzica czy rodziców lub oszukiwanie dziecka przez rodzica lub rodziców, że podejmują oni działania mające na celu powrót dziecka do rodziny: „karmienie Zosi przez matkę opowieścią, że wróci”; „odczuwanie przez córkę bycia zradzaną przez matkę”. 
Wyodrębnione w tej kategorii wyrażenia wskazują także na opozycję odnoszącą się do niezabezpieczania potrzeb zdrowotnych, np.: „wszawica dzieci, nieszczepienie dzieci, grzybica dzieci”; „chorowanie na świerzb przez dzieci”; „medyczne zaniedbanie dzieci”. Odnotowane pojęcia wskazują także na problem niezabezpieczenia potrzeb związanych z zamieszkiwaniem w odpowiednich warunkach, np.: „brak łazienki, złe warunki mieszkaniowe, straszne warunki, strasznie zimno".

Wreszcie w kategorii „niezaspokojenie potrzeb dziecka” licznie we wszystkich grupach badanych występowały wyrażenia wskazujące na niezaradność opiekuńczo-wychowawczą rodziców lub rodzica, która prowadzi do zaniedbywania potrzeb dziecka, np.: „niezaradność ojca, nieudolność ojca”; „niewydolność rodziców”; „nieogarnięcie matki”; „niewydolność wychowawcza matki”.

\section{Przemoc}

„Przemoc” jako kategoria wyodrębniona w zestawieniu sieci opozycji pojęcia „dobro dziecka” dla wszystkich grup respondentów otrzymała $17 \%$ wskazań. W kategorii tej frekwencje wyrażeń w poszczególnych środowiskach zawodowych rozkładały się dość równomiernie. Niemniej jednak najwięcej, bo blisko 1/3 (29\%) opozycji zaliczonych do tej kategorii przypisano przedstawicielom sprofilowanych organizacji społecznych. Drugą co do liczebności grupą odwołującą się do tej kategorii byli pracownicy socjalni - tu otrzymano $20 \%$ wskazań. W badanych środowiskach asystentów rodziny, kuratorów rodzinnych oraz sędziów otrzymano zbliżone wyniki odpowiednio: 15\%, 16\% oraz 16\% w odniesieniu do wszystkich grup respondentów. Najmniej, bo jedynie $4 \%$ wskazań dla tej kategorii otrzymano w grupie przedstawicieli organizacji animacyjnych.

Fakt, że przedstawiciele sprofilowanych organizacji społecznych tak często wskazują na pojęcia dotyczące przemocy, wynika z tego, że organizacje, w których działają w ramach swojej działalności statutowej, zajmują się wspieraniem dziecka i rodziny w sytuacji kryzysowej oraz pomocą dla dzieci umieszczonych poza rodziną. Ich działania często dotyczą właśnie przeciwdziałania skutkom przemocy, których doświadczyły podopieczni - dzieci, poprzez świadczoną pomoc terapeutyczną czy wsparcie psychologiczne. Sytuacje związane z przemocą, jakiej doświadczają dzieci, tworzą społeczny zasób wiedzy tej grupy badanych. Przedstawiciele sprofilowanych organizacji społecznych wskazywali na różnorodne przykłady sytuacji przemocowych, odnoszących się do przemocy psychicznej, fizycznej oraz seksualnej, np.: „drastyczne maltretowanie fizyczne”; „wykorzystywanie”; „nadużycie seksualne”. Zróżnicowanie w stosowanych przykładach widać także w grupie pracowników socjalnych: „bicie dziecka przez matkę”; „konflikty”; „wymierzanie kar fizycznych, podduszanie dzieci przez matkę”, oraz kuratorów rodzinnych: „dotykanie chłopca w miejsca intymne”; „konflikty”; „krzyki”; „przemoc psychiczna w stosunku do dzieci”. Z kolei w wypowiedziach sędziów rodzinnych dotyczących kategorii „przemoc” dominują wyraże- 
nia dotyczące molestowania i wykorzystywania seksualnego, np. „gwałcenie dziecka, molestowanie dziecka”. W tym środowisku zawodowym pojawił się także problem przyzwolenia na stosowanie przemocy przez drugiego rodzica czy opiekuna - tolerowanie molestowania seksualnego czy bicia, np. „godzenie się przez matkę (na molestowanie)". Z kolei w wypowiedziach badanych asystentów rodziny nie znalazły się wyrażenia nawiązujące do stosowania przemocy seksualnej. Badani z tej grupy odwoływali się do stosowania przemocy fizycznej, np. „bicie dzieci przez wujka”, oraz przemocy psychicznej, której towarzyszą „kłótnie”; „awantury” czy „krzyki”. Wreszcie, choć w grupie badanych przedstawicieli animacyjnych organizacji społecznych wyrażenia związane z przemocą jako opozycją „dobra dziecka” miały najniższą frekwencję, to były one drastyczne, np. „gwałcenie dziecka, permanentne zagrożenie życia dziecka”.

\section{Uzależnienie rodzica/opiekuna}

„Uzależnienie rodzica/opiekuna” jako kategoria wyodrębniona w zestawieniu sieci opozycji pojęcia „dobro dziecka” dla wszystkich badanych środowisk zawodowych otrzymała 16\% wskazań. Jest to więc trzecia pod względem frekwencji kategoria w sieci opozycji. Jak wynika z tabeli 1, zawierającej dane porównawcze dla poszczególnych grup respondentów, w kategorii „uzależnienie rodzica/opiekuna” aż 41\% wskazań pochodzi od pracowników socjalnych, a dalsze $27 \%$ od asystentów rodziny. Łącznie stanowi to blisko $70 \%$ wszystkich wskazań. Znacznie mniej, bo $17 \%$ pojęć zaliczonych do tej kategorii wyrażonych zostało przez kuratorów, 7\% przez przedstawicieli organizacji sprofilowanych, a po $4 \%$ przez sędziów rodzinnych oraz przedstawicieli organizacji animacyjnych. Trzeba zauważyć, że uzależnienie jako problem występujący w rodzinie, który rzutuje na sytuację dziecka, jest ujawniany przede wszystkim przez pracowników służb pomocy i integracji społecznej - pracowników socjalnych i asystentów rodziny, co wynika ze specyfiki ich pracy z podopiecznymi (głównie w środowisku rodziny) i prowadzoną diagnozą (ocena sytuacji życiowej osoby/rodziny w kontrakcie socjalnym; wskazanie przyczyny wystąpienia z wnioskiem o udzielenie pomocy albo udzielenia pomocy $\mathrm{z}$ urzędu w rodzinnym wywiadzie środowiskowym; opracowanie planu pracy $\mathrm{z}$ rodziną).

Kwestia uzależnienia i walki z nałogiem (najczęściej alkoholowym) pojawiała się w wypowiedziach wszystkich grup respondentów - przedstawicieli badanych środowisk zawodowych, np.: „alkoholizm rodziców”; „pijaństwo” (sędziowie rodzinni); „alkoholizm ojca”; „picie matki” (kuratorzy rodzinni); „pijący tata”; „obecność alkoholu w domu”; „upijanie się przez rodziców do nieprzytomności”; „karmienie dziecka piersią przez pijącą matkę” (pracownicy socjalni); „pijana ciężarna matka leżąca w rowie”; „pijaństwo rodziców” (asystenci rodziny); „nietrzeźwiejąca matka” (przedstawiciele organizacji sprofilowanych); „problem alkoholowy w rodzinie” (przedstawiciele organizacji animacyjnych). Z wypowiedzi respondentów wynikało jednak, że coraz 
częściej mają oni do czynienia z innymi formami uzależnienia - od narkotyków, leków, Internetu, gier hazardowych oraz seksu.

\section{Brak kontaktu z osobą bliską}

Brak kontaktu dziecka z osobą bliską zwykle dotyczy braku kontaktu dziecka $\mathrm{z}$ jednym $\mathrm{z}$ rodziców, utrudnionym kontaktem $\mathrm{z}$ rodzicem lub jego bliskimi - babcią czy dziadkiem w związku z konfliktem pomiędzy byłymi partnerami. Brak kontaktu z osobą bliską jako kategoria wyodrębniona w zestawieniu sieci opozycji pojęcia „dobro dziecka” dla wszystkich grup respondentów otrzymała 9\% wskazań. Natomiast z uwzględnieniem poszczególnych kategorii badanych w kategorii tej blisko połowa wskazań pochodzi od sędziów rodzinnych. Znacznie mniej, bo 17\% pojęć zaliczonych do tej kategorii wyrażonych zostało przez kuratorów, a po $11 \%$ przez pracowników socjalnych i asystentów rodziny oraz $10 \%$ przez przedstawicieli organizacji sprofilowanych. W tej kategorii tylko $1 \%$ wyrażeń stanowią pojęcia sformułowane przez przedstawicieli organizacji animacyjnych. Analiza ta wskazuje, że brak kontaktów dziecka $z$ rodzicem lub utrudnienie tego kontaktu stanowi istotną opozycję pojęcia „dobro dziecka” w wypowiedziach sędziów rodzinnych. Może to wskazywać na powszechność i wagę tego zjawiska w sprawach prowadzonych przez sędziów rodzinnych. Sędziowie wskazywali głównie na przykłady braku kontaktu dziecka z jednym z rodziców spowodowanego konfliktem pomiędzy rodzicami (często okołorozwodowym), np.: „brak możliwości odwiedzania dziecka”; „ograniczanie ojcu kontaktów przez matkę”; „oderwanie dziecka od ojca”. W wyniku istniejącego konfliktu jeden z rodziców może utrudniać drugiemu rodzicowi realizację kontaktów z dzieckiem. Formą utrudnienia może być na przykład stała obecność drugiego rodzica w trakcie spotkania rodzica realizującego kontakt z dzieckiem. Dochodzi też do sytuacji, w której rodzice wykorzystują dziecko w prowadzonym ze sobą sporze, wciągają je w konflikt i nastawiają wrogo wobec drugiego rodzica. W wyniku tego dziecko nie chce się spotykać z rodzicem, np. „brak chęci córki do spotykania się z ojcem”. W tej grupie pojawiły się też przykłady utrudniania kontaktów z rodziną dziecka ze strony jednego z rodziców przez drugiego rodzica, np. „zabranianie chłopcu chodzenia do dziadków przez matkę". Kolejnym typem wyróżnionych pojęć w wypowiedziach sędziów rodzinnych są pojęcia odnoszące się do sytuacji związanych z brakiem obecności jednego lub obojga rodziców. Sytuacje te wynikają z realizacji zamierzeń i planów rodzica lub rodziców godzących w dobro dziecka, np. pozostawienie dzieci związane z wyjazdem do nowo poznanego partnera czy partnerki, np. „nagły wyjazd matki do Niemiec".

Co interesujące, o ile brak kontaktu w wypowiedziach sędziów rodzinnych był przede wszystkim wynikiem konfliktu pomiędzy rodzicami lub dotyczył utrudniania kontaktów na tle tegoż konfliktu, to w tej kategorii w odniesieniu do kuratorów sądowych znalazły się pojęcia nawiązujące do sytuacji związanych z brakiem obecno- 
ści jednego lub obojga rodziców, jednak nieuwarunkowane konfliktem, a wynikające z postawy rodzica, np.: „odejście matki od dzieci”; „odpuszczenie kontaktów przez rodziców”; „nierobienie niczego, aby odzyskać dzieci”.

Z wypowiedzi pracowników socjalnych wynikało, że konflikt stanowi tło braku kontaktu dzieci z jednym z rodziców, co ilustrują następujące przykłady: „niechęć starszego syna do kontaktów z ojcem”; „brak kontaktu z ojcem przez wpływ matki i babci”; „odizolowanie dzieci”. Z kolei wypowiedzi asystentów wskazywały raczej na sytuacje związane z porzuceniem dzieci czy rodziny, np. „nieobecność ojca czy pozostawienie dzieci przez matkę”. W grupie przedstawicieli sprofilowanych organizacji społecznych występowały oba wskazane wyżej typy pojęć, np. „nieodwiedzanie dzieci przez matkę”; „uniemożliwianie kontaktów z ojcem”. W grupie przedstawicieli animacyjnych organizacji społecznych pojęcie związane z brakiem kontaktu z osobą bliską pojawiło się jedynie raz: „brak ojca”. Narracje badanych należących do wszystkich środowisk poza środowiskiem sędziowskim wskazywały, że brak kontaktu z osobą bliską jest elementem szerszego kontekstu, tłem, na którym prezentowana jest sytuacja dziecka.

\section{Nieodpowiednie traktowanie}

W ramach tej kategorii mieszczą się wyrażenia nie tylko takie, które wskazują na traktowanie dzieci przez rodziców w sposób nieadekwatny do ich wieku czy możliwości (postawa nadmiernie wymagająca oraz postawa nadmiernie ochraniająca), ale także odnoszące się do braku kształtowania przez rodziców u dzieci odpowiednich postaw i przekazywania im wymaganych społecznie wzorów zachowań. Wreszcie w tej kategorii zawarto także wyrażenia wskazujące na brak stosowania jakiegokolwiek stylu wychowawczego w rodzinie oraz na traktowanie dzieci przez rodziców w sposób nieodpowiedni do relacji rodzic-dziecko.

„Nieodpowiednie traktowanie” dziecka jako kategoria wyodrębniona w zestawieniu sieci opozycji pojęcia „dobro dziecka” dla wszystkich grup respondentów otrzymała 7\% wskazań. Najliczniej kategoria ta była prezentowana w wypowiedziach kuratorów rodzinnych (34\%). W grupie asystentów stanowiła ona $20 \%$ wskazań, a dla grup pracowników socjalnych, sędziów rodzinnych oraz przedstawicieli organizacji sprofilowanych po $15 \%$ wskazań. Nie była ona prezentowana w wypowiedziach przedstawicieli animacyjnych organizacji społecznych.

W wypowiedziach pracowników socjalnych pojawiły się wyrażenia wskazujące na traktowanie dzieci przez rodziców w sposób nieodpowiedni do relacji rodzicdziecko, np.: „obciążanie córki przez matkę mówieniem, że sobie nie radzi”; „przyprowadzanie dziewczynki na nierząd przez matkę". W wypowiedziach asystentów rodziny odnotowano wyrażenia wskazujące na występowanie u rodziców postawy nadmiernie ochraniającej i nadmiernie wymagającej, np.: „noszenie pampersa przez czteroletniego chłopca”; „oczekiwanie przez matkę opieki od kilkuletniego syna”; „przejmowanie roli matki przez dziewczynkę”. 
Z uwagi na najliczniej reprezentowaną kategorię „nieodpowiednie traktowanie” w wypowiedziach kuratorów odnotowano tu szerokie spectrum wyrażeń wskazujących zarówno na występowanie u rodziców postawy nadmiernie wymagającej, jak i nadmiernie ochraniającej, a także brak wychowania oraz traktowanie dzieci przez rodziców w sposób nieodpowiedni do tej relacji, np.: „traktowanie córki przez matkę jak koleżankę”; „nieprzekazywanie wzorców”; „przetrzymywanie syna w kojcu”; „narzucanie dzieciom specjalnej diety wymyślonej przez rodziców”; „spanie dziewczynki z panami w jednym łóżku”.

W badanym środowisku zawodowym sędziów rodzinnych pojawiały się wypowiedzi wskazujące na traktowanie dzieci przez rodziców w sposób nieodpowiedni do relacji rodzic-dziecko, np. traktowanie córki przez matkę jak koleżanki: „opowiadanie przez matkę córce, z którym facetem jest jej dobrze”; „opowiadanie przez matkę córce, z którym facetem jest jej źle”. Do tej kategorii zaliczono także sytuacje, w których jedno z rodziców instruowało dzieci, jak i co mają mówić w kontakcie z psychologiem czy pracownikiem socjalnym, np. „uczenie dziewczynki przez matkę, jak należy płakać, jak pójdą do pomocy społecznej”. Sędziowie odwoływali się do sytuacji, w których starsze dzieci przejmowały rolę opiekuńczą w stosunku do młodszego rodzeństwa, podczas gdy rodzice wycofywali się z tej roli np. w związku z uzależnieniem od alkoholu, problemami psychologicznymi, pogłębiającą się chorobą psychiatryczną czy zaangażowaniem się w związek z kolejnym partnerem, np. „wykonywanie zabiegów pielęgnacyjnych przez chłopca przy bratu”; „traktowanie Zosi jak opiekunki do małych dzieci”.

W grupie badanych przedstawicieli sprofilowanych organizacji społecznych pojawiły się wyrażenia wskazujące na odwoływanie się do postawy nadmiernie ochraniającej, np. „zmuszanie do zabiegów higienicznych”. W tej grupie wskazywano także na skrajne formy takiego traktowania objawiające się leczeniem dzieci na wyimaginowane choroby, np. „podawanie dziecku leków przeciwpadaczkowych”, w sytuacji gdy były one zdrowe.

\section{Brak stabilizacji}

Opozycją pojęcia „dobro dziecka” jest „brak stabilizacji” sytuacji życiowej dziecka, co wpływa na jego poczucie bezpieczeństwa i harmonijny rozwój. „Brak stabilizacji” może być skutkiem przedłużającej się procedury adopcyjnej, jednak w większości sytuacji wynika on z konfliktu pomiędzy rodzicami w zakresie uzgodnienia kwestii wychowawczych oraz ustalenia miejsca pobytu dziecka. Skutkiem braku porozumienia może być na przykład długotrwałe ukrywanie dziecka przez jednego z rodziców, nierealizowanie obowiązku szkolnego, ciągła zmiana miejsca pobytu. „Brak stabilizacji” jako kategoria wyodrębniona w zestawieniu sieci opozycji pojęcia „dobro dziecka” dla wszystkich grup respondentów otrzymał 4\% wskazań. W odniesieniu do poszczególnych grup badanych najwięcej wskazań dla kategorii „brak stabilizacji” odnoto- 
wano w badanym środowisku sędziów rodzinnych - było to $42 \%$. Znacznie mniej, bo $20 \%$ pojęć zaliczonych do tej kategorii wyrażonych zostało przez przedstawicieli sprofilowanych organizacji społecznych. Po $13 \%$ wypowiedzi przypisano pracownikom socjalnym oraz kuratorom, a po $6 \%$ asystentom rodziny i przedstawicielom organizacji animacyjnych. Podobnie jak w odniesieniu do kategorii „braku kontaktu z osobą bliską" może to wskazywać na wagę tego zjawiska w sprawach prowadzonych przez sędziów rodzinnych. Jak wynika z wypowiedzi sędziów rodzinnych, brakiem stabilizacji sytuacji życiowej dziecka jest np.: „wywożenie dziecka za granicę”; „ciągłe zmiany miejsca zamieszkania”; „zabieranie w kolejne miejsce”; „oddawanie w kolejne miejsce”; „wywożenie dziecka gdzieś”. Wpływa to na jego poczucie bezpieczeństwa i harmonijny rozwój. Najczęściej przyczyną tego stanu jest konflikt pomiędzy jego rodzicami, którzy walcząc ze sobą, składają kolejne pozwy i wysuwają niekończące się wzajemne oskarżenia. Taki sam schemat postępowania rodziców względem dziecka obrazują wypowiedzi przedstawicieli sprofilowanych organizacji społecznych, np. „kompletne utracenie poczucia bezpieczeństwa”; „podrzucanie dzieci w różne miejsca”; „poczucie tymczasowości”, oraz pracowników socjalnych: „przewożenie dziecka gdzieś”; „konflikt okołorozwodowy”.

Co ważne, wypowiedzi kuratorów zaliczone do tej kategorii ogniskują się wokół problemu nieuregulowanej sytuacji prawnej dzieci, która sprawia, że nie mogą one trafić do nowego środowiska rodzinnego, np.: „nieuregulowana sytuacja prawna dzieci”; „przetrzymywanie dzieci w placówkach przez wiele lat”; „brak szansy na adopcję”. W pojedynczych wypowiedziach asystentów rodziny oraz przedstawicieli animacyjnych organizacji społecznych pojawiały się wyrażenia wskazujące na brak stabilizacji wynikający z sytuacji rodzinnej, wymagającej interwencji policji: „kilka interwencji” (przedstawiciele animacyjnych organizacji społecznych), „zabranie dziecka z interwencji” (asystenci rodziny).

\section{Procedura prawna}

W ramach tej kategorii wyróżniono pojęcia odnoszące się do oddzielenia dziecka od rodzica czy rodziców, co w kontekście omawianych przypadków burzyło poczucie bezpieczeństwa dziecka, nawet jeśli miało na celu zabezpieczenie jego dobra. Ponadto w ramach tej kategorii wyodrębniono także pojęcia dotyczące poddania wykonywania władzy rodzicielskiej nadzorowi kuratora sądowego. W tym kontekście trzeba zauważyć, że choć ustanowienie kuratora stanowi zarządzenie wydawane przez sąd opiekuńczy w celu ochrony dobra dziecka, jednak dochodzi do sytuacji, gdy rodzice go nie respektują, nastawiają dziecko nie tylko przeciwko sobie, ale i przeciwko kuratorowi. Kolejna grupa pojęć odnosząca się do opozycji dobra dziecka w tej kategorii to pojęcia dotyczące nieuregulowanej sytuacji prawnej dziecka. Jest to bardzo istotna opozycja, ponieważ wskazuje ona na systemowe przeszkody, które wpływają na realizację zasady dobra dziecka. Otóż dochodzi do sytuacji, w których sąd opiekuńczy 
nie pozbawia rodziców władzy rodzicielskiej, choć zachodzą trwałe przeszkody w jej wykonywaniu. Rodzice otrzymują kolejne szansy i trwa to aż do osiągnięcia przez dziecko pełnoletniości. Przesądza to o losie dziecka, które wraz z wiekiem traci szansę na przysposobienie i dorasta w rodzinie zastępczej lub w palcówce opiekuńczo-wychowawczej.

Pojęcia odnoszące się do "procedury prawnej” i jej przebiegu przywoływane były w badaniu pola semantycznego opozycji pojęcia "dobro dziecka” stosunkowo rzadko. Uzyskały one $2 \%$ wskazań. Odwołania do procedury prawnej miały najwyższą frekwencję w grupie badanych sędziów rodzinnych - stanowiły one $76 \%$ wszystkich wypowiedzi tej kategorii. W grupie pracowników socjalnych stanowiły one $12 \%$, a w grupach kuratorów rodzinnych oraz przedstawicieli sprofilowanych organizacji społecznych po 6\%. Odwołania do tej kategorii nie odnotowano w wypowiedziach asystentów rodziny oraz przedstawicieli animacyjnych organizacji społecznych. Frekwencja w tej kategorii w grupie badanych sędziów rodzinnych, podobnie jak w odniesieniu do kategorii „brak kontaktu”, wskazuje na obiektywizowanie doświadczeń w ramach społecznego podziału wiedzy. Kategoria ta miała niską frekwencję w pozostałych grupach, ponieważ ich przedstawiciele nie internalizują w ramach odgrywanych ról przebiegu procedury prawnej dotyczącej podopiecznych. Pracując z rodzinami i podejmując działania na rzecz dzieci, nie skupiają się na tym aspekcie wiedzy, który najczęściej związany jest z „wejściem” i „wyjściem” z systemu organizowania pomocy. Przebieg procedury prawnej oraz zabezpieczanie w jej ramach dobra dziecka jest prerogatywą sądu i sędziego.

W wypowiedziach badanych sędziów rodzinnych najszerszą grupą pojęć były wyrażenia odnoszące się do oddzielenia dziecka od rodzica czy rodziców, np.: „umieszczenie w placówce”; „odebranie dziecka”; „wszczęcie postępowania o pozbawienie władzy matki nad wszystkimi dziećmi”. W wypowiedziach sędziów pojawiły się też wyrażenia dotyczące ograniczenia władzy rodzicielskiej, np. „sprawa o ograniczenie”. Trzeba tu jeszcze raz wyraźnie podkreślić, że z wypowiedzi sędziów wynikało, iż choć co do zasady działania związane $z$ umieszczeniem dziecka poza rodziną mają służyć jego dobru, to jednak w danym momencie stanowią dla niego traumatyczne i bardzo trudne przeżycie, burzące poczucie bezpieczeństwa.

Sędziowie rodzinni zwracali także uwagę na okoliczności poddania wykonywania władzy rodzicielskiej nadzorowi kuratora sądowego, np. „występowanie kuratora”; „nadzór kuratora”. Tu warto odnieść się do sytuacji, w której matka niegodząca się na kontakty dziecka z ojcem straszyła je „przyjściem faszystów w mundurach” [funkcjonariusze policji towarzyszący kuratorowi - M.A.], którzy będą chcieli siłą zabrać dziecko od matki. W wypowiedziach sędziów rodzinnych do pojęć zaliczonych do kategorii „procedura prawna” włączono też takie, które odnoszą się do prób jej naruszenia, choć z narracji tak matki, jak i rodziców adopcyjnych wynikały intencje zgodne z dobrem dziecka, np.: „adopcja z obejściem całej procedury”; „adopcja z obejściem ośrodka adopcyjnego”. 
W wypowiedziach pracowników socjalnych pojawiły się tylko dwa wyrażenia zaliczone do kategorii „procedura prawna”, były to wypowiedzi dotyczące ograniczenia władzy rodzicielskiej: „ograniczenie władzy oraz ograniczenie władzy przez nadzór kuratora”. Z wypowiedzi tych wynikało, że podjęte działania o charakterze prawnym zaburzyły poczucie bezpieczeństwa dzieci, których dotyczyły. Podobnie można wyjaśnić pojedyncze wyrażenie zaliczone do kategorii „procedura prawna” odnotowane w grupie kuratorów rodzinnych: „umieszczenie dziecka w rodzinie zastępczej”. Z kolei w grupie przedstawicieli sprofilowanych organizacji społecznych odnotowano wyrażenie: „popełnienie przestępstwa na szkodę dziewczynki”. Dotyczyło ono zawiadomienia prokuratury o możliwości popełnienia przestępstwa molestowania seksualnego dziewczynki przez jej ojca.

\section{Kwestionowanie orzeczenia sądu}

„Kwestionowanie orzeczenia sądu” to kategoria, która podobnie jak kategoria „procedura prawna” zyskała najmniej wskazań w zakresie zestawienia sieci opozycji pojęcia „dobro dziecka” - jedynie $2 \%$. Najliczniej była ona reprezentowana w wypowiedziach pracowników socjalnych - stanowiła 71\% wszystkich wypowiedzi w tej kategorii. W wypowiedziach kuratorów stanowiła ona $18 \%$, natomiast w wypowiedziach przedstawicieli sprofilowanych organizacji społecznych $-12 \%$. Kategoria ta zawiera wyrażenia, z których wynika, iż zastosowana wobec dziecka forma uregulowania jego sytuacji prawnej została uznana przez respondenta za rozwiązanie nietrafne - godzące w „dobro dziecka”. Nie dziwi zatem to, że w wypowiedziach sędziów rodzinnych nie wystąpiły wyrażenia, które można byłoby przypisać do tej kategorii. Taki rozkład frekwencji także potwierdza przebieg społecznego podziału wiedzy pomiędzy badanymi środowiskami zawodowymi. Jest to także zbieżne z wnioskami płynącymi z analizy wyników badań w świetle metody opisowo-ilustracyjnej. Otóż w toku wywiadów to pracownicy socjalni oraz kuratorzy rodzinni wskazywali na sytuacje, w których nie zgadzali się oni z treścią postanowienia sądu opiekuńczego. Badani reprezentanci tych środowisk zawodowych podkreślali wówczas, że przyczyną tego stanu jest niewystarczająco wnikliwe zapoznanie się sędziego rodzinnego $\mathrm{z}$ materiałem dowodowym lub błąd w ocenie tego materiału.

Poniższe przykłady wskazują na to, że pracownicy socjalni kwestionują orzeczenia sądu opiekuńczego w kilku sytuacjach - gdy uważają, że sąd powinien umieścić dzieci poza rodziną, gdy sąd nie powinien zezwolić na powrót dzieci do środowiska z rodziny zastępczej czy placówki lub gdy sąd nie powinien umieścić dzieci poza rodziną, bo możliwa jest dalsza praca $\mathrm{z}$ rodziną, a zabranie dzieci godzi w ich dobro, np.: „powrót dzieci do domu”; „powrót dzieci do rodziców”; „konieczność zabrania dziecka z rodziny”; „niezabieranie dzieci przez sędziego”; „wyrywanie dzieci z domu”. Powyższe rozróżnienie dotyczy także odnotowanych wypowiedzi kuratorów: „umieszczenie dziecka w placówce”; „przebywanie w domu dziecka”; „wyjście dzieci z systemu przez 
pomyłkę”. W ramach tej kategorii w grupie przedstawicieli sprofilowanych organizacji społecznych zidentyfikowano dwa wyrażenia: „rozdzielenie dzieci” oraz „rozszerzenie kontaktów”. Z wypowiedzi rozmówców wynikało, że rozwiązania wynikające z orzeczenia sądu, ich zdaniem, godziły w dobro dziecka.

\section{Wnioski}

Jak wynika z analizy zestawienia sieci opozycji pojęcia „dobro dziecka”, za najistotniejsze przeciwieństwo tego pojęcia uznać trzeba „niezaspokojenie potrzeb dziecka”, przy czym potrzeby rozumiane są tu szeroko, nie tylko jako potrzeby materialne, ale i psychiczne, społeczne i emocjonalne Kolejne kategorie, które uzyskały duży odsetek wskazań w odniesieniu do wszystkich badanych środowisk zawodowych, to „stosowanie przemocy” wobec dziecka (17\%) oraz „uzależnienie rodzica czy opiekuna” (16\%). Z kolei 9\% wskazań dotyczyło „braku kontaktu z osobą bliską”, a 8\% „nieodpowiedniego traktowania” dziecka przez rodzica. Najmniej wskazań odnosiło się do „braku stabilizacji sytuacji dziecka”, przebiegu i zastosowania „procedury prawnej” oraz „kwestionowania orzeczenia sądu” dotyczącego sytuacji dziecka. Biorąc pod uwagę frekwencję w trzech najliczniejszych kategoriach, można sfomułować wniosek, że opozycję „dobra dziecka” stanowią czynniki, zachowania i zaniechania rodziców i opiekunów dziecka, które godzą w jego poczucie bezpieczeństwa.

Zebrany materiał badawczy potwierdził wiedzę utrwaloną w literaturze przedmiotu, a zagadnienia, które stanowią kategorie analityczne wyróżnione w sieci opozycji pojęcia „dobro dziecka”, wskazywane są w doktrynie i orzecznictwie jako trwałe przeszkody uniemożliwiające wykonywanie władzy rodzicielskiej oraz czynniki, których występowanie w rodzinie zwiększa ryzyko zaistnienia w niej zjawiska krzywdzenia dziecka. Jest to bardzo istotne, ponieważ o ile zwykle metoda analizy pola semantycznego demaskuje to, co nie zostało wypowiedziane czy nazwane przez respondentów, to w przypadku badania pola pojęcia „dobro dziecka” ujawniła ona, że sposób myślenia przedstawicieli badanych środowisk zawodowych jest zgodny z formalną narracją dotyczącą „dobra dziecka”. Potwierdza to bardzo wysoką samoświadomość badanych, co trzeba ocenić pozytywnie. Z kolei fakt, iż prezentują oni różne punkty widzenia, a zatem że obszary zobiektywizowanej społecznie wiedzy nie zawsze są tożsame, wskazuje na konieczność ich współpracy. Problemy, jakich doświadczają rodziny objęte pomocą czy nadzorem sądu, zwykle nie są przejściowe, a ich występowanie w trwały sposób utrudnia odzyskiwanie opieki nad dzieckiem. 


\section{Bibliografia}

Arczewska M., Dobro dziecka w perspektywie przedstawicieli wybranych środowisk zawodowych, Dom Wydawniczy Nomos, Kraków 2017.

Błeszyński J., Rodkiewicz-Ryżek A., Ochrona praw dziecka w świetle standardów polskich i międzynarodowych, „Pedagogia Christiana”, nr 2(30)/2012.

Cunningham H., Children and Childhood in Western Society Since 1500, Longman, New York 1995.

Czerederecka A., Rozwód a rywalizacja o opiekę nad dziećmi, Wydawnictwo LexisNexis, Warszawa 2010.

Haak H., Władza rodzicielska. Kodeks rodzinny i opiekuńczy. Komentarz, Towarzystwo Naukowe Organizacji i Kierownictwa, Torun 1995.

Od Deklaracji genewskiej do Konwencji o prawach dziecka. Rys historyczny, https:// brpd.gov.pl/sites/default/files/rpd stare/uploadfiles/04str 20 lat kopd historia.pdf (dostęp: 14.09.2018).

Prusinowska-Marek A., Zapewnienie bezpieczeństwa i pomoc dziecku w sytuacji kryzysowej. Praktyczny przewodnik dla osób pracujacych zdzieckiem i rodzina, Mazowieckie Centrum Polityki Społecznej, Warszawa 2015.

Robin R., Badanie pól semantycznych: doświadczenia Ośrodka Leksykologii Politycznej w Saint-Cloud, [w:] M. Głowiński (red.), Jezzyk i społeczeństwo, Czytelnik, Warszawa 1980.

Smyczyński T., Prawo rodzinne i opiekuńcze. System prawa prywatnego, Wydawnictwo Naukowe PWN, Warszawa 2005.

Stojanowska W., Rozwód a dobro dziecka, Wydawnictwo Prawnicze, Warszawa 1970. Van Den Berg J.H., Dziecko stało się dzieckiem, [w:] M. Janion, S. Chwin (red.), Dzieci, t. II, Wydawnictwo Morskie, Gdańsk 1988.

\section{Child welfare from the perspective of family judges and social services in the context of supporting the biological family in regaining custody over the child}

Abstract: The decision about placing a child outside his or her family is difficult for the representatives of the institutions involved in the process of helping the family. The representatives might feel they have failed in their efforts. This decision also determines the future of the child and the possibility of maintaining the bond with his or her biological parents and siblings. Moreover, the decision about returning the child to the family is usually hard and associated with a risk of failure. It needs to be said that reintegration and regaining custody over the child by his or her biological parents should be the focus of the activities taken by social services and their representatives in aid of families. The aim of this article is to discuss the difficulties that might arise in the context of supporting the natural family in regaining custody over the child. In order to illustrate these difficulties, the author presents the results of her own studies in which she carried out an analysis of the semantic field related to the "welfare of the child", which included an analysis in relation to the following professional groups: family judges, professional probation officers, social workers, family assistants and representatives of two kinds of social organisations, those with a defined profile of activity and those involved in social animation. 
Keywords: best interest of the child, child, family, Family Court, social welfare, social work, social services

About the author: Magdalena Arczewska - PhD in humanities, sociologist and lawyer, works as an adjunct at the Institute of Applied Social Sciences of the University of Warsaw. Arczewska is a trainer, researcher and evaluator with several years of experience in working in Poland and abroad. Specialises in research on social policy and cooperation of public administration with non-governmental organisations at the government and local levels. Arczewska is a Member of the Board of the Family Judges Association in Poland. 
Małgorzata Karczmarzyk* (iD https://orcid.org/0000-0001-9906-9574

Uniwersytet Gdański

Dominika Szelągowska**

III Liceum Ogólnokształcące w Gdańsku

\title{
Analiza wizualno-werbalna wybranych książek dla dzieci o biografiach sławnych artystów malarzy
}

DOI: 10.25312/2083-2923.15/2019_07mkds

\begin{abstract}
Streszczenie: Na rynku wydawniczym pojawiło się w ostatnim czasie wiele interesujących książek obrazkowych dla dzieci, które nie tylko mają w zamierzeniu uczyć dziecko, ale również wychowywać je przez sztukę i uwrażliwiać estetycznie. Wiele z nich poświęconych jest również biografiom artystów malarzy. W jaki sposób wybrane książki dla dzieci przedstawiają obraz artysty, okaże się w trakcie analizy wizualno-werbalnej niektórych pozycji, opisanych w niniejszym artykule. Wybrane do analizy książeczki obrazkowe dla dzieci to np.: L. Anholt, Van Gogh. Kamil i słoneczniki; E. Carle, The artist who painted a blue horse; D. Remerts, Meneer Kandinsky was een Schiller; M. Valenzia, Getting to know the world's greatest artists, oraz polskie: A. Czerwińska-Rydel, Mgnienie oka. Opowieść o Danielu Mikołaju Chodowieckim; M. Kowerko-Urbańczyk, Idol. Frida Kahlo.
\end{abstract}

Słowa kluczowe: książka obrazkowa dla dzieci, analiza wizualno-werbalna, wychowanie przez sztukę, artysta malarz

\section{Wprowadzenie do tematu}

Na polskim i zagranicznym rynku wydawniczym pojawiło się w ostatnim czasie wiele interesujących pozycji dla dzieci, które nie tylko uczą, ale również wychowują i uwrażliwiają estetycznie dziecko. Współczesne polskie wydawnictwa promujące do-

\footnotetext{
* Małgorzata Karczmarzyk - artysta, tutor, nauczyciel akademicki, adiunkt w Pracowni Edukacji Medialnej Uniwersytetu Gdańskiego.

** Dominika Szelągowska - nauczyciel sztuki w III Liceum Ogólnokształcącym w Gdańsku.
} 
brą literaturę dziecięcą to np.: Dwie Siostry, Bajka, Literatura, Widnokrąg. Pokazują się zarówno pozycje monograficzne, jak i czasopisma pedagogiczne i literaturoznawcze na temat utworów dzieci poświęconych ludziom nauki i sztuki. Są to artykuły i książki K. Zabawy, w których autorka posługuje się terminem ikonotekstu, analizując integralną całość tekstu oraz ilustracji; prace A. Ungeheuer-Gołąb, wprowadzającej dziecko w wieku przedszkolnym w świat literatury rozwijającej ważne potrzeby emocjonalne, intelektualne, społeczne dziecka ${ }^{1}$; publikacje M. Cackowskiej, która tworzy kategorię książki obrazkowej dla dzieci²; prace K. Wądolny-Tatar i M. Chrobak, które ujawniają w analizowanych tekstach z zakresu literatury dla dzieci i młodzieży infantylizowanie odbiorcy poprzez stosowanie uproszczonych form i środków wyrazu $^{3}$; a także artykuły A. Wincencjusz-Patyny, która opisuje np. transimaginację, analizując problem obrazowania rysunkiem utworów literackich ${ }^{4}$. Inni polscy autorzy zajmujący się literaturą dla dzieci to m.in.: G. Leszczyński, A. Steliga, O. Pajączkowski oraz B. Olszewska. Zagraniczne opracowania poświęcone temu tematowi to m.in.: Picturebooks, Pedagogy and Philosophy J. Haynes i K. Murris; Children's Picturebooks. The Art of Visual Storytelling M. Salisbury'ego i M. Styles oraz Crossover Picturebooks. A Genre for All Ages S.L. Beckett.

$\mathrm{W}$ niniejszym artykule $\mathrm{z}$ całego arsenału polskiej i zagranicznej literatury dla dzieci zostanie wybranych kilka pozycji, nawiązujących do szeroko rozumianego pojęcia wychowania przez sztuki plastyczne ${ }^{5}$. Konkretnie chodzi o analizę propozycji dotyczących problematyki sztuki i życia bohemy artystycznej, a zwłaszcza środowiska plastyków.

Modelowy artysta malarz jest spadkobiercą tradycji romantycznej, co wymaga by był on osobą emocjonalną, buntowniczą, nierzadko nieszczęśliwą, postępującą w niekonwencjonalny i nieprzewidywalny sposób, wyposażony przy tym w wewnętrzną siłę i imperatyw twórczy, a do tego trwający w opozycji do świata ${ }^{6}$. Tak więc konwencja wymaga od artysty bycia niekonwencjonalnym. A tego rodzaju opis zakrawa na ironię i daje obraz tego, jak łatwo i skutecznie stereotypy mogą przenikać do powszechnej świadomości społecznej. We współczesnej rzeczywistości zaś zbyt często mamy do czynienia z niszczeniem wrażliwości, tępieniem estetyki i ograniczaniem twórczości plastycznej dziecka poprzez np. obcinanie godzin przeznaczonych na zajęcia plastyczne w szkołach, niedofinansowanie szkół w zakresie materiałów pla-

${ }^{1}$ Zob. A. Ungeheuer-Gołąb, Literackie inspiracje w rozwoju przedszkolaka, Stowarzyszenie Bibliotekarzy Polskich, Warszawa 2012.

2 Zob. J. Szyłak, H. Dymel-Trzebiatowska, M. Cackowska (red.), Książka obrazkowa. Wprowadzenie, Instytut Kultury Popularnej, Poznań 2017.

${ }^{3}$ Zob. K. Wądolny-Tatar, M. Chrobak, Światy dzieciństwa, Universitas, Kraków 2016.

${ }^{4}$ Zob. A. Wincencjusz-Patyna, Między słowem a obrazem - kiedy rysunek staje się ilustracja, „DYSKURS. Pismo Naukowo-Artystyczne ASP we Wrocławiu”, t. 16/2013.

${ }^{5}$ Zob. I. Wojnar, Estetyka i wychowanie, PWN, Warszawa 1970.

${ }^{6}$ Zob. M. Janion, M. Zielińska (red.), Style zachowań romantycznych. Propozycje i dyskusje. Sympozjum, Warszawa 6-7 grudnia 1982 r., PIW, Warszawa 1986. 
stycznych czy też brak sal przeznaczonych na działania stricte artystyczne. Podręczniki i zadania w edukacji wczesnoszkolnej nie dają uczniom możliwości wyjścia poza schematyczny i odtwórczy sposób ekspresji plastycznej ${ }^{7}$.

Jak pisze B. Mazepa-Domagała, „Dzisiejsza rzeczywistość niszczy naturalne wartości widzenia i odczuwania świata, niszczy wrażliwość zwykłych ludzi. Te wartości mają szansę odrodzenia się poprzez przywrócenie sztuce jej podstawowych znaczeń"8.

Analizując wybrane książki dla dzieci o biografiach sławnych artystów malarzy, chcemy podtrzymać tę dewizę odradzania się wartości w sztuce poprzez zainteresowanie nią młodego czytelnika, ale z drugiej strony chcemy krytycznie spojrzeć na niektóre z propozycji wydawniczych, aby wybrać te najwartościowsze i cieszyć się sztuką już od najmłodszych lat.

\section{Komentarz metodologiczny}

W części empirycznej artykułu zostanie przeanalizowanych kilka wybranych książek dla dzieci, z rynku polskiego i międzynarodowego, na temat biografii sławnych artystów malarzy. Ze względu na kompilację obrazu i tekstu w tego rodzaju propozycjach zastosowano metodę analizy wizualno-werbalnej stworzoną przez Gunthera Kressa i Theo van Leeuwena'. To oni pierwsi analizowali tego rodzaju propozycje, opisując strukturę wizualno-werbalną tekstów, ich kompatybilność, praktyki kulturowe i zasady specyficznej gramatyki wizualnej, którymi posłużę się również w mojej analizie.

W artykule analizowane będą między innymi struktury i formy wiedzy zawarte w wybranych książkach na temat biografii sławnych artystów malarzy, praktyki proponowane lub narzucane dziecku, dyskursy konstruowane za pośrednictwem ww. książek, postawy estetyczne, socjalizacja do kultury, a także wzorce kulturowe i społeczne oswajane przez dziecko ${ }^{10}$.

${ }^{7}$ M. Karczmarzyk, Wybrane podręczniki dla klas pierwszych edukacji zintegrowanej - analiza metoda wizualno-werbalna Guntera Kressa oraz Theo van Leeuwena, „Chowanna”, nr 2(41)/2013, s. 303-313.

${ }^{8}$ M. Mazepa-Domagała, Z zagadnień recepcji sztuki przez dziecko. Próba określenia kompetencji odbiorcy wytworów sztuki i przyszłego ich twórcy, [w:] K. Krasoń, B. Mazepa-Domagała (red.), Wymiary ekspresji dziecięcej. Stymulacja - samorealizacja - wsparcie, Librus-Górnośląska Wyższa Szkoła Pedagogiczna im. Kardynała Augusta Hlonda, Katowice-Mysłowice 2005, s. 41.

9 Zob. G. Kress, T. van Leeuven, Reading images. The Grammar of Visual Design, Routledge, London-New York 1996.

${ }^{10}$ M. Karczmarzyk, N. Pater-Ejgierd, A child in a virtual gallery. The analysis of selected websites of great museums, „Problemy Wczesnej Edukacji”, nr 2(12)/2010, s. 133-141. 


\section{Wybrane książki dla dzieci o biografiach sławnych artystów malarzy}

Przykładem publikacji, która prezentuje utarty wizerunek artysty, jest książka pt.: The artist who painted a blue horse (czyli „Artysta, który namalował błękitnego konia" ${ }^{11}$ ). W propozycji zastosowano kompilację obrazu i słowa, z przewagą komunikatów wizualnych. Ilustracje wypełniają bowiem całą kartkę formatu A4, zaś komunikaty werbalne to zdania pojedyncze bądź wyrazy uzupełniające się wzajemnie z ilustracją. Struktura wizualno-werbalna całości zatem jest kompatybilna i tworzy ikonotekst ${ }^{12}$.

Komunikaty wizualne występują zwykle w trybie żądającym, to znaczy, że kierują uwagę odbiorcy i wymagają z nim kontaktu. Tego rodzaju dyskurs może wynikać z formuły całej książki, która jest swego rodzaju manifestem autora. Pokazuje on bowiem siebie jako „dobrego artystę". Dyskurs egocentryczny jest więc tutaj wskazany, tym bardziej że swoje ilustracje podkreśla komunikatem werbalnym. Oto, co pisze autor:

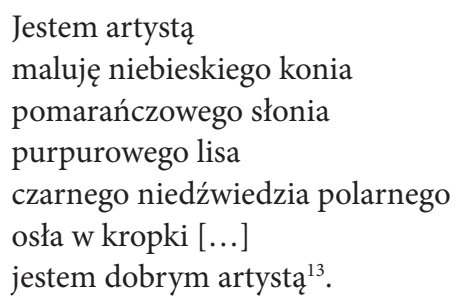

Autor, artysta i rysownik, to trochę również buntownik, zmieniający powszechnie obowiązujące reguły, działający według własnych praw oraz widzący świat w odmienny, indywidualny sposób, przefiltrowany przez odrębną osobliwą wrażliwość. Dlatego modalność jego ilustracji jest wysoka. Świat stworzony przez artystę nie musi być bowiem rzeczywisty. Nie musi być rozpoznawalny i podobny do tego, co wszyscy znamy z najbliższego otoczenia. Taka formuła jest powszechnie akceptowana i nikogo nie dziwi, bo przecież artysta wszystko może, a jego świat jest inny i odmienna jest jego percepcja.

Omawiana tutaj książka Erica Carle jest szczególnym przypadkiem jednostronnego ukazania idei artyzmu, ponieważ stanowi jego artystyczne credo, będące owocem własnych doświadczeń. Dla dziecięcego odbiorcy stanowić może czynnik wpływu, decydujący o postawie, jaką obierze on wobec zjawisk związanych ze sztuką i tworzących się w ten sposób schematów i stereotypów na temat wizerunku artysty.

${ }^{11}$ Zob. E. Carle, The artist who painted a blue horse, Philomel Books, 2011 (tłum. tytułu własne K.M.).

${ }^{12}$ K. Zabawa, Literatura dla dzieci w kontekstach edukacyjnych, Wydawnictwo WAM, Kraków 2017.

13 Tłumaczenie D. Szelągowska. 
Kolejną publikacją, która zasługuje na uwagę, jest książka pt.: Menner Kandinsky was een Schilder (czyli „Pan Kandinski był malarzem”) ${ }^{14}$, autorstwa Daana Remmerts de Vries, opowiada o Wassilim Kandinskim i jego malarstwie. W baśniowej anegdocie autor pokazuje drogę, jaką ów malarz przebył od przedstawień realistycznych, przez ekspresjonizm, aż do abstrakcji. Tekst werbalny jest kompatybilny z ilustracją i przeplata się z nią zarówno na stronach tytułowych książki, jak również w części środkowej opowieści.

Kandinski jest tutaj pogrążonym we własnym świecie, roztargnionym artystą, który w codziennym życiu dokonuje zabawnych pomyłek i przejęzyczeń, wynikających z nieustającego zaabsorbowania malarstwem. Pędzi na niebieskim koniu poprzez fantastyczne krajobrazy, szukając weny, i dla swej imaginacji przekracza własne granice. Jest to droga artysty natchnionego, ekscentryka i wizjonera. Dyskurs emancypacyjny, w którym stworzona jest ta opowieść, może otworzyć młodego czytelnika na świat sztuki. Tego rodzaju podejście, osadzone w myśleniu rewolucyjnym, poszukiwaniu odmienności, realizowaniu własnych celów, jest bardzo potrzebne młodemu pokoleniu. Otwiera je bowiem na myślenie twórcze i kreatywne. Pokazuje świat sztuki z lekkim przymrużeniem oka, ale w taki sposób, że chce się tą malarską drogą podążać.

Jeszcze inny obraz artysty, tym razem określonego cierpieniem, prezentuje książka Laurence Anholt pt.: Kamil i słoneczniki ${ }^{15}$, opowiadająca o Vincencie van Goghu. Niewątpliwie tragiczna biografia tego malarza stała się w zasadzie popkulturowym mitem, który zaprezentowany jest również w tej publikacji.

Malarz jest określany terminami: „dziwny przybysz” lub „dziwny pan”, które można by przyporządkować do dyskursu wykluczenia. Autor tej opowieści bowiem, opisując swojego bohatera, nieświadomie stawia go poza nawias społeczeństwa.

W książce akcentowane zostaje ubóstwo i osamotnienie artysty, który spotyka się z odrzuceniem i niezrozumieniem, jest niedoceniany i niesprawiedliwie osądzany. Van Gogh jest tu postacią jednowymiarową, zredukowaną do geniuszu i nieszczęśliwego życia. Młodemu czytelnikowi podaje się w ten sposób nie tyle informacje o malarzu i jego twórczości, co ich interpretację. Dlatego też warto sprawdzić, jaką właściwie wizję na temat artysty posiadają dzieci i czy wpływa ona w znaczący sposób na kształtowanie ich sądów na ten temat. Pamiętajmy, że dziecko mogło już się zetknąć z potoczną wiedzą na temat van Gogha z racji oglądania przeróżnych komunikatów medialnych docierających do niego z różnych źródeł. Ostatnio emitowany w kinach film biograficzny o tragicznej śmierci tego artysty zupełnie inaczej pokazuje jego sylwetkę. Każdy z nas może inaczej oceniać tę biografię, a tym bardziej małe dziecko, które dopiero wchodzi w otaczającą je kulturę. Dlatego jego interpretacje mogą być odmienne i bardzo oryginalne.

\footnotetext{
14 Zob. D. Remerts, Meneer Kandinsky was een Schiller, Leopold, 2010.

15 Zob. L. Anholt, Van Gogh. Kamil i słoneczniki, Sterdust Media S.C., 2011.
} 
Ukazało się również w ostatnim czasie kilka pozycji o bardziej rzeczowym charakterze, pozbawionych tego swoistego stygmatyzowania artystycznego świata. W bardzo konkretny i przyjazny sposób przybliża sylwetki najbardziej znanych artystów seria wydawnicza Getting to know the world's greatest artists (czyli „Poznając najsłynniejszych artystów”), napisana i dowcipnie zilustrowana przez Mike’a Valenzię ${ }^{16}$. Nie ma tu niepotrzebnej afektacji, uwznioślania artystycznych profesji. Za przykład może posłużyć zdanie zaczerpnięte z książki opowiadającej o życiu i twórczości Andy’ego Warhola: „Twórcy pop-artu, jak Andy Warhol, Claes Oldenburg i Roy Lichtenstein robili po prostu to, co artyści zawsze robili. Tworzyli sztukę o rzeczach, które były ważne i obecne w ich codziennym życiu"17.

Zdanie to uderza swą otwartością, prostotą i bezpretensjonalnością. Taki sposób przekazywania wiedzy o świecie sztuki uwalnia ją w jakimś stopniu od postromantycznej kalki, przez jaką w mniej lub bardziej świadomy sposób prezentuje się ją dopiero wchodzącemu w świat kultury odbiorcy. Wydaje się, że jest to wartościowa i inspirująca forma zapoznania młodego czytelnika ze zjawiskami artystycznymi, sprzyjająca otwartemu, pozbawionemu niepotrzebnego dystansu, kształtowaniu samodzielnych opinii na temat dzieł sztuki i ich twórców.

Inną pozycją, tym razem pochodzącą z polskiego rynku wydawniczego, jest Mgnienie oka. Opowieść o Danielu Mikołaju Chodowieckim A. Czerwińskiej-Rydel. Jest to książeczka obrazkowa dla dzieci o jednym z najbardziej znanych ilustratorów książek XVIII wieku, Danielu Mikołaju Chodowieckim. Snuta przez autorkę opowieść pozwala towarzyszyć bohaterowi w podróży z Berlina do Gdańska w 1773 roku (odwiedziny swej matki). W ten sposób oglądamy Gdańsk oczyma człowieka oświecenia i jest to widzenie inne niż to, do którego przywykliśmy, patrząc na nasze miasto dzień w dzień.

Czerwińska-Rydel stosuje różne strategie kreowania biografii artystów, nie tylko ludzi sztuki, ale również ludzi nauki. Tego rodzaju niestereotypowe opisy zmieniają ogólne, schematyczne podejścia do artysty znanego jako buntownika, biedaka, geniusza albo szaleńca.

Jedną z pozycji, którą warto pokrótce poddać analizie, jest interaktywny zeszyt ćwiczeń, w którym młody czytelnik, wykonując specjalnie przygotowane zadania, poznaje kulisy pracy malarki - Fridy Kahlo. Dziecko dowiaduje się, co jest potrzebne artystce, by tworzyć obraz, jak namalować autoportret, a jak martwą naturę. Może również stworzyć własną kolekcję sztuki meksykańskiej czy przygotować wystawę $\mathrm{w}$ galerii sztuki ${ }^{18}$. Jednym $\mathrm{z}$ ćwiczeń jest możliwość ubrania Fridy w jej meksykańskie stroje. Tego rodzaju działania na pewno urozmaicają trudny przekaz odnoszący się do artyzmu i sztuki wymienionej autorki. Przepełniona cierpieniem biografia Fridy

${ }_{16}$ Zob. M. Valenzia, Getting to know the world's greatest artists, Children's Press, 1996.

17 Tamże, s. 6-7, tłumaczenie własne: M. Karczmarzyk.

${ }_{18}$ Frida Kahlo. Seria Idol, https://www.znak.com.pl/ksiazka/frida-kahlo-seria-idol--99922 (dostęp: 20.09.2018). 
uwidacznia się bowiem w jej obrazach, a przez to może być mało atrakcyjna dla młodego czytelnika. Z badań realizowanych przez M. Karczmarzyk od 2013 roku wynika, że obrazy Kahlo nie są pozytywnie odbierane przez młodych ludzi ze względu na zbyt wiele odniesień osobistych ${ }^{19}$. Artystka jest uważana przez dzieci w wieku wczesnoszkolnym za „brzydką” m.in. przez zrośnięte brwi, które przeczą współczesnemu wizerunkowi zadbanej, wystylizowanej, ale również „zrobionej” kobiety, ukazującej się w reklamach telewizyjnych czy na ulicznych plakatach.

Problem estetyzacji społeczeństwa, o którym pisał onegdaj W. Welsch ${ }^{20}$, jest tutaj kluczowy. Nie wszystkie bowiem ilustracje czy animacje komputerowe wychowują młodego odbiorcę pozytywnie. Problem ten jest szczególnie istotny i wkracza w dyskusyjny aspekt ilustracji, która pełni bardzo istotną funkcję w wychowaniu dziecka i traktowaniu go jako partnera w dialogu o sztuce ${ }^{21}$.

To, w jaki sposób będziemy rozmawiać o sztuce $\mathrm{z}$ dzieckiem i jakie obrazy oraz ilustracje będziemy mu pokazywać, w przyszłości wpłynie na jego gust oraz zainteresowanie lub też samowykluczenie kulturowe.

\section{Podsumowanie analiz}

Przeanalizowane publikacje, z jednej strony, są przykładami ukazania sylwetki artysty jako kulturowego destylatu przekonań i oczekiwań dotyczących tej grupy osób. Nie podejmuje się w nich próby przełamania ustanowionej konwencji, a zamiast świadomego kształtowania młodego czytelnika mamy do czynienia z bezrefleksyjną reprodukcją rozpowszechnionej kalki na temat twórców sztuk plastycznych.

$\mathrm{Z}$ drugiej jednak strony, jest wiele propozycji przełamujących ten impas. $\mathrm{Na}$ szczęście, polska ilustrowana książka dziecięca odradza się po trudnym okresie przystosowywania się do funkcjonowania na wolnym rynku i obecnie wyłoniło się grono zdolnych i docenianych, również za granicą, polskich pisarzy i ilustratorów.

Książki obrazkowe dla dzieci w wieku wczesnoszkolnym, które powinniśmy dla nich wybierać, muszą rozwijać ciekawość poznawczą dziecka, wzmacniać wiarę we własne możliwości w dziedzinie aktywności twórczej, poddawać refleksji działania w obszarze edukacji o artystach malarzach, czy też innych ludziach nauki i sztuki. Jest to konieczne, aby najmłodsze pokolenie potrafiło odnaleźć swoje miejsce w świecie współczesnej kultury.

19 Zob. M. Karczmarzyk, O. Lewandowska-Walter, A. Wasilewska, Co dzieci myślą o życiu, religii i sztuce. Dziecko a tematy trudne, Wydawnictwo Harmonia, Gdańsk 2016.

${ }^{20}$ Zob. W. Welsch, Estetyka i anestetyka, [w:] R. Nycz (red.), Postmodernizm. Antologia przekładów, Wydawnictwo Baran i Suszyński, Kraków 1998.

21 M. Cackowska, Czym jest książka obrazkowa? O pojmowaniu książki obrazkowej w Polsce, część I, „Ryms”, nr 5/wiosna 2009, s. 5; część II, „Ryms”, nr 6/lato 2009, s. 14-16; część III, „Ryms”, nr 8/zima 2009/2010, s. 12-13. 


\section{Podsumowanie analiz w kontekście praktyki pedagogicznej}

Z punktu widzenia praktyki pedagogicznej należałoby uważnie przyjrzeć się działaniom podejmowanym przez szkołę. Edukacja artystyczna w placówkach szkolnych, w takiej formie, w jakiej w obecnie jest prowadzona, nie daje dzieciom większych możliwości wykształcenia bardziej otwartej postawy wobec sztuki. Pomijając treści zawarte w podręcznikach, wątpliwości może też budzić ich szata graficzna. W większości przypadków ilustracje w nich zawarte nie wychodzą poza banalną, dziecięcą estetykę, w której próżno dopatrywać się jakichkolwiek wartości artystycznych ${ }^{22}$. Wydaje się, że jest to zmarnowana szansa na umożliwienie dziecku stałego dostępu do materiałów graficznych o walorach artystycznych, czyli do stałego kontaktu ze sztuką graficzną w prosty i naturalny sposób.

Źle przeprowadzona edukacja plastyczna w późniejszych latach przynosi smutne konsekwencje. U uczniów pojawia się dojmujące przekonanie o własnej nieudolności w tej dziedzinie, częściowo charakterystyczne dla wieku, lecz wzmocnione i solidnie ugruntowane przez rozbudowany system oceniania i ukierunkowywania aktywności plastycznych.

Dla szkoły interesujące mogą być przykłady działań prowadzone przez różnego rodzaju animatorów oraz organizacje i instytucje, jak na przykład galeria Zachęta ${ }^{23}$, Spotlight Kids ${ }^{24}$ czy galeria Bunkier Sztuki ${ }^{25}$. Są to warsztaty z udziałem artystów plastyków, którzy współtworzą z dziećmi pełne rozmachu projekty. Są to przedsięwzięcia związane z tematyką sztuki - głównie współczesnej. Forma ich realizacji to dynamiczne zajęcia w specjalnie do tego przygotowanych pomieszczeniach, $\mathrm{z}$ dostępem do rozmaitych mediów, materiałów plastycznych, gdzie dzieci są zachęcane do dowolnego dysponowania udostępnionymi środkami, brudzenia się, tworzenia spontanicznych scenariuszy z pomocą edukatorów pasjonatów. W warunkach szkolnych jest to rzecz jasna utopia, niemożliwa do zrealizowania jako działania programowe. Może jednak stanowić wzór nadający kierunek prowadzonym zajęciom, określać filozofię proponowanego przekazu. Wydaje się, że każda zmiana polegająca na odejściu od skostniałego schematu jest zmianą na lepsze. Należałoby upowszechnić wiedzę o istotności kształtowania u dzieci nie tylko umiejętności plastycznych i znajomości wiedzy o sztuce, lecz może przede wszystkim twórczej postawy jako cechy osobowości, do czego wspaniałym narzędziem może być właśnie sztuka.

${ }^{22}$ M. Karczmarzyk, dz. cyt., s. 303-313.

${ }^{23}$ https://zacheta.art.pl/pl (dostęp: 18.05.2019).

${ }^{24}$ https://artmuseum.pl/pl/wydarzenia/spotlight-kids (dostęp: 18.05.2019).

${ }^{25}$ http://bunkier.art.pl/ (dostęp: 17.05.2019). 


\section{Bibliografia}

Anholt L., Van Gogh. Kamil i słoneczniki, Sterdust Media S.C., 2011.

Cackowska M., Czym jest książka obrazkowa? O pojmowaniu książki obrazkowej w Polsce, część I, „Ryms”, nr 5/wiosna 2009; część II, „Ryms”, nr 6/lato 2009; część III, „Ryms”, nr 8/zima 2009/2010.

Carle E., The artist who painted a blue horse, Philomel Books, 2011.

http://bunkier.art.pl/ (dostęp: 17.05.2019).

https://artmuseum.pl/pl/wydarzenia/spotlight-kids (dostęp: 18.05.2019).

https://www.znak.com.pl/ksiazka/frida-kahlo-seria-idol--99922 (dostęp: 20.09.2018). https://zacheta.art.pl/pl (dostęp: 18.05.2019).

Janion M., Zielińska M. (red.), Style zachowań romantycznych. Propozycje i dyskusje. Sympozjum, Warszawa 6-7 grudnia 1982 r., PIW, Warszawa 1986.

Karczmarzyk M., Co znacza rysunki dziecięce? Znaczenia i potencjał komunikacyjny rysunku dziecka sześcioletniego, Wydawnictwo UG, Gdańsk 2010.

Karczmarzyk M., Wybrane podręczniki dla klas pierwszych edukacji zintegrowanejanaliza metoda wizualno-werbalna Guntera Kressa oraz Theo van Leeuwena, „Chowanna”, nr 2(41)/2013.

Karczmarzyk M., Pater-Ejgierd N., A child in a virtual gallery. The analysis of selected websites of great museums, „Problemy Wczesnej Edukacji”, nr 2(12)/2010.

Kress G., van Leeuwen T., Reading images. The Grammar of Visual Design, Routledge, London-New York 1996.

Limont W., Nielek-Zawadzaka K., Dylematy edukacji artystycznej, T. 1: Edukacja artystyczna wobec przemian w kulturze, Oficyna Wydawnicza Impuls, Kraków 2005.

Mazepa-Domagała M., Z zagadnień recepcji sztuki przez dziecko. Próba określenia kompetencji odbiorcy wytworów sztuki i przyszłego ich twórcy, [w:] K. Krasoń, B. Mazepa-Domagała (red.), Wymiary ekspresji dziecięcej. Stymulacja-samorealizacja - wsparcie, Librus-Górnośląska Wyższa Szkoła Pedagogiczna im. Kardynała Augusta Hlonda, Katowice-Mysłowice 2005.

Remerts D., Meneer Kandinsky was een Schiller, Leopold, 2010.

Rose G., Interpretacja materiałów wizualnych. Krytyczna metodologia badań nad wizualnością, Wydawnictwo Naukowe PIW, Warszawa 2010.

Szyłak J., Dymel-Trzebiatowska H., Cackowska M. (red.), Książka obrazkowa. Wprowadzenie, Instytut Kultury Popularnej, Poznań 2017.

Ungeheuer-Gołąb A., Literackie inspiracje w rozwoju przedszkolaka, Stowarzyszenie Bibliotekarzy Polskich, Warszawa 2012.

Valenzia M., Getting to know the world's greatest artists, Children's Press, 1996.

Wądolny-Tatar K., Chrobak M., Światy dzieciństwa, Universitas, Kraków 2016.

Welsch W., Estetyka i anestetyka, [w:] R. Nycz (red.), Postmodernizm. Antologia przekładów, Wydawnictwo Baran i Suszyński, Kraków 1998. 
Wincencjusz-Patyna A., Między słowem a obrazem - kiedy rysunek staje się ilustracja, „DYSKURS. Pismo Naukowo-Artystyczne ASP we Wrocławiu”, t. 16/2013.

Wojnar I., Estetyka i wychowanie, PWN, Warszawa 1970.

Zabawa K., Literatura dla dzieci w kontekstach edukacyjnych, Wydawnictwo WAM, Kraków 2017.

\section{Visual-verbal analysis of selected picture book biographies of famous painters}

Abstract: Illustrated books for children seek to educate children through art and make them aesthetically attuned. Many of these books are devoted to the biographies of painters. This article outlines how selected children's books present artists, and offers a visual-verbal analysis. The texts analysed include: L. Anholt, Van Gogh. Kamil i stoneczniki; E. Carle, The artist who painted a blue horse; D. Remerts, Meneer Kandinsky was een Schiller; M. Valenzia, Getting to know the world's greatest artists; and Polish ones, e.g.: A. Czerwińska-Rydel, Mgnienie oka. Opowieść o Danielu Mikołaju Chodowieckim; M. Kowerko-Urbańczyk, Idol. Frida Kahlo.

Keywords: children's picture book, visual-verbal analysis, education through art, artist

About the authors: Małgorzata Karczmarzyk - artist, tutor, academic teacher, assistant professor at the Media Education Workshop of the University of Gdansk. Dominika Szelągowska - art teacher in III High School in Gdansk. 


\title{
Agnieszka Domagała-Kręcioch* (D) https://orcid.org/0000-0001-9823-2552
}

Uniwersytet Pedagogiczny w Krakowie

\section{Refleksje wokół szkolnej kultury błędu}

DOI: $10.25312 / 2083-2923.15 / 2019+05 a d k$

\begin{abstract}
Streszczenie: Współczesny świat podporządkowany jest walce o sukces, do którego droga prowadzi przez wiele pomyłek, błędów, niepowodzeń. Bardzo ważnym elementem pracy szkoły jest więc kształtowanie takich kompetencji, dzięki którym uczniowie będą mogli prawidłowo funkcjonować w rzeczywistości zmiennej, niepewnej, nieprzewidywalnej. Celem niniejszego artykułu jest próba ukazania konieczności budowania szkolnej kultury błędu, dzięki której łatwiejszy może być start w dorosłość. W tekście zostały wyodrębnione warunki niezbędne do tworzenia szkolnej kultury błędu i omówione, na podstawie badań przeprowadzonych wśród młodych dorosłych, trzy podstawowe zagadnienia $\mathrm{z}$ nią związane, tj.: rola szkoły w jej budowaniu, postawy wobec błędów oraz reakcje na nie nauczycieli i osób uczących się.
\end{abstract}

Słowa kluczowe: szkolna kultura błędu, szkoła, doświadczenia edukacyjne, uczeń dorosły

\section{Wprowadzenie}

Szkoła jest instytucją, która zgodnie z przyjętymi celami i zadaniami, zajmuje się przygotowaniem człowieka do funkcjonowania w dorosłym życiu. Zdaniem R. Schulza, szkoła to swojego rodzaju „organ edukacyjny”, który poprzez swoje ujednolicenie i przyjęte normy ma rozwiązywać jeden z ważniejszych problemów społecznych, tzn. przekazywać istotne składniki obowiązującej kultury młodemu pokoleniu ${ }^{1}$.

Zinstytucjonalizowanie edukacji sprawia, że szkoła podlega wszystkim regułom właściwym instytucjom społecznym, wraz z podziałem funkcji i z normatywnymi formami działalności. Użycza fizycznej (jako budynku) i interakcyjnej przestrzeni (wraz z uregulowanymi relacjami pomiędzy uczestnikami szkolnego życia), a także udostępnia specyficzny szkolny język do uprawomocnia-

* Agnieszka Domagała-Kręcioch - pedagog, socjoterapeuta. Jej zainteresowania naukowe koncentrują się wokół szkoły i dokonujących się w jej obszarze zmian. Prowadzi badania dotyczące znaczenia doświadczeń edukacyjnych dla społecznego funkcjonowania człowieka dorosłego.

${ }^{1}$ R. Schulz, Szkoła - instytucja - system - rozwój, PWN, Toruń 1992. 
nia kulturowych systemów wymiany. Szkoła ma stałe miejsce na społecznym rynku, gdzie od najmłodszych lat dzieci uczą się, co jest warte nabycia (jakie rodzaje, zakresy wiedzy, umiejętności, zachowań), aby móc to wymienić na określone przywileje. Nauczyciele [...] na co dzień zobligowani są do ciągłego oceniania uczniów i dzielenia ich na „lepszych i gorszych” tak, aby przygotować ich do sprawnego podejmowania odpowiednich ról w innych instytucjach społecznych ${ }^{2}$.

Takie podejście, choć odkrywa prawdziwe oblicze edukacji, niestety stoi w opozycji do ogólnie przyjętych założeń i zapisów statutowych, czy nawet ministerialnych, bowiem w tych najważniejszych dyrektywach oświatowych model współczesnej szkoły ma zaspokajać indywidualne potrzeby uczniów, a tym samym spełniać oczekiwania osób zaangażowanych w edukację, od ucznia zaczynając, a na społeczności lokalnej kończąc. Przede wszystkim jednak ma uwzględniać aktualny kierunek społecznych i kulturowych zmian, stając się przede wszystkim przestrzenią do osiągnięcia sukcesu, tak ważnego w kulturze osiągnięć. Jak zauważa L. Sałaciński, szkoła w takim podejściu powinna być miejscem: „gdzie nie ma przegranych ani wygranych, gdzie wszyscy czują się bezpiecznie, gdzie panuje demokratyczne partnerstwo między poszczególnymi podmiotami, gdzie każdy z tych podmiotów z satysfakcją uczestniczy w codziennym twórczym działaniu" 3 .

Co więcej, zdaniem Z. Melosika, to właśnie edukacja (a przez to m.in. i szkoła) ma umożliwić ludziom wybór sposobów życia, dzięki którym możliwy będzie ich rozwój. Jednak, w przekonaniu autora, życie współczesnego człowieka bardzo często podporządkowane jest idei rywalizacji o sukces, co prowadzi do podziału na "zwycięzców” $\mathrm{i}$ „całą resztę”, a niejednokrotnie brak własnego sukcesu przekształca się w pragnienie klęski innych ${ }^{4}$. Jest to zjawisko o tyle niebezpieczne, że jak zauważa T. Borowska, człowiek przez całe swoje życie czerpie nie tylko z wewnętrznych zasobów, ale podlega wpływom otaczającego go środowiska i ludzi w nim funkcjonujących. Zachowania człowieka w dużym stopniu wynikają z przyjętych w danej społeczności wzorców interpretacyjnych, jednak w sytuacjach nowych, nieprzewidywalnych nie zawsze wzorce te działają i wtedy reakcja człowieka jest sprawdzianem jego wewnętrznej siły ${ }^{5}$. Dlatego ważnym elementem pracy z uczniami (w tym również uczniami dorosłymi) jest kształtowanie takich kompetencji, które pozwolą im na prawidłowe funkcjonowanie w społeczeństwie podlegającym nieustannym przemianom. Wśród kompetencji, które są niedoceniane w środowisku szkolnym, a stanowią istotny element funkcjonowa-

${ }^{2}$ Cyt. za: S. Krzychała, B. Zamorska, Zamknięte i otwarte zmiany kultury szkoły, [w:] B.D. Gołębniak, H. Kwiatkowska (red.), Nauczyciele. Programowe (nie)przygotowanie, WNDSW, Wrocław 2012, s. 59.

${ }^{3}$ L. Sałaciński, Wstęp, [w:] L. Sałaciński, W. Theim (red.), Szanse na sukces w szkole. Nauczyciel wobec nowych wymagań, Uniwersytet Zielonogórski, Zielona Góra 2003, s. 5-6.

${ }^{4}$ Z. Melosik, Postmodernistyczne kontrowersje wokó edukacji, Wydawnictwo Edytor, PoznańToruń 1995.

${ }^{5}$ T. Borowska, Pedagogia ograniczeń ludzkiej egzystencji, IBE, Warszawa 2003, s. 16. 
nia w społeczeństwie sukcesu, znajduje się m.in. nauka na błędach, będąca ważnym elementem szkolnej kultury błędu.

Przegląd najważniejszych teorii andragogicznych (np. Paradygmat Wartości Oczekiwanej K. Rubensona czy Model Łańcucha Interakcji P. Cross) pokazuje, że u podstaw aktywności edukacyjnej osób dorosłych znajdują się uprzednie doświadczenia związane między innymi ze stopniem zaspokajania potrzeb czy postawą wobec edukacji, uzależnioną od występowania lub braku znaczących porażek edukacyjnych ${ }^{6}$.

Jeżeli chodzio samo pojęcie „kultura szkoły”,to można powiedzieć,żewystępujeono w bardzo wielu tekstach dotyczących edukacji czy szkoły ${ }^{7}$. Zdaniem M. Czerepaniak-Walczak, w przestrzeni szkolnej pojawia się wiele kultur (edukacji, zaufania, interakcji, pedagogiczna, uczniowska, ciszy czy kultura milczenia) oraz wskazuje się na różne ich wymiary. Tak więc, uwzględniając odmienne kryteria, można mówić np. o:

- kulturze kobiecej i kulturze męskiej;

- kulturze zaufania paternalistycznego i kulturze zaufania krytycznego ${ }^{8}$;

- kulturze typu: „rodzina”, „wieża Eiffla”, „pocisk sterowany”, „inkubator”.

Niniejsze rozważania koncentrują się na szkolnej kulturze błędu, która ze względu na kulturowy charakter dążenia do osiągania sukcesu pozostaje w jego tle i stanowi wciąż element ukrytego programu szkoły. Ze względu na to, iż nie funkcjonuje w polskiej literaturze pedagogicznej definicja kultury błędu, przyjęto, że szkolna kultura błędu to ogół przekonań, poglądów i postaw wobec błędów popełnianych przez uczniów i nauczycieli oraz sposób reagowania na nie. Uwzględniając podejście do błędów, zaproponowane przez N. Keith i M. Frese, można rozróżnić dwa sposoby reagowania na nie:

- zapobieganie błędom,

- radzenie sobie $\mathrm{z}$ błędami ${ }^{10}$.

Ze względu na doświadczenia, jakie może dostarczać nauka na błędach, drugi sposób podejścia wydaje się zdecydowanie korzystniejszy w przypadku sytuacji szkolnych i tworzenia warunków do budowania szkolnej kultury błędów. Jednak,

6 M. Malewski, Teorie andragogiczne. Metodologia teoretyczności dyscypliny naukowej, Wydawnictwo Uniwersytetu Wrocławskiego, Wrocław 2001.

${ }^{7}$ Zob. np.: M. Czerepaniak-Walczak, Kultura szkoły - o jej złożoności i wielowymiarowości, „Pedagogika Społeczna”, nr 3(57)/2015, s. 77-87; K. Polak, Kultura szkoły. Od relacji społecznych do języka uczniowskiego, Wydawnictwo Uniwersytetu Jagiellońskiego, Kraków 2007; M. Dudzikowa, S. Jaskulska (red.), Twierdza. Szkoła w metaforze militarnej. Co w zamian?, Wolters Kluwer, Warszawa 2016; J. Bruner, Kultura edukacji, Universitas, Kraków 2010; U. Dernowska, A. Tłuściak-Delikowska (red.), Kultura szkoły. Studium teoretyczno-empiryczne, Oficyna Wydawnicza Impuls, Kraków 2015.

${ }^{8}$ M. Czerepaniak-Walczak, dz. cyt., s. 77-87.

${ }^{9}$ F. Trompenaars, Ch. Hampden-Turner, Siedem wymiarów kultury: znaczenie różnic kulturowych w działalności gospodarczej, Oficyna Ekonomiczna, Kraków 2002.

${ }^{10}$ N. Keith, M. Frese, Enhancing firm performance and innovativeness trough error management culture, [w:] N.M. Ashkanasy, C.P.M. Wilderom, M.F. Peterson (red.), Handbook of organizational culture and climate, Thousand Oaks, CA, Sage Publications, London 2011. 
by kulturę tę można było budować w określonej przestrzeni, powinny być spełnione pewne podstawowe warunki:

1) uważność w dostrzeganiu błędów, bez której trudno kształtować umiejętności uczenia się na błędach;

2) zgoda (otwartość) na popełnianie błędów; stwarzanie warunków zaspokajających potrzebę bezpieczeństwa zarówno w przypadku uczniów, jak i nauczycieli, bowiem - jak zauważa K. Polak - brak zaspokojonej potrzeby bezpieczeństwa w przestrzeni szkolnej wymusza nastawienie na ciągłą obronę siebie i swoich potrzeb, co zabiera niepotrzebnie energię ${ }^{11}$, uwagę i czas;

3) wykorzystywanie popełnianych błędów do budowania wiedzy negatywnej będącej rodzajem metapoznania, dzięki któremu, na podstawie uprzednio popełnionych błędów, jednostka wie, jak postąpić (czego nie robić) w przyszłości. Sposób zarządzania negatywną wiedzą wpływa na skuteczność jednostek i grup społecznych ${ }^{12}$;

4) branie odpowiedzialności za własne działanie. Chodzi tutaj naturalnie zarówno o odpowiedzialność nauczyciela, jak i czynienie współodpowiedzialnym za podejmowane lub niepodejmowane działania samego ucznia. W nowoczesnym procesie uczenia się sytuacje edukacyjne powinny stanowić źródło doświadczeń, dzięki którym poznawanie świata staje się ciekawe i warte uwagi, niezależnie od, a może właśnie dzięki popełnianym błędom;

5) posiadanie odpowiednich kompetencji, dzięki którym człowiek przygotowany jest do uczenia się na własnych i cudzych błędach (np. otwartość, poczucie własnej wartości, radzenie sobie w sytuacjach nowych, radzenie sobie z własnymi emocjami);

6) współpraca rodziców, uczniów, nauczycieli. W związku z tym, że edukacja współczesnego człowieka nie rozpoczyna się dopiero w szkole i w szkole też się nie kończy, bardzo ważna jest współpraca tych podmiotów, które najmocniej zaangażowane są w rozwój jednostki.

Brak podłużnych badań nad skutkami niewłaściwego reagowania na błędy w przestrzeni szkolnej, czego konsekwencją są m.in. niepowodzenia edukacyjne, nie daje możliwości właściwego oszacowania strat osobistych, społecznych czy kulturowych, jakie ponosi jednostka i społeczeństwo, jednak jak pokazują wycinkowe badania, skala tego zjawiska nie jest mała. Pomimo dokonujących się zmian i postępu technologicznego współczesność nasza, jak zauważa Z. Kwieciński, „jest obciążona nakładającymi się na siebie zaległościami rozwojowymi, nieszczęściami, patologiami i błędami przeszłości, uwikłana w pełne napięć i trudności szybkie zmiany teraźniej-

11 K. Polak, dz. cyt.

12 F. Oser, M. Spychiger, Lernen ist schmerzhaft. Zur Theorie des negativen Wissens und zur Praxis der Fehlerkultur [Learning is painful. On the theory of negative knowledge and the practice of error culture], Weinheim, Beltz 2005. 
sze" ${ }^{\prime 3}$. Czy wobec tego, podążając za autorem, pedagodzy i inne osoby zaangażowane w edukację powinni pogodzić się z faktem, że „tyle jednostek ludzkich było i jest bez ich winy - zablokowanych w rozwoju, bezradnych wobec "pośpiechu i cynizmu « ładu kapitalistycznego, zagubionych w [...] świecie histerii informacyjnej?" 14 .

Chociaż „edukacja ma dwie główne funkcje: socjalizację i wyzwalanie”, w kontekście powyższego pytania zasadna staje się teza, że edukacja, w tym edukacja dorosłych, nieustannie pełni tę pierwszą, czyli przygotowuje człowieka do życia w społeczeństwie, „które kontroluje nasze ruchy, [...] kształtuje naszą tożsamość, nasze myśli i uczucia"15, w społeczeństwie, które nas zniewala. Jak zauważa P. Dominicé, gdyby ludzie dorośli tematem własnych biografii uczynili ocenianie szkolne, to mielibyśmy obraz tego, jak oceny, wyróżnienia, ale i kary, wpływają na kształt życia człowieka. „W przypadku wielu dorosłych, system oceniania w szkole sprawił, że zaczęli wątpić we własne możliwości. Stopnie postrzegane są często jako coś więcej niż informacja na temat przyswojonej wiedzy. [...] Nie tyle jednak stopnie, jako takie, są powodem surowej oceny siebie, ile sposób w jaki są one interpretowane przez środowisko społeczne i samych uczniów"16, dlatego budowanie kultury błędu wydaje się tak istotne.

Od lat popełniane są te same błędy, gdyż brak krytycznej refleksji nie pozwala dostrzec konieczności wprowadzania zmian tam, gdzie są najbardziej potrzebne. Zmieniane są programy nauczania, wprowadzane nowe metody i wykorzystywane nowoczesne technologie. Dużo czasu zostaje zmarnowane na to, by najpierw tworzyć gimnazja, po to, by za chwilę je likwidować i narażać uczniów na dodatkowy stres. Zmusza się uczniów do noszenia mundurków, by za chwilę powracać do relatywnej wolności w ubieraniu się. Poprawiane jest to, co zewnętrzne, pomija się natomiast fakt, że uczniowie mają problemy z emocjami, nauczyciele są przeciążeni nadmiarem biurokracji i zestresowani, bo nie mają wsparcia psychologicznego i rodzicielskiego. Rodzice stawiają coraz więcej oczekiwań i wymagań względem szkoły, sami nie podejmując żadnych starań. Nic zatem dziwnego, że szkoła „ocenia, stawia stopnie, naznacza, selekcjonuje, sortuje, blokuje świadomość ciągłości międzypokoleniowej [...], zabija krytyczną mądrość społeczną, a w tym wrażliwość na los słabszych (»przecież oni naprawdę byli niedostateczni«)"17.

${ }^{13}$ Z. Kwieciński, Długotrwałe ślady szkolnego dzieciństwa, [w:] R. Piwowarski (red.), Dziecko. Sukcesy i porażki, IBE, Warszawa 2007, s. 119.

${ }_{14}$ Tamże, s. 120.

15 P.L. Berger, Zaproszenie do socjologii, PWN, Warszawa 1995, s. 115.

${ }^{16}$ P. Dominicé, Uczyć się zżzycia. Biografia edukacyjna w edukacji doroslych, Wydawnictwo Wyższej Szkoły Humanistyczno-Ekonomicznej, Łódź 2006, s. 179.

17 Z. Kwieciński, dz. cyt., s. 120. 


\section{Metodologia}

Na podstawie obserwacji środowiska pedagogicznego można zaryzykować tezę, że pomimo dostrzegania określonego podejścia do błędów w polskiej szkole niestety oficjalnie nie funkcjonuje termin „kultura błędu”. Tezę tę potwierdzają przeprowadzone przez autorkę badania ankietowe w grupie 171 osób przyszłych pedagogów studentów studiów pedagogicznych. W badanej grupie dominowały kobiety. Celem badań było poznanie wycinka szkolnej rzeczywistości dotyczącej budowania szkolnej kultury błędu. Badani zostali poproszeni o wypełnienie kwestionariusza ankiety, który koncentrował się wokół trzech podstawowych pytań:

1. Jaką rolę odgrywa szkoła w tworzeniu warunków do budowania kultury błędu?

2. Jakie postawy przyjmują badani wobec popełnianych błędów własnych i cudzych?

3. Jak badani reagują na popełniane błędy?

\section{Rola szkoły w budowaniu kultury błędu}

W Polsce jest zapewne dużo szkół, które próbują nadążać za wyzwaniami codzienności i zmierzają do budowania wartościowych wspólnot; niestety wciąż istnieją i takie, w których czas się zatrzymał. Zdaniem R. Kwaśnicy, współczesna szkoła to instytucja „uzasadniona potrzebami sprzed, bez mała, 150 lat. Powołano ją, oczywiście w uproszczeniu, żeby kształcić rzesze jednakowo przygotowanych urzędników, masowe kadry dla rozwijającego się przemysłu, no i zdolnych wojskowych dla masowych armii"'18. Pomimo upływu lat szkoły działają podobnie i nawet szereg deklaracji i aspirowania do społeczeństwa inteligentnego i sprawiedliwego nie zmienia szkoły w znaczącym stopniu. Jak dalej zauważa R. Kwaśnica, „zaakceptowaliśmy racjonalność szkoły, uznaliśmy, że jest to rozwiązanie konieczne, naturalne i innego nie ma. I to jest nasza kulturowa oczywistość, która podtrzymuje byt szkoły w dzisiejszym kształcie"19.

Od wielu lat i pomimo szeregu zmian w debacie o edukacji wciąż pojawiają się te same zarzuty pod adresem polskiej szkoły:

- przedmiotowe traktowanie uczniów;

- przeładowany program szkolny;

- nauka wkuwania, a nie myślenia;

- brak miejsca na zarządzanie błędami;

- niezdrowa rywalizacja, z przestarzałym systemem oceniania;

${ }^{18}$ Taka szkoła nie jest nam potrzebna, https://www.newsweek.pl/polska/co-trzeba-zmienic-w -polskiej-szkole-jak-reformowac-edukacje/51hs06t (dostęp: 4.03.2019).

19 Tamże. 
- brak autentycznej nauki współpracy; wciąż uczniowie siedzą plecami do siebie, co nie sprzyja właściwym relacjom;

- przekazywanie wiedzy teoretycznej bez praktycznego jej zastosowania;

- marginalizacja i stygmatyzacja słabszych ${ }^{20}$.

Do listy tej można także dołączyć brak w programach nauczania treści o ludzkiej psychice, kształceniu umiejętności poznawczych, metapoznawczych czy społecznych.

Rozmowy z nauczycielami potwierdzają fakt, że w ich świadomości pokutuje przekonanie, zgodnie z którym do swoich najważniejszych obowiązków zaliczają przygotowanie uczniów do tego, by byli bardzo dobrymi i dobrymi uczniami, a nie dorosłymi. Podejmują w tym kierunku wiele działań, nie zawsze troszcząc się o ich konsekwencje. Jak zauważa H. Majewska, pomimo tego, że dziecko „ma zdolność nadawania znaczeń poszczególnym zdarzeniom, jest bardzo wpływowe, a co za tym idzie, staje się łatwym celem do wszelkich manipulacji i działań indoktrynacyjnych"21. Na dodatek, już na etapie wczesnej edukacji szkolnej, pojawia się szereg trudności w wypełnianiu społecznej roli ucznia, co - w obliczu pojawiających się zagrożeń i braku poczucia bezpieczeństwa - skłania wiele jednostek do minimalizowania kosztów psychicznych i przyjmowania postawy obronnej. W sytuacji permanentnie odczuwanego zagrożenia młodym, zagubionym w przestrzeni szkolnej i życiowej ludziom trudno jest budować swoją przyszłość $^{22}$. Konsekwencją takiej sytuacji może być pojawiająca się w dalszym życiu bezradność, frustracja, neurotyzm. Jak twierdzi R. Izdebski, prowadzone są obecnie grupy terapeutyczne dla młodych dorosłych, którzy są zagrożeni wykluczeniem nie dlatego, że mieli złe rodziny czy umysły, ale dlatego, że nie narodził się w nich dorosły ${ }^{23}$.

Analizę zgromadzonego materiału empirycznego rozpoczęto od rozumienia przez badanych samego określenia: „szkolna kultura błędu”. Zestaw udzielonych odpowiedzi pokazał, że pojęcie to definiowane jest przez badanych dość wąsko, jako wyolbrzymianie błędów (co być może wynika z podejścia do popełniania błędów w polskiej szkole) i kojarzone jest przede wszystkim z uczniem; to uczniowie popełniają błędy, za które często są karani. Tylko nieliczne osoby wskazywały, że „pojęcie to odnosi się do błędów pojawiających się w szkołach zarówno ze strony uczniów, jak i nauczycieli oraz sposobów odnoszenia się do nich, i prób lub zaniechań poprawienia ich"24.

${ }^{20}$ M. Jarkowiec, Na górze naczelnik dyrektor, pod nim klawisze-nauczyciele, na dole więźniowie-uczniowie. Sto lat polskiej szkoły. Wyborcza.pl. Dodatek świąteczny, http://wyborcza.pl/magazyn/7,124059,24144426,na-gorze-naczelnik-dyrektor-pod-nim-klawisze-nauczyciele-na.html (dostęp: 10.12.2018).

${ }^{21}$ H. Majewska, Kim uczyniła mnie szkoła?, [w:] D. Klus-Stańska (red.), Dokąd zmierza polska szkoła?, Wydawnictwo Żak, Warszawa 2008, s. 339.

22 K. Polak, dz. cyt.

23 R. Izdebski, B. Brzyski, Powierzyć dziecko światu, https://klubjagiellonski.pl/2016/07/15/izdebski-powierzyc-dziecko-swiatu (dostęp: 17.12.2019).

${ }^{24} \mathrm{~W}$ tekście zostały zachowane oryginalne wypowiedzi badanych. 
Kultura błędu nabiera wyjątkowego znaczenia w kontekście panującej kultury sukcesu. W związku z tym, że szkoła stanowi jedno z ważniejszych miejsc promowania sukcesu, staje się też odpowiedzialna za właściwe przygotowanie zarówno uczniów, jak i nauczycieli do jego osiągnięcia. Poprzez konstruktywne podejście do błędów, czy formułowanie i przestrzeganie zasad sprzyjających uczeniu się na i z błędów, szkoła odgrywa zasadniczą rolę w budowaniu kultury przyjaznej osobom w niej funkcjonującym.

O tym, jak szkoła, do której uczęszczali badani, podchodzi do popełnianych błędów, dowiadujemy się z kolejnych wypowiedzi respondentów. Na pytanie o charakter szkolnej kultury błędu w przestrzeni szkoły najczęściej pojawiała się odpowiedź „trudno powiedzieć” (78\%). Jedynie 10\% badanych stwierdziło, że ma ona charakter „konstruktywny”.

W budowaniu kultury szkoły ważne są zasady, które kształtują stosunek do innych osób, do poglądów, głoszonych i wyznawanych praw. W szkołach, które stanowiły środowisko uczenia się badanych, były najczęściej stosowane następujące zasady:

- kto popełnia błędy, powinien ponieść konsekwencje (76,5\%);

- błędy/niepowodzenia są tak samo ważne jak osiąganie sukcesów (64,7\%);

- każdy ma prawo do popełniania błędów (58,8\%);

- dobry uczeń nie popełnia błędów $(47,1 \%)$;

- jeśli chcesz mieć dobre stopnie, rób to, czego oczekuje nauczyciel (47,1\%);

- nauczyciel nigdy się nie myli (41,2\%);

- sprytny jest ten, kto nie da się przyłapać na popełnianiu błędów $(29,4 \%)^{25}$.

Sporządzony zestaw zasad pokazuje, że z jednej strony pojawia się w przestrzeni szkoły zgoda na traktowanie błędów jako ważnych składowych osiągnięć - „są tak samo ważne jak sukcesy” i „każdy ma prawo do ich popełniania”. Z drugiej jednak strony wyraźnie zaznaczona jest tendencja do unikania błędów, gdyż za nie grożą konsekwencje, i sprytny jest ten, kto ich nie popełnia. Badani wskazywali także na nieomylność nauczyciela, co powoduje, że podejście do błędów przybiera formę negacji i unikania. Taka sytuacja czyni z nauczycieli ludzi nieomylnych i staje się nie tylko przyczyną codziennego stresu, ale także powodem zakłóconych relacji. Jak wskazuje M. Jarkowiec: „Nauczyciele mają problem z budowaniem relacji z uczniami. Nikt ich nie nauczył jak to się robi, i oni nie uczą tego uczniów. Jak potem, w dorosłym życiu, mamy budować dobre relacje w rodzinie, sąsiedztwie, w pracy, polityce? Jak mamy powiększać wzajemne zaufanie, kapitał społeczny?"26. Jeżeli trudno jest przyznać się do błędu, ale łatwo wytyka się błędy innym, nie powinien dziwić fakt, że nie tylko zabraknie miejsca na otwarty i szczery dialog nauczyciela z uczniami, ale także pojawi się problem $z$ budowaniem zaufania i poczucia bezpieczeństwa. Tymczasem potrzeba bezpieczeństwa to „jeden z najważniejszych czynników organizujących zachowanie człowieka"27. Jeżeli szkoła nie stwarza odpowiednich warunków pozwalających na za-

\footnotetext{
${ }^{25}$ Badani mieli możliwość wskazania więcej niż jedną odpowiedź.

${ }^{26}$ M. Jarkowiec, dz. cyt.

${ }^{27}$ K. Polak, dz. cyt., s. 78.
} 
spokajanie tej potrzeby, uczniowie przejawiają takie formy zachowania, jak: agresja, apatyczność, bierność, wycofanie, i działają według bezpiecznych dla siebie stereotypowych form zachowania. Zgodnie z raportem Fundacji Dzieci Niczyje, w 2015 roku największą grupę osób korzystających z pomocy online, udzielanej w ramach międzynarodowego projektu Pomoc dzieciom w trudnych sytuacjach, stanowiły nastolatki. Według szacunków, co czwartym (26\%) nadawcą przesłanej wiadomości była osoba w wieku 13-15 lat, a co piąta w wieku 16-17 lat. I co prawda, wśród występujących problemów te związane bezpośrednio ze szkołą stanowiły $25 \%$ wszystkich zgłaszanych problemów, jednak jeśli dodamy 23\% problemów z relacjami rówieśniczymi i 35\% związanych ze zdrowiem psychicznym i problemów psychospołecznych ${ }^{28}$, to rysuje nam się obraz polskiej szkoły, która tylko pozornie wypełnia swoje funkcje społeczne.

\section{Postawa wobec błędów}

W budowaniu szkolnej kultury błędu istotna staje się odpowiednia postawa wobec potknięć, gaf, omyłek innych i własnych.

Jak przekonują N. Kerth i M. Frese, błędy i pomyłki są podstawową kategorią wszystkich ludzkich działań, jednak większość ludzi postrzega błędy jako zdarzenia negatywne, ponieważ kojarzą błędy z negatywnymi konsekwencjami ${ }^{29}$.

Popełnianie błędów może wynikać z różnych przyczyn. Może mieć związek z brakiem doświadczenia, z nieumiejętnością radzenia sobie z własnymi emocjami, z brakiem wiedzy czy z aktualnym stanem zdrowia. E. Jaworska dokonała zestawienia różnych przyczyn popełniania błędów w uczeniu się z uwzględnieniem czynników wewnętrznych i zewnętrznych ${ }^{30}$.

Szkoła $z$ reguły wymaga od ucznia bezbłędności i jako „instytucja formalna, odgórnie definiuje oraz narzuca uczniom i nauczycielom ich role wraz z całą gamą różnorodnych oczekiwań względem nich" ${ }^{31}$. Uczniowie mogą bać się własnych błędów i unikać przyznawania się do ich popełnienia z co najmniej kilku powodów. Wśród nich znajdują się m.in.:

- niepewność co do reakcji rówieśników;

- obawa, że błędy wpłyną negatywnie na ich ocenę, egzamin, przyszłość;

- próba uniknięcia kary ${ }^{32}$.

${ }^{28}$ Pomoc online dzieciom $w$ trudnych sytuacjach życiowych. Specyfika problemów zgłaszanych przez dzieci, http://fdds.pl/wp-content/uploads/2016/05/Zurkowska Pomoc online dzieciom w trudnych sytuacjach zyciowych.pdf (dostęp: 12.02.2019).

${ }^{29}$ N. Keith, M. Frese, dz. cyt.

30 E. Jaworska, Uczenie się na błędach - wybrane zagadnienia, „Folia Pomeranae Universitatis Technologiae Stetinensis, Oeconomica”, nr 311(75)2/2014, s. 67-74.

31 U. Dernowska, A. Tłuściak-Deliowska, dz. cyt., s. 14.

32 E. Jaworska, dz. cyt. 
Na pytanie: Czy bałeś się popełniania błędów w szkole?, badana grupa niemalże w $100 \%$ odpowiedziała „tak”. Wśród najczęściej podawanych powodów pojawiały się właśnie strach i obawa przed ośmieszeniem („boję się popełniać błędy, bo każdy jest przez nauczyciela wyciągany przed klasą”), troska o swoją przyszłość („ambitni uczniowie dążą do perfekcji, a każdy błąd staje się dla nich przeszkodą; błędy traktowane są jako finał jakiegoś procesu, a nie kolejny etap dochodzenia do celu"), strach przed ocenianiem. Dane te są pewnym zaskoczeniem, gdyż wśród pozytywnych konsekwencji popełnianych błędów respondenci dostrzegali m.in.: kształtowanie zachowań prospołecznych, radzenie sobie z emocjami, radzenie sobie z trudnymi sytuacjami, umiejętność poszukiwania właściwych rozwiązań, budowanie dystansu do siebie, nauka wytrwałości, uczenie się rozróżniania tego, co naprawdę jest ważne, umiejętność życia w oceniającym i nietolerancyjnym społeczeństwie, wypracowanie mechanizmów pozwalających dostosować się do zmieniającego się otoczenia itd. Ta bogata lista różnych umiejętności i kompetencji pokazuje, że tego, czego szkoła powinna uczyć w sposób czytelny i otwarty, niestety nie uczy ${ }^{33}$, bo wypiera błędy i karze za ich popełnianie, spychając szkolną kulturę błędu do ukrytego programu szkoły.

Zdaniem respondentów, istnieje także pewna grupa uczniów, dla których popełnianie błędów postrzegane jest jako działanie korzystne, ale w nieco odmiennym znaczeniu. Wśród takich uczniów znajdują się ci, „którzy chcą na siłę zaistnieć, oni celowo popełniają błędy i ci, którzy manifestacyjnie chwalą się błędami, bo im nie zależy na zdobywaniu wiedzy", jednak z takimi osobami szkoła nie umie sobie radzić, karząc je drugorocznością, złymi ocenami i uwagami. Sytuacja taka wzmacnia niestety negatywną postawę wobec błędów wśród uczniów, dla których sukces nabiera ważnego, życiowego znaczenia.

\section{Reakcje na błędy}

Dokonując obserwacji szkolnych zachowań uczniów i nauczycieli w kontekście popełnianych błędów, można zauważyć jedną z poniższych reakcji:

1) „Nic się nie wydarzyło” - w sytuacjach błahych, w przypadku braku wiedzy i informacji zwrotnej, uczeń w ogóle nie wie, że popełnił błąd, więc zachowuje się tak, jakby nic się nie stało;

2) „To nie ja zrobiłem” - negacja, wypieranie i nieprzyznawanie się do popełnionego błędu, zwłaszcza wtedy, gdy grożą poważne konsekwencje;

3) „Tak, zrobiłem to” - akceptacja pomyłki, przyznanie się do niej niezależnie od konsekwencji.

Ważnym elementem reakcji jednostki na błędy jest zachowanie nauczyciela i społeczności szkolnej, która często staje się świadkiem danej sytuacji czy zajścia. Mając

${ }^{33}$ Zob. A. Domagała-Kręcioch, B. Majerek, Czego (nie)uczy szkoła?, „E-mentor”, nr 1(53)/2014, http://www.e-mentor.edu.pl/artykul/index/numer/53/id/1080 (dostęp: 20.11.2018). 
na uwadze ten fakt, oczekuje się, że nauczyciel powinien być świadomy skutków podejmowanych działań i przejawianych reakcji, co związane jest z jego odpowiedzialnością edukacyjną. Zdaniem L. Sałacińskiego,

[...] rozpatrując istotę odpowiedzialności nauczyciela, mówimy o bezpośrednim zdaniu się jednego człowieka na drugiego, i to w takiej zależności, że jeden drugiemu, z własnej woli, oferuje gotowość pomocy w jego rozwoju i doskonaleniu. [...], istota drugiego człowieka, z którym nauczyciel wchodzi w interakcyjny układ, jest postrzegana w ściśle określony sposób. Jest postulatywnym obrazem przyszłego człowieka, będącym dla nauczyciela dokładnie określonym celem działania, który nie zawsze może się wydobyć i ukształtować sam z siebie. Chodzi tu więc o byt przyszły człowieka, który jest przede wszystkim ważny dla niego samego, ale samodzielnie nie potrafi się uformować i w związku z tym potrzebuje wsparcia i pomocy ${ }^{34}$.

Nieodpowiedzialny nauczyciel nie jest w stanie kształtować u swoich uczniów poczucia odpowiedzialności za swoje działania, edukację i życie, co skutkuje brakiem odpowiedzialności u ludzi dorosłych ${ }^{35}$. Brak odpowiedniego wsparcia ze strony nauczyciela, jego niewłaściwa postawa i trudne warunki szkolne zdają się jeszcze bardziej utrudniać proces porzucania roli ucznia i wchodzenia w dorosłe życie z przekonaniem o własnej skuteczności i braniem odpowiedzialności za siebie i innych.

Chociaż szokujące mogą wydawać się słowa: „Zastanawiam się, jaki stosunek do świata, do państwa i do bliźnich kształtuje osiem lat upokorzeń ze strony belfrów na oczach rówieśników. Z jakimi emocjami taki »leniwy nieuk « wchodzi w wiek młodzieńczy, a potem w dorosłość?" ${ }^{36}$, to mimo wszystko uzyskane w trakcie badań dane pokazują, że nie ma w tych słowach żadnej przesady.

$\mathrm{Na}$ pytanie o to, jak reagowali nauczyciele i koledzy na popełniane przez badanych błędy, pojawiła się niestety długa lista reakcji negatywnych i dość krótka pozytywnych przejawów troski i wsparcia. Na liście pierwszej znalazły się między innymi: krytykują, krzyczą, porównują do lepszych uczniów, ignorują, wyśmiewają, karzą, denerwują się, obgadują, izolują, wytykają palcami, dokuczają, cieszą się z niepowodzenia, wyśmiewają się, zawstydzają, ośmieszają, kpią, żartują sobie. Wśród reakcji pozytywnych badani wskazywali na: wyjaśniają, próbują pomóc, dają drugą szansę, tłumaczą, dopingują. Jeśli chodzi o uczucia i reakcje samych badanych na popełniane błędy, to pojawiały się wśród nich następujące: stresowałam się; robiłam się czerwona; zamykałam się w sobie; rozpamiętywałam; czułam, że zawiodłam siebie i innych; czułam, że poniosłam porażkę; wstyd; czułam się głupio, ale potem przywykłam do takich sytuacji; bałam się, co sobie pomyślą inni; złość; rozczarowanie; błaznowałam;

${ }^{34}$ L. Sałaciński, Obowiązek, odpowiedzialność oraz powinność aksjologiczna nauczyciela, [w:] L. Sałaciński, W. Theim (red.), Szanse na sukces w szkole. Nauczyciel wobec nowych wymagań, Uniwersytet Zielonogórski, Zielona Góra 2003, s. 42-43.

35 Tamże.

${ }^{36}$ M. Jarkowiec, dz. cyt. 
zawstydzenie; agresja; niechęć; rezygnacja. Zdecydowanie rzadziej respondenci wskazywali na chęć poprawienia błędu albo obojętność z nim związaną.

W kontekście takich danych rodzi się zasadnicze pytanie: na jakich dorosłych wyrosną osoby, które narażone były na ciągłą krytykę, wyśmiewanie, pozostawiane same sobie?

\section{Zakończenie}

Metamorfoza szkoły nie jest możliwa błyskawicznie; na to potrzeba tygodni, miesięcy, a może nawet lat. Pamiętać powinni o tym ci, którzy odpowiadają za rozwój człowieka na każdym etapie jego życia, bo ziarno zasiane w dzieciństwie przyniesie plon w dorosłym życiu. Kiedy nauczyciel mówi do ucznia: „Zawsze popełniasz te same błędy, nie słuchasz tego co mówię, nie zdasz egzaminu”, często skutkuje to utratą zainteresowania i chęci. Mówienie: „Jesteś niegrzeczny” albo „Jesteś nieukiem” jest poniżające, jest ono obelgą i znieważaniem, natomiast w żadnym wypadku nie jest poprawianiem. Poprawianie bowiem oznacza, że człowiek staje się lepszy, ale jak można tego dokonać przez poniżanie dziecka, które już znalazło się w trudnościach? ${ }^{37}$.

Zatem jedynie dzięki odpowiednim warunkom stwarzanym między innymi przez szkołę i uczących w niej nauczycieli młody człowiek ma potencjalną możliwość stać się osobą zaangażowaną, gotową i zdolną do współdziałania, nie zatracając przy tym swej wrażliwości, szacunku dla wartości wyższych oraz bezinteresownego działania na rzecz innych ludzi ${ }^{38}$. Może warto więc podjąć trud budowania szkolnej kultury błędu, dzięki której wszyscy poczujemy się współodpowiedzialni nie tylko za edukację, ale za kształt państwa, w którym funkcjonujemy w różnych rolach.

\section{Bibliografia}

Berger P.L., Zaproszenie do socjologii, PWN, Warszawa 1995.

Borowska T., Pedagogia ograniczeń ludzkiej egzystencji, IBE, Warszawa 2003.

Czerepaniak-Walczak M., Kultura szkoły - o jej złożoności i wielowymiarowości, „Pedagogika Społeczna”, nr 3(57)/2015.

Dernowska U., Tłuściak-Deliowska A., Kultura szkoły. Studium teoretyczno-empiryczne, Oficyna Wydawnicza Impuls, Kraków 2015.

Domagała-Kręcioch A., Majerek B., Czego (nie)uczy szkoła?, „E-mentor”, nr 1(53)/2014, http://www.e-mentor.edu.pl/artykul/index/numer/53/id/1080 (dostęp: 20.11.2018).

${ }^{37}$ M. Montessori, The Absorbent Mind, Wilder Publications, Jersey City 2008, s. 165.

${ }^{38}$ L. Sałaciński, Obowiązek, odpowiedzialność... 
Dominicé P., Uczyć się z życia. Biografia edukacyjna w edukacji dorosłych, Wydawnictwo Wyższej Szkoły Humanistyczno-Ekonomicznej, Łódź 2006.

Izdebski R., Brzyski B., Powierzyć dziecko światu, https://klubjagiellonski. pl/2016/07/15/izdebski-powierzyc-dziecko-swiatu/ (dostęp: 17.12.2019).

Jabłoński A., Krytycyzm Poppera jako podstawa socjologicznych badań cywilizacyjnego rozwoju społeczeństw, „Uniwersyteckie Czasopismo Socjologiczne”, nr 10(1)/2015, http://cejsh.icm.edu.pl/cejsh/element/bwmeta1.element.desklight-fc6a6ad2-929d-45a1-a889-df145c052084 (dostęp: 5.01.2019).

Jarkowiec M., Na górze naczelnik dyrektor, pod nim klawisze-nauczyciele, na dole więźniowie-uczniowie. Sto lat polskiej szkoły. Wyborcza.pl. Dodatek świąteczny, http://wyborcza.pl/magazyn/7,124059,24144426,na-gorze-naczelnik-dyrektor-pod-nim-klawisze-nauczyciele-na.html (dostęp: 10.12.2018).

Jaworska E., Uczenie się na błędach - wybrane zagadnienia, „Folia Pomeranae Universitatis Technologiae Stetinensis, Oeconomica”, nr 311(75)2/2014.

Keith N., Frese M., Enhancing firm performance and innovativeness trough error management culture, [w:] N.M. Ashkanasy, C.P.M. Wilderom, M.F. Peterson (red.), Handbook of organizational culture and climate, Thousand Oaks, CA, Sage Publications, London 2011.

Krzychała S., Zamorska B., Zamknięte i otwarte zmiany kultury szkoły, [w:] B.D. Gołębniak, H. Kwiatkowska (red.), Nauczyciele. Programowe (nie)przygotowanie, WNDSW, Wrocław 2012.

Kwieciński Z., Długotrwałe ślady szkolnego dzieciństwa, [w:] R. Piwowarski (red.), Dziecko. Sukcesy i porażki, IBE, Warszawa 2007.

Majewska H., Kim uczyniła mnie szkoła?, [w:] D. Klus-Stańska (red.), Dokąd zmierza polska szkoła?, Wydawnictwo Żak, Warszawa 2008.

Malewski M., Teorie andragogiczne. Metodologia teoretyczności dyscypliny naukowej, Wydawnictwo Uniwersytetu Wrocławskiego, Wrocław 2001.

Melosik Z., Postmodernistyczne kontrowersje wokół edukacji, Wydawnictwo Edytor, Poznań-Toruń 1995.

Montessori M., The Absorbent Mind, Wilder Publications, Jersey City 2008.

Oser F., Spychiger M., Lernen ist schmerzhaft. Zur Theorie des negativen Wissens und zur Praxis der Fehlerkultur [Learning is painful. On the theory of negative knowledge and the practice of error culture], Weinheim, Beltz 2005.

Polak K., Kultura szkoły. Od relacji społecznych do języka uczniowskiego, Wydawnictwo Uniwersytetu Jagiellońskiego, Kraków 2007.

Pomoc online dzieciom $w$ trudnych sytuacjach życiowych. Specyfika problemów zgłaszanych przez dzieci, Fundacja Dzieci Niczyje, Warszawa 2015, http://fdds. pl/wp-content/uploads/2016/05/Zurkowska_Pomoc_online_dzieciom_w trudnych_sytuacjach_zyciowych.pdf (dostęp: 12.02.2019).

Rotry R., Edukacja i wyzwanie ponowoczesności, [w:] Z. Kwieciński, L. Witkowski (red.), Spory o edukację. Dylematy i kontrowersje we współczesnych pedagogiach, IBE, Warszawa 1993. 
Sałaciński L., Obowiązek, odpowiedzialność oraz powinność aksjologiczna nauczyciela, [w:] L. Sałaciński, W. Theim (red.), Szanse na sukces w szkole. Nauczyciel wobec nowych wymagań, Uniwersytet Zielonogórski, Zielona Góra 2003.

Sałaciński L., Wstęp, [w:] L. Sałaciński, W. Theim (red.), Szanse na sukces w szkole. Nauczyciel wobec nowych wymagań, Uniwersytet Zielonogórski, Zielona Góra 2003.

Schulz R., Szkoła - instytucja - system - rozwój, PWN, Toruń 1992.

Taka szkoła nie jest nam potrzebna, https://www.newsweek.pl/polska/co-trzeba-zmie nic-w-polskiej-szkole-jak-reformowac-edukacje/51hs06t (dostęp: 4.03.2019).

Trompenaars F., Hampden-Turner Ch., Siedem wymiarów kultury: znaczenie różnic kulturowych w działalności gospodarczej, Oficyna Ekonomiczna, Kraków 2002.

\section{Reflections on a school's mistake culture}

Abstract: The modern world is subordinated to the struggle for success, the road to which leads through many mistakes and failures. A very important element of a school's work is to shape such competences that will allow students to function properly in a changing, uncertain and unpredictable reality. The aim of this article is to show the need to build a school's mistake culture, in order to ease young people into adulthood. The text identifies the conditions necessary to create a school error culture and discusses, on the basis of research conducted among young adults, three basic issues related to it, i.e.: the role of school in building it, attitudes towards mistakes and the reactions of teachers and learners to them

Keywords: school mistake culture, school, educational experiences, mature student

About the author: Agnieszka Domagała-Kręcioch - pedagogue, sociotherapist. Her academic interests focus on schools and the changes taking place therein. She researches the importance of educational experiences for the social functioning of adults. 


\title{
Dobrobyt materialny rodziny a marzenia dzieci w kontekście dobrostanu psychicznego
}

DOI: 10.25312/2083-2923.15/2019_08mkks

\begin{abstract}
Streszczenie: Dobrobyt materialny rodziny stanowi jeden z aspektów związanych z pojęciem szeroko rozumianego dobrostanu życiowego, w tym psychicznego. Ostatnio w literaturze przedmiotu często sygnalizuje się problem dzieciństwa w kryzysie, przywołując określenia: „dzieciństwo nadmiaru”, „dzieciństwo cukierkowe”, „pokolenie przesytu”. Aspekt ten zainspirował autorki niniejszego artykułu do sprawdzenia empirycznego, o czym marzą dzieci wychowywane w rodzinach o wysokim statusie ekonomicznym, których potrzeby materialne zaspokajane są ponad miarę. Prezentowane $\mathrm{w}$ artykule badania realizowane były w konwencji badań jakościowych z zastosowaniem metody wywiadu wśród uczniów szóstych klas renomowanych prywatnych i społecznych szkół podstawowych w Łodzi.
\end{abstract}

Słowa kluczowe: marzenia dzieci, dobrobyt materialny, dobrostan psychiczny

\footnotetext{
* Małgorzata Kierzkowska - doktor nauk społecznych w dyscyplinie pedagogika, pedagog opiekuńczo-wychowawczy, absolwentka Uniwersytetu Łódzkiego. Adiunkt w Katedrze Pedagogiki Małego Dziecka Akademii Pedagogiki Specjalnej im. Marii Grzegorzewskiej w Warszawie. Jej zainteresowania naukowe koncentrują się wokół: sytuacji dziecka we współczesnej rodzinie, problemów współczesnej rodziny, jej przemian, dysfunkcyjności, a także kierunków i form wsparcia.

** Karolina Skarbek - doktor nauk społecznych w dyscyplinie pedagogika, psycholog, absolwentka Uniwersytetu Warszawskiego. Adiunkt w Katedrze Pedagogiki Małego Dziecka Akademii Pedagogiki Specjalnej im. Marii Grzegorzewskiej w Warszawie. Prowadzi badania naukowe w zakresie uzdolnień matematycznych dzieci, prawidłowości procesu uczenia się, diagnozy dziecka. Ponadto pracuje jako psycholog w poradni psychologiczno-pedagogicznej, gdzie zajmuje się diagnozą i terapią dzieci, a także wspieraniem rodziców i nauczycieli.
} 


\section{Wprowadzenie}

Dziecięce marzenia stanowią imperatyw działania i stymulowania przyszłości. Pomagają odpowiedzieć na pytanie: kim, gdzie, jaki mogę być? „Marzenia kreują świat realistyczny, stanowią antycypację celów, planów, działań mogących przełożyć się na realne, przyszłe poczynania" ${ }^{1}$.

Planując badania dotyczące marzeń, nie miałyśmy zamiaru zgłębiać ich w kontekście dobrostanu psychicznego, ale uzyskane wyniki po dogłębnej analizie pokazały, że osoby badane, mówiąc o swoich marzeniach, wprost odwoływały się do swojego dobrostanu psychicznego. Nie zadawałyśmy dzieciom bezpośrednio pytań dotyczących ich zadowolenia z życia, nie korzystałyśmy z narzędzi do pomiaru szczęścia, afektu czy zadowolenia z życia. Jasno chcemy zatem podkreślić, że nie badałyśmy dobrostanu psychicznego jako takiego, ale uznałyśmy, że warto byłoby ukazać marzenia dziecięce w jego kontekście. Artykuł ma na celu prezentację wyników badań dotyczących dziecięcych marzeń, zanim jednak to uczynimy, chciałybyśmy wprowadzić czytelnika w ramy pojęciowe kluczowych konstruktów stanowiących podbudowę teoretyczną naszych badań.

\section{Dobrostan psychiczny a marzenia - ramy pojęciowe}

Według klasycznej definicji, „dobrostan psychiczny określa się [...] jako poznawczą i emocjonalną ocenę własnego życia. Ocena ta obejmuje zarówno emocjonalne reakcje na zdarzenia, jak i poznawcze sądy dotyczące zadowolenia i spełnienia. Tak więc dobrostan psychiczny jest pojęciem szerokim, obejmującym doświadczenie przyjemnych emocji, niski poziom negatywnych nastrojów i wysoki poziom zadowolenia z życia"2.

Nieco inaczej na dobrostan psychiczny możemy spojrzeć w kontekście dzieci. W literaturze przedmiotu ${ }^{3}$ wskazuje się trzy wymiary dziecięcego dobrostanu psychicznego - fizyczny, społeczno-emocjonalny i poznawczy, i to one odzwierciedlają jego optymalny rozwój. Dziecko, zdobywając kompetencje w tych dziedzinach, ma możliwość osiągnięcia pełnego dobrostanu. Wszystkie te wymiary są ze sobą powiązane. Deficyt w obrębie jednego z nich może przyczynić się do osłabienia osiągnięć

${ }^{1}$ J.L. Singer, Marzenia dzienne, PWN, Warszawa 1980, za: L. Wojciechowska, N. Wall, Marzenia dzienne a subiektywny dobrostan psychiczny dzieci z domu dziecka, [w:] D. Borecka-Biernat (red.), Poszukiwanie uwarunkowań zaburzeń w zachowaniu młodzieży winterakcjach społecznych, Wydawnictwo Wałbrzyskiej Wyższej Szkoły Zarządzania i Przedsiębiorczości, Wałbrzych 2009, s. 165.

${ }^{2}$ E. Diener, R.E. Lucas, S. Oishi, Dobrostan psychiczny. Nauka o szczęściu i zadowoleniu z życia, [w:] J. Czapiński (red.), Psychologia pozytywna. Nauka o szczęściu, zdrowiu, sile i cnotach człowieka, PWN, Warszawa 2005, s. 35.

${ }^{3}$ Por. L. Wojciechowska, N. Wall, dz. cyt., s. 163-187. 
w obrębie pozostałych wymiarów, co może skutkować obniżeniem ogólnego dobrostanu dziecka.

Zaspokojenie podstawowych potrzeb - zdrowie fizyczne, właściwe odżywianie, opieka zdrowotna - są czynnikami dobrostanu fizycznego niezbędnego do harmonijnego rozwoju dwóch kolejnych, czyli poznawczego i emocjonalno-społecznego. Na dobrostan emocjonalno-społeczny składa się rozumienie i regulacja emocji, zdolność radzenia sobie ze stresorami, rozwój autonomii, zaufania, rozwój samooceny tożsamości, rozwój empatii oraz kształtowanie się pozytywnych relacji społecznych z rodziną i rówieśnikami. Są to nie tylko elementy dobrostanu, które go warunkują, ale stanowią także efekt osiągania kolejnych poziomów kompetencji rozwojowych. Kluczowa w tym procesie jest rola środowiska społecznego, w którym dziecko dorasta.

Rozwój poznawczy jest istotny dla dobrostanu dzieci, szczególnie osiągnięcia w zakresie myślenia i komunikowania oraz wykorzystywania tego w codziennym życiu. Optymalny rozwój dziecka w trzech wymienionych sferach jest ważnym źródłem pozytywnych doświadczeń i przeżyć. W tej koncepcji obiektywne wskaźniki odzwierciedlają dobrostan jednostki. Takie założenie może być jednak pułapką, ponieważ może istnieć rozbieżność pomiędzy obiektywnie i subiektywnie doświadczanym stanem rzeczy, dlatego ważne jest kierowanie bezpośrednio do dziecka pytań o jego samopoczucie psychiczne. Chciałybyśmy podkreślić, że nie zadawałyśmy dzieciom bezpośrednio takiego pytania, natomiast podczas prowadzonych rozmów one same wypowiadały się w tym zakresie, tym samym pośrednio określały swój subiektywny dobrostan psychiczny.

\section{Pojęcie i definicje marzeń}

Obecnie marzenia traktowane są jako ważna aktywność poznawcza, podczas której ma miejsce proces wyjaśniania sobie świata, ale zachodzi także proces kreowania rzeczywistości, a nawet planowania w szerszej perspektywie czasowej. Wychodząc z teorii poznawczej, jak podkreśla L. Wojciechowska, marzenia na jawie definiujemy jako: „proces przetwarzania wewnętrznego zasobu informacji, uaktywniony w warunkach dopływu określonych informacji lub w warunkach ubóstwa informacji zewnętrznych, w efekcie którego strukturalizuje się nowy układ informacji lub nowa jej jakość"

Treść marzeń może stanowić źródło informacji na temat rozumienia przez dzieci siebie i świata, aktywności twórczej, niezaspokojonych potrzeb, planów na przyszłość, sposobów radzenia sobie z przystosowaniem do otoczenia. Marzenia mogą także pełnić funkcję realizacji celów jednostki ${ }^{5}$.

\footnotetext{
4 Tamże, s. 164.

5 Tamże, s. 106-110.
} 
W średnim dzieciństwie ma miejsce przechodzenie od jawnego kreowania świata wyobrażeniowego do świata wewnętrznego, mniej dostępnego w spontanicznych zachowaniach dziecka ${ }^{6}$. W okresie wczesnego dzieciństwa marzenia dzieci dotyczą zabawek, nieco późnień ubrań, posiadania pieniędzy, natomiast potem są pragnieniami na temat konkretnych cech otaczającego świata, osiągnięć własnych, uznania społecznego. Początkowo marzenia dotyczą głównie własnej osoby, a wraz z wiekiem uwzględniana jest w nich także sytuacja innych osób. Zawsze jednak w centrum pozostaje osoba marząca, pomimo wzrostu znaczenia grupy rówieśniczej, a także decentracji. Rozwój poznawczy skutkujący większym realizmem sprawia, że u dzieci stopniowo zmniejsza się myślenie magiczne, dotyczące bezwarunkowej pewności spełniania się marzeń. Rozwój indywidualności, samokontroli, samodzielności powoduje lepsze myślenie o własnych dyspozycjach oraz możliwościach realizacji marzeń.

Odnosząc się do współczesnych badań dotyczących marzeń, warto przywołać te prowadzone przez B. Dymarę oraz L. Wojciechowską ${ }^{8}$. Obie autorki podkreślają silny związek marzeń z warunkami życia dzieci oraz ich środowiskiem domowym. Ponadto ich badania pozwoliły ustalić, że dzieci w marzeniach dążą do zaspokojenia potrzeb, pragną tego, czego brakuje im do osiągnięcia dobrostanu psychicznego ${ }^{9}$. Marzenia chłopców i dziewcząt różnią się od siebie - ta rozbieżność związana jest z odmiennością ról społecznych, jakie będą odgrywać w dorosłym życiu. Marzenia dzieci stanowią silny imperatyw dążeń do bycia lepszym, doskonalszym. Są wyrazem tęsknoty za większą mocą sprawczą potrzebną do osiągnięcia sukcesu. Wyniki tych badań wskazują, że wiedza o kształtowaniu się dziecięcych marzeń ma niebywałe znaczenie dla projektowania działalności pedagogicznej. Cytowane wyniki badań stanowiły dodatkowy impuls do zajęcia się tą problematyką.

${ }^{6}$ J. Górniewicz, Rozwój i kształtowanie wyobraźni dziecka: porady dla rodziców i nauczycieli, Wydawnictwo Naukowe Praksis-UAM, Warszawa-Toruń 1991.

7 B. Dymara, Dziecko w świecie marzeń, Oficyna Wydawnicza Impuls, Kraków 1999.

${ }^{8}$ L. Wojciechowska, Kreacje wyobrażeniowe własnej osoby i otaczajacego świata u dzieci i młodzieży. Treściowa charakterystyka marzeń na jawie u dzieci wokresie średniego dzieciństwa, [w:] L. Wojciechowska (red.), Spostrzeganie zjawisk świata społecznego przez dzieci, młodzież i młodych dorostych, Wydawnictwa Uniwersytetu Warszawskiego, Warszawa 2003.

9 Podaję za: L. Wojciechowską: „Zagadnienie dobrostanu psychicznego zostało podjęte we współczesnej psychologii i uznane za naukowy przedmiot badań wraz z pojawieniem się nowej subdyscypliny - psychologii pozytywnej. [...] Współczesna koncepcja dobrostanu, związana z eudajmonistyczną wizją człowieka, zakłada, że dobrostan jest stanem uczuć, przeżyć i doświadczeń towarzyszących działaniu jednostki zmierzającej do aktualizacji własnego potencjału oraz życia zgodnego z prawdziwym Ja. Taka aktywność życiowa daje poczucie autentycznego istnienia i pełnej ekspresji siebie, a także, działając jako stymulator indywidualnego rozwoju, generuje szereg działań na rzecz otoczenia społecznego". Zob. L. Wojciechowska, N. Wall, dz. cyt., s. 166-167. 


\section{Problem badań i procedura badawcza}

Zaprezentowane w artykule wyniki badań stanowią fragment większego projektu badawczego, który realizowany był wśród dzieci młodszych (w wieku 8-9 lat) oraz starszych (13-latków), wychowywanych w różnych środowiskach, między innymi wśród dzieci z łódzkiej dzielnicy Bałuty ${ }^{10}$, mieszkających na wsiach oraz w rodzinach zamożnych.

Odnosząc się do już opublikowanych wyników badań zrealizowanych wśród dzieci żyjących w jednej z najbiedniejszych dzielnic Łodzi - Bałutach, można stwierdzić, że ich marzenia koncentrowały się przede wszystkim na zaspokojeniu podstawowych potrzeb, wokół poprawy sytuacji w domu rodzinnym, np. „zdrowie dla rodziców”, „żeby nie było biedy w domu”, „żeby tata był dla mnie miły”. Co czwarte spośród badanych wyrażało pragnienie poprawy atmosfery życia rodzinnego. W swych wypowiedziach wskazywały na częste awantury w domu, konflikty między rodzicami, a nawet przemoc.

Ich marzenia były mocno zakotwiczone w środowisku, w którym żyją, i rzadko wychodziły poza krąg kulturowy Bałut. Wymarzonymi zawodami chłopców były między innymi: kierowca ciężarówki, mechanik itp. Dziewczynki, wzorując się na kobietach ze swojego najbliższego otoczenia, chciały zostać fryzjerkami, sprzedawczyniami.

Wśród dziecięcych marzeń znalazło się wiele odniesień do niezaspokojonych potrzeb emocjonalnych. Wskazywały na nie także te dzieci, których warunki materialne środowiska rodzinnego nauczyciele określali jako dobre i bardzo dobre, jak na środowisko ubogie.

Na podstawie wyników badań można stwierdzić, iż najbogatsze marzenia miały te dzieci, które wywodzą się z rodzin o przeciętnym statusie materialnym. Ich potrzeby podstawowe są zaspokojone, ale pozostawiono im przestrzeń do kreowania pragnień. Wśród badanych dzieci znalazło się także kilkoro, które wywodziły się z rodzin zamożnych (jak na warunki dzielnicy biedy). Ich marzenia były równie skromne, co marzenia dzieci wywodzących się z rodzin najbiedniejszych.

Wyniki badań skłoniły nas do dalszej eksploracji tematyki. Zadałyśmy sobie pytanie: czy „dzieciństwo nadmiaru”"11, „dzieciństwo cukierkowe”12, „pokolenie przesytu"13, które charakteryzuje się bardzo dobrą sytuacją materialną rodzin, możliwością zaspokojenia wszystkich potrzeb materialnych ponad miarę, pozwala na swobodny

${ }^{10}$ M. Kierzkowska, Marzenia dzieci z Bałut. Konfrontacja luksusu centrum handlowego Manufaktura z warunkami życia w najbiedniejszej dzielnicy Łodzi, „Kultura i Wychowanie”, nr 10/2015 [online].

${ }^{11}$ V. Ozimkowski, Złe wychowanie, „Newsweek Polska”, 4.11.2004, za: B. Matyjas, Dzieciństwo w kryzysie. Etiologia zjawiska, Żak, Warszawa 2008, s. 69.

${ }_{12}$ H. Palska, Bieda i dostatek. O nowych stylach życia w Polsce końca lat dziewięćdziesiątych, Wydawnictwo IFiS PAN, Warszawa 2002, za: B. Matyjas, dz. cyt.

13 B. Matyjas, dz. cyt. 
rozwój marzeń, czy też dobrobyt ten wpływa na ostateczny kształt, jaki przybierają marzenia tych dzieci? Odpowiedź na to pytanie postanowiłyśmy znaleźć, badając marzenia uczniów klas szóstych wybranych prywatnych i społecznych szkół w Łodzi.

\section{Cele i pytania badawcze}

W niniejszym badaniu nasze zainteresowania koncentrowały się wokół poznania marzeń dzieci w kontekście warunków ich środowiska rodzinnego. W kontraście do wcześniej prowadzonych badań zakwalifikowałyśmy do obecnego dzieci wywodzące się ze środowiska skrajnie różnego pod względem statusu materialnego.

Głównym celem prezentowanych badań było poznanie marzeń dzieci wychowywanych w warunkach dobrobytu materialnego. W związku z tak sformułowanym celem badawczym postawiłyśmy pytanie: o czym marzą uczniowie renomowanych społecznych i prywatnych łódzkich szkół?

\section{Procedura badawcza}

Prezentowane badania realizowane były w konwencji badań jakościowych, z zastosowaniem indukcyjnej drogi poznania ${ }^{14}$. Jak pisze B. Sławecki, badacz, decydując się na indukcyjną drogę poznania, zaczyna nie od teorii, a od eksplorowania otaczającej go rzeczywistości. Istotne jest maksymalne zbliżenie się do przedmiotu poznania, aby zaobserwować wszystko to, co kluczowe jest dla wyjaśnienia i zrozumienia zjawiska społecznego, którym się zajmuje ${ }^{15}$.

W naszych badaniach przeprowadziłyśmy wywiady z uczniami szóstych klas szkół podstawowych. Zostały one zarejestrowane, a następnie dokonano ich transkrypcji z uwzględnieniem zalecanego przez D. Silvermana ${ }^{16}$ kodu. Tak przygotowany materiał badawczy poddany został dalszej analizie, wyodrębnione zostały tzw. słowa klucze, które pomogły uporządkować wypowiedzi badanych, wyłaniając z nich cztery kategorie marzeń: b y ć, m i e ć, z m i e n i a ć, p o d r ó ż o w a ć. Następnie materiał ten przeanalizowałyśmy w kontekście środowiska rodzinnego, zainteresowań uczniów oraz ich wyników w nauce. Chciałyśmy sprawdzić, czy istnieje zależność pomiędzy warunkami, w jakich żyją i rozwijają się dzieci, a wskazywanymi przez nie marzeniami. Taki związek odnotowano w przypadku badania marzeń dzieci z rodzin ubogich, których marzenia pełniły funkcję kompensacyjną. Wobec tego chciałyśmy

14 „Indukcyjna droga poznania oznacza uzasadniania przez wnioskowanie polegające na stosowaniu między innymi obserwacji w dochodzeniu do praw oraz teorii”. Podaję za: J. Such, M. Szcześniak, Filozofia nauki, WNUAM, Poznań 2006, s. 11.

15 B. Sławecki, Znaczenie paradygmatów w badaniach jakościowych, [w:] D. Jemielniak (red.), Badania jakościowe. Podejścia i teorie, PWN, Warszawa 2012, s. 71.

16 D. Silverman, Interpretacja danych jakościowych, PWN, Warszawa 2012, s. 328. 
sprawdzić, czy istnieje związek pomiędzy dobrymi warunkami materialnymi a treścią marzeń prezentowaną przez dzieci - uczniów renomowanych łódzkich szkół. Wydaje nam się, że marzenia dzieci wywodzących się z tego środowiska będą dotyczyły realizacji takich potrzeb, jak: potrzeba akceptacji społecznej, uznania i samorealizacji.

\section{Osoby badane}

Dobór grupy badawczej był celowy. Badaniami objęci zostali uczniowie klas szóstych trzech renomowanych szkół społecznych i prywatnych w Łodzi. Głównym kryterium doboru osób badanych były warunki materialne ich rodzin. Przyjęłyśmy, że jednym ze wskaźników świadczących o dobrej kondycji materialnej rodziny jest decyzja o zapisaniu dziecka do renomowanej prywatnej lub społecznej szkoły i uiszczanie comiesięcznego wysokiego czesnego. Ponadto, aby uniknąć artefaktów w zakresie oceny zamożności rodziny, dodatkowo pozyskałyśmy informacje potwierdzające dobrą kondycję finansową w wypowiedziach samych osób badanych, a także ich nauczycieli. Pośrednio świadczą o tym także wskazywane sposoby spędzania wolnego czasu, wyjazdy wakacyjne, uprawianie drogiego hobby. Dodatkowo oceny sytuacji materialnej rodzin dokonałyśmy na podstawie wypowiedzi samych uczniów, np. „Mam dużo szczęścia, że żyję tu, a nie gdzie indziej i że mogę mieć tyle rzeczy, ile mam teraz”; „Mam dużo rzeczy i jestem z tego zadowolony [...] bo ja już wszystko mam”; „Mam wszystko, jestem szczęśliwy”; „Bardzo się cieszę z tego co mam więc nie wymagam więcej”.

Zdajemy sobie sprawę z tego, że przyjęte przez nas kryterium oceny kondycji finansowej rodzin jest niedoskonałe, ale rodzice badanych uczniów nie chcieli udzielać informacji dotyczących wysokości dochodów oraz innych wskaźników, które pozwoliłby nam dokonać obiektywnej oceny statusu materialnego rodzin. O liczbie badanych zadecydowały także takie czynniki, jak: pisemne zgody rodziców na udział dziecka w badaniu oraz oddzielne zgody na nagrywanie rozmów, zgody dzieci na udział w badaniu.

Podsumowując, ostatecznie w badaniach wzięło udział 20 uczniów: 7 chłopców i 13 dziewczynek oraz ich wychowawcy ${ }^{17}$.

\section{Metody i techniki badawcze}

W badaniach wykorzystane zostały wywiady jako najczęściej stosowana metoda w badaniach jakościowych ${ }^{18}$. Były to wywiady mieszane - w części swobodne, a w części skategoryzowane. Z jednej strony, częściowo rozmowa prowadzona była według wcześniej

${ }_{17}$ Zaskoczyła nas duża trudność w uzyskaniu zgód zarówno dyrektorów, jak i rodziców na udział dzieci w badaniach. Pomimo zapewnienia anonimowości osobom biorącym udział w badaniu oraz dokładnemu wyjaśnieniu procedury badawczej udało nam się uzyskać jedynie zgody trzech placówek.

${ }^{18}$ U. Flick, Projektowanie badania jakościowego, PWN, Warszawa 2012, s. 137. 
przygotowanych dyspozycji, zarysu scenariusza, a w części miała charakter swobodny. Pytania zadawano spontanicznie, wynikały z podążania za tokiem wypowiedzi osoby badanej. Były to wywiady jednorazowe. Po nawiązaniu kontaktu z osobą badaną i uzyskaniu jej zgody przeprowadzono wywiad twarzą w twarz. Badania przeprowadzone zostały na terenie szkoły, po obowiązkowych zajęciach dydaktycznych, w specjalnie przygotowanym pomieszczeniu, zapewniającym komfort psychiczny. Wszystkie rozmowy zostały nagrane.

Przeprowadzone zostały także wywiady swobodne z nauczycielami, które były poprzedzone uzyskaniem zgody na badania od dyrekcji szkoły, a także od rodziców każdego z dzieci, o którym chciałyśmy rozmawiać. Nauczyciele pytani byli o: osiągnięcia szkolne dzieci, stopień współpracy rodziców ze szkołą, a także o warunki materialne badanych uczniów.

\section{Wyniki badań}

Analiza transkrypcji przeprowadzonych wywiadów pozwoliła wyłonić „słowa klucze", a następnie na ich podstawie uporządkować dziecięce marzenia w kategorie: b y ć, m i e ć, z m i e n i a ć, p o d r ó ż o w a ć. Zanim jednak przejdziemy do prezentacji marzeń należących do poszczególnych kategorii, przedstawimy charakterystykę środowiska wychowawczego w kontekście warunków stworzonych przez rodziców badanych dzieci.

\section{Charakterystyka środowiska wychowawczego w kontekście dobrobytu materialnego}

Wnikliwa analiza informacji uzyskanych od wychowawców klas badanych uczniów pozwoliła nam stwierdzić, że rodzice są zaangażowani we współpracę z nauczycielami, utrzymują z nimi stały kontakt, regularnie uczestniczą w zebraniach klasowych. Wszyscy wychowawcy zgodnie podkreślali wzorową współpracę z rodzicami uczniów biorących udział w badaniach. Nauczyciele wskazywali także, że rodzice chętnie angażują się w życie szkoły, organizację uroczystości oraz akcji społecznych podejmowanych przez uczniów. Ponadto rodzice wykazują duże zainteresowanie wynikami w nauce swoich dzieci, ściśle koresponduje to z naszymi spostrzeżeniami, że dla badanych dzieci priorytetem jest nauka. Uczniowie wykazują się systematycznością, pracowitością i dużą ambicją. Ciężka praca samych badanych oraz zaangażowanie ich rodziców przynosi wymierne rezultaty - uczniowie biorą udział w różnych konkursach, zajmując w nich wysokie pozycje, uzyskują także bardzo dobre wyniki z egzaminów. Generalnie, wszyscy badani uczniowie osiągają wysokie wyniki w nauce ${ }^{19}$.

${ }_{19}$ Na podstawie nominacji nauczycieli okazało się, że 20\% badanych uczniów osiąga celujące rezultaty w nauce, $60 \%$ wyniki bardzo dobre, $10 \%$ dobre i jedynie $10 \%$ badanych uzyskuje wyniki dostateczne. 
Rodzice i nauczyciele, chcąc stymulować potencjał badanych dzieci, angażują je w zajęcia dodatkowe rozwijające ich zdolności i zainteresowania. Analiza pozalekcyjnej aktywności dzieci pokazała, że najchętniej wybierane są przez nie takie koła zainteresowań, jak: historyczne, teatralne, matematyczne, przyrodnicze i informatyczne. Dzieci uczestniczą także w różnych kursach językowych, dotyczy to: języka włoskiego, francuskiego, angielskiego. Wśród podejmowanych aktywności artystycznych najczęściej wybierane są: kurs grafiki i rysunku, zajęcia gry na gitarze, taniec, zajęcia w szkole muzycznej, zajęcia teatralne. Uczniowie poza standardowymi aktywnościami sportowymi takimi jak: basen, karate, treningi piłki ręcznej, nożnej, koszykówki, biorą udział w treningach wspinaczkowych, jazdy konnej, łucznictwa, rugby, a także zdobywają patenty żeglarskie czy przygotowują się do zawodów wyścigowych gokardami. Każde dziecko uczestniczy w kilku rodzajach kosztownych zajęć pozalekcyjnych.

\section{Analiza marzeń badanych uczniów}

Wszystkie marzenia badanych dzieci zostały podzielone na cztery kategorie: b y ć, m i e ć, z m i e n i a ć, p o d r ó ż o w a ć. Uznałyśmy, że warto byłoby przedstawić je w formie tabelarycznej. W tabeli 1 przedstawione zostały marzenia dzieci uporządkowane w kategorie. Uznałyśmy, że warto zaprezentować otrzymane wyniki z uwzględnieniem płci badanych, ponieważ widoczne są jakościowe różnice w marzeniach chłopców i dziewcząt. 


\begin{tabular}{|c|c|c|c|}
\hline \multirow{6}{*}{ 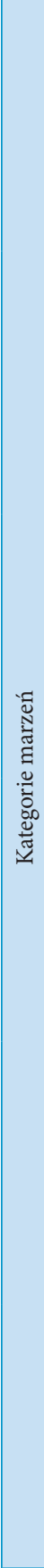 } & 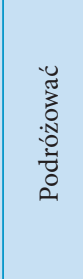 & 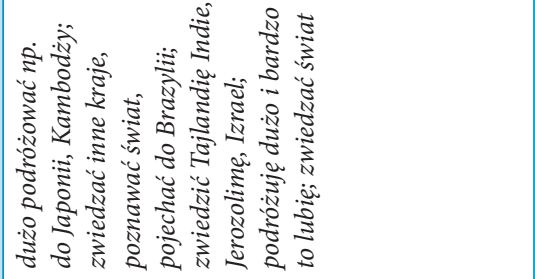 & 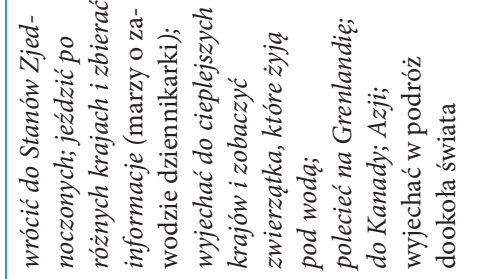 \\
\hline & \multirow{3}{*}{ 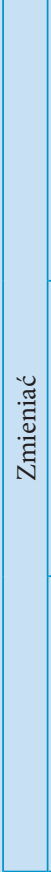 } & 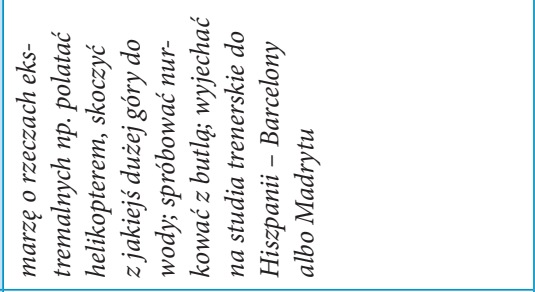 & 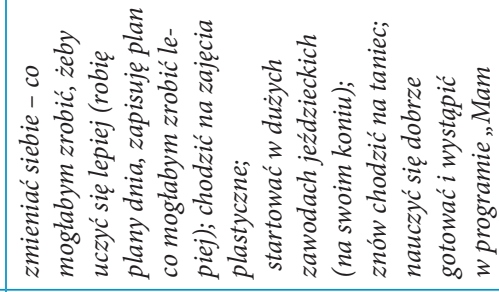 \\
\hline & & 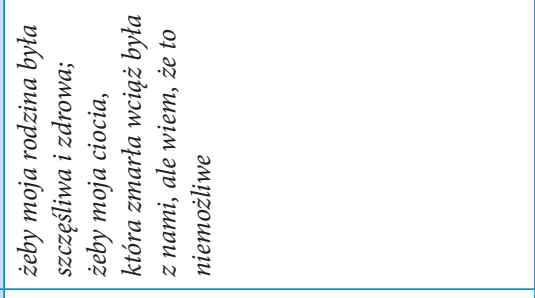 & 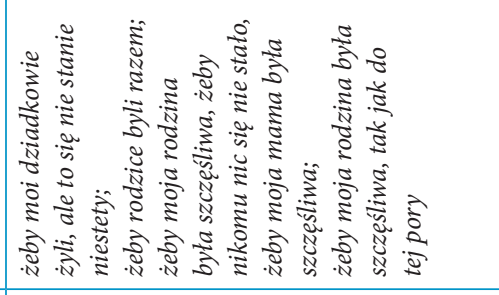 \\
\hline & & 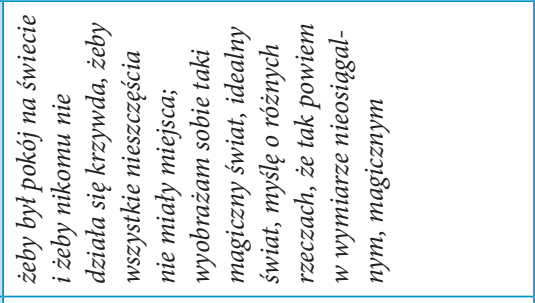 & 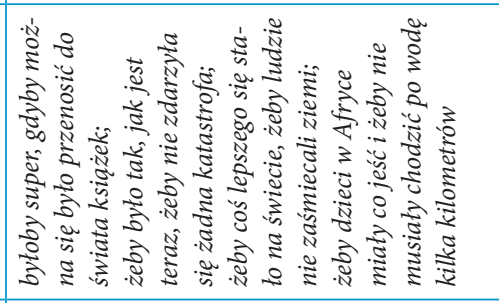 \\
\hline & $\stackrel{\mathscr{u}}{\stackrel{\nu}{\Sigma}}$ & 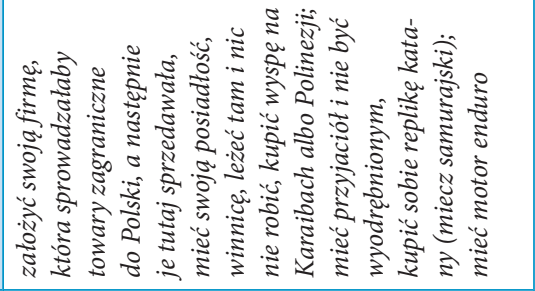 & 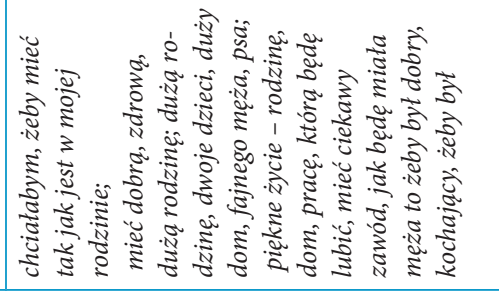 \\
\hline & 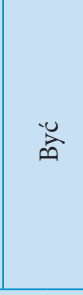 & 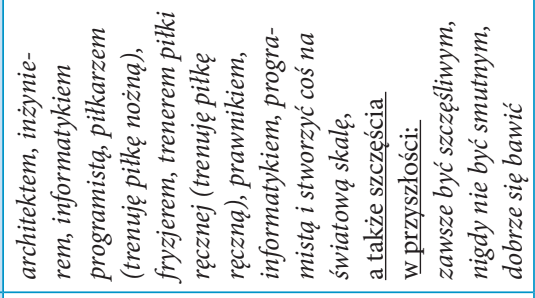 & 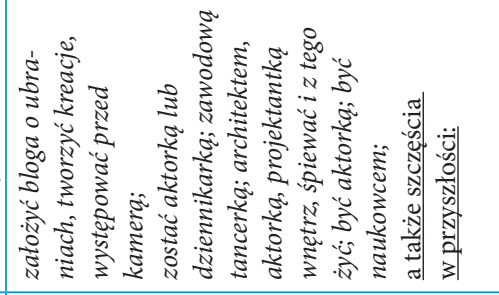 \\
\hline & $\frac{\ddot{u}}{\tilde{\pi}}$ & 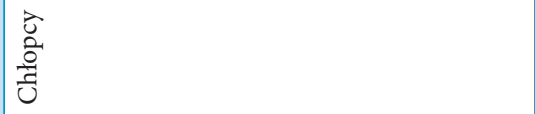 & 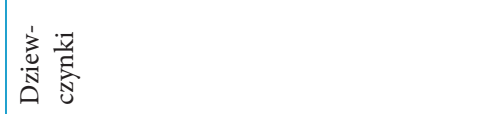 \\
\hline
\end{tabular}




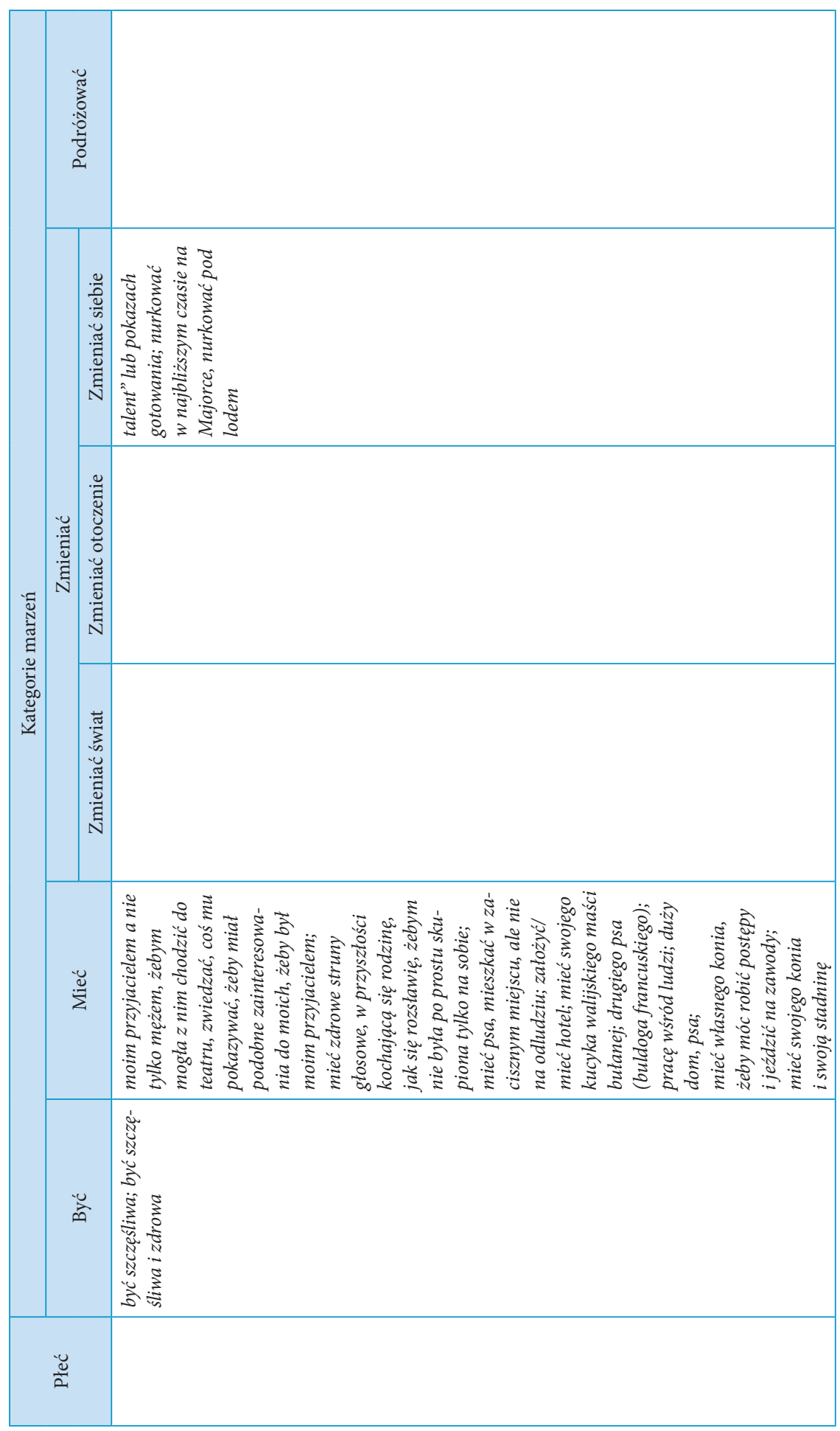


Analiza zawartości tabeli pokazuje, że kategoria marzeń „być” odnosi się do planów dotyczących wyboru przyszłego zawodu - tego, kim chcieliby zostać w przyszłości. Ponadto zawiera spontanicznie wypowiedziane deklaracje przez osoby badane o chęci bycia szczęśliwym w przyszłości. Chłopcy chcieliby zostać architektami, inżynierami, informatykami, piłkarzami czy prawnikami. Dziewczynki wybierały zawody związane z modą, występowaniem przed kamerą, ale także wyrażały chęć zostania naukowcem.

Kategoria marzeń „mieć” w przypadku chłopców koncentrowała się wokół wymiarów materialnych, a w przypadku dziewczynek wartości psychologicznych. Chłopcy chcieli mieć swoją firmę, posiadłość, wyspę, winnicę, replikę miecza samurajskiego, konkretny model motocykla. Dziewczynki deklarowały, że chciałyby mieć szczęśliwą rodzinę, piękne życie, fajnego męża, ciekawy zawód, dzieci, psa, konia.

W kategorii marzeń „zmieniać” pojawiały się trzy aspekty odnoszące się do różnych zakresów. Dlatego w jej ramach zostały wyodrębnione podkategorie: „zmieniać świat”, „zmieniać swoje otoczenie”, „zmieniać siebie”. Podkategoria marzeń „zmieniać świat" ma charakter idealistyczny z dużym komponentem altruistycznym. Chłopcy wymieniali: żeby był pokój na świecie i żeby nikomu nie działa się krzywda; żeby wszystkie nieszczęścia nie miały miejsca. Dziewczynki wskazywały m.in.: żeby dzieci w Afryce miały co jeść. Podkategoria „zmieniać swoje otoczenie” najczęściej odnosiła się do życia rodzinnego. Dzieci, wiedząc, że jest to niemożliwe, pragnęły odwrotu niektórych wydarzeń życiowych, np. ponownego scalenia rodziny, przebywania z dziadkami, ciocią, którzy już nie żyją. Spontanicznie odnosili się także do poczucia bycia szczęśliwym i permanentnego zachowania tego stanu, „żeby moja rodzina była szczęśliwa tak jak do tej pory”. Ostatnia podkategoria „zmieniać siebie” w odniesieniu do chłopców dotyczy doświadczania ekstremalnych przeżyć, sprawdzania siebie w wyjątkowo trudnych warunkach, np. latanie helikopterem, skok z dużej wysokości do wody, nurkowanie. Dziewczynki natomiast chciałyby zmieniać siebie, doskonaląc swoje umiejętności związane z uczeniem, rozwijaniem posiadanych talentów, np. uczęszczać na zajęcia plastyczne, startować w zawodach jeździeckich, uczestniczyć w konkursach tanecznych.

Ostatnia kategoria marzeń dotyczy „podróżowania” związanego z poznawaniem i zwiedzaniem świata. Tutaj zarówno chłopcy, jak i dziewczęta marzą o poznawaniu najdalszych zakątków świata, miejsc wyjątkowych i egzotycznych, np. Indii, Tajlandii, Grenlandii, Kambodży.

\section{Wnioski z badań}

Podsumowując uzyskane wyniki badań, można stwierdzić, że marzenia szóstoklasistów wychowywanych w środowisku o wysokim statusie materialnym głównie koncentrują się wokół wyboru zawodu oraz wykonywania go w przyszłości. Wymarzone zawody ściśle wiążą się z aktualnymi zainteresowaniami i realizowanym hob- 
by. Interpretując to w świetle literatury przedmiotu, należy zauważyć, że marzenia pełnią tu funkcję planów na przyszłość, określają aspiracje, a także ukazują sposób, w jaki dzieci postrzegają rzeczywistość. W wypowiedziach badani wprost odnoszą się do bardzo dobrych warunków materialnych zapewnianych im przez rodziców, dzięki czemu mają możliwość realizacji drogich pasji i nietuzinkowych zainteresowań. Zawody, do których aspirują badani uczniowie, są bardzo prestiżowe, wymagają solidnej edukacji i ukończenia elitarnych uczelni. Chłopcy mają dość dobrze sprecyzowane marzenia dotyczące wyboru przyszłego zawodu. Plany dziewczynek w tym zakresie są mniej konkretne, a wskazywane ewentualne zawody dotyczą realizacji aktualnych zainteresowań.

Na kształt ujawnianych przez dzieci marzeń z całą pewnością wpłynęło zarówno środowisko domowe, jak i szkolne. Tworzą one szeroki wachlarz możliwości realizacji zainteresowań w ramach urozmaiconych i wyszukanych zajęć dodatkowych, kół zainteresowań. Środowisko edukacyjne stworzone w płatnych, prestiżowych szkołach silnie rozbudza aspiracje, uczy konsekwentnego dążenia do wyznaczanych celów, a także premiuje systematyczność.

Zaprezentowane w poszczególnych kategoriach marzenia badanych dzieci są ściśle powiązane z realizacją potrzeb wyższego rzędu. Dzieci wychowywane w środowisku dobrobytu materialnego nie wyrażają wprost marzeń związanych z posiadaniem pieniędzy. Na plan pierwszy wysuwają się te dotyczące zawodów związanych z zainteresowaniami, a drogie hobby wyrażają pośrednio potrzebę utrzymania wysokiego statusu materialnego. Dzieci wskazują na takie pasje, które są charakterystyczne dla rodzin żyjących w dobrobycie materialnym. Wychowywanie dzieci w takich warunkach implikuje ich chęć podróżowania, poznawania różnych zakątków świata. Podróże, o jakich marzą badani, wypływają z ciekawości poznawczej, ale zarazem odbiegają od standardów przejawianych przez ich rówieśników posiadających inny status materialny; destynacje podróżnicze często są nietuzinkowe, związane z odległymi krajami. Wysoki status materialny ujawnia się w przywoływanych marzeniach, choć nie bezpośrednio. Trzeba jednak podkreślić, że dla badanych dzieci bardzo ważne są też wartości niematerialne związane ze szczęściem własnej rodziny, a także altruistyczne i idealistyczne pobudki mające chęć zapewnienia szczęścia i dobrobytu innym ludziom i dzieciom na terenach objętych wojną, głodem i barkiem wody. Pojawiły się też marzenia związane ze świadomością ekologiczną, w których to dbałość o środowisko postrzegana jest jako dobro ogólnoludzkie. Tak jak jasno określiłyśmy to we wprowadzeniu do niniejszego artykułu, nie badałyśmy dobrostanu psychicznego, natomiast niemal wszystkie dzieci badane spontanicznie deklarowały odczuwane poczucie szczęścia, doceniały znakomite warunki materialne zapewnione im przez rodziców. To poczucie subiektywnego dobrostanu psychicznego związane ze szczęściem implikuje chęć zapewnienia podobnych warunków swoim najbliższym w przyszłości. Mimo że badane dzieci dostrzegają swoją dobrą sytuacją materialną, korzystają ze stworzonych im możliwości samorealizacji, analizując ich marzenia, trudno je 
scharakteryzować jako „pokolenie nadmiaru”, które w wizji nakreślonej przez B. Matyjas ,jak automaty powtarzają chcę to mieć, [...] które jeśli dostaną to czego tak bardzo pragną, nie czują się usatysfakcjonowani i wkrótce mają nowe żądania. Jeszcze, jeszcze, jeszcze. Wciąż więcej i więcej. Bez opamiętania, bez hamulców"20.

\section{Bibliografia}

Diener E., Lucas R.E., Oishi S., Dobrostan psychiczny. Nauka o szczęściu i zadowoleniu z życia, [w:] J. Czapiński (red.), Psychologia pozytywna. Nauka o szczęściu, zdrowiu, sile i cnotach człowieka, PWN, Warszawa 2005.

Dymara B., Dziecko w świecie marzeń, Oficyna Wydawnicza Impuls, Kraków 1999.

Flick U., Projektowanie badania jakościowego, PWN, Warszawa 2012.

Górniewicz J., Rozwój i kształtowanie wyobraźni dziecka: porady dla rodziców i nauczycieli, Wydawnictwo Naukowe Praksis-UAM, Warszawa-Toruń 1991.

Matyjas B., Dzieciństwo w kryzysie. Etiologia zjawiska, Żak, Warszawa 2008.

Ozimkowska V., Złe wychowanie, „Newsweek Polska”, 4.11.2004.

Palska H., Bieda i dostatek. O nowych stylach życia $w$ Polsce końca lat dziewięćdziesiatych, Wydawnictwo IFiS PAN, Warszawa 2002.

Silverman D., Interpretacja danych jakościowych, PWN, Warszawa 2012.

Singer J.L., Marzenia dzienne, PWN, Warszawa 1980.

Sławecki B., Znaczenie paradygmatów w badaniach jakościowych, [w:] D. Jemielniak (red.), Badania jakościowe. Podejścia i teorie, PWN, Warszawa 2012.

Such J., Szcześniak M., Filozofia nauki, WNUAM, Poznań 2006.

Wojciechowska L., Kreacje wyobrażeniowe własnej osoby i otaczającego świata u dzieci i młodzieży. Treściowa charakterystyka marzeń na jawie u dzieci w okresie średniego dzieciństwa, [w:] L. Wojciechowska (red.), Spostrzeganie zjawisk świata społecznego przez dzieci, młodzież i młodych dorosłych, Wydawnictwa Uniwersytetu Warszawskiego, Warszawa 2003.

Wojciechowska L., Wall N., Marzenia dzienne a subiektywny dobrostan psychiczny dzieci z domu dziecka, [w:] D. Borecka-Biernat (red.), Poszukiwanie uwarunkowań zaburzeń w zachowaniu młodzieży winterakcjach społecznych, Wydawnictwo Wałbrzyskiej Wyższej Szkoły Zarządzania i Przedsiębiorczości, Wałbrzych 2009.

${ }^{20}$ B. Matyjas, dz. cyt., s. 69. 
Family material well-being and children's dreams in the context of psychological well-being

Abstract: The material well-being of the family is one of the aspects related to the concept of broadly understood holistic well-being, including psychological well-being. In the literature, the problem of childhood in crisis is often signalled under these terms: childhood of excess, candy childhood, generation of satiety. This inspired the authors of this article to check empirically what children who are raised in families of high economic status and whose material needs are satisfied excessively, dream of (wish for). The research presented in the article was carried out in the convention of qualitative research, using the interview method, among sixth grade students of private and public primary schools in Lodz.

Keywords: children's dreams, material well-being, psychological well-being

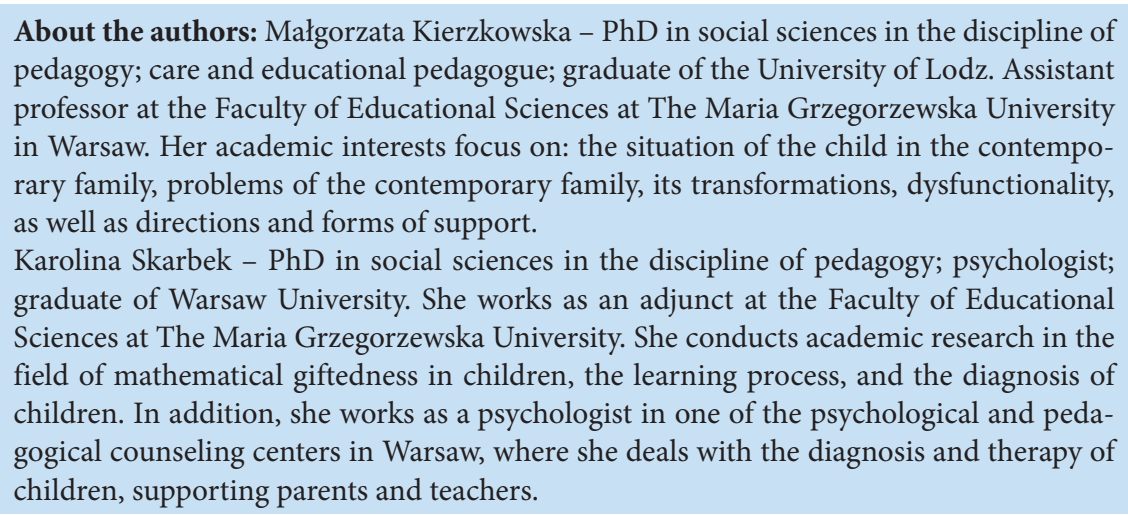




\title{
Specjalne potrzeby edukacyjne uczniów z rdzeniowym zanikiem mięśni (SMA)
}

DOI: 10.25312/2083-2923.15/2019_06kg

\begin{abstract}
Streszczenie: Edukacja włączająca wymaga od wszystkich nauczycieli zapoznawania się z różnymi niepełnosprawnościami, z którymi mogą się zetknąć w swojej praktyce zawodowej. Celem niniejszego artykułu jest przybliżenie pedagogom obrazu uczniów ze specyficzną chorobą neurodegeneracyjną, jaką jest rdzeniowy zanik mięśni (SMA). Choroba ta powoduje niepełnosprawność ruchową, ale sprawność intelektualna zostaje zachowana, zatem przed nauczycielami - głównie w szkołach ogólnodostępnych, bo tam najczęściej uczą się tacy uczniowie - stoi wyzwanie związane ze stworzeniem warunków do zaspokojenia ich specjalnych potrzeb edukacyjnych i umożliwienia samorealizacji, mimo nasilających się ograniczeń. W artykule przedstawiono charakterystykę SMA i największe zagrożenia w przebiegu tej choroby oraz ich skutki. Omówiono funkcjonalne ograniczenia, które mogą rzutować na możliwości uczenia się. Dalsza część artykułu ukazuje specyfikę specjalnych potrzeb edukacyjnych i możliwości wsparcia ucznia z SMA dotyczące m.in. dostosowania organizacji nauczania, metod nauczania i środków dydaktycznych.
\end{abstract}

Słowa kluczowe: rdzeniowy zanik mięśni, SMA, edukacja, uczeń, specjalne potrzeby edukacyjne, edukacja włączająca

\section{Wprowadzenie}

Rdzeniowy zanik mięśni (ang. Spinal Muscular Atrophy - SMA), jako jedna z chorób neurodegeneracyjnych nerwowo-mięśniowych, zawsze był problemem zagrażającym życiu chorych i stopniowo obniżającym jego jakość, jednak zrobiło się w Polsce o nim głośniej w 2016 roku, gdy uczniowie Gimnazjum nr 2 w Koninie napisali list do premier Beaty Szydło, kierowani chęcią pomocy swemu koledze Antkowi, chorującemu na tę chorobę. Ten pozornie jedynie publicystyczny fakt, nie tylko na chwilę zwró-

" Karolina Gniazdowska - doktorantka UKW na kierunku pedagogika; zainteresowania naukowe: edukacja włączająca, Konwencja o prawach osób niepełnosprawnych, wykluczenie społeczne kobiet z niepełnosprawnościami, seksualność kobiet z niepełnosprawnościami. 
cił uwagę społeczeństwa na SMA jako chorobę, ale także na sytuację ucznia z SMA w szkole i w zespole uczniowskim, wśród rówieśników ${ }^{1}$. Najczęściej dostrzegany był bowiem jedynie problem ograniczeń ruchowych, bez pozostałych właściwości tej choroby, w tym czynnika psychologicznego, związanego z utratą sprawności i perspektywą jej dalszych ograniczeń w miarę postępu choroby. Ze względu na wielość typów SMA - z czego rzadko zdaje sobie sprawę społeczeństwo, w tym nawet nauczyciele pracujący z takimi uczniami - jak również z powodu nieodróżniania SMA od innych chorób powodujących dysfunkcje ruchowe (np. od mózgowego porażenia dziecięcego czy stanów porażennych pourazowych) łatwo o powierzchowność wiedzy o wynikających stąd potrzebach rozwojowych i edukacyjnych, co sprzyja tworzeniu się niekorzystnych stereotypów i mitów. Dotyczą one np. oceny możliwości intelektualnych uczniów z SMA lub przekonań o krótkiej perspektywie przeżycia. Tymczasem jest to grupa uczniów o dużych zasobach, które można i trzeba rozwijać w procesie kształcenia, i to z uwzględnieniem dłuższej perspektywy czasowej, gdyż większość chorych z SMA ma przed sobą na szczęście wiele lat życia, a postęp medyczny sprzyja jego stałemu wydłużaniu. Dlatego warto przybliżyć - zarówno pedagogom specjalnym, jak i innym nauczycielom realizującym kształcenie integracyjne lub edukację włączającą - charakterystykę specjalnych potrzeb edukacyjnych wynikających z tej choroby.

Dzieci i młodzież z SMA spełniają podwójne kryterium specjalnych potrzeb edukacyjnych: jako uczniowie z przewlekłą chorobą i jako uczniowie z niepełnosprawnością ${ }^{2}$ W obu przypadkach system oświaty zobowiązany jest udzielić pomocy psychologiczno-pedagogicznej, przewidzianej dla wszystkich uczniów z długiej listy wymienionych w rozporządzeniu ministerialnym specjalnych potrzeb edukacyjnych ${ }^{3}$, jednak niepełnosprawność (ściślej: niepełnosprawność ruchowa) jest też sytuacją podmiotową ucznia, w której system oświaty przewiduje wydanie orzeczenia o potrzebie kształcenia specjalnego oraz objęcie go takim kształceniem ${ }^{4}$. Warto zaznaczyć, że kształcenie specjalne nie oznacza obecnie kształcenia w szkole specjalnej - zresztą uczniowie z SMA, o ile nie pojawiały się dodatkowo inne niepełnosprawności, raczej do takich szkół nie trafiali. Kształcenie specjalne to także nauka w szkole/klasie integracyjnej, a od kilku lat także edukacja włączająca w każdej innej szkole ogólnodo-

${ }^{1}$ B. Pieczyńska, Uczniowie z Konina napisali list do premier Szydło w sprawie SMA, „Głos Wielkopolski”, 30.10.2016, http://www.gloswielkopolski.pl/wiadomosci/konin/a/uczniowie-z-konina-napisali-list-do-premier-szydlo-w-sprawie-sma,11202684/ (dostęp: 14.07.2018).

2 Rozporządzenie Ministra Edukacji Narodowej z dnia 9 sierpnia 2017 r. w sprawie zasad udzielania i organizacji pomocy psychologiczno-pedagogicznej w publicznych przedszkolach, szkołach i placówkach (Dz. U. z 2017 r. poz. 1591); Rozporządzenie Ministra Edukacji Narodowej z dnia 7 września 2017 r. w sprawie orzeczeń i opinii wydawanych przez zespoły orzekające działające w publicznych poradniach psychologiczno-pedagogicznych (Dz.U. z 2017 r. poz. 1743).

3 Tamże.

${ }^{4}$ Rozporządzenie Ministra Edukacji Narodowej z dnia 9 sierpnia 2017 r. w sprawie warunków organizowania kształcenia, wychowania i opieki dla dzieci i młodzieży niepełnosprawnych, niedostosowanych społecznie i zagrożonych niedostosowaniem społecznym (Dz.U. z 2017 r. poz. 1578). 
stępnej. O specjalnym charakterze decyduje to, w jaki sposób szkoła wybrana przez rodzica wypełnia zalecenia poradni psychologiczno-pedagogicznej, zawarte w orzeczeniu o potrzebie kształcenia specjalnego.

Ze względu na zachowaną sprawność intelektualną należy przyjąć, że klasa integracyjna i edukacja włączająca to najczęstsze i najkorzystniejsze ścieżki edukacyjne dla uczniów z SMA ${ }^{5}$ - o ile właściwie zostaną rozpoznane i zaspokojone ich specyficzne potrzeby. Jednocześnie niezależnie od wyboru rodzaju szkoły uczniowie z SMA często korzystają także z możliwości realizacji nauki we własnym domu, w formie zajęć indywidualnych z dojeżdżającym nauczycielem lub nauczycielami. Należy jednak zauważyć, że nauczanie indywidualne powinno być ostatecznościąa: powinno się je stosować tylko wtedy, kiedy uczeń nie jest w stanie uczęszczać do szkoły z uwagi na stan zdrowia, co nie jest równoznaczne z niepełnosprawnością ruchową. Nauka w szkole przynosi wiele korzyści. Dla prawidłowego rozwoju bardzo istotne są relacje międzyludzkie. Dlatego należy zrobić wszystko, by uczeń z SMA mógł w pełni korzystać z możliwości, jakie daje inkluzja. Jednym z warunków tego jest właściwe rozpoznanie jego potrzeb.

\section{Charakterystyka SMA i wynikających z niego ograniczeń funkcjonalnych}

Rdzeniowy zanik mięśni jest chorobą o podłożu genetycznym. Jak już wspomniano, znajduje się w grupie chorób nerwowo-mięśniowych. Pojawia się w wyniku niedoboru białka SMN (ang. Survival of Motor Neuron) w komórkach nerwowych. Białko to warunkuje przeżycie neuronów ruchowych, jest potrzebne do prawidłowego funkcjonowania neuronów motorycznych, które są odpowiedzialne za poruszanie mięśniami szkieletowymi. Ponadto istnieją przypuszczenia, iż białko SMN może wywierać bezpośredni wpływ na komórki mięśniowe. Co istotne, im więcej białka SMN, tym łagodniejszy przebieg SMA. Niestety, nie jest możliwe dostarczenie białka z zewnątrz, powstaje ono w procesach wewnątrzkomórkowych. Niedobór białka jest rezultatem mutacji - zmiany w kodzie genetycznym na piątym chromosomie w głównym genie (o symbolu SMN1). Gen ten koduje (produkuje) białko SMN7.

Rdzeniowy zanik mięśni występuje na całym świecie i z częstością 1 na 600010000 urodzeń w ciągu roku'. W Polsce nosicielstwo genu warunkującego wystąpie-

${ }^{5}$ Zob. przypis 1 .

${ }^{6}$ B. Jachimczak, Dydaktyczne i pozadydaktyczne uwarunkowania efektów nauczania indywidualnego dzieci przewlekle chorych, Oficyna Wydawnicza Impuls, Kraków 2011.

7 A. Łusakowska (red.), Rdzeniowy zanik mięśni (SMA) - podstawowe informacje, Fundacja SMA, Warszawa 2016, s. 8.

${ }^{8}$ Ch. Mastella, G. Ottonello (red.), Z SMA1 na co dzień - Vademecum opieki nad dzieckiem z najcięższa postacią rdzeniowego zaniku mięśni, Fundacja SMA, Warszawa 2016, s. 42. 
nie tej choroby wynosi 1 na 35 osób, co daje częstotliwość występowania SMA 1 na poziomie $4900^{9}$.

Rozwój choroby jest zazwyczaj powiązany z czasem wystąpienia pierwszych objawów, które uwarunkowane są ilością białka SMN powstającego w neuronach. Rdzeniowy zanik mięśni jest chorobą, którą cechuje duże zróżnicowanie w odniesieniu do wieku, w którym obserwuje się pierwsze symptomy, oraz tempa osłabienia mięśni, a w konsekwencji ich zaniku. Z reguły rdzeniowy zanik mięśni jest chorobą postępującą ${ }^{10}$ i nie wiąże się tylko z ograniczeniami lokomocyjnymi. Do największych zagrożeń w SMA zalicza się: osłabienie mięśni oddechowych, mięśni gardła i przełyku oraz mięśni tułowia i postępujące skrzywienie kręgosłupa ${ }^{11}$. Zwiększona podatność na infekcje dróg oddechowych sprawia, że uczniowie mogą opuszczać wiele dni w szkole. Osłabienie mięśni gardła i przełyku powoduje krztuszenie się, dławienie się napojami, pokarmem lub śliną. Wielogodzinne siedzenie powoduje dyskomfort i ból pleców. Brak możliwości odpoczynku, położenia się może skutkować szybkim męczeniem się i problemami z koncentracją podczas zajęć.

Pierwszym na świecie zarejestrowanym lekiem na rdzeniowy zanik mięśni jest Nusinersen (nazwa handlowa: Spinraza), który został dopuszczony do leczenia w Stanach Zjednoczonych 24 grudnia 2016 roku, natomiast na obszarze Unii Europejskiej 30 maja 2017 roku $^{12}$. To przełomowe odkrycie i szansa na inne, lepsze życie. Niestety, koszty leczenia są bardzo wysokie. Polska była jednym z ostatnich krajów w Unii Europejskiej, w których leczenie SMA nie było refundowane. Niemowlęta z SMA umierały, dzieci i dorośli tracili resztki swoich sił. Obecnie sytuacja się zmienia, lek wprowadzany jest w naszym kraju.

W międzynarodowej literaturze wyróżnia się kilka typów SMA:

- SMA 1 - objawy pojawiają się we wczesnym niemowlęctwie, czasem już w okresie prenatalnym, jest to zarówno najcięższa, jak i najczęściej występująca postać (ok. $45 \%$ chorych na SMA posiada typ 1);

- SMA 2 - objawy pojawią się w okresie późnoniemowlęcym (ok. 20\% chorych);

- SMA 3 - objawy pojawiają się w okresie dziecięcym i młodzieńczym (ok. 30\% chorych);

- SMA 4 - objawy pojawiają się w dorosłości, a przebieg choroby jest najłagodniejszy ${ }^{13}$.

SMA, zwłaszcza typu 3 i 4, mimo niepełnosprawności ruchowej, nie oznacza gorszego rozwoju intelektualnego, pozwala na rozwijanie swoich pasji i spełnianie się w życiu. Osoby dotknięte SMA chętnie pogłębiają swoje zainteresowania i często

${ }^{9} \mathrm{~J}$. Borkowska i in., Incidence of spinal muscular atrophy in Poland - more frequent than predicted?, „Neuroepidemiology”, nr 34/2010, s. 152-157.

10 A. Łusakowska (red.), dz. cyt., s. 9.

11 Tamże, s. 19.

12 Nusinersen, https://www.fsma.pl/leki/nusinersen/ (dostęp: 5.07.2018).

${ }^{13}$ A. Łusakowska (red.), dz. cyt., s. 11. 
osiągają imponujące sukcesy naukowe (np. zmarły niedawno wybitny fizyk teoretyczny Steve Hawking ${ }^{14}$ ), przy czym należy zaznaczyć, że część z nich twierdzi, iż gdyby nie doświadczyli SMA, być może brakowałoby im motywacji i nie przykładaliby takiej wagi do nauki. W celu potwierdzenia tych słów można przytoczyć fragment artykułu Z piekła do nieba: „Chorzy na SMA to często osoby bardzo inteligentne - mówi prof. Katarzyna Kotulska-Jóźwiak z Kliniki Neurologii i Epileptologii Instytutu »Pomnik-Centrum Zdrowia Dziecka«. - W SMA oszczędzone są funkcje wyższe układu nerwowego - to choroba, w której rozwój psychiczny i intelektualny jest prawidłowy, a często nawet powyżej normy. [...] Dziecko z rdzeniowym zanikiem mięśni to zwykle najlepszy uczeń w szkole, który wygrywa olimpiady przedmiotowe [...]"15.

\section{Specyfika specjalnych potrzeb edukacyjnych i możliwości pomocy uczniowi z SMA}

Zgodnie z Konwencją o prawach osób niepełnosprawnych osoby te mają prawo do nauki, rozwijania swoich zdolności i umiejętności, bez dyskryminacji i na zasadzie równych szans. Państwa zobowiązały się do dopilnowania, by osoby niepełnosprawne mogły uczęszczać do szkół i kontynuować naukę w wieku dorosłym, jeśli wyrażają taką chęć. Ponadto państwa mają zapewnić odpowiednie wsparcie w nauce z uwzględnieniem indywidualnych potrzeb osób niepełnosprawnych ${ }^{16}$.

W obowiązku gminy leży zapewnienie właściwych warunków do nauki dla wszystkich dzieci, które są objęte obowiązkiem szkolnym. Dzieci ze specjalnymi potrzebami edukacyjnymi mają mieć zapewnione potrzebne wsparcie, które może obejmować zatrudnienie asystenta do ucznia czy likwidację barier architektonicznych na terenie szkoły. Jeśli stan dziecka, ciężka postać SMA, nie pozwala na uczęszczanie do szkoły, istnieje możliwość odbywania nauki szkolnej w systemie nauczania domowego. Ponadto wśród obowiązków gminy znajduje się też umożliwienie niepełnosprawnym dzieciom dojazdu do szkół. Może się to odbywać na zasadzie zapewnienia transportu dostosowanym pojazdem lub refundacji rodzicom kosztów związanych $\mathrm{z}$ dowozem dziecka ${ }^{17}$.

${ }^{14}$ Lekarze nie do końca byli pewni, czy Hawking cierpiał na SMA, czy też stwardnienie zanikowe boczne ALS (Amoytrophic Lateral Sclerosis - w ostatnich latach jego życia skłaniano się raczej do takiej diagnozy). Choć choroby te różnią się w patomechanizmie ich przebieg jest podobny i w obu chorobach zachowane jest normalne funkcjonowanie intelektualne, a technologie opracowane z myślą o potrzebach Hawkinga wykorzystywane są obecnie w obu chorobach.

${ }_{15}$ Z piekła do raju, DoRzeczy.pl, 21.09.2017, https://dorzeczy.pl/42008/Z-piekla-do-raju.html (dostęp: 5.07.2018).

${ }_{16}$ Konwencja o prawach osób niepełnosprawnych, sporządzona w Nowym Jorku dnia 13 grudnia 2006 r. (Dz.U. z 2012 r. poz. 1169), artykuł 24.

17 A. Łusakowska (red.), dz. cyt., s. 62-63. 
SMA ma charakter postępujący, powoduje ograniczoną sprawność fizyczną, przez co znacznie wpływa na funkcjonowanie uczniów z SMA w szkole. Konieczne jest, aby nauczyciele pracujący z uczniami z SMA zapoznali się ze specyfiką tej choroby i byli świadomi potrzeb, możliwości i ograniczeń swoich uczniów. Zasadne jest również przekazywanie uczniom bez niepełnosprawności, że SMA nie jest chorobą zaraźliwą, a uczniowie nią dotknięci nie stwarzają zagrożenia dla pozostałych uczniów i potrzebują akceptacji, zrozumienia, przyjaźni oraz samorealizacji ${ }^{18}$.

Uczniów z SMA charakteryzuje ograniczone lub uniemożliwione samodzielne poruszanie się. Ich pismo i wykonywane przez nich rysunki mogą być mało czytelne dla nauczyciela. Dodatkowo, z powodu szybkiej męczliwości, jakość pisma spada w miarę pisania - im dłuższy tekst, tym pismo jest mniej czytelne na końcu. Uczniowie przejawiają też trudności podczas mierzenia, szkicowania, posługiwania się przyborami matematycznymi i sprzętem laboratoryjnym. Wykonywanie czynności ruchowych zajmuje im więcej czasu niż ich rówieśnikom. Problematyczne może być dla nich szybkie kartkowanie słowników, zeszytów i książek. Część uczniów z SMA może odczuwać lęk w nowych dla nich sytuacjach ${ }^{19}$.

Wsparcie psychologiczne dla ucznia z niepełnosprawnością jest nieocenione. Często najcenniejsze wsparcie dla osoby dotkniętej chorobą nerwowo-mięśniową pochodzi od innej osoby z podobną chorobą. Zrozumienie stanu ucznia jest ważne w tworzeniu realistycznych oczekiwań wobec niego. Konieczne jest skoncentrowanie się na tym, co uczeń może robić, a nie na tym, czego już nie może. Ponadto należy umożliwić mu podejmowanie własnych decyzji, nawet jeśli fizycznie nie jest w stanie wykonywać określonych zadań. Rodzeństwo ucznia z niepełnosprawnością też potrzebuje wsparcia. Może im towarzyszyć wiele uczuć takich jak zazdrość czy lęk. Ważne jest dla nich poczucie, że jest ktoś, kto z nimi porozmawia i wesprze. Należy uwzględniać potrzeby emocjonalne i psychologiczne wszystkich uczniów. W związku z tym poza samym uczniem z niepełnosprawnością konieczne jest też zwrócenie uwagi na pozostałych uczniów, ponieważ obecność osoby z niepełnosprawnością w klasie wpływa na wszystkich w grupie. Szkoła powinna zadbać o to, żeby temat niepełnosprawności i wynikających $z$ niej potrzeb nie był im obcy ${ }^{20}$. Rodzice uczniów współdecydują o szkole i jej funkcjonowaniu, mają wpływ na działania, które są podejmowane wobec uczniów. Ponadto mają oni w szkole prawa, których realizacji powinni oczekiwać. W momencie, kiedy człowiek doświadcza trudnej dla siebie sytuacji i sam nie jest w stanie sobie $\mathrm{z}$ nią poradzić, potrzebuje wsparcia. Z całą pewnością

18 School Accommodation Recommendations Diagnosis: Spinal Muscular Atrophy (SMA), Muscular Dystrophy Association (br.), https://www.mda.org/sites/default/files/Guide SchoolAccommodations-SMA2.pdf (dostęp: 20.12.2017).

19 A. Olechowska, Specjalne potrzeby edukacyjne, PWN, Warszawa 2016, s. 91-93.

${ }^{20}$ Inclusive education for children with muscular dystrophy and other neuromuscular conditions. Guidance for primary and secondary schools, Muscular Dystrophy Campaign, 2007, http://www. musculardystrophyuk.org/assets/0002/2928/Inclusive Education.pdf (dostęp: 15.07.2018). 
potrzebują go rodzice dziecka $z$ niepełnosprawnością ${ }^{21}$. Nierzadko czują się osamotnieni, zagubieni, czasem nie są w stanie poradzić sobie z zaistniałą sytuacją lub czują zmęczenie z powodu stałej opieki nad dzieckiem. Szkoła, w założeniu, ma spełniać oczekiwania i zaspokajać potrzeby rodziców, tak by każdy z nich mógł czuć się w niej dobrze $^{22}$. Nie bez znaczenia jest perspektywiczne spojrzenie na przyszłość zawodową, gdyż wybory dokonane na etapie szkoły w przypadku osób z poważnymi ograniczeniami sprawności będą mieć znaczenie całożyciowe ${ }^{23}$.

Pracując z uczniem z SMA konieczne jest uwzględnianie jego indywidualnych potrzeb w celu dostosowania środowiska zewnętrznego, w efekcie uczeń może uczestniczyć w życiu klasy i szkoły oraz być w miarę możliwości samodzielny. Kluczowe jest usunięcie barier architektonicznych, gdyż ich istnienie może utrudniać budowanie relacji z innymi, negatywnie wpływać na aktywność i samodzielność ucznia, a w konsekwencji zmniejszać motywację do nauki i rozwoju psychofizycznego. Usunięcie barier stwarza poczucie samodzielności, pogłębia chęć do nauki i współpracy z kolegami i nauczycielami ${ }^{24}$. Przyczyny i skutki funkcjonalne niepełnosprawności ruchowej mogą być różne. Wynika ona z różnorodnych zdarzeń losowych i schorzeń. W zależności od ich rodzaju, stopnia i czasu wystąpienia ograniczona jest samodzielność i niezależność życiowa oraz utrudnione jest opanowanie umiejętności szkolnych.

W literaturze niewiele jest konkretnych wskazówek do pracy z dziećmi z SMA, ale odnosi się do nich także wiele wytycznych do nauczania uczniów z niepełnosprawnością ruchową w ogóle. Dotyczą one przede wszystkim zniesienia barier architektonicznych w szkole i wokół niej ${ }^{25}$. Natomiast jeśli chodzi o dostosowanie o charakterze dydaktycznym, dotyczącym głównie metod nauczania i środków dydaktycznych, warto uwzględnić za A. Olechowską następujące wskazówki:

- umożliwienie uzupełnienia lub dostarczenie doświadczeń, których uczeń nie miał sposobności wcześniej zdobyć;

- dostosowanie podręczników, zeszytów, kart pracy i innych materiałów dydaktycznych w sposób umożliwiający uczniowi możliwie samodzielne korzystanie z nich;

- dostosowanie do możliwości i potrzeb ucznia przyborów szkolnych (ze zwróceniem uwagi na trudności z chwytaniem, manipulacją; powinny mieć odpowiednią grubość i rozmiar, być ergonomiczne), także instrumentów muzycz-

${ }^{21}$ J. Pyżalski, D. Podgórska-Jachnik, Badanie potrzeb i satysfakcji z wybranych usług skierowanych do rodzin z dziećmi z orzeczona niepetnosprawnością w wieku 8-16 lat, RCPS, Łódź 2015.

${ }^{22}$ J. Lipińska-Lokś, Wsparcie rodziców dzieci z niepetnosprawnościa w środowisku szkolnym zielonogórski przykład dobrych praktyk, „Problemy Edukacji, Rehabilitacji i Socjalizacji Osób Niepełnosprawnych", nr 18(1)/2014.

${ }_{23}$ B. Jachimczak, B. Olszewska, D. Podgórska-Jachnik, Mój zawód - moja praca - moja przyszłość: perspektywy osób z niepelnosprawnością, Wydawnictwo WSP, Łódź 2011.

${ }^{24}$ Podniesienie efektywności kształcenia uczniów ze specjalnymi potrzebami edukacyjnymi. Materiały szkoleniowe część II, Ministerstwo Edukacji Narodowej, Warszawa 2010.

${ }_{25}$ A. Olechowska, dz. cyt., s. 93-94. 
nych (nie powinny wymagać precyzyjnego chwytania poszczególnych części i dużego nakładu siły w celu uderzenia; odpowiedni jest np. tamburyn, trójkąt czy talerze);

- dostosowanie stanowiska komputerowego na zajęciach z informatyki;

- zapewnienie dostępu do komputera, jeśli uczeń nie jest w stanie pisać ręcznie;

- ułatwienie dostępu do przedmiotów i pomocy dydaktycznych (obniżenie wysoko wiszących map, umieszczenie eksponatów, brył geometrycznych czy innych poznawanych przedmiotów na ławce ucznia z niepełnosprawnością, do której mogą podchodzić uczniowie bez niepełnosprawności w celu ich obejrzenia $)^{26}$.

Powyższe wskazówki bez wątpienia przełożą się na lepsze rozumienie funkcjonalności uczniów z SMA oraz na ich pełniejsze uczestnictwo w życiu szkolnym i społecznym. Należy jednak pamiętać, że SMA jest chorobą o zróżnicowanym przebiegu, co oznacza, że uczniowie nią dotknięci doświadczają różnorodnych trudności w swoim codziennym funkcjonowaniu. Dlatego nauczyciel powinien zdawać sobie sprawę z tego, że niektóre z powyższych wskazówek nie będą odpowiednie dla danego ucznia z SMA. Ważne jest, żeby był dobrym obserwatorem, potrafił działać adekwatnie do sytuacji.

Podstawowym dokumentem, który reguluje funkcjonowanie ucznia z orzeczeniem w szkole jest IPET. Należy w nim uwzględnić konkretne cele w oparciu o potrzeby ucznia. Ten plan powinien być regularnie kontrolowany i wnikliwie sprawdzany. IPET obejmuje m.in. zakres dostosowań wymagań edukacyjnych, formy i zakres pomocy, wykorzystanie technologii informacyjnych. Należy konsultować zawartość dokumentu z rodzicami ucznia i informować ich o podejmowanych działaniach wobec niego oraz o wszelkich ich rezultatach ${ }^{27}$.

Aby ułatwić uczniom korzystanie $\mathrm{z}$ indywidualnych pomocy dydaktycznych, zdaniem A. Olechowskiej, należy je dostosować poprzez:

- dobranie przyborów do pisania z uwzględnieniem możliwości ucznia;

- stosowanie podpórek pod zeszyty i książki, zapewniających ich stabilizację, także najlepiej przytrzymywanie kartek;

- korzystanie z podręczników w wersji elektronicznej, jeśli uczeń nie ma wystarczająco siły, by swobodnie kartkować podręcznik papierowy (przy tym warto zwrócić uwagę, że obecnie coraz częściej w ogóle wykorzystuje się w dydaktyce książki elektroniczne, co dla dzieci z SMA wydaje się dodatkową szansą - przyp. K.G.);

- przygotowanie trwałych, ofoliowanych pomocy z wykorzystaniem sztywnych kartonów (dodatkowe zabezpieczenie przed przesuwaniem i rozrzuceniem takich pomocy może dać przyklejony rzep - przyp. K.G.);

\footnotetext{
26 Tamże, s. 94-95.

27 Inclusive education for children with muscular dystrophy...
} 
- stosowanie pojedynczych kart pracy, które po zajęciach byłyby umieszczane w segregatorze, rezygnacja z zeszytów może znacznie poprawić komfort pracy ucznia (to także częsty sposób gromadzenia materiałów w formie portfolio w wielu niemieckich, szwedzkich czy amerykańskich szkołach - przyp. K.G.);

- przygotowanie gotowych schematów i tabelek w celu odciążenia ucznia, którego zadaniem będzie tylko ich uzupełnienie lub zaznaczenie właściwych elementów;

- udostępnianie prezentacji wyświetlanych w czasie lekcji, jeśli uczeń ma problemy z szybkim przepisywaniem treści znajdujących się na slajdach;

- przygotowanie notatek z najważniejszymi informacjami z poszczególnych lekcji ${ }^{28}$. Jak widać, dostosowania te nie wymagają wielkiego wysiłku ze strony nauczyciela, raczej empatycznej troski, wyobraźni i odrobiny kreatywności, a czasem także rezygnacji z utartych sposobów pracy na lekcji na rzecz poszukiwania nowoczesnych sposobów zagospodarowania przestrzeni, podejścia do sposobu wykonywania zadań, używanych pomocy. Może to wręcz wpłynąć na urozmaicenie sposobu pracy na lekcji i ich uatrakcyjnienie dla wszystkich uczniów. Obecność ucznia z SMA w klasie szkolnej stanowi zatem pewne wyzwanie, ale nieprzekraczające możliwości sprostania mu przez nauczyciela, nawet przeciętnie przygotowanego do pracy z dzieckiem z niepełnosprawnością. Z pewnością nie stanowi zagrożenia dla jakości nauczania w klasie, a nawet może przyczynić się do jej podniesienia. Tak zresztą postrzegana jest współcześnie rola edukacji włączającej.

\section{Refleksje końcowe}

SMA to choroba, w której mięśnie ciała słabną i ulegają zanikowi. Dotyczy to m.in. mięśni rąk, nóg, mięśni przewodu pokarmowego i mięśni odpowiadających za oddychanie. SMA nie wpływa na rozwój emocjonalny i intelektualny. Chorzy na SMA to często osoby inteligentne, osiągające liczne sukcesy i otwarte na otoczenie. Jeszcze niedawno była to choroba nieuleczalna, a jedyną pomocą była rehabilitacja, która w niewielkim stopniu usprawniała osoby dotknięte SMA i spowalniała postęp choroby. Jednak w ostatnim czasie pojawił się pierwszy na świecie lek, który nie tylko zatrzymuje postęp tej choroby, ale też często cofa jej objawy. To bez wątpienia ogromna szansa dla chorych na SMA na znaczną poprawę ich funkcjonowania.

Kształcenie ucznia z SMA nie należy do najłatwiejszych zadań, ale szkoła i nauczyciele mogą mu sprostać. Istotne jest to, żeby działać w kierunku wzmacniania samooceny ucznia i uświadamiać go, że pomimo znacznej niepełnosprawności ruchowej jest w stanie dużo osiągnąć w życiu. Pomocne mogą tu być kontakty z dorosłymi ludźmi z SMA, którzy mogą stanowić wzorzec osobowy dla takiego ucznia. Ponadto zaangażowanie nauczyciela w wykonywaną pracę, podporządkowywanie się

\footnotetext{
${ }^{28}$ A. Olechowska, dz. cyt., s. 95-96.
} 
zaleceniom i jego troska o ucznia z całą pewnością pomogą uczniowi rozwijać swoje zainteresowania i osiągnąć założone cele, co też bez wątpienia przełoży się na satysfakcję nauczyciela i poczucie prawidłowo wykonanej pracy. Z pewnością znajdzie ona odzwierciedlenie w dalszym rozwoju ucznia, nie tylko w odniesieniu do szkoły, lecz również w późniejszym życiu zawodowym. Poprzez wzmocnienie samooceny i motywowanie do stawiania sobie ambitnych celów osoba z SMA może uświadomić sobie własną wartość, dążyć do samorealizacji i samoakceptacji. Wzbudzenie w młodym człowieku poczucia przynależności społecznej prowadzi do wytworzenia w późniejszym okresie poczucia wspólnoty i założenia własnej rodziny.

\section{Bibliografia}

Arnold W.D., Kassar D., Kissel J.T., Spinal muscular atrophy: diagnosis and management in a new therapeutic era, „Muscle Nerve.”, nr 51(2)/2015.

Borkowska J. i in., Incidence of spinal muscular atrophy in Poland - more frequent than predicted?, „Neuroepidemiology”, nr 34/2010.

Inclusive education for children with muscular dystrophy and other neuromuscular conditions. Guidance for primary and secondary schools, Muscular Dystrophy Campaign, 2007, http://www.musculardystrophyuk.org/assets/0002/2928/ Inclusive Education.pdf (dostęp: 15.07.2018).

Jachimczak B., Dydaktyczne i pozadydaktyczne uwarunkowania efektów nauczania indywidualnego dzieci przewlekle chorych, Oficyna Wydawnicza Impuls, Kraków 2011.

Jachimczak B., Olszewska B., Podgórska-Jachnik D., Mój zawód - moja praca - moja przyszłość: perspektywy osób z niepełnosprawnością, Wydawnictwo WSP, Łódź 2011.

Jędrzejowska M., Dosiebny dziecięcy i młodzieńczy rdzeniowy zanik mięśni - podłoże molekularne a fenotyp choroby, praca na stopień doktora nauk medycznych wykonana w Instytucie Medycyny Doświadczalnej i Klinicznej im. M.J. Mossakowskiego Polskiej Akademii Nauk, Warszawa 2003.

Konwencja o prawach osób niepełnosprawnych, sporządzona w Nowym Jorku dnia 13 grudnia 2006 r. (Dz.U. z 2012 r. poz. 1169).

Lipińska-Lokś J., Wsparcie rodziców dzieci z niepełnosprawnościa w środowisku szkolnym - zielonogórski przykład dobrych praktyk, „Problemy Edukacji, Rehabilitacji i Socjalizacji Osób Niepełnosprawnych”, nr 18(1)/2014.

Łusakowska A. (red.), Rdzeniowy zanik mięśni (SMA) - podstawowe informacje, Fundacja SMA, Warszawa 2016.

Mastella Ch., Ottonello G. (red.), Z SMA1 na co dzień - Vademecum opieki nad dzieckiem z najcięższa postacią rdzeniowego zaniku mięśni, Fundacja SMA, Warszawa 2016. 
Nusinersen, https://www.fsma.pl/leki/nusinersen/ (dostęp: 15.01.2018).

Olechowska A., Specjalne potrzeby edukacyjne, PWN, Warszawa 2016.

Podniesienie efektywności kształcenia uczniów ze specjalnymi potrzebami edukacyjnymi. Materiały szkoleniowe czesść II, Ministerstwo Edukacji Narodowej, Warszawa 2010.

Pieczyńska B., Uczniowie z Konina napisali list do premier Szydło w sprawie SMA, „Głos Wielkopolski”, 30.10.2016, http://www.gloswielkopolski.pl/wiadomosci/konin/a/uczniowie-z-konina-napisali-list-do-premier-szydlo-w-sprawie-sma,11202684/ (dostęp: 14.07.2018).

Pyżalski J., Podgórska-Jachnik D., Badanie potrzeb i satysfakcji z wybranych usług skierowanych do rodzin z dziećmi z orzeczona niepełnosprawnościa w wieku 8-16 lat, RCPS, Łódź 2015.

Rozporządzenie Ministra Edukacji Narodowej z dnia 9 sierpnia 2017 r. w sprawie warunków organizowania kształcenia, wychowania i opieki dla dzieci i młodzieży niepełnosprawnych, niedostosowanych społecznie i zagrożonych niedostosowaniem społecznym (Dz.U. z 2017 r. poz. 1578).

Rozporządzenie Ministra Edukacji Narodowej z dnia 9 sierpnia 2017 r. w sprawie zasad udzielania i organizacji pomocy psychologiczno-pedagogicznej w publicznych przedszkolach, szkołach i placówkach (Dz.U. z 2017 r. poz. 1591).

Rozporządzenie Ministra Edukacji Narodowej z dnia 7 września 2017 r. w sprawie orzeczeń i opinii wydawanych przez zespoły orzekające działające w publicznych poradniach psychologiczno-pedagogicznych (Dz.U. z 2017 r. poz. 1743).

School Accommodation Recommendations Diagnosis: Spinal Muscular Atrophy (SMA), Muscular Dystrophy Association (br.), https://www.mda.org/sites/default/ files/Guide SchoolAccommodations-SMA2.pdf (dostęp: 20.12.2017).

Ślusarczyk Cz., Rola i znaczenie technologii informacyjnych $w \dot{z} y c i u$ osób niepetnosprawnych, „Ekonomiczne Problemy Usług”, nr 57/2010.

Walewski P., Wyjść z bezruchu, „Polityka”, 1-7.08.2018, nr 31(3171).

Z piekła do raju, DoRzeczy.pl, 21.09.2017, https://dorzeczy.pl/42008/Z-piekla-do-raju.html (dostęp: 5.07.2018). 


\section{Special educational needs of students with spinal muscular atrophy (SMA)}

Abstract: Inclusive education requires all teachers to become acquainted with various disabilities that they may encounter in their professional practice. The aim of this article is to present the situation of students with a specific neurodegenerative disease - spinal muscular atrophy (SMA). This disease causes physical disability, but it does not affect intellectual ability, so before teachers - mainly in mainstream schools, because that is where students learn most often - is a challenge related to creating conditions to meet their special educational needs and enable self-realisation, despite increasing limitations. The article presents the characteristics of SMA, highlighting its threats and effects. The article shows the functional limitations that may affect the possibilities of learning. The final part of the article presents the character of special educational needs and support opportunities for students with SMA, including adaptation of teaching organisation, teaching methods and teaching aids.

Keywords: spinal muscular atrophy, SMA, education, student, special educational needs, inclusive education

About the author: Karolina Gniazdowska - PhD student in Pedagogy at Kazimierz Wielki University; research interests: inclusive education, Convention on the Rights of Persons with Disabilities, social exclusion of women with disabilities, sexuality of women with disabilities. 


\title{
Internet a wychowanie - na przykładzie Katolickiej Szkoły Podstawowej im. Piotra Dunina w Chojnicach
}

DOI: 10.25312/2083-2923.15/2019_10rf

\begin{abstract}
Streszczenie: Artykuł podejmuje problematykę wpływu Internetu na wychowanie osoby ludzkiej na przykładzie Katolickiej Szkoły Podstawowej im. Piotra Dunina w Chojnicach. W celu prześledzenia tej problematyki zastosowano empiryczne badanie, określające stopień bezpiecznego korzystania z Internetu i mediów społecznościowych przez uczniów placówki, jego możliwy wpływ na wychowanie oraz sprawdzenie, czy szkoła realizuje koncepcję pracy ukierunkowaną na rozwój osobowy uczniów. Badanie pokazało, że ilość spędzanego czasu przy komputerze ma wpływ na kształtowanie się procesu wychowawczego. Świadomi są tego rodzice i nauczyciele, podejmujący odpowiednie kroki, zgodnie z programem wychowawczo-profilaktycznym szkoły. Choć ilość czasu spędzanego w sieci przez uczniów tej szkoły nie jest zatrważająca, środowisko rodzicielskie i szkolne podejmuje odpowiednie działania mające na celu kontrolę i ograniczenie stosowania Internetu jako środka burzącego równowagę personalistycznego wychowania.
\end{abstract}

Słowa kluczowe: Internet a wychowanie, bezpieczeństwo w sieci, wychowanie personalistyczne

\section{Wprowadzenie}

Proces kształtowania osobowości odbywa się na wielu polach ludzkiej aktywności. O jego powodzeniu decydują takie aspekty, jak: środowisko, predyspozycje wrodzone, wychowanie, aktywność własna, która w dużym stopniu zdominowana została współcześnie przez Internet. Jego wpływ można obserwować niemal we wszystkich

* Rafał Maliszewski - doktor nauk humanistycznych, filozof, pedagog, językoznawca, kaszubolog; absolwent filozofii KUL i Wyższej Szkoły Filozoficznej w Monachium. Doktorat z socjolingwistyki w Instytucie Filologii Germańskiej na Uniwersytecie Gdańskim. 
dziedzinach ludzkiej działalności, choć najbardziej znaczące wydają się dwa wzajemnie na siebie oddziałujące zakresy: komunikowanie i wychowanie.

Nikt współcześnie nie ma wątpliwości, że nowoczesne media, których podstawę stanowi Internet, na dobre zagościły w życiu prywatnym i zawodowym. Stanowią one integralną część współczesnego szkolnictwa, gdzie kreatywność, innowacja i efektywność zajmują czołowe miejsce. Nie da się ukryć, że wprowadzenie Internetu do szkolnictwa unowocześniło i uatrakcyjniło szkołę, otwarło inny wymiar komunikacyjny pomiędzy uczniami, nauczycielami, dyrekcją, rodzicami oraz umożliwiło przeprowadzanie projektów o randze międzynarodowej. Wszystkie te aspekty mogą przyczynić się do poszerzania wśród uczniów zdolności twórczych, rozwijania talentów oraz kreowania swojej przyszłości na podstawie doświadczeń zdobytych za pośrednictwem sieci.

Choć Internet to medium odgrywające ważną rolę w życiu młodego człowieka, niektórzy naukowcy zaliczają je do najbardziej kontrowersyjnych fenomenów kultury' ${ }^{1}$. Do jednego z istotnych zagrożeń Internetu zaliczyć należy niebezpieczeństwo zacierania się granic pomiędzy prawdą realną a konstruktem wirtualnym. W środowisku szkolnym można spotkać uczniów utrzymujących kontakt ze swoimi rówieśnikami tylko poprzez sieć, a budowanie relacji opartych na spotkaniach interpersonalnych przekracza ich możliwości. Wspomnieć należy również o fizycznych i społecznych konsekwencjach nadużywania Internetu. Do problemu natury fizycznej, związanego z niegospodarnością czasem w sieci, zaliczyć należy nadwyrężanie mięśni nadgarstka, bóle kręgosłupa, wady wzroku itp. Natomiast jedno z wielu społecznych niebezpieczeństw nadużywania Internetu przejawia się w przestęppczości komputerowej, seksualnej, marketingowej, cyberprzemocy, nielegalnym kopiowaniu i zamieszczaniu materiałów ${ }^{2}$.

Na potrzeby niniejszego artykułu przeprowadzone zostały w maju i czerwcu 2018 roku badania ewaluacyjne skierowane do losowo wybranych z szóstej i siódmej klasy uczniów Katolickiej Szkoły Podstawowej im. Piotra Dunina w Chojnicach oraz losowo wybranych rodziców i nauczycieli. Wybór szkoły uwzględniał preferencje badawcze autora artykułu. Na pytania ewaluacyjne odpowiedziało 63 lub 62 uczniów. W celu potwierdzenia wiarygodności uzyskanych przez uczniów odpowiedzi, pytania o charakterze weryfikacyjnym zadano 39 lub 29 rodzicom oraz 20 nauczycielom. Uczniowie odpowiadali na 12 pytań ewaluacyjnych, a rodzice i nauczyciele na 10. Było to badanie o charakterze analityczno-syntetyzującym, diagnostycznym oraz

${ }^{1}$ Zob. M. Castells, Galaktyka Internetu. Refleksje nad Internetem, biznesem i społeczeństwem, Rebis, Poznań 2003, s. 18.

2 Parry Aftab wylicza sześć rodzajów zagrożeń płynących z Internetu, dotykających szczególnie dzieci: 1. Nieodpowiednie treści; 2. Możliwość korzystania z niebezpiecznych usług; 3 . Wirtualne spotkanie niebezpiecznych ludzi; 4. Ujawnienie danych osobowych; 5. Oszustwo i wykorzystanie; 6. Uwodzenie, zob. P. Aftab, Internet a dzieci. Uzależnienia i inne niebezpieczeństwa, Wydawnictwo Prószyński i S-ka, Warszawa 2003, s. 84. 
anonimowym. Pytania zamieszczone w kwestionariuszu ankietowym miały profil nominalny, czyli stwierdzający obecność lub nieobecność danego zjawiska, oraz charakter porządkowy, badający stopień zaawansowania danego zjawiska. Jako dodatkową metodę badawczą zastosowano wywiad antropologiczny ${ }^{3}$. Decyzja o poszerzeniu badań o wywiad antropologiczny była jak najbardziej słuszna, pozwoliła bowiem osiągnąć cele badawcze trudne do wyrażenia tylko poprzez ankietę 4 . Za cel ewaluacji postawiono sobie zbadanie stopnia bezpiecznego korzystania z Internetu i mediów społecznościowych przez uczniów placówki, jego możliwego wpływu na wychowanie oraz sprawdzenie, czy szkoła realizuje koncepcję pracy ukierunkowaną na rozwój osobowy uczniów. Postawiono w tym zakresie cztery pytania kluczowe:

1. Czy bezpiecznie korzystam z mediów społecznościowych?

2. Czy szkolna pracowania jest dobrze zabezpieczona przed wchodzeniem na strony zawierające treści niebezpieczne dla uczniów?

3. Czy uczniowie, rodzice i nauczyciele znają program wychowawczo-profilaktyczny szkoły?

4. Jakie działania wychowawcze (jakiej jakości) są podejmowane w szkole i czy są one adekwatne z zapisami programu wychowawczo-profilaktycznego szkoły?

Jako kryteria badawcze przyjęto następujące tezy:

1. Internet to jedno ze źródeł pozyskiwania informacji niezbędnych do poszerzenia wiedzy przez uczniów.

2. Internet stwarza uczniom dostęp do informacji, wdraża do samodzielnego poszukiwania wiadomości oraz inspiruje do kreatywnego korzystania z mediów społecznościowych, ale jednocześnie stwarza wiele niebezpieczeństw.

3. Szkoła uczy bezpiecznego korzystania z Internetu i posługiwania się mediami społecznościowymi.

4. Uczniowie, rodzice i nauczyciele znają program wychowawczo-profilaktyczny szkoły.

5. Szkoła podejmuje działania wychowawcze zgodnez programem wychowawczo-profilaktycznym.

\section{Misja wychowawczo-profilaktyczna szkoły}

Katolicka Szkoła Podstawowa im. Piotra Dunina w Chojnicach (KSP) powołana została do istnienia 1 września 1991 roku. Ministerstwo Edukacji Narodowej przychyliło się do wniosku Stowarzyszenia Rodzin Katolickich Diecezji Chełmińskiej

${ }^{3}$ Założenia metody wywiadu antropologicznego opisują: M. Hammersley, P. Atkinson, Metody badań terenowych, Zysk i S-ka, Poznań 2000, s. 92.

${ }^{4}$ Zastosowanie $\mathrm{w}$ badaniu zróżnicowanych metod w celu otrzymania podstaw empirycznych koniecznych do wnioskowania nazywane jest w literaturze triangulacją, por. M. Kostera, Antropologia organizacji. Metodologia badań, Wydawnictwo Naukowe PWN, Warszawa 2003, s. 97-98. 
w Chojnicach o utworzenie pierwszej w Diecezji Chełmińskiej (dzisiejszej Diecezji Pelplińskiej) szkoły katolickiej. Była to również jedna z pierwszych szkół katolickich powstałych w Polsce po roku 1989. Kierowaniem tej publicznej placówki zajęła się urzędująca do dzisiaj mgr Marianna Ziarno, a prefektem szkolnym został ks. mgr Jarosław Kaźmierczak, pełniący tę funkcję również obecnie. Siedzibą szkoły stał się poklasztorny budynek augustiański przy ul. Grunwaldzkiej

Specyfika wychowawcza KSP zapisana została w dokumentach szkolnych, takich jak: statut, program wychowawczo-profilaktyczny, programy nauczania, dokumentacja wewnątrzszkolna, i w sposób bezpośredni nawiązuje do misji wychowawczej Kościoła katolickiego opartej na wychowaniu klasycznym i personalistycznym. Najważniejszy szkolny dokument prawny, jakim jest statut, jasno określa zasady i cele wychowawcze szkoły (art. 4, ust. 1-3): „Całokształt działalności szkoły opiera się na systemie wartości chrześcijańskich głoszonych przez Kościół katolicki [...] Wychowanie i nauczanie w szkole oparte jest na koncepcji człowieka jako osoby głoszonej przez Kościół katolicki, w szczególności na myśli i nauce św. Jana Pawła II o godności osoby ${ }^{6}$. Wychowanie personalistyczne realizowane $\mathrm{w}$ tej szkole wyrasta $\mathrm{z}$ koncepcji człowieka jako osoby z jej statusem fizyczno-psychiczno-duchowym przy konieczności rozwoju aktywnego procesu stawania się osobą, tak aby być zdolnym do rozumienia siebie, otaczającego świata oraz gotowym do podejmowania odpowiedzialnych wyborów. Stawanie się osobą powinno być wynikiem dostrzeżenia możliwości świadomego budowania siebie jako osoby. Wychowanek powinien dostrzec, że może autonomicznie budować siebie jako osobę, a więc budować w sobie dobro. Jest to rodzaj samowychowania, które zakłada możliwość wolnego rozstrzygania na rzecz rozpoznanego dobra. Toteż stanowienie siebie jako osoby może dokonywać się także przy pomocy nauczycieli-wychowawców. Statut szkoły mówi o osobowej relacji nauczyciela i ucznia oraz o świadectwie życia dawanym przez wychowawcę: „Podstawową zasadą pracy nauczyciela jest kierowanie się dobrem uczniów, troską o ich zdrowie, postawą moralną i obywatelską, poszanowaniem godności ucznia oraz dawaniem dobrego przykładu życia w szkole i poza nią" (Statut KSP, art. 42, ust. 2) ${ }^{7}$.

W pierwszej kolejności jest tu mowa o osobowej relacji, oznaczającej specyficzny kontakt z inną osobą (tutaj nauczycielem), ukazującym osobową godność jako wyróżnik przysługujący każdemu człowiekowi. Ta relacja osobowa ma na celu przypominać wychowankowi, kim jest, jaką wartość posiada, jaki jest sens jego życia. W KSP podkre-

${ }^{5}$ Prefekt KLO - ks. Jarosław Kaźmierczak - mówi o realizowanym w szkole klasycznym wychowaniu, którego nadrzędnym celem będzie osobista więź każdego członka społeczności szkolnej z Chrystusem, zob. J. Kaźmierczak (red.), XX-lecie Wspólnoty Szkół Katolickich w Chojnicach, Chojnice 2011, s. 18. Benedykt XVI pisze, że „każda katolicka instytucja oświatowa jest w pierwszej kolejności miejscem spotkania z żyjącym Bogiem, który w Jezusie Chrystusie objawia swoją przemieniającą miłość i prawdę [...], Benedykt XVI, Przemówienie na Katolickim Uniwersytecie Ameryki, 17.04.2008, „L'Osservatore Romano”, nr 5/2008, s. 49.

${ }^{6}$ Zob. http://katolikchojnice.c0.pl/dokumenty/ (dostęp: 5.11.2018).

7 Tamże. 
śla się, że budowanie takiej relacji możliwe jest dzięki obustronnemu zaufaniu. Zaufanie z kolei musi zostać wypracowywane dzięki prawdziwemu spotkaniu wychowawcy i wychowanka, poświęceniu mu swojego czasu, zainteresowaniu się jego problemami. Poczucie zaufania w dużej mierze przyczynia się do szczególnej troski o bezpieczeństwo ucznia, do czego również wzywa statut szkoły i program wychowawczo-profilaktyczny.

Do jednego z głównych celów wychowawczych i opiekuńczych szkoły należy dbanie o bezpieczeństwo uczniów i ochronę ich zdrowia: „Szkoła pomaga uczniom w ich rozwoju poprzez stworzenie bezpiecznej i twórczej atmosfery procesu nauczania ${ }^{8 ”}$. Program wychowawczo-profilaktyczny skonstruowany jest na podstawie Ośmiu błogosławieństw wygłoszonych przez Jezusa podczas kazania na górze. Proces wychowania zapisany w tym programie obejmuje całą osobowość człowieka i wszystkie etapy jego życia. Dotyczy rozwoju duchowego, intelektualnego, emocjonalnego, fizycznego, społecznego oraz gwarantuje podejmowanie działań służących bezpieczeństwu uczniów, również w kontekście zagrożeń internetowych. W ramach ochrony przed niebezpieczeństwem związanym z nadużywaniem lub niewłaściwym używaniem Internetu proponuje się bieżącą współpracę $\mathrm{z}$ wychowawcą, pedagogiem lub psychologiem szkolnym. W ramowy plan pracy wpisane są pogawędki dla uczniów, szkolenia specjalistów oraz pedagogizacja rodziców na temat bezpiecznego korzystania z Internetu. Wiedzę z tego zakresu przekazuje się uczniom głównie podczas godzin wychowawczych oraz tzw. kwadransu wychowawczego. Każdego dnia o godz. 7.45 wychowawcy spotykają się ze swoimi podopiecznymi na rozmowie wychowawczej. Omawiane są problemy wychowawcze dotyczące całej społeczności klasowej. Sferę kontaktu wychowawczego poruszającego problemy zagrożeń w sieci dopełniają liczne wyjazdy o charakterze szkoleniowym, doświadczalnym oraz prewencyjnym.

\section{Analiza przeprowadzonego badania}

W badaniu ewaluacyjnym przeznaczonym dla uczniów zadano 12 pytań mających na celu ustalenie stopnia występowania danego zjawiska oraz jego wpływu na aspekt wychowawczy uczniów uczęszczających do Katolickiej Szkoły Podstawowej im. Piotra Dunina w Chojnicach. Oto wyniki badania:

Tabela 1. lle godzin spędzasz w Internecie?

\begin{tabular}{|l|c|}
\hline \multicolumn{1}{|c|}{ Liczba godzin } & Wynik procentowy \\
\hline $0-2$ & $46,03 \%$ \\
\hline $2-4$ & $25,40 \%$ \\
\hline 4 i więcej & $22,22 \%$ \\
\hline Wcale & $6,35 \%$ \\
\hline
\end{tabular}

\footnotetext{
${ }^{8}$ Koncepcja pracy KSP, http://katolikchojnice.c0.pl/dokumenty/ (dostęp: 5.11.2018).
} 
46,03\% uczniów spędza w Internecie od 0-2 godzin dziennie. 25,4\% poświęca Internetowi od 2-4 godzin dziennie, a 14 uczniów (tj. 22,22\%) spędza w sieci 4 i więcej godzin. Stosunkowo mały odsetek - 6,35\% (tj. 4 uczniów) - nie korzysta z Internetu w ogóle. Pozytywnie może nastrajać fakt, że najwięcej uczniów spędza przed komputerem maksimum 2 godziny dziennie. Gdyby jednak połączyć drugi i trzeci wynik, uczniów spędzających czas w Internecie w przedziale czasowym od 2 i więcej godzin dziennie byłoby aż 47,62\%.

Tabela 2. lle godzin korzystasz z mediów społecznościowych (komputer, komórka, tablet itp.)?

\begin{tabular}{|l|c|}
\hline \multicolumn{1}{|c|}{ Liczba godzin } & Wynik procentowy \\
\hline $0-2$ & $36,51 \%$ \\
\hline $2-4$ & $23,81 \%$ \\
\hline 4 i więcej & $20,63 \%$ \\
\hline Wcale & $9,52 \%$ \\
\hline Nie wiem & $9,52 \%$ \\
\hline
\end{tabular}

Pytanie dotyczące korzystania z mediów społecznościowych nie ograniczyło się tylko do korzystania z komórki czy tabletu - narzędzi najczęściej używanych przez uczniów podczas przerw lekcyjnych. W badaniu uwzględniono czas poświęcany mediom społecznościowym przy użyciu komputera stacjonarnego w domu, najczęściej po powrocie ze szkoły. Z badania wynika, że najliczniejsza grupa uczniów korzysta z mediów społecznościowych od 0-2 godzin dziennie (36,51\%), następnie 23,81\% uczniów korzysta $\mathrm{z}$ mediów społecznościowych w przedziale 2-4 godzin, a powyżej 4 godzin z mediów społecznościowych korzysta 13 uczniów (20,63\%). Z mediów społecznościowych nie korzysta 6 uczniów i tyle samo nie potrafiło odpowiedzieć na zadane pytanie.

Na podstawie uzyskanego wyniku można stwierdzić, że pytanie na temat ilości czasu poświęconego mediom społecznościowym w zasadzie pokrywa się z pytaniem o ilość czasu poświęconego Internetowi. Wyniki w badanym zakresie kształtują się porównywalnie.

Tabela 3. Ile lat trzeba mieć, żeby korzystać z Facebooka?

\begin{tabular}{|l|c|}
\hline \multicolumn{1}{|c|}{ Wiek } & Wynik procentowy \\
\hline 10 & $3,17 \%$ \\
\hline 13 & $65,08 \%$ \\
\hline 15 & $15,87 \%$ \\
\hline Nie wiem & $15,87 \%$ \\
\hline
\end{tabular}

Rzekoma powszechność korzystania przez uczniów z mediów społecznościowych uprawniła do postawienia pytania na temat świadomości regulacji prawnych 
dotyczących Facebooka. Zadano pytanie dotyczące wieku, jaki trzeba osiągnąć, aby prawomocnie korzystać z Facebooka. Okazało się, że większość uczniów poprawnie określiła wiek uprawniający do rejestracji na portalu społecznościowym Facebook (65,08\%). Dziesięcioro uczniów (tj. 15,87\%) uznało, że aby korzystać z Facebooka, należy ukończyć 15 lat, 3,17\% stwierdziło, że już od 10. roku życia można korzystać z tego portalu społecznościowego, a 15,87\% uczniów nie potrafiło udzielić żadnej odpowiedzi. Znaczna większość uczniów posiada świadomość regulacji prawnych związanych z korzystaniem z tego portalu społecznościowego.

Tabela 4. Do czego wykorzystujesz Internet i aplikacje?

\begin{tabular}{|l|c|}
\hline \multicolumn{1}{|c|}{ Wybór odpowiedzi } & Wynik procentowy \\
\hline Do nauki & $14,29 \%$ \\
\hline Do kontaktów i nauki & $15,87 \%$ \\
\hline Do gier i nauki & $46,03 \%$ \\
\hline Do nauki i do kontaktów towarzyskich & $20,63 \%$ \\
\hline Tylko do nauki i do pracy & $3,17 \%$ \\
\hline
\end{tabular}

Kolejne pytanie, które zostało zadane uczniom, brzmiało: „Do czego wykorzystujesz Internet i aplikacje?”. Aż 46,03\% uczniów odpowiedziało, że czas spędzony w sieci wykorzystuje do gier i nauki. Korzystanie z Internetu tylko w celach naukowych zadeklarowało 14,29\% uczniów, do kontaktów i nauki - 15,87\%, do nauki i do kontaktów towarzyskich - 20,63\%, a tylko do nauki i do pracy zaledwie 3,17\%. Z przedstawionej statystyki można wysnuć wniosek, że spora część uczniów korzysta z Internetu w celach rozrywkowych. Wykorzystują go głównie do gier. Szczegółowa informacja uzyskana $\mathrm{z}$ ankiet, $\mathrm{z}$ uwzględnieniem podziału na płeć, podaje, że wśród uczniów, którzy udzielili odpowiedzi „do gier i nauki” jest aż 72\% chłopców. Na podstawie uzyskanych wyników badawczych można stwierdzić, że głównie chłopcy wykorzystują Internet do współzawodnictwa w postaci gier.

Tabela 5. Czy byłaś/byłeś szykanowany, czy byłaś/byłeś obiektem obraźliwych żartów/kpin?

\begin{tabular}{|l|c|}
\hline Wybór odpowiedzi & Wynik procentowy \\
\hline Tak & $25,4 \%$ \\
\hline $\mathrm{Nie}$ & $74,6 \%$ \\
\hline
\end{tabular}

Wysoki odsetek uczniów wykorzystujących Internet do nawiązywania nowych znajomości, utrzymywania kontaktów lub komunikowania się wymusił zadanie pytania o cyberprzemoc. Stosowanie szykan, wulgaryzmów, złośliwości w sieci jest praktyką dość powszechną wśród młodzieży, a jednocześnie najbardziej niezbadaną. Cyberprzemoc pozostaje tematem tabu wśród młodzieży i należy do precedensów rzadko zgłaszanych instytucjom zajmującym się tego typu przestępstwami. Na pyta- 
nie: „Czy byłaś/byłeś szykanowany, czy byłaś/byłeś obiektem żartów/kpin w sieci?”, aż $74,6 \%$ uczniów KSP odpowiedziało, że nie dochodziło do takich sytuacji. Natomiast $25,4 \%$ odpowiedziało, że sytuacje takie miały miejsce.

Tabela 6. Czy w szkolnej pracowni komputerowej możesz wchodzić na wszystkie strony internetowe?

\begin{tabular}{|l|c|}
\hline Wybór odpowiedzi & Wynik procentowy \\
\hline Tak & $14,29 \%$ \\
\hline Nie & $85,71 \%$ \\
\hline
\end{tabular}

Aż 85,71\% respondowanych uczniów stwierdziło, że w szkolnej pracowni komputerowej nie można wchodzić na wszystkie strony internetowe, natomiast $14,29 \%$ uczniów odpowiedziało, że jest to możliwe.

Tabela 7. Czy rodzice ustalili z tobą zasady korzystania z Internetu (pory, strony, aplikacje)?

\begin{tabular}{|l|c|}
\hline Wybór odpowiedzi & Wynik procentowy \\
\hline Tak & $54,84 \%$ \\
\hline Nie & $45,16 \%$ \\
\hline
\end{tabular}

Kolejne pytanie dotyczyło współpracy uczniów i rodziców co do zakresu korzystania z Internetu. Zapytano, „Czy rodzice ustalili z Tobą zasady korzystania z Internetu (pory dnia, strony internetowe, rodzaje aplikacji)?”. Ponad połowa uczniów $(54,84 \%)$ odpowiedziała, że zasady takie zostały ustalone, jednak spory odsetek uczniów $(45,16 \%)$ nie dokonał z rodzicami takich regulacji. Wydaje się, że stosunkowo duża liczba uczniów nie przedyskutowała ze swoimi rodzicami zasad korzystania $\mathrm{z}$ Internetu. Zjawisko to wydaje się tym bardziej niepokojące w kontekście wieku uczniów (13-14 lat). Dzieci w tym wieku są łatwowierne, ułudnie pozbawione ograniczeń, otwarte na nowe znajomości, charakteryzujące się przyswajalnością najróżniejszych treści, często posiadających destrukcyjny wpływ na rozwój ich osobowości. Tak wysoki wskaźnik braku ustaleń między rodzicami i dziećmi zasad korzystania z Internetu wydaje się dość niepokojącym zjawiskiem.

Tabela 8. Czy rodzice rozmawiają z tobą na temat tego, co robisz w Internecie?

\begin{tabular}{|l|c|}
\hline \multicolumn{1}{|c|}{ Wybór odpowiedzi } & Wynik procentowy \\
\hline Bardzo często & $8,06 \%$ \\
\hline Często & $19,35 \%$ \\
\hline Od czasu do czasu & $30,65 \%$ \\
\hline Rzadko & $25,81 \%$ \\
\hline Nigdy & $16,13 \%$ \\
\hline
\end{tabular}


Znaczny odsetek uczniów twierdzi, że rodzice rozmawiają z nimi o tym, co robią w Internecie. Częstotliwość tych rozmów jest jednak bardzo różna. Tylko 8,06\% uczniów zaznacza, że rozmowy te odbywają się bardzo często, 19,35\% - często, 30,65\% - od czasu do czasu, 25,81\% - rzadko. 16,13\% uczniów twierdzi, że w ogóle nie podejmują dyskusji z rodzicami na ten temat.

Tabela 9. Czy twoi rodzice mają wpływ na to, jakiego typu informacje zamieszczasz w Internecie?

\begin{tabular}{|l|c|}
\hline Wybór odpowiedzi & Wynik procentowy \\
\hline Tak & $50 \%$ \\
\hline Nie & $50 \%$ \\
\hline
\end{tabular}

Połowa ankietowanych stwierdziła, że rodzice mają wpływ na to, jakie informacje ich dzieci zamieszczają w Internecie, druga połowa była odmiennego zdania. Odpowiedzi na to pytanie pokazują, że w przypadku połowy rodziców zamieszczanie w Internecie treści o różnym charakterze nie jest w żaden sposób kontrolowane. Widać w tym zakresie stosunkowo duży brak kontroli rodziców, co nie sprzyja właściwemu kształtowaniu procesu wychowawczego. Wiedza o rodzaju treści zamieszczanych przez dzieci w Internecie pozwala podjąć odpowiednie kroki zmierzające do wyeliminowania działań destruktywnych wychowawczo. Brak tej wiedzy jedynie pogłębia bierność wychowawczą rodziców.

Tabela 10. Czy korzystasz z Internetu głównie do grania, czy do nauki (np. portale edukacyjne)?

\begin{tabular}{|l|c|}
\hline \multicolumn{1}{|c|}{ Wybór odpowiedzi } & Wynik procentowy \\
\hline Tylko gram & $22,58 \%$ \\
\hline Gram i korzystam z portali edukacyjnych & $69,35 \%$ \\
\hline Tylko korzystam z portali edukacyjnych & $8,06 \%$ \\
\hline
\end{tabular}

Największą grupą ankietowanych (69,35\%) okazali się uczniowie, którzy komputer wykorzystują do grania i nauki poprzez portale edukacyjne. Niestety, spora grupa uczniów (22,58\%) wykorzystuje Internet tylko do gier online. Najmniej liczną grupą są uczniowie korzystający z Internetu tylko w celach edukacyjnych - 8,06\%.

Tabela 11. Czy zawierasz nowe znajomości przez Internet?

\begin{tabular}{|c|c|}
\hline Wybór odpowiedzi & Wynik procentowy \\
\hline Tak & $33,87 \%$ \\
\hline Nie & $66,13 \%$ \\
\hline
\end{tabular}


Większość uczniów $(66,13 \%)$ nie zawiera nowych znajomości przez Internet. Jednak 33,87\% wykorzystuje głównie portale społecznościowe do zawierania nowych znajomości.

Zadane pytanie wprawdzie nie rozróżniło typów znajomości. Należy bowiem przyjąć, że w Internecie mamy do czynienia z różnym charakterem zawieranych znajomości. Są osoby, które poznajemy na portalach społecznościowych, na forach tematycznych, w pokojach dyskusji (chat room). Możemy zdobyć o nich dość sporo informacji prawdziwych bądź fałszywych. Toteż nie brakuje znajomości wykorzystywanych tylko do rywalizacji w grach online o minimalnym charakterze wiedzy na temat rywala. Należy zatem przyjąć, że wśród 33,87\% zawieranych przez uczniów w Internecie znajomości nie wszystkie muszą budzić nasz niepokój.

Tabela 12. Z których z wymienionych aplikacji korzystasz?

\begin{tabular}{|l|c|}
\hline \multicolumn{1}{|c|}{ Wybór odpowiedzi } & Wynik procentowy \\
\hline Facebook & $54,84 \%$ \\
\hline Instagram & $32,26 \%$ \\
\hline Snapchat & $40,32 \%$ \\
\hline Musical.ly & $40,32 \%$ \\
\hline YouTube & $87,10 \%$ \\
\hline Sarahah & $12,90 \%$ \\
\hline Inne & $38,71 \%$ \\
\hline
\end{tabular}

Uczniowie najczęściej korzystają z takich aplikacji, jak: YouTube $(87,1 \%)$, Facebook (54,84\%), Snapchat (40,32\%), Musical.ly (40,32\%), Instagram (32,26\%). Najrzadziej wykorzystywaną aplikacją okazało się Sarahah (12,9\%). Należy zatem stwierdzić, że filmiki zamieszczane na YouTube cieszą się największą oglądalnością wśród badanych uczniów.

Równolegle do ankiety skierowanej do uczniów 11 pytań ewaluacyjnych zadano również rodzicom dzieci. Ich celem była weryfikacja odpowiedzi uczniowskich, uzyskanie informacji co do stanu świadomości rodziców na temat niebezpieczeństwa korzystania z Internetu przez dzieci i znajomość celów wychowawczych propagowanych przez szkołę. Wyniki przedstawiały się następująco:

Tabela 13. Ile godzin spędza Państwa dziecko, korzystając z Internetu (komputer, komórka, tablet itp.)?

\begin{tabular}{|l|c|}
\hline \multicolumn{1}{|c|}{ Liczba godzin } & Wynik procentowy \\
\hline $0-2$ & $58,97 \%$ \\
\hline $2-4$ & $25,64 \%$ \\
\hline 4 i więcej & $12,82 \%$ \\
\hline Wcale & $2,56 \%$ \\
\hline
\end{tabular}


Rodzice stwierdzili, że dzieci najczęściej korzystają z Internetu w przedziale 0-2 godzin dziennie. Odpowiedź ta potwierdziła wynik uzyskany od uczniów. Zdaniem rodziców, 25,64\% uczniów poświęca sieci od 2 do 4 godzin, 12,82\% - 4 i więcej godzin, a 2,56\% wcale nie korzysta z Internetu. Wyniki uzyskane od rodziców w zasadniczej mierze pokrywają się z odpowiedziami uczniowskimi na ten sam temat.

Tabela 14. Ile godzin Państwa dziecko spędza, korzystając z mediów społecznościowych?

\begin{tabular}{|l|c|}
\hline \multicolumn{1}{|c|}{ Liczba godzin } & Wynik procentowy \\
\hline $0-2$ & $66,67 \%$ \\
\hline $2-4$ & $23,08 \%$ \\
\hline 4 i więcej & $5,13 \%$ \\
\hline Wcale & $5,13 \%$ \\
\hline
\end{tabular}

Zdaniem rodziców kontakt ich dzieci z mediami społecznościowymi mieści się w przedziale od 0 do 2 godzin dziennie. Tego zdania jest aż 66,67\% badanych rodziców. Natomiast $23,08 \%$ rodziców uważa, że ich dzieci korzystają z mediów społecznościowych od 2 do 4 godzin dziennie; powyżej 4 godzin zadeklarowało 2 rodziców, co stanowi 5,13\%. Tyle samo odpowiedziało, że ich dzieci wcale nie korzystają z portali społecznościowych. Większość rodziców jest przekonana, że media społecznościowe w życiu ich dzieci zajmują przedział 0-2 godzin dziennie. Trudno określić, czy do tego szacunku rodzice uwzględniają również czas ich dzieci spędzony w sieci poza domem (w drodze do szkoły i z powrotem oraz podczas przerw lekcyjnych).

Tabela 15. lle lat trzeba mieć, aby móc korzystać z Facebooka?

\begin{tabular}{|l|c|}
\hline \multicolumn{1}{|c|}{ Wiek } & Wynik procentowy \\
\hline 10 & $0,00 \%$ \\
\hline 13 & $64,10 \%$ \\
\hline 15 & $17,95 \%$ \\
\hline Nie wiem & $17,95 \%$ \\
\hline
\end{tabular}

Również większość rodziców poprawnie odpowiedziała na pytanie dotyczące wieku użytkownika Facebooka (64,1\%). Natomiast 17,95\% rodziców uznała, że wymagany wiek to 15 lat, i tyle samo rodziców nie znało odpowiedzi na to pytanie.

Tabela 16. Czy w jakikolwiek sposób monitorują Państwo działania dziecka w Internecie?

\begin{tabular}{|l|c|}
\hline Wybór odpowiedzi & Wynik procentowy \\
\hline Tak & $89,74 \%$ \\
\hline Nie & $10,26 \%$ \\
\hline
\end{tabular}


Dość dużym zaskoczeniem okazała się odpowiedź rodziców na pytanie: „Czy w jakikolwiek sposób monitorują Państwo działania dziecka w Internecie?”. Aż 89,74\% ankietowanych odpowiedziało pozytywnie na treść zadanego pytania. Tylko 10,26\% nie monitoruje działań swoich dzieci w Internecie. Uzyskana odpowiedź nie pokrywa się z wynikiem badań przeprowadzonych wśród uczniów. Przypomnijmy, że 50\% uczniów stwierdziło, że rodzice nie mają wpływu na publikowane przez nich treści w Internecie.

Tabela 17. Czy ustalili Państwo z dziećmi zasady korzystania z Internetu (pory, strony, aplikacje)?

\begin{tabular}{|c|c|}
\hline Wybór odpowiedzi & Wynik procentowy \\
\hline Tak & $82,76 \%$ \\
\hline Nie & $17,24 \%$ \\
\hline
\end{tabular}

Podobna rozbieżność opinii występuje w pytaniu o ustalenie zasad korzystania z Internetu. Aż 82,76\% rodziców uważa, że zasady takie zostały ustalone, i tylko $17,24 \%$ rodziców jest odmiennego zdania. W podobnym pytaniu zadanym uczniom aż 45,16\% respondentów stwierdziło, że zasady korzystania z Internetu nigdy z rodzicami nie zostały ustalone.

Tabela 18. Które z wymienionych aplikacji Państwo znają?

\begin{tabular}{|l|c|}
\hline \multicolumn{1}{|c|}{ Wybór odpowiedzi } & Wynik procentowy \\
\hline Facebook & $100,00 \%$ \\
\hline Instagram & $72,41 \%$ \\
\hline Snapchat & $58,62 \%$ \\
\hline Musical.ly & $27,59 \%$ \\
\hline YouTube & $96,55 \%$ \\
\hline Sarahah & $0,00 \%$ \\
\hline Inne & $17,24 \%$ \\
\hline
\end{tabular}

Wszyscy rodzice znają aplikację Facebook, 96,55\% ankietowanych zna YouTube, $72,41 \%$ wie, czym jest Instagram. Kolejną popularną aplikacją jest Snapchat (58,62\%). Stosunkowo mniej znaną dla tej grupy społecznej okazała się aplikacja Musical.ly (27,59\%). Natomiast nikt z rodziców nie zna aplikacji Sarahah, a 17,24\% zna inne aplikacje, niewymienione $\mathrm{w}$ ankiecie. 
Tabela 19. Czy orientują się Państwo, jakiego typu informacje zamieszczają Państwa dzieci w Internecie?

\begin{tabular}{|l|c|}
\hline \multicolumn{1}{|c|}{ Wybór odpowiedzi } & Wynik procentowy \\
\hline Zainteresowania & $65,52 \%$ \\
\hline Wydarzenia, imprezy, wyjścia & $34,48 \%$ \\
\hline Szkoła & $17,24 \%$ \\
\hline Życie prywatne & $20,69 \%$ \\
\hline Wakacje & $20,69 \%$ \\
\hline
\end{tabular}

Z informacji uzyskanych od uczniów dowiedzieliśmy się, że 50\% rodziców ma wpływ na to, jakie treści są publikowane przez ich dzieci w Internecie. 65,52\% rodziców uważa, że publikacji podlegają treści związane z zainteresowaniami dzieci, 34,48\% uważa, że są to informacje o wydarzeniach, imprezach lub wyjściach, 20,69\% - o życiu prywatnym i o wakacjach, natomiast najmniej rodziców (17,24\%) uważa, że publikowane przez ich dzieci treści dotyczą życia szkolnego.

Tabela 20. Jak często rozmawiają Państwo z dziećmi o ich aktywności w Internecie?

\begin{tabular}{|l|c|}
\hline \multicolumn{1}{|c|}{ Wybór odpowiedzi } & Wynik procentowy \\
\hline Bardzo często & $48,72 \%$ \\
\hline Często & $23,08 \%$ \\
\hline Od czasu do czasu & $23,08 \%$ \\
\hline Rzadko & $5,13 \%$ \\
\hline Nigdy & $0,00 \%$ \\
\hline
\end{tabular}

Kolejne pytanie ankietowe dotyczyło rozmowy rodziców i dzieci na temat działań podejmowanych przez ich pociechy. Najliczniejszą grupą w tej statystyce okazali się rodzice, którzy „bardzo często” rozmawiają z dziećmi o tym, co robią w Internecie $(48,72 \%)$. Kolejną grupą byli rodzice, którzy rozmawiają „często” (23,08\%), i taki sam odsetek „od czasu do czasu” (23,08\%). Tylko 5,13\% respondowanych rodziców stwierdziło, że „rzadko” rozmawia na ten temat ze swoimi dziećmi. Wśród ankietowanych nie było nikogo, kto „nigdy” nie rozmawiałby na temat aktywności podejmowanej przez swoje dzieci w Internecie.

Tabela 21. Czy dziecko zawiera nowe znajomości przez Internet?

\begin{tabular}{|l|c|}
\hline \multicolumn{1}{|c|}{ Wybór odpowiedzi } & Wynik procentowy \\
\hline Tak & $24,14 \%$ \\
\hline Nie & $65,52 \%$ \\
\hline Nie wiem & $10,34 \%$ \\
\hline
\end{tabular}


Na pytanie o możliwość zawierania przez dzieci internetowych znajomości większość rodziców $(65,52 \%)$ odpowiedziała negatywnie. $24,14 \%$ rodziców uważa, że dzieci nawiązują takie znajomości, a 10,34\% rodziców nie posiadało wiedzy na ten temat. Podobny odsetek rodziców i dzieci twierdzi, że nie nawiązują nowych znajomości przez Internet.

Tabela 22. Czy dziecko, korzystając z Internetu, głównie gra, czy zabawa połączona jest również z edukacją (np. portale edukacyjne)?

\begin{tabular}{|l|c|}
\hline \multicolumn{1}{|c|}{ Wybór odpowiedzi } & Wynik procentowy \\
\hline Tylko gra & $10,34 \%$ \\
\hline Gra i korzysta z portali edukacyjnych & $68,97 \%$ \\
\hline Tylko korzysta z portali edukacyjnych & $20,69 \%$ \\
\hline
\end{tabular}

Podobnie jak w przypadku odpowiedzi uczniów na rodzaj podejmowanej w Internecie aktywności, najwięcej rodziców $(68,97 \%)$ twierdzi, że ich pociechy grają online oraz korzystają z portali edukacyjnych. 20,69\% uważa, że dzieci korzystają z Internetu tylko w celach edukacyjnych, a 10,34\% rodziców wskazuje na podejmowane przez ich dzieci funkcje rozrywkowe.

Ostatnią grupą, do której skierowano ankietę ewaluacyjną, byli nauczyciele. Na pytania ankietowe odpowiadało 20 nauczycieli z różnych przedmiotów, przeważnie byli to wychowawcy klas. Zadane pytania miały sprawdzić stopień wrażliwości nauczycielskiej w kontekście niebezpiecznego korzystania przez dzieci z Internetu. Oto uzyskane wyniki:

Tabela 23. Ile lat trzeba mieć, aby móc korzystać z Facebooka?

\begin{tabular}{|l|c|}
\hline \multicolumn{1}{|c|}{ Wiek } & Wynik procentowy \\
\hline 10 & $5 \%$ \\
\hline 13 & $50 \%$ \\
\hline 15 & $25 \%$ \\
\hline Nie wiem & $20 \%$ \\
\hline
\end{tabular}

Zaledwie połowa nauczycieli znała prawidłową odpowiedź na zadane pytanie o wiek użytkownika Facebooka. Sporą grupą byli nauczyciele (25\%), którzy uważali, że korzystać z Facebooka można dopiero od 15. roku życia, lub tacy, którzy nie znali odpowiedzi na to pytanie (20\%). 5\% ankietowanych stwierdziło, że z portalu można korzystać już od 10. roku życia. Sami uczniowie i rodzice wydają się bardziej zorientowani w tej materii. 
Tabela 24. Czy w jakikolwiek sposób ukierunkowują Państwo działania uczniów w Internecie (sposób zdobywania wiedzy i krytyczne podejście do źródeł)?

\begin{tabular}{|l|c|}
\hline Wybór odpowiedzi & Wynik procentowy \\
\hline Tak & $100 \%$ \\
\hline Nie & $0 \%$ \\
\hline
\end{tabular}

Na pytanie dotyczące instruowania uczniów przez nauczycieli co do zasad bezpiecznego korzystania z Internetu wszyscy stwierdzili, że podejmują takie działania.

Tabela 25. Czy mają Państwo wgląd do zdjęć, które uczniowie zamieszczają w Internecie?

\begin{tabular}{|l|c|}
\hline Wybór odpowiedzi & Wynik procentowy \\
\hline Tak & $60 \%$ \\
\hline Nie & $40 \%$ \\
\hline
\end{tabular}

60\% nauczycieli stwierdziło, że ma wgląd do zdjęć, które uczniowie zamieszczają w Internecie, natomiast 40\% respondowanych takich możliwości nie posiada.

Tabela 26. Które z wymienionych aplikacji Państwo znają?

\begin{tabular}{|l|c|}
\hline \multicolumn{1}{|c|}{ Wybór odpowiedzi } & Wynik procentowy \\
\hline Facebook & $90 \%$ \\
\hline Instagram & $75 \%$ \\
\hline Snapchat & $55 \%$ \\
\hline Musical.ly & $30 \%$ \\
\hline YouTube & $100 \%$ \\
\hline Sarahah & $10 \%$ \\
\hline Inne & $20 \%$ \\
\hline
\end{tabular}

Nauczyciele wykazali się znajomością takich aplikacji, jak: YouTube (100\%), Facebook (90\%), Instagram (75\%), Snapchat (55\%), Musical.ly (30\%), Sarahah (10\%) oraz innych (20\%).

Tabela 27. Jak często rozmawiają Państwo z uczniami o ich aktywności w Internecie?

\begin{tabular}{|l|c|}
\hline \multicolumn{1}{|c|}{ Wybór odpowiedzi } & Wynik procentowy \\
\hline Bardzo często & $15 \%$ \\
\hline Często & $30 \%$ \\
\hline Od czasu do czasu & $40 \%$ \\
\hline Rzadko & $15 \%$ \\
\hline Nigdy & $0 \%$ \\
\hline
\end{tabular}


40\% nauczycieli rozmawia „od czasu do czasu” z uczniami o tym, co robią w Internecie. Drugie miejsce zajęli nauczyciele, którzy te tematy poruszają z uczniami „często” (30\%). Natomiast 15\% nauczycieli rozmawia ze swoimi wychowankami o działaniach podejmowanych w Internecie „bardzo często” lub „rzadko”. Nie ma ani jednego nauczyciela, który „nigdy” nie rozmawia z uczniami na ten temat.

Tabela 28. Czy orientują się Państwo, jakiego typu informacje zamieszczają uczniowie w Internecie?

\begin{tabular}{|l|c|}
\hline Wybór odpowiedzi & Wynik procentowy \\
\hline Tak & $55 \%$ \\
\hline Nie & $45 \%$ \\
\hline
\end{tabular}

Duża część nauczycieli (45\%) nie orientuje się, jakiego typu informacje zamieszczają uczniowie w Internecie, jednak 55\% posiada taką wiedzę. Sytuacja taka wcale nie musi wynikać z faktu braku zainteresowania wychowawczego nauczycieli, ale może świadczyć o technicznych ograniczeniach programów i aplikacji wykorzystywanych w sieci.

Tabela 29. Czy reagują Państwo na przejawy cyberprzemocy?

\begin{tabular}{|l|c|}
\hline Wybór odpowiedzi & Wynik procentowy \\
\hline Tak & $95 \%$ \\
\hline Nie & $5 \%$ \\
\hline
\end{tabular}

95\% nauczycieli reaguje na przejawy cyberprzemocy. Jeden nauczyciel (5\%) nie podejmuje właściwego działania.

Tabela 30. Czy zgłaszacie Państwo przełożonym, jakie strony internetowe powinny być zablokowane w szkolnej pracowni komputerowej?

\begin{tabular}{|c|c|}
\hline Wybór odpowiedzi & Wynik procentowy \\
\hline Tak & $45 \%$ \\
\hline Nie & $55 \%$ \\
\hline
\end{tabular}

Większość nauczycieli (55\%) nie zgłasza opiekunowi pracowni informatycznej adresów stron, które powinny być dla uczniów zablokowane. Tylko 45\% ankietowanych podejmuje odpowiednie kroki w tym zakresie. 
Tabela 31. Czy konsultują Państwo swoje obserwacje dotyczące działań ucznia w Internecie z rodzicami wychowanka?

\begin{tabular}{|l|c|}
\hline Wybór odpowiedzi & Wynik procentowy \\
\hline Tak & $85 \%$ \\
\hline Nie & $15 \%$ \\
\hline
\end{tabular}

Zdecydowana większość nauczycieli (85\%) konsultuje swoje obserwacje dotyczące działań ucznia w Internecie z rodzicami wychowanka. Tylko 15\% respondowanych nie podejmuje współpracy z rodzicami na tym polu.

Tabela 32. Czy wykorzystują Państwo Internet do kontaktów z rodzicami?

\begin{tabular}{|c|c|}
\hline Wybór odpowiedzi & Wynik procentowy \\
\hline Tak & $80 \%$ \\
\hline Nie & $20 \%$ \\
\hline
\end{tabular}

$80 \%$ nauczycieli wykorzystuje Internet do kontaktu z rodzicami, natomiast $20 \%$ nie komunikuje się z rodzicami w taki sposób.

\section{Wnioski końcowe}

Analizowane badanie ankietowe zostało przeprowadzone za pomocą narzędzia SurveyMonkey. Zarówno uczniowie, jak i rodzicie wraz z nauczycielami udzielali odpowiedzi na pytania ankietowe w środowisku domowym w formie online. Takie środowisko miało za zadanie wprowadzać jak najmniej stresującą atmosferę oraz pozostawić więcej czasu na przemyślaną odpowiedź.

Wyniki badawcze sugerują, że stajemy się społeczeństwem coraz częściej korzystającym z nowoczesnych technologii i wykorzystującym dostępne narzędzia internetowe. Sami uczniowie poruszają się sprawnie w przestrzeni wirtualnej.

Badanie ewaluacyjne wykazało, że w Katolickiej Szkole Podstawowej im. Piotra Dunina w Chojnicach:

- uczniowie dość bezpiecznie korzystają z mediów społecznościowych;

- szkolna pracowania jest dobrze zabezpieczona przed wchodzeniem na strony zawierające treści niebezpieczne dla uczniów;

- w procesie dydaktycznym Internet jest jednym ze źródeł pozyskiwania informacji niezbędnych do poszerzenia wiedzy;

- uczy się bezpiecznego korzystania z Internetu i posługiwania się mediami społecznościowymi;

- są podejmowane działania wychowawcze o charakterze personalistycznym, zgodne z programem wychowawczo-profilaktycznym w kontekście bezpiecznego korzystania $z$ Internetu. 
$\mathrm{Na}$ podstawie przeprowadzonych badań wykazano zbieżność odpowiedzi uczniów i rodziców w zakresie czasu korzystania z Internetu. Ponad 46\% uczniów spędza przed komputerem w trybie online od 0 do 2 godzin dziennie, a 36\% uczniów w tym przedziale poświęca swój czas na korzystanie z mediów społecznościowych. Najbardziej znanymi aplikacjami wykorzystywanymi przez uczniów są: Facebook i YouTube. Niepokoi jednak fakt, że około 24\% uczniów korzysta z portali społecznościowych od 2 do 4 godzin dzienne, a $21 \%$ powyżej 4 godzin, co oznacza, że prawie połowa uczniów spędza w wirtualnej przestrzeni powyżej 3 godzin dzienne. Korzystanie tylko z portalów społecznościowych pozbawione jest elementu edukacyjnego, ściśle związanego ze zdobywaniem wiedzy z konkretnego przedmiotu.

Ilość wolnego czasu spędzanego przez uczniów w Internecie i poświęcanego na aktywność edukacyjną, relaksacyjną czy rozrywkową jest dość duża. Przy tak wzmożonej aktywności w sieci brakuje zwykle czasu na naturalne procesy wychowawcze działające w środowisku rodzinnym. Komputer i przywiązanie do niego nie sprzyjają pogłębianiu więzi rodzinnych przejawiających się w kontaktach interpersonalnych oraz wspólnotowych działaniach dążących do prawidłowego rozwoju osobowości dziecka. $\mathrm{Na}$ ten problem zwraca uwage program wychowawczo-profilaktyczny szkoły. Szkoła, świadoma istniejących w sieci zagrożeń, proponuje wiele zajęć i aktywności projektowych służących ograniczeniu korzystania z Internetu poprzez organizację wydarzeń o charakterze kulturalno-towarzyskim: dyskoteki, bale, święto rodziny, dzień sportu, dzień babci i dziadka, dzień św. Franciszka, dyskusyjny klub filmowy itp.

Zbliżona grupa rodziców i uczniów stwierdziła, że Internet i dostępne aplikacje są wykorzystywane do gry i nauki. W przypadku uczniów było to $46 \%$ respondowanych, a w przypadku rodziców - 69\%.

Uczniowie czują się bezpiecznie, korzystając z Internetu, zarówno w domu, jak i w szkole. Zdecydowana większość stwierdziła, że w szkolnej pracowni komputerowej nie można wchodzić na wszystkie strony. Istnieje katalog stron zabronionych i zablokowanych. W przeważającej mierze (66\%) uczniowie nie nawiązują nowych znajomości przez Internet, jednak w przypadku 34\% sytuacja taka miała miejsce. Okazuje się, że rodzice nie są do końca świadomi tego faktu. Tylko $24 \%$ rodziców uważa, że może dochodzić do wirtualnych znajomości, natomiast prawie $66 \%$ jest odmiennego zdania, a ponad $10 \%$ nie ma na ten temat wiedzy. Widać w tym względzie dość dużą rozbieżność pomiędzy opiniami uczniów i rodziców. Fakt rodzicielskiej nieświadomości może narazić na niebezpieczeństwo dzieci nieodpowiednio korzystające z sieci, choć tak jak wspomnieliśmy, nie każda wirtualna znajomość jest zagrożeniem.

Choć wyniki dotyczące stosowania środków bezpieczeństwa w sieci potwierdzają odpowiedzi uczniów, rodziców i nauczycieli, brak świadomości rodziców co do zakresu aktywności dzieci w Internecie może być przyczyną ich narażenia na niebezpieczeństwo. Z tego też względu ważną rolę w kwestii bezpiecznego korzystania z Internetu odgrywają nauczyciele w 100\% rozmawiający z uczniami o zagrożeniach w sieci (choć z różną częstotliwością). Prawie połowa ankietowanych nauczycieli zgłasza su- 
gestie dotyczące niebezpiecznych stron internetowych opiekunowi szkolnej pracowni komputerowej.

Rozbieżności w odpowiedziach uczniów i rodziców występują w pytaniach dotyczących komunikacji - ustalania zasad korzystania z Internetu i z mediów społecznościowych. Aż 90\% ankietowanych rodziców odpowiedziało, że do takich ustaleń doszło, tymczasem tylko 50\% uczniów potwierdziło ten fakt. Podobnie w kwestii publikowania w Internecie różnych treści i ich monitowania: prawie 90\% rodziców uważa, że monituje regularnie działania swoich dzieci w Internecie, natomiast tylko $50 \%$ uczniów potwierdza taki stan rzeczy. W tym przypadku nasuwa się jeden wniosek - uczniowie mają świadomość, jaką wiedzę na temat Internetu i mediów społecznościowych posiadają ich rodzice, i aby umieścić w Internecie treści, o których rodzice nie mają się dowiedzieć, wykorzystują inne, nieznane rodzicom aplikacje (na przykład żadnemu z rodziców nie jest znana aplikacja Sarahah).

Około 48\% rodziców twierdzi, że „bardzo często” rozmawia ze swoimi dziećmi o korzystaniu z Internetu, ale innego zdania są uczniowie. Tylko 8\% uczniów stwierdziło, że rodzice rozmawiają z nimi „bardzo często” o bezpiecznym korzystaniu z zasobów sieci. Największa grupa, bo 30\% uczniów, stwierdziła, że rodzice rozmawiają z nimi o Internecie tylko „od czasu do czasu”.

Nauczyciele interesują się działaniami uczniów w sieci. Spora grupa nauczycieli wie, jakie treści uczniowie zamieszczają w Internecie, co świadczy o dużym zaufaniu, jakim uczniowie darzą swoich nauczycieli. Najprawdopodobniej jest ro relacja wychowawca-uczeń. Nauczyciele wykorzystują również Internet do kontaktów z rodzicami i konsultują z nimi swoje obserwacje na temat działań ucznia w Internecie (szczególnie w kontekście ewentualnych zagrożeń). Nauczyciele rozmawiają z uczniami o ich działaniach w Internecie i ukierunkowują ich działania w taki sposób, aby zagwarantować im bezpieczeństwo w sieci.

Wyniki badań wskazały na konieczność podjęcia odpowiednich kroków w placówce edukacyjnej w celu zagwarantowania większego poczucia bezpieczeństwa w sieci podczas korzystania $\mathrm{z}$ Internetu i mediów społecznościowych. W pierwszej kolejności zorganizowano spotkanie dla rodziców dzieci uczących się w szkole, które poprowadził psycholog i pedagog szkolny. Edukowano rodziców co do zasadności limitowania czasu spędzonego przez dzieci w Internecie. Szkoleniowcy zwrócili uwagę na fakt, że jest to rzecz niezwykle trudna do zrealizowania i powinna zostać zrekompensowana inną aktywnością rodzinną. Psycholog zasugerował, aby więcej czasu spędzać w gronie rodzinnym, na basenie, wycieczce, muzeum, koncercie. Dziecko nie może odnieść wrażenia, że zabrano mu czas poświęcony na rekreację w sieci i zastąpiono go tradycyjnie rozumianą nauką.

Psycholog szkolny podjął się również przeprowadzenia kursu dla rodziców uświadamiającego zagrożenia płynące z sieci. Okazuje się, że spora część rodziców nie była świadoma niebezpieczeństw czyhających na dzieci w Internecie. Wskazano na częste przypadki cyberbullyingu i innych nękań psychicznych. Zarekomendowa- 
no rodzicom rozmowę z dziećmi na temat Internetu, korzyści i wad płynących z jego korzystania oraz systematyczne kontrole mające na celu profilaktyczne podejście do sytuacji niepożądanych.

Szkoła postanowiła jeszcze lepiej zabezpieczyć szkolną pracownię komputerową przed wchodzeniem przez uczniów na strony niebezpieczne oraz poszerzyć tematykę godzin wychowawczych o tematy związane z zagrożeniem płynącym z sieci. Wychowawcy mieliby zostać w tym zakresie odpowiednio przeszkoleni. Dwa razy do roku w szkole ma być przeprowadzana anonimowa ankieta dostarczająca informacji o zjawiskach niepokojących i możliwości wczesnego ich wyeliminowania z życia uczniów.

Choć przeprowadzone wyniki badań i ich analiza dotyczą tylko uczniów, rodziców i nauczycieli jednej z pomorskich szkół, nie można wykluczyć, że badania te znajdą swoje potwierdzenie w znacznie szerszym środowisku szkolnym. Tendencja i powszechność korzystania z Internetu jest reprezentatywna we wszystkich szkołach. Jadnak w przypadku Katolickiej Szkoły Podstawowej im. Piotra Dunina w Chojnicach istotnym czynnikiem wpływającym na poczucie bezpiecznego korzystania z Internetu i określenia pewnych granic etycznych może być aspekt wychowawczy skoncentrowany wokół personalistycznej wizji wychowania. Nie można zanegować faktu, że aspekt wychowania do odpowiedzialnego korzystania z Internetu poprzez ukazanie integralnego wymiaru osoby ludzkiej nie pozostaje bez znaczenia w szeroko pojętym procesie wychowawczym uczniów tej szkoły. Wywiad antropologiczny pokazał, że rodzice znają program wychowawczo-profilaktyczny szkoły, a zapisując do niej swoje dziecko, wyrażają zgodę na jego realizację poprzez skoordynowane działania między innymi wychowawców i rodziców. Ankieta pokazała, że zarówno rodzice, jak i nauczyciele są świadomi związku pomiędzy sukcesem wychowawczym a korzystaniem z Internetu. Twierdzą oni zgodnie, że Internet może być zarazem źródłem destruktywnych zachowań wychowawczych, jak i nieoszacowaną pomocą w procesie kształtowania osobowości młodego pokolenia. Organizacji poprawnego procesu wychowawczego sprzyjać będzie bezpieczne korzystanie z Internetu poprzez kontrolę i ograniczenia jego użycia. Rodzice w większości przypadków stwierdzili, że Katolicka Szkoła Podstawowa im. Piotra Dunina w Chojnicach stara się w procesie edukacji nie zapomnieć o uczniu w kontekście jego niepowtarzalności i godności. Dbałość o integralne wychowanie (również wobec współczesnych wyzwań technicznych) wypływa ze świadomości wychowawców i całego środowiska szkolnego. Wychowanie do odpowiedzialnego korzystania z Internetu stanowić powinno ważny element procesu wychowawczego każdej placówki edukacyjnej. Są to zadania aktualne i pilne, szczególnie w dobie nawarstwiających się wychowawczych problemów społeczeństw wielokulturowych i perspektywy mieszania się narodów obcych kulturowo. 


\section{Bibliografia}

Aftab P., Internet a dzieci. Uzależnienia i inne niebezpieczeństwa, Wydawnictwo Prószyński i S-ka, Warszawa 2003.

Anderson J., Wilkins R., Żegnaj telewizorku. Jak nauczyć swoja rodzinę rozsądnie korzystać z telewizora, gier komputerowych i Internetu, Adamantan, Warszawa 2000.

Bednarek J., Lubina E., Kształcenie na odległość. Podstawy dydaktyki, Wydawnictwo Naukowe PWN, Warszawa 2008.

Bendyk E., Komputer ogłupia, „Polityka”, nr 34/2010.

Biała J., Zagrożenia $w$ wychowaniu dziecka we współczesnej rodzinie polskiej, Wydawnictwo Akademii Świętokrzyskiej, Kielce 2006.

Castells M., Galaktyka Internetu. Refleksje nad Internetem, biznesem i społeczeństwem, Rebis, Poznań 2003.

Chudy W., Pedagogika godności. Elementy etyki pedagogicznej, Wydawnictwo TN KUL, Lublin 2009.

Cichoń W., Aksjologiczne ujęcie procesu wychowania, [w:] F. Adamski (red.), Człowiek - wychowanie - kultura, WAM, Kraków 1993.

Gajda J., Kulturotwórcze i edukacyjne funkcje mass mediów, [w:] W. Strykowski (red.), Media a edukacja, Wydawnictwo eMPi2, Poznań 2000.

Gawlina Z., Ścisłowicz S. (red.), Pedagogika wobec aktualnych problemów społecznych, Wydawnictwo Wyższej Szkoły Biznesu i Przedsiębiorczości, Ostrowiec Świętokrzyski 2002.

Grzenia J., Komunikacja językowa w Internecie, Wydawnictwo Naukowe PWN, Warszawa 2006.

Kossowski P., Dziecko i reklama telewizyjna, Żak, Warszawa 1999.

Merton T., Nikt nie jest samotna wyspa, Zysk i S-ka, Poznań 2008.

Moczydłowska I., Uzależnienia od komputera i Internetu, „Problemy Opiekuńczo-Wychowawcze", nr 4/1999.

Noga H., Wychowawcze aspekty „rewolucji informatycznej”, Wydawnictwo Naukowe Akademii Pedagogicznej, Kraków 2008.

Siemieniecki B.F., Lewandowski W., Internet w szkole, Wydawnictwo Adam Marszałek, Toruń 2000.

Sokołowski M. (red.), Oblicza Internetu. Internet a globalne społeczeństwo informacyjne, Algraf, Elbląg 2005.

Strykowski W. (red.), Media a edukacja, Wydawnictwo eMPi2, Poznań 2000.

Sujak E., Rozważania o ludzkim rozwoju, Znak, Kraków 1998.

Szudra A., Uzar K. (red.), Personalistyczny wymiar filozofii wychowania, Wydawnictwo KUL, Lublin 2009.

Szymańska M., Rola Internetu w procesie edukacji dzieci i młodzieży, „Problemy Opiekuńczo-Wychowawcze", nr 6/2008. 
Wawrzyk-Chodaczek M., Kształcenie kultury audiowizualnej młodzieży, Wydawnictwo Uniwersytetu Wrocławskiego, Wrocław 2000.

Wojtasik Ł., Rodzice wobec zagrożeń dzieci w Internecie, „Dziecko Krzywdzone”, nr $1 / 2009$.

\title{
Internet and education - based on the Piotr Dunin Catholic Primary School in Chojnice
}

\begin{abstract}
This article discusses how the Internet influences a person's upbringing. It is based on a study carried out at the Piotr Dunin Catholic Primary School in Chojnice. The study investigated how safely students use the Internet and social media, the potential impact on upbringing and whether the school carries out work aimed at the personal development of students. The study showed that the amount of time spent at the computer does affect the pedagogical process. Parents and teachers are aware of this and they take appropriate steps in harmony with the school's educational and preventive program. Although the amount of time students from this school spend online is not alarming, the parents and the school take appropriate measures to control and limit the use of the Internet as it is an instrument that disturbs personalistic upbringing.
\end{abstract}

Keywords: Internet and education, online safety, personal education

\begin{abstract}
About the author: Rafał Maliszewski - PhD, philosopher, educator, linguist, Kashubologist; graduated from the John Paul II Catholic University of Lublin and the Philosophy College in Munich. Doctorat study in sociolinguistics at the Institute of German Philology at the University of Gdansk.
\end{abstract}




\title{
Edukacja medialna „pokolenia kciuka” - błahostka czy obowiązek?
}

DOI: 10.25312/2083-2923.15/2019_11rm

\begin{abstract}
Streszczenie: Dorośli często uważają, że korzystanie z mediów, zwłaszcza z Internetu, i coraz bardziej zaawansowanych urządzeń multimedialnych jest dla nich czymś nowym, z czym nie zawsze umieją sobie sprawnie poradzić. Osobami, których najczęściej pytają o efektywne korzystanie z zasobów medialnych, są ich dzieci, gdyż to właśnie one są nazywane "pokoleniem kciuka” z racji tego, że spędzają najwięcej czasu na użytkowaniu mediów. Wśród społeczeństwa rodzi się pogląd mówiący o tym, że to właśnie dzieci i młodzież są specjalistami od korzystania z sieci czy urządzeń o coraz bardziej zaawansowanych możliwościach. Mając na uwadze tę opinię, należy zadać pytanie o zasadność realizowania edukacji multimedialnej wśród ludzi, którzy po wirtualnym świecie poruszają się często sprawniej niż po chodniku. W niniejszym artykule scharakteryzowano rolę edukacji w życiu człowieka, omówiono efekty edukacji medialnej, a następnie skonfrontowano je z niebezpieczeństwami, jakie niesie za sobą nieświadome korzystanie $\mathrm{z}$ mediów.
\end{abstract}

Słowa kluczowe: edukacja medialna, pokolenie kciuka, kompetencje medialne, media

\section{Wstęp}

W niniejszym artykule poruszono zagadnienie współcześnie nader ważne, koncentrując się na edukacji medialnej wśród dzieci i młodzieży, których nieprzypadkowo coraz częściej nazywa się przedstawicielami „pokolenia kciuka”. Myśl zawarta w tytule artykułu skłania nas do zastanowienia się nad pytaniem, czy jest potrzeba edukowa-

* Renata Matusiak - doktor nauk społecznych w dyscyplinie pedagogiki, magister socjologii Katolickiego Uniwersytetu Lubelskiego Jana Pawła II. W ramach zainteresowań odbyła studia na kierunkach: profilaktyka społeczna i terapia uzależnień, kryminologia, przygotowanie pedagogiczne. Organizatorka i uczestniczka licznych konferencji naukowych międzynarodowych i ogólnopolskich, redaktor prac zbiorowych, autorka artykułów naukowych. Zainteresowania naukowe: edukacja medialna, nowe media, cyberprzestępczość, bezpieczeństwo w sieci. 
nia medialnego dzieci, które od najmłodszych lat korzystają z mediów i wydawać by się mogło, że znają się na nich lepiej niż część dorosłych. Celem podjęcia tej tematyki było obalenie mitu mówiącego, iż dzieci i młodzież poruszają się w świecie mediów na tyle sprawnie, że edukacja medialna nie stanowi dla nich konieczności. W znalezieniu odpowiedzi na postawione pytanie pomocne okazało się przypomnienie roli, jaką odgrywa edukacja w życiu człowieka, oraz zaakcentowanie związków występujących pomiędzy edukacją medialną a przygotowaniem do funkcjonowania we współczesnym świecie. Wyjaśnienie terminu „pokolenie kciuka” również przyczyniło się do opowiedzenia się za koniecznością realizowania edukacji medialnej wśród dzieci i młodzieży.

\section{Rola edukacji w życiu człowieka}

Edukacja rozumiana potocznie kojarzy się nam z nauką szkolną trwającą wiele lat. W ujęciu naukowym oznacza natomiast:

Ogół wpływów na jednostki i grupy ludzkie, sprzyjających takiemu ich rozwojowi, aby w najwyższym stopniu stały się one świadomymi i twórczymi członkami wspólnoty społecznej, kulturowej i narodowej oraz były zdolne do aktywnej samorealizacji własnej tożsamości i własnego JA poprzez podejmowanie zadań ponadosobistych [...] to prowadzenie drugiego człowieka ku wyższym poziomom rozwojowym i jego własna aktywność w osiąganiu pełnych i swoistych dlań możliwości. To ogół czynności i procesów sprzyjających rozwojowi oraz stan ich efektów, czyli osiągnięty poziom kompetencji, tożsamości i podmiotowości ${ }^{1}$.

Definicja ta, proponowana przez Z. Kwiecińskiego, ukazuje nam rolę, jaką odgrywa proces edukacji w życiu człowieka. Dzięki realizowaniu tego procesu możliwe jest tworzenie społeczeństwa i kultury, a także budowanie własnej tożsamości.

Rzeczywistość, w której podejmujemy owe działania, zmienia się wraz z upływem czasu. Pokolenia naszych dziadków, pradziadków oraz ich przodków doświadczały procesu edukacji, która miała przygotować ich do życia w społeczeństwie, $\mathrm{z}$ ich czasów. Ludzie tworzący ówczesną rzeczywistość poszukiwali informacji w bibliotekach oraz trudno dostępnych gazetach, wywoływali pamiątkowe zdjęcia, by je wkleić do albumu, gromadzili się wieczorami, by opowiadać historie, chroniąc je tym samym od zapomnienia. Sytuację pokoleń żyjących przed nami należy teraz skonfrontować z obecnymi realiami, w których również nieodzowny jest proces edukacji. Nadal kierujemy się ku wyżynom rozwojowym, zdobywając najpierw podstawowe, a później coraz bardziej złożone informacje na temat świata, otaczająca nas rzeczywistość nie przypomina czasów naszych dziadków.

Istnieje subtelna różnica między kontekstem wychowywania i edukacji współczesnych dzieci a pokoleniami wychowywanymi kilka dekad wstecz. O ile dla poprzednich głównym i wyłącznym medium audiowizualnym, z którego czer-

\footnotetext{
${ }^{1}$ Z. Kwieciński, Edukacja jako wartość odzyskiwana wspólnie, „Edukacja”, nr 1/1991, s. 89.
} 
pały one treści medialne, była telewizja [...] pełniąca z zasady funkcje edukacyjno-wychowawcze, o tyle dzisiejsze dzieci inspiracje do zabaw czerpią z gotowych przekazów multilplikowanych w rozmaitych formach i gatunkach².

Edukacja dyktuje zmiany i sama jest podyktowana przez zmiany w społeczeństwie. Stanowi proces wdrażający nas do życia społecznego, musi więc współistnieć ze wszystkimi zmianami, nie ustępując im tempa. Współcześnie wyodrębniają się nowe dziedziny edukacji, wśród których znajduje się edukacja medialna, której rola w pokoleniu mediów została scharakteryzowana w niniejszym artykule.

Proces edukacji sprzężony jest z pojęciem ludzkiego rozwoju. W psychologii rozwojowej najczęściej przytaczane są cztery czynniki determinujące rozwój każdego człowieka. Wśród nich wyróżnić możemy:

- warunki biologiczne,

- sytuacje środowiskowe,

- całościowe wychowanie,

- spontaniczną, związaną z wewnętrzną motywacją aktywność własną wychowanka ${ }^{3}$.

Poprzez zadatki biologiczne rozwoju człowieka rozumiemy jego wyposażenie genetyczne, z którym przychodzi na świat. Odmienne dla każdego z nas cechy wrodzone oraz predyspozycje wpływają znacząco na to, w jaki sposób oraz w jakim tempie się rozwijamy. Do czynników środowiskowych rozwoju wliczamy natomiast każdy rodzaj otoczenia, w którym żyjemy, wyróżniając tym samym otoczenie społeczne, materialne, stymulację zewnętrzną oraz niezamierzone wpływy zewnętrzne. Wszystkie docierające do nas bodźce stanowią istotne czynniki rozwojowe. Za to, jak przebiega rozwój człowieka, odpowiada także wychowanie. Jest to jeden z najistotniejszych czynników, gdyż opiera się na działaniu intencjonalnym. Funkcjonowanie w społeczeństwie stanowi wytyczną wychowania, gdyż człowiek czerpie schematy zachowań z otoczenia. Na równi z wymienionymi czynnikami należy ulokować spontaniczną, motywowaną wewnętrznie aktywność własną jednostki. Dzięki temu, że człowiek może się motywować do poznawania, odkrywania, przeżywania oraz - przede wszystkim - tworzenia, możliwy jest rozwój każdej z jego sfer.

Bez względu na okres życia człowiek podlega naciskom biologicznym i społecznym. W szczególności w okresie dojrzewania, gdzie organizm dojrzewa i zmienia się, a także jest to okres przygotowania do życia dorosłego i zmian w obrębie społecznym ${ }^{4}$.

${ }^{2}$ A. Sugier-Szerega, Ksztattowanie kompetencji medialnej u dzieci w wieku przedszkolnym szanse, trudności, ograniczenia, [w:] A. Ogonowska, G. Ptaszek (red.), Edukacja medialna w dobie współczesnych zmian kulturowych, społecznych i technologicznych, Oficyna Wydawnicza Impuls, Kraków 2015, s. 25.

${ }^{3}$ Por. W. Tuszyńska-Bogucka, Media - przyjaciel czy wróg dziecka? Program informacyjno-edukacyjny, Wydawnictwo eMPi2, Poznań 2006, s. 11.

${ }^{4}$ Tamże, s. 12. 
Wpływ współczesnego społeczeństwa na jednostkę wymaga od niej znajomości mediów, umiejętności ich sprawnego wykorzystywania w życiu codziennym oraz otwartości na to, co stanowi novum. Wielu dorosłych twierdzi, że młodsze pokolenie o wiele lepiej porusza się w tym nowym, nieznanym dla nich świecie; stąd też rodzi się pogląd, że edukacja medialna jest młodym już niepotrzebna. W niniejszym artykule zaakcentowano zagrożenia wynikające $\mathrm{z}$ braku realizacji edukacji medialnej oraz szanse i możliwości dzieci, które świadomie poruszają się po świecie mediów.

\section{Edukacja medialna a wychowanie do życia w świecie współczesnym}

Edukacja medialna jest stosunkowo nową dziedziną, której prekursorami były Stany Zjednoczone i Wielka Brytania w latach 30. XX wieku. Rozwój mediów spowodował zmiany w koncepcji medialnej. Film ze swoją popularnością był głównym czynnikiem mającym wpływ na zmiany edukacji dzieci i młodzieży dotyczącej odbioru mediów ${ }^{5}$.

Transformacje tej dziedziny edukacji również były warunkowane zmianami realiów, w jakich żyje człowiek. Początkowo poprzez edukację medialną rozumiano odbiór filmów, natomiast wraz z upływem czasu pojęcie to poszerzano o recepcję pozostałych mediów, ich tworzenie oraz bezpośrednie i pośrednie wpływy, jakie wywierają na funkcjonowanie człowieka. Edukacja medialna była błędnie identyfikowana $\mathrm{z}$ pojęciem kompetencji medialnych.

David Buckingham podkreślał różnicę pomiędzy edukacją medialną a kompetencjami medialnymi. Edukacja medialna związana jest $\mathrm{z}$ procesem uczenia siebie i innych o mediach. Kompetencje medialne są zaś skutkiem procesu uczenia o mediach, czyli sumą wiedzy i zdobytych umiejętności uczącego się

Kontrast pomiędzy pojęciem procesu edukacji medialnej oraz nabywania kompetencji medialnych został zaakcentowany na poniższym schemacie.
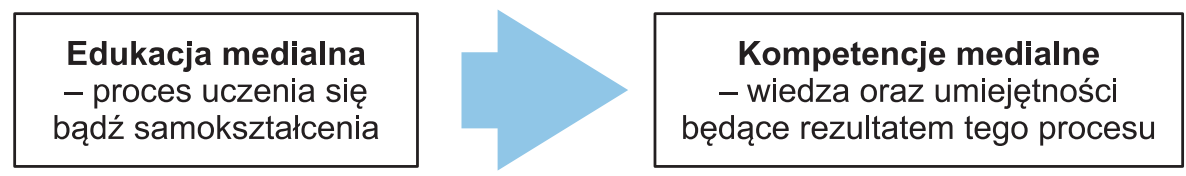

Schemat 1. Różnice między edukacją medialną a kompetencjami medialnymi

Źródło: opracowanie własne na podstawie A. Ogonowska, G. Ptaszek (red.), Edukacja medialna w dobie współczesnych zmian kulturowych, Oficyna Wydawnicza Impuls, Kraków 2015.

${ }^{5}$ A. Ogonowska, G. Ptaszek, (Re)edukacja medialna. Nowe spojrzenie na edukację medialna, [w:] A. Ogonowska, G. Ptaszek (red.), dz. cyt., s. 10.

${ }^{6}$ Tamże, s. 11. 
Schemat 1 jednoznacznie wskazuje na to, iż uzyskanie kompetencji medialnych jest rezultatem realizowania koniecznego we współczesnym świecie procesu edukacji medialnej.

Upływ czasu oraz rozwój technologii wykazały, że definicja zaprezentowana na schemacie jest jednak niewystarczająca. Współcześnie edukację medialną należy rozumieć znacznie szerzej, jako:

[...] interdyscyplinarny obszar wiedzy teoretycznej i praktycznej związanej nie tylko z kształceniem czy doskonaleniem kompetencji medialnych (informacyjnych, cyfrowych), ale również z analizą ich uwarunkowań (społeczno-kulturowych, politycznych, ekonomicznych, prawnych itp.) oraz projektowaniem na wszystkich etapach życia człowieka [...] działań służących rozwijaniu kompetencji ukierunkowanych na zaspokajanie różnych potrzeb jednostki.

Tak rozumiana edukacja medialna - o ile jest realizowana w rzetelny, dbały sposób - pozwala na kształtowanie bogatych kompetencji medialnych, których posiadania wymaga od nas otaczająca rzeczywistość. Zgodnie z opinią A. Sugier-Szeregi, budowanie kompetencji medialnych opiera się na podejmowaniu wymienionych niżej działań:

- poszerzanie ogólnej wiedzy o mediach, o ich roli we współczesnym społeczeństwie oraz wagi dla kształtowania osobowości;

- uświadamianie istnienia różnorodności nadawców, mediów, technologii medialnych oraz związanej z tym zjawiskiem konieczności dokonywania wyborów mediów, przekazów medialnych, czasu korzystania z mediów;

- poznawanie i kształtowanie umiejętności rozumienia języka mediów, a więc obrazów, muzyki, słów, kolorów, ruchu, odczytywania używanej symboliki tak, aby można było określić, jakie treści (wartości, idee, normy, zachowania, ideologie) kryją się za przekazami medialnymi;

- uświadamianie podstawowej reguły mówiącej o autorze lub autorach danego przekazu, nadawca ma bowiem jak każdy człowiek określoną świadomość, światopogląd, przekonania, może być powiązany z szeregiem zależności [...], a z pomocą mediów może swe przekonania nie tylko upowszechniać, ale i manipulować odbiorcą, także tylko dla zabawy;

- poznawanie prawa medialnego i przepisów szczegółowych na temat funkcjonowania mediów w nowoczesnym społeczeństwie;

- kształtowanie krytycyzmu wobec przekazów medialnych i odwagi posiadania własnego zdania ${ }^{8}$.

Przytoczona opinia na temat różnorodności działań podejmowanych dla budowania kompetencji medialnych nasuwa refleksję, iż edukacja medialna powinna

\footnotetext{
7 Tamże, s. 11-12.

8 Zob. A. Sugier-Szerega, dz. cyt., s. 29.
} 
stanowić odrębny przedmiot szkolny, a nie, jak obecnie zakładają autorzy Podstawy programowej ${ }^{9}$, być realizowana jedynie przy okazji zajęć z innych przedmiotów.

Uczniowie szkół podstawowych oraz szkół wyższego szczebla powinni być uświadamiani na temat tego, jaką rolę odgrywają media we współczesnym społeczeństwie oraz jaki wpływ mogą wywierać na korzystające z nich jednostki. „Pokolenie kciuka” uważa za oczywiste wpisanie niezrozumiałej frazy do przeglądarki internetowej, nie zauważa jednak potrzeby weryfikacji źródeł, ich autorów, intencji oraz znajomości danego zagadnienia. Młodzi ludzie najczęściej rozumieją język mediów, nie potrafią jednak oddzielić go od języka, którym powinni posługiwać się w świecie realnym, budując relacje z ludźmi znajdującymi się w ich otoczeniu. Dziecko lub nastolatek charakteryzuje się podatnością na wpływy zewnętrzne zwłaszcza dzięki temu, że rzeczywistość wirtualna przyjmuje niezmiernie interesujące oblicza. Proces edukacji medialnej ma za zadanie kształtować u dziecka umiejętność analizowania sytuacji występujących w mediach oraz weryfikowania tych, których intencją jest skrzywdzić ich młodego użytkownika. Wdrażane w ramach edukacji medialnej krytycyzm oraz znajomość przepisów obowiązujących w świecie mediów stają się wyznacznikami bezpieczeństwa medialnego pokolenia, które najczęściej korzysta z nich dla zabawy i zna tylko ich ludyczną funkcję.

Edukowanie medialne warto rozpocząć od rozgraniczenia pojęć, które często przytacza się jako tożsame. Zarówno w publikacjach naukowych, jak i w języku potocznym zamiennie używa się określeń: mass media, środki masowego przekazu, środki masowej komunikacji, środki społecznego oddziaływania. „Odnosi się je głównie do prasy, radia, filmu i telewizji oraz - znacznie rzadziej - także do książki, plakatu"10. Należy jednak zwrócić uwagę na to, iż określenia te różnią się między sobą zakresami znaczeniowymi, a ich zamienne stosowanie jest błędem.

I tak mass media oznaczają po prostu narzędzie informacji, środki masowej informacji akcentują masowy charakter przekazywanej informacji, środki masowej komunikacji sugerują masowe porozumiewanie się, a zatem zakładają częściowe sprzężenie zwrotne między nadawcą a odbiorcą, a określenie masowe środki oddziaływania społecznego sugerują również jednostronne wywieranie wpływu na odbiorcę. Hipermedia lub multimedia to środki techniczne, których podstawą jest komputer $\mathrm{w}$ sieci $\mathrm{z}$ oprogramowaniem połączony $\mathrm{z}$ innymi mediami $^{11}$.

${ }^{9}$ Rozporządzenie Ministra Edukacji Narodowej z dnia 14 lutego 2017 r. w sprawie podstawy programowej wychowania przedszkolnego oraz podstawy programowej kształcenia ogólnego dla szkoły podstawowej, w tym dla uczniów z niepełnosprawnością intelektualną w stopniu umiarkowanym lub znacznym, kształcenia ogólnego dla branżowej szkoły I stopnia, kształcenia ogólnego dla szkoły specjalnej przysposabiającej do pracy oraz kształcenia ogólnego dla szkoły policealnej, http://dziennikustaw.gov.pl/du/2017/356 (dostęp: 18.09.2018).

${ }^{10}$ J. Gajda i in., Edukacja medialna, Wydawnictwo Adam Marszałek, Toruń 2004, s. 26.

11 Tamże. 
Mass media, środki masowej informacji, środki masowej komunikacji oraz masowe środki oddziaływania społecznego pełnią w życiu współczesnego człowieka wiele funkcji. „Pokolenie kciuka” traktuje media głównie jako źródło zabawy oraz komunikacji z innymi, tymczasem czynników, poprzez które media tworzą kulturę, jest o wiele więcej. Autorzy publikacji zatytułowanej Edukacja medialna wskazują na pięć podstawowych funkcji kulturotwórczych mediów:

a) funkcję upowszechniania różnorodnych treści z funkcjami towarzyszącymi: informacyjną, edukacyjną, estetyczną, eksplikacyjną oraz kompensacyjną;

b) funkcję ludyczną, której towarzyszą funkcje: rozrywkowa, relaksowa oraz estetyczna;

c) funkcję stymulującą, z którą wiążą się estetyczne i wychowawcze funkcje towarzyszące;

d) funkcję wzorcotwórczą z funkcjami towarzyszącymi: wychowawczą oraz edukacyjną;

e) funkcję interpersonalną, której towarzyszą funkcje: wychowawcza oraz informacyjna ${ }^{12}$.

Zestawienie owych funkcji, ich różnorodność oraz bogactwo udowadniają, że media nie są złem. Mogą być źródłem informacji, zbiorowiskiem niezliczonych materiałów edukacyjnych, sprzyjają rozrywce, stanowią różnorodne kanały komunikacyjne, dostarczają ich użytkownikom bodźców stymulujących, umożliwiają obserwację wzorców i często wspomagają realizację procesu wychowania. Składają się na dziedzictwo, w którym odnaleźć możemy wiele przydatnych, wzbogacających nas materiałów. Edukacja medialna za cel stawia sobie uczenie nawet najmłodszych użytkowników mediów dobierania odpowiednich treści oraz współtworzenia mediów zgodnie z zasadami etyki, kultury oraz bezpieczeństwa. Jak podkreśla W. Tuszyńska-Bogucka, u „dziecka należy kształtować umiejętność korzystania z komputera i Internetu w sposób zorganizowany"13, zakładając, iż użytkowanie mediów będzie miało charakter okazjonalny, a dopuszczalne przedziały czasowe oraz zasady korzystania będą określone w zrozumiały dla dziecka sposób. Wartości, jakie przekazuje edukacja medialna zarówno dzieciom i młodzieży, jak i dorosłym, stanowią podstawy do rozsądnego, krytycznego korzystania z wiedzy, która jest nam podawana przez twórców mediów.

\section{„Pokolenie kciuka” - uzasadnienie wyboru określenia}

Specjaliści zajmujący się edukacją medialną posługują się nowym, niezwykle obrazowym określeniem, mówiąc o osobach, które większość czasu spędzają na użytko-

\footnotetext{
12 Tamże, s. 58-59.

13 W. Tuszyńska-Bogucka, dz. cyt., s. 62.
} 
waniu mediów. „Nagle sieć, którą rozwinięto dzięki eksperymentom wojskowym”" stała się narzędziem, którym z łatwością posługują się nawet najmłodsi.

„Pokolenie kciuka” to termin, który niemalże natychmiastowo przypomina nam, jaki ruch wykonujemy, chcąc sprawdzić pogodę, zrobić zdjęcie czy skontaktować się z kimś. Po chwili w wyobraźni przywołujemy obraz zatłoczonego autobusu, korytarza szkolnego podczas przerwy albo kolejki w supermarkecie. Ludzie obecni w każdym z tych miejsc również wykonują nieustanną gimnastykę kciuka, użytkując media w rozmaitych celach. Ludzie dorośli wyrobili sobie nawyk korzystania z mediów najczęściej z uwagi na charakter ich pracy bądź chęć chwilowej rozrywki, młodzież natomiast znalazła w mediach remedium na większość sytuacji - nudę, niewiedzę, zawstydzenie, chęć zdobycia uznania. Młode pokolenie ze względu na swoje medialne zainteresowania i specyficzny sposób korzystania z mediów nazywane bywa: „Internet generation, Google generation (ur. po 1993), pokolenie kopiuj-wklej, pokolenie kciuka bądź sieciaki”'15.

Przyjęte przez dzieci i młodzież nawyki częstego przebywania w świecie wirtualnym odgradzają je od świata realnego. Wydawać by się mogło, że dzięki mediom człowiek odnajduje się w takiej rzeczywistości, w jakiej pragnie. Może być złodziejem samochodów, zdobywcą diamentów bądź niezwykle towarzyską osobą, której medialnymi poczynaniami interesują się setki innych. B. Reeves zwraca naszą uwagę na istotny fakt.

Kiedy ludzie oddziałują na siebie nawzajem, przestrzeń pomiędzy nimi nabiera znaczenia. Przestrzenne usytuowanie decyduje o tym, co ludzie mówią, jak to mówią, a nawet czy w ogóle trzeba cokolwiek mówić. Czas trwania interakcji oraz jej emocjonalna intensywność mogą być zdeterminowane przez przestrzeń pomiędzy dwojgiem ludzi ${ }^{16}$.

Brak umiejętności tworzenia przestrzeni społecznej wyzwala zaniechanie budowania relacji. Dzięki temu, że wszystko można załatwić kilkoma ruchami kciuka, młodzi ludzie wycofują się z rzeczywistości, wkraczając coraz mocniej w świat medialny. Najczęściej nie zastanawiają się nad tym, czy podejmowane przez nich działania w mediach są im pomocne, czy szkodliwe; rzetelne i sprawdzone, czy podlegające wątpliwościom; liczy się dla nich jedynie szybki, sprawny dostęp do mediów oraz różnorodność otrzymywanych ich drogą bodźców.

\section{Obowiązek edukacji medialnej dzieci od najmłodszych lat}

Podsumowanie rozważań na temat tego, czy edukacja medialna jest potrzebna $\mathrm{w}$ procesie nauczania-uczenia się dzieci i młodzieży, rozpoczęto od przytoczenia

${ }^{14}$ A. Pisarek, T. Kiełkowski, Re: wizje. Program rozwoju świadomości kultury audiowizualnej w czasach nowych mediów, Muzeum Górnośląskie, Bytom 2011, s. 37.

${ }^{15} \mathrm{~J}$. Morbitzer, O istocie medialności młodego pokolenia, http://repozytorium.amu.edu.pl:8080/ bitstream/10593/10280/1/131-154.pdf (dostęp: 28.09.2018).

16 B. Reeves, Media i ludzie, Państwowy Instytut Wydawniczy, Warszawa 2000, s. 53. 
niezwykle trafnej opinii na temat dziecka w świecie mass mediów. W. Tuszyńska-Bogucka twierdzi, że:

[...] dzisiejszy świat jest zapewne w oczach dziecka jak las: pełen szumów, dziwnych blasków, barwnych plam... Odzywają się w nim różne głosy, nie zawsze wiadomo, kto jest kim... Media są podobnie magicznym światem - wykreowanym przez innych, tajemniczym i fascynującym ${ }^{17}$.

Fascynacja mediami wynika z ich ogólnodostępności, interaktywności oraz faktu, że nie mogą się znudzić dzięki bogactwu zawartych w nich treści. Zważając na to, iż współcześnie media są dostępne niemalże dla każdego, konieczne jest edukowanie dzieci i młodzieży w zakresie korzystania z nich.

Wielu pedagogów, psychologów i socjologów podkreśla [...] zasadniczą zmianę dotyczącą jakości współczesnego dzieciństwa. Staje się ono medialne, skomercjalizowane, ujęte $\mathrm{w}$ ramy bycia konsumentem niemal od pierwszych dni życia. Dzieciństwo wypełnione treściami audiowizualnymi, które tworzą konkurencyjne dla rodziny i instytucji wychowawczo-opiekuńczych środowisko edukacyjno-wychowawcze, stymuluje i warunkuje rozwój psychofizyczny dzieci, a zarazem od początku uczy, jak być konsumentem, wręcz uzależnia i czyni ten wymiar uczestnictwa w życiu społecznym niemal podstawowym dla kształtowania ich świadomości i tożsamości ${ }^{18}$.

Uczymy dzieci jazdy na rowerze, by unikały wypadków, w których może im stać się krzywda, zapominamy jednak o wpajaniu im umiejętności bezpiecznego korzystania z mediów. Podczas lekcji języka polskiego dążymy do tego, by dziecko odgadło, z jakimi intencjami autor tworzył swe dzieło, nie koncentrujemy się jednak na podkreślaniu tego, że nie każdy w świecie mediów dysponuje rzetelnymi informacjami i ma jedynie dobre zamiary. Oswajamy dzieci z pojęciami naukowymi, jednakże określenia wprost ze świata mediów często są im obce. Rozważania te mają na celu uświadomienie, iż świat mediów dla dzieci i nastolatków stanowi otoczenie tak samo istotne i naturalne, jak chodnik, po którym jeździ na swoim rowerze.

Dzieci już od wieku niemowlęcego oglądają treści na tabletach, telefonach komórkowych czy innych zminiaturyzowanych urządzeniach. Skutkuje to tym, że nie muszą się uczyć ich obsługi, gdyż jest ona wpisana w ich życie codzienne. Atrakcyjność takich gadżetów powoduje, że umiejętność obsługi nie stanowi wyzwania dla najmłodszych ${ }^{19}$.

Właściwie realizowana edukacja medialna to wyzwanie, wymóg współczesności spowodowany ekspansją medialną i rozpowszechnianiem wszechobecnej informacji. Jest to też działalność edukacyjna, która skupiona jest na wejściu w przestrzeń użyt-

\footnotetext{
17 W. Tuszyńska-Bogucka, dz. cyt., s. 23.

18 A. Sugier-Szerega, dz. cyt., s. 25.

19 Tamże.
} 
kowników świata medialnego ${ }^{20}$. Zakłada ona nabywanie kompetencji, które wymieniono poniżej:

a) umiejętność oceny i doboru wartościowych komunikatów oraz weryfikacji ich pochodzenia i autentyczności;

b) umiejętność tworzenia materiałów multi-i hipermedialnych przy użyciu popularnych w danej chwili metod i narzędzi;

c) zdolność do współpracy w grupie przy użyciu nowoczesnych technologii komunikowania;

d) umiejętność krytycznego odbioru komunikatów medialnych, w oparciu o tworzenie medialnych treści ${ }^{21}$.

Obowiązek edukacji medialnej spoczywa obecnie na nauczycielach niemalże wszystkich przedmiotów, którzy powinni włączać w realizację programu wykorzystywanie mediów w procesie edukacji. Powszechność dostępu do mediów wyzwala jednak konieczność realizowania edukacji medialnej osobno, a nie jako dodatkowego obowiązku w ramach dotychczasowych przedmiotów. Ogrom treści, jakie dzieci powinny nabyć w ramach edukacji medialnej, winien być zebrany w formie podręczników oraz zestawów ćwiczeń. „Pokolenie kciuka” niezwykle sprawnie porusza się w świecie mediów, nie zna jednak podstawowych zasad korzystania z nich. Sytuację tę można porównać do dziecka, które nie zostało nauczone zasad ruchu drogowego, a następnie zostało samo wypuszczone na ruchliwą jezdnię z mnóstwem atrakcji dookoła.

\section{Zakończenie}

Człowiek jest uczestnikiem społeczeństwa informacyjnego, a towarzyszące mu w życiu codziennym media są dla niego interesującym źródłem rozrywki, wiedzy i informacji. Kształtują światopogląd jednostki, jej spojrzenie na rzeczywistość, a także postawy, co powoduje, że zaczęły pełnić rolę nieformalnej instytucji wychowawczej ${ }^{22}$.

Najbardziej niepokojący jest fakt, iż do mediatyzowania dzieciństwa przyczyniają się często sami rodzice, podsuwając dzieciom sprzęty multimedialne, w celu zapewnienia im rozrywki. Nie możemy jednakże pozwolić na to, by media bez wyraźnie określonych zasad i granic użytkowania przejmowały kontrolę nad sposobem myślenia, komunikowania się oraz reagowania na sytuacje społeczne dzieci oraz nastolatków. Należy uświadamiać rodziców, nauczycieli, dzieci oraz młodzież, iż „edukacja medialna to zadanie ogólnospołeczne, ponieważ wszyscy obywatele są użytkownika-

${ }^{20}$ D. Muszyński, G. Stunża, Co to jest edukacja medialna?, http://www.nina.gov.pl/baza-wiedzy/ co-to-jest-edukacja-medialna (dostęp: 1.10.2018).

${ }^{21}$ Tamże.

${ }_{22}$ B. Krzesińska-Żach, Edukacja medialna dziecka w rodzinie - wybrane aspekty, [w:] J. Izdebska, T. Sosnowski (red.), Dziecko i media elektroniczne - nowy wymiar dzieciństwa, Trans Humana, Białystok 2005, s. 55. 
mi i beneficjentami różnych technologii, które wykorzystują we wszystkich kluczowych sferach własnego życia”23. Realizacja tego zadania powinna stać się obowiązkowym, odrębnym obok technologii informacyjnej przedmiotem szkolnym, a ponadto winna stać się przedmiotem warsztatowego kształcenia rodziców. Od ich postaw zależy, czy kilkulatek sięgnie po interaktywny sprzęt elektroniczny, utrwalając nawyk przesuwania kciukiem treści, które nie zawsze są dla niego odpowiednie.

\section{Bibliografia}

Gajda J. i in., Edukacja medialna, Wydawnictwo Adam Marszałek, Toruń 2004.

Izdebska J., Sosnowski T. (red.), Dziecko i media elektroniczne - nowy wymiar dzieciństwa, Trans Humana, Białystok 2005.

Krzesińska-Żach B., Edukacja medialna dziecka $w$ rodzinie - wybrane aspekty, [w:] J. Izdebska, T. Sosnowski (red.), Dziecko i media elektroniczne - nowy wymiar dzieciństwa, Trans Humana, Białystok 2005.

Kwieciński Z., Edukacja jako wartość odzyskiwana wspólnie, „Edukacja”, nr 1/1991.

Morbitzer J., O istocie medialności młodego pokolenia, http://repozytorium.amu.edu. pl:8080/bitstream/10593/10280/1/131-154.pdf (dostęp: 28.09.2018).

Muszyński D., Stunża G., Co to jest edukacja medialna?, http://www.nina.gov.pl/baza -wiedzy/co-to-jest-edukacja-medialna (dostęp: 1.10.2018).

Ogonowska A., Ptaszek G., (Re)edukacja medialna. Nowe spojrzenie na edukację medialna, [w:] A. Ogonowska, G. Ptaszek (red.), Edukacja medialna $w$ dobie współczesnych zmian kulturowych, społecznych i technologicznych, Oficyna Wydawnicza Impuls, Kraków 2015.

Ogonowska A., Ptaszek G. (red.), Edukacja medialna $w$ dobie współczesnych zmian kulturowych, społecznych i technologicznych, Oficyna Wydawnicza Impuls, Kraków 2015.

Pisarek A., Kiełkowski T., Re: wizje. Program rozwoju świadomości kultury audiowizualnej w czasach nowych mediów, Muzeum Górnośląskie, Bytom 2011.

Reeves B., Media i ludzie, Państwowy Instytut Wydawniczy, Warszawa 2000.

Rozporządzenie Ministra Edukacji Narodowej z dnia 14 lutego 2017 r. w sprawie podstawy programowej wychowania przedszkolnego oraz podstawy programowej kształcenia ogólnego dla szkoły podstawowej, w tym dla uczniów z niepełnosprawnością intelektualną w stopniu umiarkowanym lub znacznym, kształcenia ogólnego dla branżowej szkoły I stopnia, kształcenia ogólnego dla szkoły specjalnej przysposabiającej do pracy oraz kształcenia ogólne-

\footnotetext{
${ }^{23}$ A. Ogonowska, G. Ptaszek, dz. cyt., s. 17.
} 
go dla szkoły policealnej, http://dziennikustaw.gov.pl/du/2017/356 (dostęp: 18.09.2018).

Sugier-Szerega A., Ksztaltowanie kompetencji medialnej u dzieci w wieku przedszkolnym - szanse, trudności, ograniczenia, [w:] A. Ogonowska, G. Ptaszek (red.), Edukacja medialna $w$ dobie wspótczesnych zmian kulturowych, społecznych i technologicznych, Oficyna Wydawnicza Impuls, Kraków 2015.

Tuszyńska-Bogucka W., Media - przyjaciel czy wróg dziecka? Program informacyjno-edukacyjny, Wydawnictwo eMPi2, Poznań 2006.

\section{Media education of the "thumb generation" - triviality or duty?}

Abstract: Adults often think that the use of media, especially of the Internet and of increasingly advanced multimedia devices, is something new for them, which they are not always able to deal with effectively. People who are most often asked about the effective use of media resources are their children. They are called the thumb generation because they spend the most time on media use. There is a view among society that children and adolescents are specialists in using networks or devices with increasingly advanced capabilities. Bearing this opinion in mind, a question arises about the legitimacy of implementing multimedia education among people who often move more efficiently in the virtual world than on the pavement. This article describes the role of education in a person's life, discusses the effects of media education, and then discusses the dangers posed by ignorant use of media.

Keywords: media education, thumb generation, media competence, media

About the author: Renata Matusiak - Doctor of social sciences in the discipline of pedagogy. Master's degree in sociology at the John Paul II Catholic University in Lublin. She studied social prevention and addiction therapy, criminology, pedagogical preparation. She is an organiser and participant of numerous international and national academic conferences, editor of collected works, and the author of academic articles. Research interests: media education, new media, cybercrime, network security. 


\title{
Agnieszka Krawczyk* (iD https://orcid.org/0000-0003-0211-3132 \\ Uniwersytet Łódzki \\ The meaning of Jewish culture of origin for Jewish women from the third generation ${ }^{1}$
}

DOI: 10.25312/2083-2923.15/2019_09ak

\begin{abstract}
This article draws on four free-form interviews with elements of narration, which I conducted with representatives of the "third generation" of people of Jewish origin living in Łódź. In my text, I refer to the knowledge (and lack of knowledge) of the surveyed women as to their roots. I also distinguish two family models they have created. I place Jewish culture and religion in the context of the women's everyday experiences.
\end{abstract}

Keywords: women, Jewish origin, family, third generation

\section{Introduction ${ }^{2}$}

In this article, I present some results of the research I conducted among people of Jewish origin. I focus on the meaning of this origin for young women - from the third generation - and the way it manifests itself in their family lives. The context for the present deliberations is the breakage or reversion of intergenerational transmission in the Jewish community.

The article interprets four free-form interviews with elements of narration (out of sixteen interviews I organised while preparing my doctoral thesis). An advantage of this approach is that the researcher does not impose any particular form of narration

Agnieszka Krawczyk - MA in Slavic Philology and Pedagogy; Assistant Professor at the Department of Educational Studies at the Faculty of Educational Sciences, University of Lodz. Research interests are: multicultural pedagogy, culture, Jewish culture, narratology, methodology, qualitative research, literature, children's and juvenile literature.

${ }^{1}$ Part of the research and translation was done as part of the grant: young scientists research project No. B1611800001308.02 entitled: "Multiculturalism experienced by Łódź inhabitants of Jewish origin".

${ }^{2}$ I would like to sincerely thank Prof. Danuta Urbaniak-Zając for consultations and advice. 
on the interviewees. Narrations presented by the respondents were formulated in response to my questions. The questions, however, were sufficiently open to be regarded as discussion topics rather than typical questions. As a result, my respondents could speak freely, or even digress. I conducted my research from March 2015 to December 2016. The selection criteria for the research sample were: Jewish background, connection with Łódź (I was interested in the current inhabitants of the city, as well as people who used to live there in the past) and age from approximately 25 years, without any upper limits. Initially, I planned to involve the representatives of three generations: the oldest ('grandparents'), the middle ('parents') and the youngest ('grandchildren/children'). Despite quite general age criteria, the people who contacted me were mainly in the age group from 30 to 40 years, which reflects the absence of the representatives of the oldest and the middle generation in the Jewish community of Łódź. Out of 16 research participants, 12 people represent the youngest generation, 2 - middle, and 2 the oldest. Using the snowball method during selection, I asked particular research participants to provide the contact details of their parents, grandparents or other representatives of older generations. However, I managed to obtain those details in very few cases. The research participants justified this situation with their parents not being interested in their origin, afraid to talk about it or having no knowledge of Jewish culture.

At the time of conducting the interviews, the research participants were aged 31 to 38 (Judyta - 31, Dominika - 32, Ola and Katarzyna - 38; for the sake of anonymity, the research participants were given fictitious names). All of them are married women with higher education. Only one of them is married to a Jew, all the others are in mixed marriages with Catholics.

I start the next part of this article by explaining the notion of the 'third generation' followed by information on the respondents' knowledge (or lack thereof) about their origins. Then, I distinguish two main types of families started by the women, in order to place Jewish culture and religion in their daily life.

\section{Women's knowledge (or lack thereof) about their Jewish origins}

The 'third generation's includes people currently aged approximately 30 to above 40. These are the grandchildren of people who lived during the Second World War. It is more of an informal term, as the people from the said age group include also children of the war generation representatives. Another notion to describe the aforementioned people is '(adult) grandchildren of the Holocaust'4, while people from the

${ }^{3}$ This notion appears, among others, [in:] J. Cukras-Stelągowska, Małżeństwa mieszane w społeczności żydowskiej - abberacja czy norma społeczna?, „Wychowanie w Rodzinie”, No. XIV (2/2016).

${ }^{4}$ This notion appears, among others, [in:] A. Mazor, I. Tal, Intergenerational transmission: the individuation process and the capacity for intimacy of adult children of Holocaust survivors, "Contemporary Family Therapy", March 1996, Vol. 18, Issue 1. 
second generation are referred to as '(adult) children of the Holocaust.' Polish representatives of the third generation are characterised by a willingness to go back to their roots, meaning an interest in Jewish culture, including, in some cases, Judaism, which stands in contrast to their parents, who had a tendency to deny, hide or attribute little significance to the culture of their origin. The second generation is virtually absent in Polish Jewish organisations. Parents, brought up by grandparents in an atmosphere of fear, being the result of the Second World War, tried to avoid any contact with broadly understood Judaism and Jewish culture. Protected by their parents, they failed to pass the traditions (which were often unknown to them) on to their children. Here, the intergenerational transmission was broken, as a result of which young people seek contact with their origins on their own, learning about their culture and, in some cases, introducing their parents to it.

Judyta comes from a family of artists, which has been in touch with assimilated Jews for generations. Her grandmother brought up her mother keeping her aware of their Jewish background, but with no connection with religion, which is not typical of the Jewish culture, in which the secular and the spiritual sphere tend to overlap. Also, the multi-generational awareness of roots is rare among people of Jewish origin living in Poland, but Judyta has always known about it. She did not experience any breakthrough in her life, related to discovering a secret. In Judyta's family, Jewish culture was nurtured not only by her grandmother, but by her mother as well. However, in this case, culture should be understood in a narrow sense, as it covered mainly artistic activity. When asked about traditions, Judyta answered: no, not at home, we didn't have that tradition at home (230/7/W5). Her family did not celebrate Jewish holidays. But My mum used to take me to the synagogue, and I grew up with the Jewish culture festival [...] Mum used to go there with me, when I was a little girl, I took my friends there too $(230-233 / 7-8 / \mathrm{W} 5)^{5}$. It should be emphasised that her mother used to take her both to a synagogue and to a church, which, however, had only cultural, and not religious, meaning for both of them. The mother taught her daughter artistic sensitivity, teaching her about architecture and art. During those visits to places of worship and during trips abroad, they looked at paintings, icons, and became acquainted with the culture typical of a given region.

The other two respondents, Dominika and $\mathrm{Ola}^{6}$, were also brought up aware of their origins, although, in their opinion, it was not particularly important for members of their families. Nevertheless, they managed to become acquainted with Jewish holidays, religion, etc. Dominika describes the awareness of her origins as follows:

${ }^{5}$ At that time Judyta lived in Krakow, and the festival she mentions is the Jewish Culture Festival, www.jewishfestival.pl/en.

${ }^{6}$ About Dominika and Ola see: e.g. A. Krawczyk, Wielokulturowość oddalona od pogranicza. Na przykładzie doświadczeń biograficznych członków łódzkich stowarzyszeń żydowskich, [in:] A. Rzepkowska (ed.), Odmienność w kulturze, Wydawnictwo Naukowe Uniwersytetu Mikołaja Kopernika, Toruń 2017. 
I've always known it, or at least most of the time (36/2/W2), and it was probably when I was a child, but I can't remember it that well. No, it was no big secret (44-45/36/W2). In Dominika's home, Jewish holidays were celebrated sometimes, albeit not in a regular manner; also, the family members did not emphasise the fact that a particular holiday was celebrated at a given moment. For example, during Hanukah and Passover, family reunions were organised, and potato pancakes were served during Hanukah. Moreover, festive family dinners took place not on Sundays (like in the homes of most of Dominika's friends), but on Saturdays.

Dominika's claim as to irregularity in celebrating holidays rooted in Jewish tradition should be treated carefully, as this claim may be the result of selective memory. Adult people do not have to necessarily remember all the events from their childhood, and tend to remember those accompanied by emotional experience and meaningful associations. This could be the case with Dominika - maybe family holidays were celebrated on every occasion, and she remembered only some of them? Moreover, the families of both respondents did not celebrate Catholic holidays - this is unusual for families of Polish Jews, who often tend to treat such holidays as a national tradition, and celebrate them according to the Catholic calendar. A Christmas tree was never present at Dominika's house, although as a child she used to ask her mother to buy one. Dominika's mother refused, saying that a plastic tree would not be aesthetic, and that the needles falling off a real tree would make a mess. It could be presumed that this was just an excuse for the sake of a child, who would be more able to understand such arguments, rather than the details of her family's cultural diversity. Those details were also not very well known to Dominika's mother, who learned about the particular aspects of Jewish culture later on, thanks to her daughter. It is an example of a broken (parents not participating in culture) or reversed (children teaching their parents their culture of origin) intergenerational transmission. This would mean that Dominika's grandfather did not care about systematisation of his daughter's knowledge. The respondent remembers, however, that her grandfather used to take her to the synagogue. He died when Dominika was eight years old.

As previously mentioned, the respondent knew the customs accompanying particular holidays, however, family members did not explicitly state the fact of celebrating these occasions. This could be caused by the fact that Judaism is not a dominant religion in Poland, and an additional, external reinforcement was missing here. Children from Catholic families learn about celebrating particular holidays not only from their relatives, but also from teachers, friends, the media or by observing decorations in shops. This is also confirmed by what Dominika said. In her opinion, children from convert families have more extensive knowledge about Judaism and celebration of various holidays, since for them it was not an obvious fact - at some point, somebody in their families decided to convert and had to learn all that was related to it.

On the other hand, Ola grew up in an atheist family, where the members of preceding generations were not interested in celebrating any holidays. The main source 
of contact with the Jewish tradition for Ola was the information her grandmother spoke of openly, related to the latter's war experiences and traumas. Ola never perceived her cultural affiliation as a sign of her distinctness - Jewish identity was something obvious to her; she even said: I thought it was natural that grandmas in other homes might do the same (176-177/6/W3) - meaning they might sing songs in the Yiddish language to their grandchildren. Despite the knowledge of her Jewish origins, Ola still feels there were things left unsaid in her family: even now, I feel that I should talk about certain things with my father, but I fail to do so. And I know that maybe we'll never talk about it (154-156/5/W3). The respondent adds that even after her grandmother's death, her father avoided discussing certain topics. This has resulted in a certain loop. Ola says that her father might have expected her to ask him if she wanted to know something. However, she asked one time, but received no answer in return. Therefore, even in families in which the origin was not kept secret, the youngest generation had the impression that not everything was clear and that there were certain topics not to be discussed. Dominika and Katarzyna have also experienced this blockade. It consists of the presence of certain taboos in a family - topics which younger family members would like to talk about, but which are blocked by their parents and grandparents, as well as in avoiding talking about experiences hard to describe by those who went through them ${ }^{7}$.

Katarzyna was brought up in a Catholic family. She herself was a very religious and spiritual person. She learned about her Jewish origins around the age of 14, when she came back from school and told her mother a joke about Jews. Then, her mother informed her of their Jewish roots, and immediately made a secret of it, forbidding Katarzyna to tell anyone about it, even immediate relatives, such as her brother and stepfather. She refers to her origins in an impersonal manner, saying: it wasn't discussed at home (65-66/3/W4). She does not use phrases such as we didn't talk about $i t$, as if her origin was some mysterious, vague force, difficult to assign to a particular addressee. Discovering the truth about her roots was a very difficult experience for her, involving a trauma Katarzyna hasn't managed to overcome until now. As a result, she turned to therapy.

Failure to handle traumatic experiences of the Holocaust, and transferring them to younger generations, is a global phenomenon, present not only among Polish Jews. It entails passing two types of experiences to the next generations. The first one consists in the eldest generations keeping their private, dark sphere. This results in difficulties in establishing closer relations with the relative who experienced the Holocaust. On the other hand, it is possible to notice that fears are passed on to younger family members. They are not sure what they are afraid of, but nevertheless, they fear

${ }^{7}$ H. Greenspan, The Unsaid, the Incommunicable, the Unbearable and the Irretrievable, "Oral History Review", No. 41/2014, pp. 229-243. 
the unspoken ${ }^{8}$. Katarzyna had a similar experience, growing up with the implicit fear which her grandfather passed on to her mother, who, in turn, transferred it to her daughter. The fear exacerbated after the birth of Katarzyna's child, and it was then that the respondent decided to take up therapy, to finally stop this transmission of intergenerational fears. Another phenomenon independent from the country of residence is the presence of fear and inadequate response to current situations, which has a negative effect on families of younger generations of people with Jewish roots ${ }^{9}$. For Katarzyna, it was her failure to take notice of her overly emotional reactions or undertaking unnecessary actions. An example here might be a moment when Katarzyna's child became sick - then, the respondent wanted to travel a long way back to her hometown, since staying with her relatives, during a situation which she felt was threatening, was supposed to give her a sense of security. Such behaviours caused arguments in her marriage, and it was Katarzyna's husband who made her aware of how irrational they were.

Confusion related to a family secret is deepened by the fact that Katarzyna has been unable to fully determine her sense of inclusivity. Katarzyna herself says she feels like a 'half-breed.' The reason for using such a term is twofold - firstly, the respondent is not a Jew in the female line, which, according to orthodox Judaism, means she is not Jewish at all. At the same time, such a feeling may result from the family's powerlessness; when it comes to Jewish issues, there is a problem with determining the identity, resulting from uncertain cultural affiliation. The family denies their origin. Katarzyna cannot count on their support, but she has also been unable to find it in an orthodox Jewish community. Her family thinks that her focus on Jewishness has become her obsession. The Jews among whom she lives do not perceive her as 'completely' Jewish, so she has difficulties in determining her own identity. The respondent says: I'm somewhere in-between (272/9/W4). She is unable to choose one side in $100 \%$, as she does not feel she belongs to either of them - this might be the reason for her incomplete conversion. This might also give an apparent sense of security - being in a Jewish world, she has her people in the outside world, while being in a non-Jewish environment, she still has her people in the Jewish one. To confirm it, she recalls a conversation with her mother, who told her not to talk about her Jewish roots, and warned her about negative consequences such actions may have for her daughter. In response, Katarzyna said she had no fear, as she had her loved ones (husband, friends) always by her side. However, the truth is Katarzyna does not seem to be a person full of confidence - she is quite confused and does not feel secure in any environment.

The lifestyle related to her origins, the awareness of ethnic affiliation, as well as teaching her child the principles of Jewish culture, or even information about their

8 A. Mazor, I. Tal, Intergenerational transmission: the individuation process and the capacity for intimacy of adult children of Holocaust survivors, "Contemporary Family Therapy", No. 18/1996, pp. 95-113.

${ }_{9}$ Above, pp. 95-113. 
origin, is of crucial important for the future life of a young boy or girl. In fact, the respondents brought up with the sense of Jewish ethnic affiliation, treated it as a natural element of their identity, which later facilitated establishing families and having children, as they did not experience internal conflicts. The respondents obliged by their parents not to reveal their roots to outsiders and to other relatives experienced difficulties in doing so.

\section{The place of Jewish culture and religion in the everyday life of women}

The respondents established two basic family types - monocultural and multicultural, with the addition that the latter type includes two subtypes - marriage with and without children, as shown in the below specification:

\begin{tabular}{|c|c|c|}
\hline $\begin{array}{c}\text { Monocultural/monoreligious } \\
\text { families }\end{array}$ & \multicolumn{2}{|c|}{ Multicultural/bi-religious families/mixed marriages } \\
\hline Family with numerous children & Married couple with a child & Married couples with no children \\
\hline Judyta & Katarzyna & $\begin{array}{c}\text { Dominika } \\
\text { Ola }\end{array}$ \\
\hline
\end{tabular}

Judyta, brought up in an atheist community of Jewish artists, has established a religious Jewish family with her husband and children. She was not always a religious person. She became like that when, as a student and an active member of one of the Jewish organisations, she met her present husband. She summarises it as follows: And... And it turned out that there is something like Judaism, with lots of principles and rules, and suddenly I realised that these rules make me feel really good (412-414/13/ W5). Judyta, being aware of her origins, certainly knew that there is something like Judaism, and she knew that such a religion exists. Sudden realisation could rather mean her surprise to find that religion could be of interest to a non-religious person like herself. Judaism probably appeared as an outcome of the need to live with a religious man. Particular rules - regardless of the cause for interest in them - have become permanent elements of Judyta's life, and they give her genuine pleasure. Encouraged by her partner, she started exploring this religion, and then adopted its rules in her daily life. This means that currently, Judyta, her husband and children cultivate the Jewish principles on a daily basis, they say the berakah at appropriate moments, eat kosher food, adhere to every Sabbath and all the rules related to it, and they also celebrate all typically Jewish holidays. Moreover, it should be mentioned that, in the Jewish community, they serve as a rabbi and a rebbetzin, which obliges them to perform the aforementioned activities; at the same time, however, the social functions they have accepted are a consequence of the earlier turn to religious life. Their marital bond is warm, cordial and friendly (which can be concluded not only from the interview with 
Judyta, but also from a conversation with her husband). They try to comply with all the rules stipulated in the Torah and the Talmud, and also with the principles characteristic for a broadly understood Jewish community.

Katarzyna was not brought up aware of her Jewish origin, which, in her family, was perceived as a stigma and a thing to deny. However, she always felt the urge for spirituality, which she initially tried to satisfy by active participation in Catholic culture. In time, the search for her own religious path and contact with her roots, led her to Jewish culture. For a while, she was in a relationship with a Jew and considered the decision to convert. After their relationship ended, she did not fulfil her plans. Nevertheless, it would be an oversimplification to conclude that she decided not to convert only due to the break-up - Katarzyna herself is not sure of such a linkage. Her way of narration might imply that she is reluctant to institutionalise her life and formalise its particular aspects. At present, she is married to a Catholic, with whom she tries to merge the customs of both cultures and religions. Consequently, they celebrate both Catholic and Jewish holidays. Katarzyna’s husband tries to support her in cultivating her religions and in overcoming her childhood fears, passed on from generation to generation, starting from her great-grandfather and her grandfather, who experienced the horrors of war.

Dominika and Ola, similarly to Katarzyna, are married to Catholics. All three respondents decided to enter into civil marriages with their partners, however, Dominika and Ola are open to their husbands' religion. Dominika refers to it by saying: we learn about each other (334-335/11/W2). They themselves were not brought up in Catholic culture; they did not attend religion lessons at school and they did not go to church. Each of them participates in Mass only to accompany their husbands, but nevertheless, they try to engage and learn as much as they can about Catholicism. This often surprises representatives of the Catholic Church, unaccustomed to a situation in which participants of the Mass stay in the church after it, to ask the priest some questions or request clarification of complicated issues. The respondents and their husbands celebrate both Jewish and Catholic holidays. Dominika, thanks to her husband's culture, has managed to make her unfulfilled childhood dream come true every Christmas they decorate a Christmas tree:

but I really wanted to have the tree (...) Now, I live with my husband in our little apartment, and since our home is so tiny, also our tree was the size of this fern, but it was there anyway. We watered it and cared about it, but it withered in March, unfortunately (89-92/3/W2).

At the same time, celebration of holidays - both Jewish and Catholic - does not entail any attachment to religion. Dominika explains it as follows:

when we first met, and then started going out with each other (...) he [husband] participated in Seders, one or two times he came for Passover or some other meetings we had, and he really got into it, he read aloud, finding it hard to pronounce all those names, and I think that's all - neither of us is really religious (32-327/10/W2). 
The lack of religiousness may be the key to the success of mixed marriages strongly religious people would definitely be less open to their partner's culture and would not agree to partake in the customs related to it.

In the past, when someone wanted to marry a person of a different denomination, it was necessary for one of them to accept the religious beliefs of their partner. Contemporary times offer more opportunities in this respect. Judging by the experiences of the respondents, it can be said that these are not just formal opportunities - a bi-religious family is not a problem in the informal sphere. Reconciliation of traditions of two cultures in one family requires the openness of each partner to the other person's customs and the will to discover them.

Judyta claims that Judaism is not a rigorous religion, leaving a certain amount of freedom to children: if a four-year-old takes his yarmulke off, his parents don't have to chase him. The thing is that if kids are forced into anything, they will abandon it in the future (533-536/16/W5). However, children are given freedom to the extent permitted by the rules of Judaism. Rules and principles are adapted to the age and perceptive capabilities of a child. Simultaneously, parents try to minimise the feeling of loss in their children - if the children see somebody at school eating non-kosher food, which they themselves cannot eat, their parents give them something else - something attractive to them.

Judyta and her husband try to bring their children up in isolation from the dominant culture. Their daughters attend a Jewish kindergarten and, in general, have no contact with people from beyond the Jewish community. It is a kindergarten which according to the respondent - was established for them by myself (505/16/W5). It is not certain whether such an attitude of Judyta proves the need to control the education of her children, or maybe the feeling of responsibility for their education. Her son attends a democratic school, where religion classes are not held, which was the main argument when choosing the place of the boy's education. At the same time, Judyta's son does not participate in school-related activities, such as school trips for the birthday parties of his friends. When describing this situation, Judyta claims it is easier this way, but it can be presumed that it makes things easier above all for the parents, rather than the child. If their son went on a school trip, they would not have control over what their child eats; this, in turn, might provoke their son to give up the kosher diet for a moment (for example, if another trip participant offered him snacks containing pork, brought from home). Judyta's son does not go to his friend's birthday parties, because they are usually organised on Fridays or Saturdays - during Sabbath. He doesn't go to parties. Especially those birthday parties that take place on Saturdays. It's out of the question (636-637/19) - it is a stringent statement, beyond any discussion. In this area, her son does not have as much freedom of choice as, e.g., with wearing a yarmulke. It is an unbreakable rule. Her son, similarly to his sisters, has virtually no contact with people from beyond the Jewish world. He only encounters them at school, in the context of specific rules, allowing the parents to interfere significantly. 
It should be added that, for a child at the age of Judyta's son, socialisation is very important - at this age, children tend to move away from what their parents have taught them, as parents are no longer the most important people to them. Secondary socialisation starts when a child reaches the age of Judyta's youngest daughter. Thus it can be concluded that socialisation is significantly limited for all of her children. Going to a kindergarten, a child discovers new rules, views, and lifestyles, confronting them with what he/she has learnt at home. In the discussed case, the daughters attend a kindergarten established by their mother and managed according to the principles which she represents. It is true that Judyta's son attends an external school, and is able to experience such a confrontation, but it is not fostered by informal contacts with his friends, for example in the playground or in other children's homes. Therefore, it is difficult to precisely state to what extent the choices made by the boy are really his choices.

The parents also do not maintain numerous social relations with people not involved in Jewish culture. Due to their social functions, they spend most of their time with representatives of Jewish culture; they find it hard to distinguish work time from private time, as their entire life focuses on their Community, so they do not have many opportunities to meet non-Jewish people.

Katarzyna and her husband bring their daughter up in both of their cultures, but with a clear distinction of which religion 'belongs' to a particular parent. This means that the mother takes her child to the Community and introduces her to Jewish culture. Katarzyna keeps searching for new perspectives and is open to help from the outside world, so when she realised her knowledge was insufficient, she (and her husband) decided to send her daughter to a Jewish kindergarten, where she would be educated by people specially prepared for this task. However, it was not a simple decision - it raised many doubts, and also objections on the part of Katarzyna's mother. On the other hand, the respondent's husband takes their daughter to church for Mass and provides her with information about his culture. Katarzyna has doubts similar to those troubling Judyta - she does not want her daughter to attend religion classes at school, but she also does not want her child to be excluded from certain activities related to Catholic religion in state schools. At the same time, she does not mind her husband taking care of their daughter's education. It is possible to observe a certain contradiction here, as it means that, according to Katarzyna, one culture will be communicated better by specially prepared people, and the other - through education in home surroundings. At the same time, Katarzyna and her husband do not require their child to choose any religion - she has not been baptised, and the decision regarding which religion to choose or abandon is completely up to her. However, after giving birth to her child, Katarzyna started feeling a growing fear related to her Jewish origin, and began to imitate her mother's patterns of behaviour. Patterns she always criticised and wanted to avoid, but which manifested themselves in crisis situations and which she realised thanks to her husband. 
It is difficult to present the social relations of Katarzyna's daughter in any way, as the girl is still too young. The respondent, in turn, engages in relations with various people, regardless of their background and religion - these are predominantly people from the environment of artists, as Katarzyna herself is a representative of this profession.

Katarzyna and Judyta present diverse strategies of introducing their children to their ancestors' culture, which results, above all, from the differences in their knowledge and the access to this culture, and which may be rooted in the way the respondents were brought up by previous generations. Judyta herself takes on the responsibility for educating her children, trying to protect them against the impact of the external (dominant) culture or even cultures (any other than the dominant one). Katarzyna, on the other hand, entrusts her daughter's education to people she considers specialists. At the same time, she does not protect her child from an 'alien' culture, as her husband represents the culture she herself refuses to accept. In this situation, Katarzyna sees her husband as an expert in Catholic culture. Trust towards specialists in one's own culture is a characteristic situation, not only for Polish Jews. Similar attitudes are presented by people interviewed by Lena Inowlocki. Her respondents come from Belgium, the Netherlands and Germany, and represent the second generation of people with Jewish background. One of the women who grew up in Germany was, in her childhood, allowed to play only with Jewish children, and her parents forbade her to make friends with young Germans ${ }^{10}$. In the case of Judyta's children, this prohibition is not as strong as in the said case, since her son contacts children of various origin at school. Outside school, however, his parents do not provide him with conditions to keep in touch with children representing the dominant culture. The respondent in the test by Lena Inowlocki referred to her childhood as life in a ghetto, and she created for her daughter a space to live in a diversified environment; nevertheless, she sent her child to a Jewish school and to private lessons, which, in turn, is typical of the attitude shown by Katarzyna. Such an attitude of both women results from the awareness of insufficient knowledge of Jewish culture, making them willing to provide access to it for their children, through formal Jewish education. The aim of such action is to shape their children's awareness of their origins ${ }^{11}$.

\section{Conclusion}

Religion is an important reference point in shaping individual identity - each respondent strongly focused, in what they said, on religious issues, trying to identify themselves by referring to religion.

${ }^{10}$ L. Inowlocki, Doing „Being Jewish”: Constitution of „Normality” in Families of Jewish Displaced Persons in Germany, [in:] R. Breckner, D. Kalekin-Fishman, I. Miete (eds.), Biographies and the division of Europe: experience, action and change on the 'Eastern side', Leske + Budrich, Opladen 2000.

${ }^{11}$ Above. 
Based on the analysis of interviews conducted with the aforementioned respondents (but also with others, whose lives have not been discussed here), it can be stated that currently, in Poland, there is no single Jewish community which would behave in a characteristic manner. Every family functions in a particular way, resulting from the past experiences of their ancestors, and has different ways to make younger generations aware of their background and to take actions related to this awareness.

To a large (or maybe to the largest) extent, the approach of an adult to his/her origins depends on how family members engage with this origin and culture. If this origin and culture is valued, children may treat their origin as a natural element of their identity. A negative message transmitted by the family of origin does not preclude later interest, which, however, is then underpinned by fear and raises many doubts and uncertainties. However, if a particular individual channels them appropriately, they can provide a constructive force, supporting development.

The youngest generation rebuilds the Polish Jewish world their own way, which means that its representatives formulate their own rules, partially selecting, in traditional Judaism, the elements that suit them, and partially giving rise to new traditions. On the one hand, it results from the fact that they had nobody to teach them the determined and binding rules, so they interpret them their own way, and on the other hand, it is an expression of the contemporary approach of young people to religion, which should be adapted to their needs and capabilities, and not subject to rigid principles and values, stipulating what should or has to be done. People from the youngest generation also have a tendency to say: I have origins (41/2/W4) without specifying that these are Jewish origins. This phrase, uttered by many participants, may prove how obvious it is - members of the Jewish community may talk this way with one another, and are accustomed to using such words, but this phrase might also mean something hard to express - participants of such conversations know what they are talking about and do not need to add this 'embarrassing' word. This could result from the fact that older generations have instilled in them a fear of admitting to their background.

Translated by: Mateusz Pazdur

\section{Bibliography}

Breckner R., Kalekin-Fishman D., Miete I., Biographies and the division of Europe: experience, action and change on the 'Eastern side', Leske + Budrich, Opladen 2000.

Cukras-Stelągowska J., Małżeństwa mieszane w społeczności żydowskiej - abberacja czy norma społeczna?, „Wychowanie w Rodzinie”, No. XIV (2/2016), pp. 317-339.

Greenspan H., The Unsaid, the Incommunicable, the Unbearable and the Irretrievable, “Oral History Review”, No. 41/2014, pp. 229-243. 
Inowlocki L., Doing "Being Jewish": Constitution of "Normality" in Families of Jewish Displaced Persons in Germany, [in:] R. Breckner, D. Kalekin-Fishman, I. Miete (eds.), Biographies and the division of Europe: experience, action and change on the 'Eastern side', Leske + Budrich, Opladen 2000.

Krawczyk A., Wielokulturowość oddalona od pogranicza. Na przykładzie doświadczeń biograficznych członków łódzkich stowarzyszeń żydowskich, [in:] A. Rzepkowska (ed.), Odmienność w kulturze, Wydawnictwo Naukowe Uniwersytetu Mikołaja Kopernika, Toruń 2017, p. 141-158.

Mazor A., Tal I., Intergenerational transmission: the individuation process and the capacity for intimacy of adult children of Holocaust survivors, "Contemporary Family Therapy", No. 18/1996, p. 95-113.

Rzepkowska A. (ed.), Odmienność w kulturze, Wydawnictwo Naukowe Uniwersytetu Mikołaja Kopernika, Toruń 2017.

\section{Znaczenie żydowskiej kultury pochodzenia dla żydowskich kobiet $\mathrm{z}$ trzeciego pokolenia}

Streszczenie: Prezentowany artykuł ma charakter badawczy. Powstał na podstawie czterech swobodnych wywiadów z elementami narracji, które przeprowadziłam z przedstawicielami „trzeciej generacji” osób pochodzenia żydowskiego mieszkających w Łodzi. W moim tekście nawiązuję do wiedzy (i braku wiedzy) badanych kobiet na temat ich korzeni. Rozróżniam też dwa stworzone modele rodzinne. Co więcej, umieszczam żydowską kulturę i religię w kontekście ich codziennych doświadczeń.

Słowa kluczowe: kobiety, żydowskie pochodzenie, rodzina, trzecie pokolenie

Nota o autorce: Agnieszka Krawczyk - magister filologii słowiańskiej i pedagogiki; asystentka w Katedrze Badań Edukacyjnych Wydziału Nauk o Wychowaniu; Uniwersytet Łódzki. Zainteresowania naukowe obejmują pedagogikę międzykulturową, kulturę, kulturę żydowską, narratologię, metodologię, badania jakościowe, literaturę, literaturę dziecięcą i młodzieżową. 


\title{
Roksana Pilawska*
}

Uniwersytet Wrocławski

\section{Baśnie jako przestrzeń socjalizacji - na przykładzie baśniowego wizerunku matki}

DOI: 10.25312/2083-2923.15/2019_13rp

\begin{abstract}
Streszczenie: Baśnie, wraz z mitami i przypowieściami biblijnymi, budowały podstawy ludzkiej świadomości. Zostały w nich nagromadzone marzenia i doświadczenia wielu pokoleń. Czy w dzisiejszej rzeczywistości doby Internetu i wszechobecnych mediów, te fantazyjne historie nadal odgrywają istotną rolę w procesie socjalizacji młodego pokolenia? W poniższej pracy próbowałam udzielić odpowiedzi na to pytanie, dokonując analizy archetypowego wizerunku matki w baśni o Kopciuszku i Królewnie Śnieżce. Za teksty źródłowe przyjęłam literackie wersje obu utworów autorstwa braci Grimm oraz opowiadanie Kopciuszek, czyli pantofelek z popielniczki Charlesa Perraulta. Uwzględniając współczesną istotną rolę mediów w procesie inkulturacji społeczeństwa, zdecydowałam się także odwołać do wersji animowanych tych baśni stworzonych przez wytwórnię Walt Disney Company. W celu zaprezentowania odmiennej interpretacji roli macochy w Królewnie Śnieżce odniosłam się również do filmu fabularnego w reżyserii Michaela Cohna pod tytułem Snow White: A Tale of Terror? z 1997 roku. Wedle przyjętych założeń skoncentrowałam się na określeniu roli kontrastu pomiędzy baśniową kochającą matką a niegodziwą macochą w procesie rozwoju i socjalizacji dziecka.
\end{abstract}

Słowa kluczowe: baśń, socjalizacja, wizerunek matki

\section{Wprowadzenie}

Kanon uznawanych norm i wartości jest determinowany przez specyfikę czasów, w których żyjemy. Każdy człowiek niezależnie od miejsca i roku urodzenia, od najmłodszych lat poddawany jest różnorodnym procesom „socjalizacji” - swoistemu treningowi, dzięki któremu w przyszłości będzie mógł swobodnie się poruszać w przestrzeni społecznej. W ramach tego procesu człowiek, przechodząc przez ko-

* Roksana Pilawska - magister, absolwentka studiów pedagogicznych na Wydziale Nauk Historycznych i Pedagogicznych Uniwersytetu Wrocławskiego. Zainteresowania naukowe: pedagogika kultury popularnej; rozwój moralny dziecka, rola kultury w procesie socjalizacji i wychowania dziecka; film animowany; baśń i literatura dziecięca. 
lejne stadia rozwoju, stopniowo wrasta w kulturę grupy, do której przynależy ${ }^{1}$. Wraz z przyswajaniem pewnych doświadczeń, kodów kulturowych i wartości przyswaja także społecznie ustalone schematy i wzorce. W okresie wczesnego dzieciństwa internalizacja owych wartości i norm dokonuje się w oparciu o zarówno osoby najbliższe $\mathrm{w}$ otoczeniu dziecka, jak i elementy szeroko rozumianej kultury, w tym sztukę i media, a zwłaszcza filmy, literaturę oraz baśnie, w których prezentowane są postacie fikcyjne W tym procesie socjalizacji istotną funkcję pełnią baśnie, które przedstawiając i tłumacząc świat w sposób zrozumiały dla dziecka, pomagają mu odnaleźć się w otaczającej je rzeczywistości² ${ }^{2}$ Niektórzy rodzice ignorują jednak znaczenie wychowawcze tego gatunku literackiego, paradoksalnie twierdząc, że zbyt częste obcowanie dziecka z wyimaginowanymi historiami może w przyszłości stać się przyczyną niepowodzeń w realnym życiu ${ }^{3}$. W tym ujęciu edukacyjny potencjał baśni jest ograniczany wyłącznie do walorów estetyczno-literackich. Powstaje więc pytanie, czy baśniowe fabuły to jedynie fantazyjne historie opowiadane dzieciom przed snem, czy może symboliczne opowieści o współczesnej rzeczywistości i złożonej osobowości człowieka? Celem mojego artykułu jest próba wykazania, w jaki sposób baśń za pośrednictwem prezentowanych archetypów i motywów wspomaga emocjonalny i moralny rozwój oraz społeczno-kulturową adaptację dziecka wpisaną w proces socjalizacji.

\section{Baśń w wychowaniu, czyli o socjalizacyjnym potencjale baśni}

Na przestrzeni wieków stanowisko badaczy zajmujących się określeniem roli baśni w procesie wychowania i kształtowania osobowości jednostki ulegało zmianie. Pierwszym utworom o charakterze baśniowym nie przypisywano zbyt dużego znaczenia. Ich funkcja wychowawcza ograniczała się do roli przestrogi przed niedostosowaniem względem uznawanych wartości i norm społecznych. Późniejsze wersje literackie spisane przez wybitnych pisarzy były w większości przeznaczone dla dorosłych odbiorców. Jednak już na przełomie XIX i XX wieku dostrzeżono potencjał baśni we wspomaganiu indywidualnego procesu kształtowania tożsamości najmłodszych czytelników. Stopniowo zaczęto tworzyć opowieści przeznaczone specjalnie dla dzieci, a sam gatunek został określony mianem literatury dziecięcej.

${ }^{1}$ M. Bogunia-Borowska, Gender studies w przedszkolu, „Kultura Popularna”, nr 1(15)/2006, s. 109, za: R. Pilawska, Od Kopciuszka do żony ze Stepford. O archetypowym i disnejowskim wzorcu baśniowej kobiecości, „Teraźniejszość - Człowiek - Edukacja”, nr 3/2018, s. 36.

${ }^{2}$ A. Baluch, Książka jest światem. O literaturze dla dzieci małych oraz dla dzieci starszych i nastolatków, Universitas, Kraków 2005, s. 31.

${ }^{3}$ B. Bettelheim, Cudowne i pożyteczne. O znaczeniach i wartościach baśni, Wydawnictwo W.A.B., Warszawa 1996, s. 194. 
W baśniach zostały zawarte ponadczasowe, uniwersalne wartości moralne i wzorce postępowania ${ }^{4}$. Przez zestawienie kontrastowych postaci przedstawiane historie eksponują różnice pomiędzy dobrem i złem, wspomagając rozwój moralny dziecka, a optymistyczne zakończenia losu bohaterów kształtują w nim potrzebę dążenia do indywidualnego szczęścia. Maria Tyszkowa zwraca uwagę na to, że sugestywne ukazywanie przeciwstawnych cech ludzkich w kreowanych postaciach, takich jak: pracowitość - lenistwo, odwaga - tchórzostwo lub szczodrość - skąpstwo, pomaga dostrzec dziecku wartości pozytywne oraz rozwinąć zdolność do dokonywania poprawnych ocen moralnych zachowania własnego oraz innych ${ }^{5}$. Utożsamianie z baśniowym bohaterem oraz pokonywanie wspólnie z nim trudności i przeszkód ułatwia modelowanie określonych zachowań. Młody odbiorca przez kontakt z baśnią uczy się, jak radzić sobie z własną złością, smutkiem, gniewem czy stresem. Zewnętrzna warstwa baśni jest więc opowieścią o przeżyciach bohaterów, natomiast warstwa głębsza dotyka przeżywanych przez dzieci lęków oraz problemów i zadań rozwojowych ${ }^{6}$. Odpowiednie wyeksponowanie baśniowych wątków i przedstawionych w nich sytuacji może przyczynić się zatem do stopniowego kształtowania stabilności emocjonalnej, związanych z uczuciami postaw moralnych, poczucia empatii oraz lepszego samopoznania własnej osobowości.

Przedstawiona baśniowa rzeczywistość stanowi dla dziecka pierwszą, w pełni zrozumiałą metaforę, w której może ono odnaleźć personifikacje swoich ukrytych marzeń, dążeń i lęków7. W języku potocznym określenia „baśń” i „bajka” często są stosowane zamiennie ${ }^{8}$. Jednak zdaniem Stefanii Wortman, baśń w odróżnieniu od bajki przemawia do emocji, a nie rozumu odbiorcy - przenosząc go w fantastyczny świat

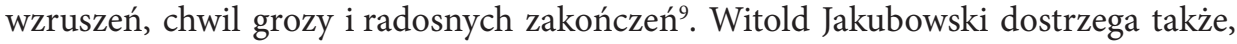
że baśniowa fabuła pozostawia czytelnikowi możliwość dokonania wyboru pomiędzy wyłącznym czerpaniem przyjemności z przebywania w magicznych krainach a samodzielnym odnalezieniem ukrytych wartości ${ }^{10}$. Poprzez przedstawione historie bohaterów baśnie, podobnie jak starożytne mity, opisują otaczający nas świat. Poruszając się pomiędzy fantazyjnymi wątkami, można odnaleźć symboliczne podpowiedzi, jak

${ }^{4}$ E. Konieczna, Baśn w literaturze i filmie. Rola baśni filmowej w edukacji filmowej dzieci w wieku wczesnoszkolnym, Universitas, Kraków 2005, s. 40.

${ }^{5}$ M. Tyszkowa, Baśń i jej recepcja przez dzieci, [w:] H. Skrobiszewska (red.), Baśń i dziecko, Ludowa Spółdzielnia Wydawnicza, Warszawa 1978, cyt. za: tamże, s. 41.

${ }^{6}$ A. Tychmanowicz, Dawno, dawno temu... O roli baśni w wychowaniu i edukacji, „Annales Universitatis Mariae Curie-Skłodowska, sectio J - Paedagogia-Psychologia”, nr 3/2018, s. 103.

7 B. Bettelheim, dz. cyt., s. 84.

${ }^{8}$ J. Krzyżanowski, W świecie bajki ludowej, Państwowy Instytut Wydawniczy, Warszawa 1980, s. 29.

9 S. Wortman, Baśń w literaturze i życiu dziecka. Co i jak opowiadać?, Stowarzyszenie Bibliotekarzy Polskich, Warszawa 1958, s. 12-13.

${ }_{10}$ W. Jakubowski, Edukacja i kultura popularna, Oficyna Wydawnicza Impuls, Kraków 2001, s. $58-59$. 
poprawnie funkcjonować w danej grupie społecznej. Baśniowe historie są nieodłącznym elementem kultury danego społeczeństwa, wspomagającym proces adaptacji jednostki. Najważniejszą zaletą baśni w aspekcie socjalizacji jest jej uniwersalność. Pomimo odgórnie przyjętej interpretacji treści - eksponującej uznawane społecznie normy i wartości - dla każdego znaczenie baśniowych historii będzie nieco odmienne w zależności od płci, wieku, cech charakteru i doświadczeń.

Od lat 70. ubiegłego wieku baśnie stały się także przedmiotem zainteresowań psychologów. W badaniach nad znaczeniem tego gatunku literackiego przełomowe okazały się publikacje Bruno Bettelheima, który dokonał analizy baśni z perspektywy psychodynamicznej, ukazując ich wychowawcze i terapeutyczne znaczenie ${ }^{11}$. Według autora, baśnie pobudzają ciekawość i wyobraźnię dziecka poprzez nadawanie nowego, magicznego znaczenia prezentowanym postaciom i przedmiotom użytkowym. Baśnie wspomagają intelektualno-moralny rozwój dzieci, symboliczne nawiązując do ich problemów i pragnień. Przekazywane w nich fantazyjne treści pomagają młodym czytelnikom zrozumieć to, co dzieje się zarówno w świadomej, jak i nieświadomej sferze ich osobowości. Za pomocą metaforycznych historii baśnie wskazują sposoby rozwiązania napotykanych trudności i problemów. Nawiązują jednocześnie i w takim samym stopniu do wszystkich aspektów osobowości młodego czytelnika ${ }^{12}$. Z powyżej wymienionych względów, dokonując analizy popularnych wątków baśniowych, chciałabym również odwołać się do teorii B. Bettelheima i jego psychoanalitycznej interpretacji znaczeń motywów baśniowych.

\section{Geneza baśniowego archetypu macochy}

Każda stworzona fantazyjna opowieść jest na swój sposób oryginalna i wyjątkowa bez względu na genezę wątku baśniowego. Fabuła baśni posiada jednak pewne powtarzalne motywy. W kanonie literatury baśniowej można znaleźć wiele opowieści o pięknej dziewczynie uwięzionej w zamku i walecznym rycerzu, który aby zwrócić jej wolność, musi pokonać złego smoka. Prezentowane w baśniach schematyczne postacie eksponują proste, powtarzalne wzorce zachowań, kreując jednocześnie ramowy model odgrywanej roli. Wywodzące się z historii i tradycji określone normy, wartości i wzory funkcjonują w rzeczywistości kulturowej, symbolicznie werbalizując się mię$\mathrm{dzy}$ innymi w literaturze ${ }^{13}$. Te podświadomie utrwalone i często stereotypowe obrazy wynikają ze społecznie przyjętych schematów, kodów kulturowych i wartości uznawanych przez dane społeczeństwo ${ }^{14}$. Twórca pojęcia „nieświadomości zbiorowej” Carl Gustaw Jung uważał, że każda grupa społeczna posiada pewne przekonania, wy-

\footnotetext{
11 A. Tychmanowicz, dz. cyt., s. 103.

12 B. Bettelheim, dz. cyt., s. 35, za: R. Pilawska, dz. cyt., s. 36.

13 E. Konieczna, dz. cyt., s. 18.

14 Tamże.
} 
obrażenia o świecie i doświadczenia tkwiące w zbiorowej podświadomości. Wszelkie wspomnienia rodzaju ludzkiego wchodzące w skład dziedzictwa kulturowego każdego człowieka, zawierające wspólne, dziedziczone wzorce zachowań badacz określił mianem „archetypów” (grec. archetypon - pierwowzór). Archetypy przejawiają się jako symbole lub personifikacje, a ich treść wyrażana jest w formie metafory. Koncepcję archetypu C.G. Jung wywnioskował przede wszystkim z obserwacji. Zauważył, że we wszystkich mitach lub wywodzących się z nich baśniach - niezależnie od kultury, w której występują - obecne są pewne wspólne motywy. Tkwiąc w podświadomości zbiorowej, mają wpływ na społeczeństwo, w którym funkcjonują, na to, jak ono postrzega i interpretuje otaczający świat ${ }^{15}$. Wspomniane schematy są werbalizowane i konkretyzowane w kulturze, a przede wszystkim w literaturze przez symbole i archetypy literackie. Jednym z najbardziej popularnych archetypów literatury dziecięcej przekazującym czytelnikom ukryte treści jest postać złej macochy.

Zły charakter personifikowany w postaci niegodziwej i niesprawiedliwej względem pasierbicy kobiety funkcjonuje w przekazach ludowych od niepamiętnych czasów. W jednym z hinduskich poematów sprzed 2000 lat zatytułowanym Ramajan można odnaleźć historię królewicza Ramy, który zostaje zmuszony do ucieczki w gęstwiny niebezpiecznej puszczy przed zawistną drugą żoną ojca ${ }^{16}$. Negatywna postać macochy funkcjonowała w przekazie ustnym przez stulecia, by w końcu na dobre zadomowić się zarówno w twórczości francuskiego baśniopisarza epoki baroku Charles’a Perraulta, jak i spisanych utworach autorstwa Jakuba i Wilhelma Grimmów. W większości baśni wywodzących się ze starożytnych mitów i kultury ludowej postać macochy jest nacechowana negatywnie - dlaczego tak jest? Czy jej obecność ma za zadanie spełnić jedynie swoją archaiczną funkcję i zastraszyć młodych czytelników? Czy wprowadzenie tak zwanego czarnego charakteru ma na celu wyłącznie wyeksponowanie zalet dobrej postaci oraz zwiększenie atrakcyjności utworu w oczach dziecka?

Powierzchownie interpretując najbardziej popularne baśnie, można stwierdzić, że w żadnym innym gatunku literackim problem dobra i zła nie jest tak wyraźnie zarysowany ${ }^{17}$. W późniejszych baśniowych utworach niegodziwość jest równie wszechobecna, jak cnota. Dodatkowo, baśniowe kreacje złych bohaterów są w aspekcie poznawczym bardzo interesujące dla dziecka, gdyż często cechuje je nieprzeciętna uroda lub nadprzyrodzone moce. W trakcie rozwoju fabuły zła postać niejednokrotnie zyskuje chwilową przewagę nad dobrą. Powyższe argumenty mogłyby więc służyć jako potwierdzenie powyżej opisanego stanowiska o ograniczeniu roli negatywnego bohatera do funkcji kontrastu dla zalet i cnót pozytywnej postaci. Istotny jest jednak fakt, że na końcu każdej baśniowej opowieści bohaterowie prezentujący negatywne wartości zostają w mniejszym lub większym stopniu ukarani - to symboliczne zakończenie może

15 C.G. Jung, Archetypy i symbole. Pisma wybrane, za: tamże.

16 S. Wortman, dz. cyt., s. 15.

17 E. Ptaszyńska, Znaczenie bajki oraz baśni w życiu dziecka, http://www.czytanie.pl/index. php?strona=008/basnie (dostęp: 16.12.2015). 
mieć znaczenie w kontekście kształtowania postaw moralnych młodych odbiorców. Istnieją więc podstawy, by sformułować tezę, że postać niegodziwej macochy posiada głęboki, choć ukryty sens w aspekcie socjalizacyjno-edukacyjnym. Chciałabym rozważyć prawdziwość tego stwierdzenia na podstawie analizy i interpretacji dwóch popularnych wątków baśniowych, wywodzących się z kultury ludowej: o Kopciuszku i Królewnie Śnieżce.

Powyżej wymienione postacie baśniowe należą do kanonu literatury dziecięcej. W celu wykazania obecnych w ich strukturze motywów i schematów starałam się odnaleźć i przeanalizować różne warianty tych ponadczasowych opowieści. Za teksty źródłowe do analizy przyjęłam literackie wersje obu baśni autorstwa braci Grimm oraz wersję Kopciuszka znanego bardziej jako Kopciuszek, czyli pantofelek z popielniczki autorstwa Ch. Perraulta. Wychodząc z założenia, że współczesne media pełnią istotną funkcję w procesie inkulturacji młodego pokolenia, zdecydowałam się także uwzględnić pełnometrażowe wersje animowane tych baśni stworzone przez wytwórnię Walt Disney Company. W celu zaprezentowania odmiennej interpretacji roli macochy w Królewnie Śnieżce chciałabym również odnieść się do filmu fabularnego w reżyserii Michaela Cohna pod tytułem Snow White: A Tale of Terror? (polskie tłumaczenie tytułu: Śnieżka dla dorosłych) z 1997 roku. Produkcja ta - choć przeznaczona dla dorosłych odbiorców - wyraźnie nawiązuje do oryginalnej, współcześnie zapomnianej literackiej wersji tekstu braci Grimm. Podczas dokonywania analizy i interpretacji chciałabym skoncentrować się na sposobie przedstawienia baśniowych postaci kobiecych oraz specyfice relacji pomiędzy nimi.

\section{Matka versus macocha, czyli o roli kontrastu}

W grimmowskiej wersji Kopciuszka, od którego chciałabym zacząć swoją analizę, postacie zmarłej matki dziewczyny i macochy są przedstawione na zasadzie wcześniej wspominanego bardzo wyraźnego kontrastu. Druga żona ojca upokarzała pasierbicę nie tylko poprzez powierzanie domowych obowiązków oraz zlecanie tych niewykonalnych, ale także przez sprawną manipulację ojcem dziewczyny. Pan domu wcześniej wyrozumiały i dobroduszny dla córki - pod wpływem młodej żony nagle przestał ją zauważać. Jego zachowanie można interpretować jako symboliczne pozbawienie wolnej woli, utożsamiane $\mathrm{z}$ magicznym opętaniem przez niegodziwą kobietę. Macocha nie reagowała także na złe traktowanie dziewczyny przez przybrane siostry. Jej zachowanie przejawiało zazdrość o urodę, młodość i wcześniejszą wysoką pozycję społeczną dziewczyny.

Zachowując baśniową zasadę konstruowania rysów charakterologicznych postaci $\mathrm{w}$ formie zestawiania przeciwstawnych cech, zmarła matka Kopciuszka przedstawiona jest natomiast jako spokojna i wrażliwa kobieta, która nawet na łożu śmierci przekazuje ukochanej córce uniwersalne wartości i wskazówki dotyczące dalszego postępowania dziewczyny. Wypowiadając te słowa w tak znaczącym momencie - 
wzmacnia ich przekaz, przez co Kopciuszek mimo późniejszych niepowodzeń nie przestał wierzyć $\mathrm{w}$ wizję sprawiedliwego świata ${ }^{18}$. W trakcie rozwoju baśniowej fabuły zmarła kobieta nadal symbolicznie opiekuje się ukochaną córką za pośrednictwem przyrody (zgodnie z wersją braci Grimm) lub pod postacią dobrej wróżki (przyjmując wersję Perraulta i Walta Disneya). W przypadku pierwszej wersji podlewanie łzami krzaku leszczyny na grobie matki można interpretować jako wyraz ogromnej tęsknoty i miłości dziewczyny względem zmarłej.

Wyżej przedstawiony kontrast pomiędzy tymi dwiema postaciami - które pomimo różnic charakterologicznych odgrywają podobną rolę względem Kopciuszka w kontekście społecznym - można interpretować z punktu widzenia psychoanalizy. Według Bruna Bettelheima baśnie:

[...] przyjmują psychoanalityczny model osobowości ludzkiej, kierując przekazy do świadomej, podświadomej i nieświadomej sfery umysłu niezależnie od tego na jakim poziomie każda $\mathrm{z}$ tych sfer funkcjonuje u człowieka ${ }^{19}$.

Małgorzata Wójcik-Dudek twierdzi także (powołując się na teorię rozwoju moralnego Jeana Piageta), że podczas okresu „edypalnego” w umyśle dziewczynki matka jest rozszczepiona na dwie przeciwstawne osobowości: dobrej i kochającej opiekunki z okresu „przededypalnego” oraz złej, niegodziwej macochy będącej podświadomą odpowiedzią na aktualne wewnętrzne problemy dziecka ${ }^{20}$. Ówczesne wyobrażenia dziewczynki odzwierciedla baśniowa fabuła. W mojej opinii, odnosi się to jednak jedynie do literackiej wersji utworu.

W wyżej wspominanym filmie animowanym o Kopciuszku śmierć matki oraz znacząca rola ojca w dramatycznym losie dziewczyny są pomijane. Dodatkowo, w przygotowaniach do królewskiego balu pomocna okazuje się nie tylko dobra wróżka, ale także zaprzyjaźnione myszki. Oczywiście, mimo iż jest to pewne fabularne nawiązanie do literackiej wersji Perraulta, to jednak nie można przeoczyć - charakterystycznego dla produkcji wytwórni - „spłaszczenia” zarówno fabuły, jak i psychologicznej głębi prezentowanych postaci. Sam bal, stanowiący przełom w losach bohaterki, prezentowany jest symbolicznie jako pojedyncze wydarzenie z pominięciem istotnego motywu trzech prób i związanej z tym stopniowej wewnętrznej przemiany osobowości dziewczyny. Modyfikacja ta może stanowić jednak naturalną konsekwencję próby adaptacji literackiego wątku baśniowego wywodzącego się z kultury ludowej do potrzeb audiowizualnego medium przez przemysł rozrywkowy. W charakterystycznej konstrukcji fabuły filmu animowanego istotny może być także okres powstania filmu, określający ówcześnie wyznawane normy społeczno-kulturowe

${ }^{18}$ M. Wójcik-Dudek, Archetyp, baśń... O (nie)szkolnym alfabecie baśni, [w:] H. Synowiec (red.), Z teorii i praktyki dydaktycznej języka polskiego, Wydawnictwo Uniwersytetu Śląskiego, Katowice 2014, s. 30.

19 B. Bettelheim, dz. cyt., s. 43.

${ }^{20}$ M. Wójcik-Dudek, dz. cyt., s. 30. 
i przekonania odnośnie do ról społecznych wynikających z przynależności płciowej. Sprowadzenie fabuły do prostego schematu: uratowania pracowitej i dobrej dziewczyny przez pięknego i bogatego księcia, odzwierciedla konserwatywny obraz podziału ról życiowych i społecznej pozycji kobiety uznawany za wzór w latach 50 . XX wieku.

Myśląc o motywie macochy w literaturze dziecięcej, nie można pominąć historii o dziewczynie „Z włosami czarnymi jak heban, cerą białą jak śnieg i ustach czerwonych niczym krew" - o Królewnie Śnieżce. W tej baśni macocha przyjmuje także rolę niedoszłej morderczyni, mrocznej czarownicy i władczej królowej. Po nieudanej próbie zamordowania królewny przez myśliwego próbuje tego dokonać samodzielnie za pośrednictwem magii. Najpierw przebierając się za handlarkę, namawia królewnę do włożenia gorsetu. Następnie jako poczciwa staruszka ofiarowuje Śnieżce zatruty grzebień. Na końcu udając wieśniaczkę, namawia naiwną dziewczynę do skosztowania magicznego jabłka. Tak samo jak w historii o Kopciuszku baśń opiera się więc na wędrownym motywie trzech prób, podczas których baśniowa postać jest coraz bardziej zdeterminowana, by osiągnąć zamierzony cel. Użyte przez czarownicę magiczne przedmioty mają tutaj kluczowe znaczenie. Każdy z nich jest kulturowym symbolem - atrybutem kobiecości i urody zewnętrznej. Ich zastosowanie wskazuje, że motywem działań macochy jest zazdrość o urodę dziewczyny i próba wyeliminowania rywalki o miano najpiękniejszej. Ocenianie zachowania królowej przez pryzmat próżności pomaga czytelnikom w dokonaniu osądu moralnego. Schematyczne myślenie narzuca także zajmowana przez nią pozycja społeczna, która zdaniem Bettelheima może świadczyć o metaforycznym zakończeniu wewnętrznych przemian jej osobowości ${ }^{21}$. Królowa, będąc na szczycie hierarchii społecznej, osiągnęła już sukces życiowy - chęć zabicia Śnieżki może być więc przejawem wygórowanych ambicji lub rządzy władzy absolutnej. Desperacja przejawiana w jej zachowaniu może sugerować również, że królowa, przyzwyczajona do posłuchu innych i poczucia kontroli z racji pełnionej funkcji, pragnie symbolicznie zapanować także nad upływem czasu i naturalnym procesem starzenia poprzez zachowanie miana najpiękniejszej.

W odniesieniu do adaptacji animowanej moje spostrzeżenia są identyczne, jak w przypadku disnejowskiego Kopciuszka - postanowiłam więc pominąć szczegółowe opisywanie tej wersji. Jednak by nadać postaci macochy nieco psychologicznej głębi, chciałabym teraz przejść do interpretacji tego archetypu baśniowego we wspomnianym filmie fabularnym pod tytułem Śnieżka dla dorostych. Początkowo ta historia nie różni się niczym od popularnej baśniowej wersji. Matka Śnieżki umiera tragicznie podczas porodu, a zrozpaczony ojciec po kilku latach samotności żeni się ponownie $\mathrm{z}$ tajemniczą księżną. Od tego momentu fabuła filmu jest jednak uzupełniona o wątki tłumaczące późniejsze postępowanie macochy względem pasierbicy. Królowa od samego początku stara się zdobyć sympatię małej królewny, jednak dziewczynka, będąc zazdrosna o względy ojca, udaremnia jej starania. Młodą Śnieżkę cechują zachowania

${ }^{21}$ B. Bettelheim, dz. cyt., s. 320 . 
charakterystyczne dla wcześniej opisywanego okresu edypalnego. Po kilku latach królowa zachodzi w upragnioną ciążę, jednak na skutek złego traktowania przez pasierbicę traci dziecko. Jest to symboliczny początek jej przemiany. W tej wersji magiczne moce macochy są przedstawione jako konsekwencja jej psychicznego obłędu - rozpaczy po śmierci ukochanego synka. Przedmiotem symbolizującym jej stan psychiczny jest magiczne zwierciadło, przedstawiające przerysowany obraz rzeczywistości. To właśnie tajemnicze lustro stopniowo namawia królową do zamordowania królewny. Zrozpaczona kobieta początkowo nie chce dokonać tego czynu, jednak z czasem poddaje się mrocznej mocy zwierciadła. Od tego momentu akcja filmu toczy się klasycznym, grimmowskim torem. Początek historii powoduje jednak, że postać macochy przybiera bardziej ludzki wymiar. Filmowa królowa nie jest tylko zazdrosną, próżną kobietą, ale także skrzywdzoną i doprowadzoną do obłędu matką. Psychoanalityczny rozłam baśniowych postaci na kochającą matkę i niegodziwą macochę odzwierciedla się w jednej złożonej osobowości bohaterki. Tę psychologiczną dwubiegunowość królowej ilustrują także przyodziewane przez nią stroje. Podczas królewskiego balu macocha ma na sobie krwistoczerwoną suknię z białymi elementami. Przyjmując (zgodnie z kodami kulturowymi), że kolor biały symbolizuje czystość i niewinność, a czerwony - krew i namiętność, strój może oznaczać wewnętrzną walkę kobiety pomiędzy wrodzoną dobrocią a obezwładniającym ją szaleństwem. Oczywiście, wyżej przedstawione argumenty nie tłumaczą w pełni zachowania macochy, jednak z pewnością moralna ocena jej postępowania nie jest już tak prosta jak w przypadku wcześniej opisanych baśniowych i animowanych wersji.

\section{Baśniowe postacie kobiece w perspektywie społeczno-kulturowej}

Kontynuując powyższą analizę, można wywnioskować, że oba wątki baśniowe poruszają temat funkcjonowania kobiet w kulturze i rzeczywistości społecznej. Piękność, cechująca baśniowe bohaterki, jest utożsamiana z kobiecością ${ }^{22}$. W baśniowej hierarchii istnieje wyraźny związek pomiędzy urodą zewnętrzną a pozycją kobiet w społeczeństwie. Wyjaśnia to prezentowaną próżność bohaterek, które poprzez dbałość o wygląd i aparycję próbują dowieść swojej kulturowej wartości. Królewna Śnieżka daje się przekonać Złej Królowej do kupna gorsetu i grzebienia, a zazdrosna o urodę Kopciuszka macocha próbuje wpłynąć na jej wygląd zewnętrzny, zlecając jej ciężkie prace domowe i zmuszając do noszenia zniszczonych, brudnych ubrań. Kopciuszek również ma świadomość, że bez odpowiedniej oprawy i kosztownego stroju nie zdobędzie miłości księcia.

${ }_{22}$ A. Woźniak, Wizerunek kobiety w baśniach, jej rola i znaczenie, http://hamlet.edu.pl/wozniak-kobiety-w-basniach (dostęp: 16. 12.2017). 
Uroda i młodość łączą się także z płodnością bohaterek. W filmowej wersji królowa popada w obłęd, gdy na skutek utraty dziecka nie może w przyszłości posiadać potomstwa. W baśniowym świecie kobieta posiada więc wartość tylko przez określony czas - pomiędzy dzieciństwem a starością ${ }^{23}$. Macocha zaczyna nienawidzić Śnieżkę dopiero w momencie, gdy dziewczyna, wchodząc w okres dojrzewania, może stać się potencjalną konkurentką w rywalizacji o względy mężczyzn. W przebraniu staruszki czarownica zdobywa zaufanie królewny, ponieważ nie stanowi dla niej realnego zagrożenia w świecie wymiany społecznej.

Kolejnym zauważalnym motywem występującym w obu baśniach jest płynne przechodzenie kobiecych bohaterek z realnej rzeczywistości do świata magii. Kopciuszek kontaktuje się ze swoją zmarłą matką za pośrednictwem magicznego krzaku leszczyny, a w innej wersji do balu przygotowuje ją dobra wróżka. W Królewnie Śnieżce same narodziny dziewczynki mają charakter magiczny - symboliczne ukłucie w palec można porównać do czarów i magicznych rytuałów, za sprawą których królowa spełnia swe pragnienia. Na późniejszym etapie fabuły przyczyną niepowodzeń królewny jest natomiast magiczne zwierciadło i mroczne moce macochy.

\section{Podsumowanie}

W wyżej opisanych wersjach baśniowych wątków archetypowe postacie kobiece są bardzo mocno zarysowane, przeważnie na zasadzie kontrastu. Ta specyficzna cecha baśniowej rzeczywistości pomaga dzieciom (zwłaszcza w okresie przedszkolnym) zrozumieć złożoną osobowość człowieka. Próbując wytłumaczyć niespójne zachowania ludzi, dziecko często rozbija ich osobowość na dwie postacie ${ }^{24}$. Gdy zachowanie osoby dla niego znaczącej staje się nagle negatywne lub niezrozumiałe, podświadomie utożsamia ją ze złym bohaterem. Jeśli natomiast w krótkim czasie ulegnie ono zmianie i znów stanie się pozytywne, dziecko odpowiednio kojarzy ją z pozytywną postacią. W ten sposób ich emocjonalny stosunek do osób bliskich nie jest zagrożony i nie ulega gwałtownym zmianom. Ówczesne wyobrażenia dziecka odzwierciedlają właśnie baśniowe fabuły, kreując odpowiednio postać dobrej wyrozumiałej matki i okrutnej macochy. Obserwowany w baśniach podział na bohaterów prezentujących skrajne postawy moralne zostaje podświadomie przeniesiony przez dziecko do życia codziennego i własnych niepowodzeń. Ten rozłam trwa do momentu, gdy młody odbiorca będzie w stanie w pełni zrozumieć i zaakceptować swoją osobowość wraz z możliwością ewentualnego popełnienia błędu. W tym przypadku motyw macochy

${ }^{23}$ O. Siara, M. Wierzbicka, Analiza strukturalna Kopciuszka i Królewny Śnieżki, http://www. antropologia.isns.uw.edu.pl/?page id=60 (dostęp: 16.02.2017).

${ }^{24} \mathrm{~K}$. Krasoń, Baśniowe odkrywanie znaczeń jako wspomaganie rozwoju dziecka, [w:] J. Papuzińska, G. Leszczyński (red.), Kultura literacka dzieci i młodzieży u progu XXI wieku, Wydawnictwo CEBiD, Warszawa 2002, s. 140. 
również może okazać się pomocny. W finale baśni o Kopciuszku nie ma dopowiedzenia o dalszych losach złej macochy. To otwarte zakończenie historii może sugerować młodszym czytelnikom, że otrzymała ona drugą szansę pomimo wcześniejszych uczynków. Wykorzystanie w baśniach archetypowej postaci macochy nie tylko pomaga dzieciom w procesie adaptacji społecznej i rozwoju moralnego, ale także może pozytywnie nastawiać je na przyszłość.

Podsumowując, baśń przemawia do dziecka językiem symbolicznych obrazów, w których przyjęty porządek społeczno-kulturowy zostaje odzwierciedlony. Utworzony za ich pośrednictwem wewnętrzny obraz świata nie jest zazwyczaj poddawany indywidualnej refleksji lub późniejszej reinterpretacji. Raz przyjęte przez jednostkę normy i wartości są uznawane przeważnie bezkrytycznie za właściwe ${ }^{25}$. Poprzez ich internalizację młody człowiek stopniowo kształtuje swoją indywidualną tożsamość, przyjmując tym samym określone prawa, obowiązki oraz oczekiwania wynikające z odgrywanych ról społecznych.

\section{Bibliografia}

Baluch A., Książka jest światem. O literaturze dla dzieci małych oraz dla dzieci starszych i nastolatków, Universitas, Kraków 2005.

Bettelheim B., Cudowne i pożyteczne. O znaczeniach i wartościach baśni, Wydawnictwo W.A.B., Warszawa 1996.

Bogunia-Borowska M., Gender studies w przedszkolu, „Kultura Popularna”, nr 1(15)/ 2006.

Jakubowski W., Edukacja i kultura popularna, Oficyna Wydawnicza Impuls, Kraków 2001.

Jung C.G., Archetypy i symbole. Pisma wybrane, Wydawnictwo Czytelnik, Warszawa 1976.

Konieczna E., Baśń w literaturze i filmie. Rola baśni filmowej w edukacji filmowej dzieci w wieku wczesnoszkolnym, Universitas, Kraków 2005.

Krasoń K., Baśniowe odkrywanie znaczeń jako wspomaganie rozwoju dziecka, [w:] J. Papuzińska, G. Leszczyński (red.), Kultura literacka dzieci i młodzieży u progu XXI wieku, Wydawnictwo CEBiD, Warszawa 2002.

Krzyżanowski J., W świecie bajki ludowej, Państwowy Instytut Wydawniczy, Warszawa 1980.

Pilawska R., Od Kopciuszka do żony ze Stepford. O archetypowym idisnejowskim wzorcu baśniowej kobiecości, „Człowiek - Teraźniejszość - Edukacja”, nr 3(83)/2018.

${ }^{25}$ M. Bogunia-Borowska, dz. cyt., s. 109. 
Ptaszyńska E., Znaczenie baśni oraz bajki w życiu dziecka, http://www.czytanie.pl/index.php?strona=008/basnie (dostęp: 16.12.2015).

Siara O., Wierzbicka M., Analiza strukturalna Kopciuszka i Królewny Śnieżki, http:// www.antropologia.isns.uw.edu.pl/?page id=60 (dostęp: 16.02.2017).

Tychmanowicz A., Dawno, dawno temu... O roli baśni w wychowaniu i edukacji, „Annales Universitatis Mariae Curie-Skłodowska, sectio J - Paedagogia-Psychologia", nr 3(31)/2018.

Tyszkowa M., Baśń i jej recepcja przez dzieci, [w:] H. Skrobiszewska (red.), Baśń i dziecko, Ludowa Spółdzielnia Wydawnicza, Warszawa 1978.

Wortman S., Baśń w literaturze i życiu dziecka. Co i jak opowiadać?, Stowarzyszenie Bibliotekarzy Polskich, Warszawa 1958.

Woźniak A., Wizerunek kobiety w baśniach, jej rola i znaczenie, http://hamlet.edu.pl/ wozniak-kobiety-w-basniach (dostęp: 16.02.2017).

Wójcik-Dudek M., Archetyp, baśń... O (nie)szkolnym alfabecie baśni, [w:] H. Synowiec (red.), $Z$ teorii i praktyki dydaktycznej języka polskiego, Wydawnictwo Uniwersytetu Śląskiego, Kraków 2014.

\section{Fairytales as a space for socialization - on the example of a fairytale image of the mother}

Abstract: Fairytales, along with myths and biblical parables, have built the foundation of human consciousness. The dreams and experiences of many generations have been accumulated. Do these stories continue to play an important role in the socialisation of the younger generation in today's reality of the Internet and ubiquitous media? This paper attempts to answer this question by analysing the archetypal image of the mother in two fairytales - Cinderella and Snow White. The literary versions of the two fairytales by the Brothers Grimm, and "Cinderella" by Charles Perrault, served as the source texts. Taking into consideration the important role of contemporary media in the process of inculturation of society, I decided to include the animated versions of these fairytales created by the Walt Disney Company. To show a different interpretation of the role of stepmother, I referred to Michael Cohn's feature film "Snow White: A Tale of Terror?" (1997). I focused on determining the role of the contrast between the fairytale loving mother and the wicked stepmother in children's development and in the socialisation process.

Keywords: fairytales, socialization, image of the mother

About the author: Roksana Pilawska - a graduate of Master's studies, graduate of pedagogical studies at the Faculty of Historical and Pedagogical Sciences (University of Wroclaw). Research interests: pedagogy of popular culture; moral development of children, the role of culture in the process of socialisation and upbringing of children, animated film; fairytale and children's literature. 


\title{
Jeden uniwersytet a dwa światy - analiza porównawcza koncepcji studiowania
}

DOI: 10.25312/2083-2923.15/2019_03pb

\begin{abstract}
Streszczenie: Artykuł przedstawia koncepcje studiowania studentów pedagogiki i romanistyki Uniwersytetu Gdańskiego. Przeprowadzono badania fenomenograficzne na podstawie wywiadów semi-strukturyzowanych. Pomimo pokrewności kierunków wyłoniły się różnice w ich koncepcjach. Poza spodziewanym stanowiskiem głoszącym, że studiowanie to przygotowanie do pracy, pojawiły się podejścia zaskakujące, np. studiowanie jako poniżanie czy studiowanie jako czekanie. Autorka tekstu to absolwentka obu badanych wydziałów.
\end{abstract}

Słowa kluczowe: studiowanie, koncepcje studiowania, Uniwersytet Gdański, pedagogi$\mathrm{ka}$, romanistyka

\section{Wprowadzenie}

Niniejszy tekst ma na celu przedstawienie wyników badań przeprowadzonych na Uniwersytecie Gdańskim, które opisują to, w jaki sposób studenci tego uniwersytetu postrzegają „studiowanie” i w jakim stopniu ich koncepcje studiowania różnią się na dwóch kierunkach o spokrewnionych specjalizacjach: pedagogiki na Wydziale Nauk Społecznych oraz filologii romańskiej ze specjalizacją nauczycielską na Wydziale Neofilologicznym. Powodem podjęcia się przeprowadzenia tych badań było spostrzeżenie przez autorkę różnic w funkcjonowaniu studenta na wymienionych kierunkach Uniwersytetu Gdańskiego.

* Paulina Białka - magister pedagogiki, doktorantka w Instytucie Pedagogiki Uniwersytetu Gdańskiego; zainteresowania badawcze: jakość kształcenia, kultury uniwersyteckie, współczesny uniwersytet. 


\section{Materiały i metody}

Studiowanie jest dość często podejmowanym tematem rozważań naukowych. Dla przykładu warto przytoczyć kilka publikacji, z którymi się zapoznałam przed przystąpieniem do badań: Studiowanie w meandrach życiowych wyborów, red. nauk. Dorota Ciechanowska, Szczecin 2012; Student i studiowanie bezpieczeństwa: badania rekonesansowe: raport końcowy, red. Marian Lutostański, Olsztyn 2015, czy też Studiowanie w Polsce Białorusinów polskiego pochodzenia: psychospołeczne aspekty procesów i ich skutków, Paweł Juszkiewicz, UMK, Toruń 2016. Coraz częściej bada się podejście studentów do studiowania oraz do wyższego wykształcenia. Współcześnie społeczeństwo uważa, że zdobycie wykształcenia wyższego na uczelni publicznej, a zwłaszcza na kierunkach o charakterze technicznym ${ }^{1}$, podnosi szansę na prowadzenie lepszego życia w przyszłości dzięki łatwiejszemu objęciu dobrze płatnego stanowiska.

Obranie koncepcji studiowania jako przedmiotu badań przeprowadzonych na dwóch wydziałach Uniwersytetu Gdańskiego miało za zadanie wskazać cechy przypisywane temu zagadnieniu współcześnie oraz wyeksponować jego silne i słabe strony. Władze uniwersyteckie dążą do podniesienia jakości kształcenia. Na Uniwersytecie Gdańskim badanie jakości kształcenia odbywa się przy wykorzystaniu ilościowych narzędzi pomiaru w postaci elektronicznych anonimowych ankiet przeprowadzanych wśród studentów i kadry akademickiej, które skupiają się na analizie odczuwanej satysfakcji z określonych zajęć dydaktycznych. Ograniczenie się do takiego ilościowego - podejścia nie daje szansy na pogłębioną analizę różnych kulturowo zapośredniczonych uwarunkowań studiowania - stąd też zaistniała potrzeba studiów wchodzących w głąb omawianego zjawiska. Podjęte zostały badania interpretatywne, ponieważ zwracają one uwagę badaczy na lokalność uzyskiwanej wiedzy, podkreślają ważność narracji, wskazują na szkodliwość niedostrzegania osobliwości świata społecznego oraz dają możliwość postawienia innego niż zakorzeniony w pragmatyce skuteczności celu badania naukowego ${ }^{2}$.

Podstawę badań stanowiły wywiady przeprowadzone ze studentami filologii romańskiej oraz pedagogiki. Miały to być swobodne rozmowy spełniające zasady wywiadu semi-strukturyzowanego ${ }^{3}$. Po dwóch pierwszych wywiadach okazało się jednak, że należy przygotować się również na inną okoliczność. Nie wszyscy studenci byli gotowi na swobodną narrację dotyczącą tego, czym dla nich jest studiowanie. W związku z zaistniałą sytuacją drugim wariantem były dyspozycje do wywiadu, w których zakreślone zostały jedynie te kategorie, które interesowały badaczkę (na-

${ }_{1}$ Zob. Studia wyższe - dla kogo, po co i z jakim skutkiem, komunikat z badań BS/92/2013, CBOS, Warszawa, lipiec 2013.

2 T. Bauman, Poznawczy status danych jakościowych, [w:] J. Piekarski, D. Urbaniak-Zając, K.J. Szmidt (red.), Metodologiczne problemy tworzenia wiedzy w pedagogice. Oblicza akademickiej praktyki, Oficyna Wydawnicza Impuls, Kraków 2010, s. 91-106.

${ }^{3}$ S. Kvale, Interviews. Wprowadzenie do jakościowego wywiadu badawczego, Trans Humana, Białystok 2004, s. 13-88, 164-232. 
uka, edukacja w uniwersytecie, stosunek studentów do wykładowców i vice versa, sposób sprawdzania wiedzy oraz prowadzenia zajęć itp.). Wszystkie rozmowy poddane zostały transkrypcji oraz analizie pod kątem fenomenografii komparatywnej. Po tym dokonano wtórnej analizy tych danych za pośrednictwem matrycy Raymonda V. Padilli ${ }^{4}$ a następnie krytycznej analizy dyskursu.

Jako że oba objęte badaniem kierunki można, a nawet należy zaliczyć do nauk humanistycznych i społecznych, wydawać by się mogło, że studiowanie na każdym z nich nie będzie się specjalnie różniło i będzie przybierało normalne i powszechne formy. Przechodząc jednak z jednego wydziału na drugi, okazuje się, że nie wszędzie student jest traktowany w podobny sposób. Już po wstępnych wywiadach widać było, że na Wydziale Nauk Społecznych kultura studiowania jest zupełnie inna od tej rozpowszechnionej na Wydziale Neofilologicznym. Jak wcześniej wspomniano, próbą badawczą byli studenci dwóch kierunków: romanistyki oraz pedagogiki. Dobór próby był więc celowy ze względu na przyjęty przedmiot badań. Wszystkie osoby, z którymi przeprowadzono wywiady, były aktualnymi lub „świeżo upieczonymi” absolwentami tych kierunków w różnych trybach studiowania: stacjonarnym, niestacjonarnym, studenci korzystający z systemu ITS (indywidualny tok studiów), a także ci, dla których nie był to jedyny kierunek studiów. Wśród badanych z Wydziału Neofilologicznego często pojawiało się pytanie o to, czy rozmowa będzie anonimowa i czy ich nazwiska nie pojawią się w pracy magisterskiej, na rzecz której prowadzono badania. Obawa ta wzięła się z faktu, iż romaniści mają wiele do zarzucenia swojemu wydziałowi, a przynajmniej kierunkowi, co wyszło na jaw już na początku prowadzonych badań. Studenci pedagogiki prawie nigdy nie pytali o anonimowość badania i nie sprawiali wrażenia, że cokolwiek ich trapi w związku z udzielaniem wywiadu.

Ze względu na to, że przedmiotem badań miało być ludzkie doświadczenie, jako podejście badawcze wybrano fenomenografię. Termin „fenomenografia” pochodzi z języka greckiego: phainemenon - wygląd oraz graphein - opis. Podejście to jest więc opisem rzeczy dokładnie takich, jakimi je widzimy. Interesującą kwestią według badaczki było sprawdzenie, w jaki sposób studenci będą się wyrażać o tym, czego doświadczają na studiach oraz co w związku z tymi doświadczeniami rozumieją pod pojęciem „studiowania”. Dzięki zastosowaniu podejścia fenomenograficznego autorka miała nadzieję dotknąć zjawisk, które są niedostępne innymi metodami. Techniką zbierania danych był wywiad otwarty pogłębiony, nastawiony na opis konkretnego zjawiska - koncepcji nadawanych studiowaniu w narracjach studentów Uniwersytetu Gdańskiego. Przeprowadzono 20 indywidualnych wywiadów ze studentami. Pytanie podstawowe: Czym jest dla Ciebie studiowanie?, zostało uzupełnione o dodatkowe pytania pomocnicze, jeśli istniała konieczność ich zastosowania (nieśmiałość studenta, obawa przed konsekwencjami, zgubienie wątku). Przyjęta została zasada nasyce-

${ }^{4}$ R.V. Padilla, The unfolding matrix: a technique for qualitative data acquisition and analysis, „Studies in Qualitative Methodology”, nr 4/1994, s. 273-285. 
nia próby, którą Steinar Kvale określa jako punkt nasycenia osiągany w momencie, w którym „dalsze wywiady nie przynoszą nowej wiedzy o przedmiocie” ${ }^{5}$. Rezultatem tychże badań miała być „mapa” odnosząca się do rozumienia zjawiska studiowania.

Podjęte zostały następujące kroki:

a) sporządzono protokoły wszystkich wywiadów, tj. dokonano transkrypcji z dokładnym opisem tego, co miało miejsce podczas prowadzonych badań;

b) bwielokrotnie czytano teksty transkrypcji oraz dokonano kondensacji tekstu polegającej na wyselekcjonowaniu z rozmowy tych fragmentów, które dotyczyły badanego zjawiska;

c) korzystając z publikacji Teoria ugruntowana. Praktyczny przewodnik po analizie jakościowej Kathy Charmaz ${ }^{6}$, dokonano wstępnego kodowania, które miało na celu ułatwienie podjęcia decyzji dotyczących zastosowanej nomenklatury podstawowych kategorii konceptualnych;

d) porównano uzyskane kategorie i skondensowano te, które są takie same, ale ubrane w inne słowa;

e) pogrupowano wypowiedzi na podstawie podobieństw i różnic w obu grupach badanych;

f) znalezione zostało kryterium wyłonienia tychże grup;

g) nazwano kategorię opisu, w taki sposób, by jej nazwa odpowiadała domenie zjawiska.

Po zakończeniu tej części badania dokonano wtórnej analizy uzyskanych danych przy użyciu matrycy Raymonda V. Padilli. Badaczka zdecydowała się zastosować tę metodę, by sprawdzić, czy w którejś z wyznaczonych przezeń kategorii występują braki, i by ewentualnie przeprowadzić dodatkowe wywiady pod tym kątem. Podobnie jak przy kodowaniu w Teorii ugruntowanej pocięto wywiady na części, które następnie podporządkowano różnym koncepcjom studiowania. Na tym etapie można było wstępnie zacząć porównywać różnice i podobieństwa w koncepcjach studiowania studentów romanistyki i pedagogiki oraz częstotliwość występowania danej koncepcji. Na tym zakończył się etap przygotowujący do wyciągnięcia ostatecznych wniosków.

Jak każda metoda badawcza również fenomenografia ma pewne ograniczenia. Przede wszystkim bada kolektywne nadawanie znaczeń, „odrywa” więc wypowiedzi od ich autorów, a co za tym idzie - badacz oscyluje wokół jednego lub kilku fragmentów całego wywiadu. Jako badanie jakościowe w porównaniu z badaniem ilościowym jest ona mało usystematyzowana. W fenomenografii nie stosuje się wnioskowania statystycznego. Nie można więc powiedzieć, że koncepcje, które wyłoniły się w trakcie badania, da się uznać jako reprezentatywne dla wszystkich studentów romanistyki czy pedagogiki.

\footnotetext{
5 S. Kvale, dz. cyt., s. 13-88.

${ }^{6}$ K. Charmaz, Teoria ugruntowana. Praktyczny przewodnik po analizie jakościowej, Wydawnictwo Naukowe PWN, Warszawa 2009.
} 


\section{Wyniki badań - koncepcje nadawane studiowaniu przez studentów pedagogiki}

W wywiadach przeprowadzonych wśród studentów pedagogiki udało się wyłonić osiem wiodących koncepcji studiowania. Pierwszą było studiowanie jako przygotowanie do pracy.

Studiowanie jest dla mnie przede wszystkim przygotowaniem do pełnienia przyszłej pracy. $(01 \mathrm{~K} 25,2016)$

Studiowanie jest dla mnie też zwyczajnie furtką pozwalającą na uzyskanie tytułu i pracę. $(04 \mathrm{~K} 23,2016)$

Studiując resocjalizację, mam nadzieję, iż uda mi się znaleźć pracę w Zakładzie Karnym... (05K23, 2016)

Trzy wymienione wypowiedzi pochodzą z wywiadów, które wyraźnie określają uniwersytet jako centrum kształcenia profesjonalistów - te studentki nie traktują uczelni jako miejsce działalności badawczej. Są głównie zainteresowane uzyskaniem kwalifikacji do pracy, którą pragną wykonywać w przyszłości.

Studiowanie pomaga mi w osiągnięciu celu, pomimo kiepskich okoliczności, jakie mu często towarzyszą. (01K25, 2016)

Jednak takie rozwiązanie nie jest dla mnie odpowiednie, bo zależy mi na wykształceniu i dążeniu do spełniania swoich marzeń związanych z pracą. $(01 \mathrm{~K} 25,2016)$

Studiowanie jest też dla mnie świadomością, że sama kieruję swoim postępem, wyznaczam drogę swojej kariery zawodowej i decyduję, jak może wyglądać moje dalsze życie. $(03 \mathrm{~K} 23,2016)$

W kolejnych trzech wypowiedziach łatwo zauważyć, że studiowanie jest częścią życiowego planu, jest krokiem do spełnienia marzeń i założeń związanych z karierą zawodową. Młodzi ludzie często troszczą się o swoją niezależność finansową i również dlatego decydują się na podjęcie nauki na uczelni wyższej:

Studiowanie dla mnie akurat jest dążeniem do celu, który chcę osiągnąć w przyszłości. (04K23, 2016)

Ogólnie to studia to takie przygotowanie do pracy... no bo jak już masz tego magistra, to trochę jest łatwiej ogarnąć jakąś robotę potem. (09M22, 2017)

Poza tym, liczę, że dostanę później pracę, która będzie dobrze płatna. (10M21, 2017)

Wiadomo, że ludzie studiują po to, żeby znaleźć pracę i w sumie głównie po to jestem na studiach. $(07 \mathrm{~K} 25,2016)$

Bardzo często zdobycie pracy w zawodzie okazuje się być życiowym celem lub marzeniem. Studia na tym kierunku umożliwiają w takim razie realizację pragnień i osiągnięcie satysfakcji: 
[...] zależy mi na wykształceniu i dążeniu do spełniania swoich marzeń związanych z pracą. [...] Studiowanie pomaga mi w osiągnięciu celu, pomimo kiepskich okoliczności, jakie mu często towarzyszą. (01K25, 2016)

Studiowanie jest też dla mnie świadomością, że sama kieruję swoim postępem, wyznaczam drogę swojej kariery zawodowej i decyduję, jak może wyglądać moje dalsze życie. (03K23, 2016)

Studiowanie dla mnie akurat jest dążeniem do celu, który chcę osiągnąć w przyszłości. [...] w moim wypadku jest to doskonalenie się w kierunku, w którym w przyszłości chcę pracować [...]. (04K23, 2016)

Można w takim razie wnioskować, że studenci pedagogiki traktują studia jako pewien etap w życiu, który pozwala zrealizować założony wcześniej cel, jakim jest zdobycie pracy. Wydaje się to być praktyczne podejście do nauki, która w tym przypadku ma na celu przygotowanie ich do kultury zastanej - świata, w którym trudno znaleźć zatrudnienie, a tytuł magistra zdobyty na renomowanej uczelni ma być kluczem do sukcesu.

Kolejną pojawiającą się koncepcją jest studiowanie jako spotkanie z ludźmi inspirującymi i godnymi podziwu. Wykładowcy są chwaleni przez studentów, ci drudzy wspominają o pasji, inteligencji oraz zaszczepianiu w nich chęci samorozwoju:

Często, gdy słucham niektórych wykładowców, czuję podziw wobec nich i chęć rozwoju. $(01 \mathrm{~K} 25,2016)$

Tutaj jest o wiele więcej wykładowców, którzy robią to z pasją, potrafią wytłumaczyć studentowi w sposób zrozumiały to, co chcą przekazać. $(05 K 23,2016)$

Miejsce realizacji „projektu praca” okazuje się też być miejscem, gdzie spotyka się ludzi o ciekawych poglądach i zainteresowaniach, i to oni niejako popychają studentów do samorozwoju.

Studiowanie to dla mnie okres, w którym spotykam całą masę inspirujących ludzi. $(07 \mathrm{~K} 25,2016)$

Studiowanie to codzienne spotkania z pasjonatami, którzy zręcznie zarażają większość z nas swoją pasją. $(07 \mathrm{~K} 25,2016)$

Pojawia się również stwierdzenie, że studiowanie to rozwijanie i odnajdywanie zainteresowań:

Świadomy wybór kierunku studiów może dać człowiekowi możliwość poszerzania horyzontów we wszystkich możliwych kierunkach. $(07 \mathrm{~K} 25,2016)$

W tej chwili studiowanie to dla mnie czas, kiedy świetnie bawię się, nabywając nową wiedzę. Rzadko kiedy wychodzę z uczelni, znając odpowiedź na wszystkie nurtujące mnie pytania, najczęściej jest tak, że pojawia się ich jeszcze więcej i to właśnie one sprawiają, że staram się sama znaleźć na nie odpowiedzi, mam ochotę porozmawiać z wykładowcą, nawet jak skończyły się już zajęcia. (07K25, 2016) 
Poszedłem na studia i nie do końca wiedziałem, czy będę lubił pracę z dziećmi, ale po praktykach i tym jak wykładowcy pokazują nam metody nauczania, wiem na pewno, że to jest właśnie to. Prowadzący są megainspiracją. (09M22, 2017)

Studenci wspominają również o nowych znajomościach, które pojawiły się w ich życiu dzięki studiowaniu. W tym przypadku chodzi o studiowanie jako poznawanie nowych ludzi. Są tu wymieniane znajomości związane z zainteresowaniami oraz wiara w to, że przetrwają długie lata:

Studiowanie pozwala też na poznanie wielu ciekawych ludzi, którzy chcą kroczyć tą samą ścieżką życiową co ja. Nawiązuje się wtedy wiele znajomości, które często trwają bardzo długo. $(01 \mathrm{~K} 25,2016)$

Podczas studiów poznaje się dużo nowych znajomych, zaczyna bywać w klubach, pubach, odkrywać nowe miejsca. $(01 \mathrm{~K} 25,2016)$

Pojawiły się też wypowiedzi, które wskazują na studiowanie jako dojrzewanie:

Oprócz tego, na studiach nie zdobywa się tylko wiedzy, która jest potrzebna w konkretnym celu... zdobywa się wiedzę życiową, np. słuchając elokwentnych wykładowców, którzy bywają swoistą inspiracją. $(01 \mathrm{~K} 25,2016)$

Studia to dla mnie swego rodzaju szkoła życia, ponieważ próba podjęcia jakiś zmian np. zmiany promotora, wiążę się z przejściem pewnej drogi. (02K23, 2016)

Studiowanie uczy tolerancji, organizacji siebie i zarządzania czasem. To piękny okres w życiu młodego człowieka. (07K25, 2016)

W tym przypadku w pewnym sensie sprawdza się rola uniwersytetu jako miejsca, które przygotowuje młodych ludzi do dorosłego życia. Bardzo często przeprowadzają się oni do nowego miasta, gdzie mieszkają sami i sami dbają o siebie. Uniwersytet jako nauczyciel in loco parentis.

Znacznie rzadziej studenci pedagogiki wspominają o szkole, gdy mówią o studiowaniu - określają studiowanie jako inną formę nauki niż w szkole:

Studiowanie jest dla mnie wyższym poziomem procesu uczenia się. Studiowanie według mnie to zgłębianie, doświadczanie, zaspokajanie ciekawości. Uważam, że efektywne studiowanie wymaga dużo własnej pracy. $(03 K 23,2016)$

Studiowanie to dla mnie taki okres przejściowy między dzieciństwem a dorosłością. Studiowanie to nie szkoła, w której ktoś kontroluje, co i kiedy robimy, można nie być systematycznym i radzić sobie lepiej niż ci, którzy gorliwie wykonują swoje obowiązki. (08K24, 2016)

Kolejny raz potwierdza się teza, że uniwersytet nie tylko kształci nas intelektualnie, ale również wpływa na nasz rozwój psychiczny, na naszą dojrzałość oraz świadomość samych siebie. Innymi słowy, kształtuje naszą tożsamość.

Studiowanie jako swoboda oraz studiowanie jako stres to dwie koncepcje, które również pojawiły się w wywiadach. Ta pierwsza mówi o mnogości wyborów, jakich 
dokonujemy podczas studiów - zajęcia fakultatywne czy lektury. Stres natomiast dotyczy okresu wokół sesji egzaminacyjnej.

\section{Wyniki badań - koncepcje nadawane studiowaniu przez studentów romanistyki}

Wśród studentów romanistyki powtarzającą się koncepcją studiowania jest studiowanie jako dojrzewanie:

To wszystko kształtuje nasz ogląd na ludzi i uczy nas, jak radzić sobie w różnych sytuacjach. (R1K28, 2016)

Ogólnie, studiowanie wspominam jako proces, a jego początek jako pewną datę graniczną - z ucznia stałam się studentem i niejako wkroczyłam w dorosłość. Studia to okres pełnej odpowiedzialności za swoje działania i zaniechania. (R2K24, 2016)

Nauczenie się tej sztuki zajęło mi sporo czasu, ale ukształtowało mnie prawdopodobnie do końca mojego życia. Teraz nie mam problemu z filtrowaniem informacji, którymi jesteśmy dziś bombardowani ze wszystkich stron - telewizja, radio, Internet, gazety - i jak tu odnaleźć ważne informacje? Mnie nauczyły tego właśnie studia. Ta otwartość umysłu, umiejętność analizowania i syntetyzowania informacji to cechy bardzo pożądane na rynku pracy, ale myślę, że to jest rzecz drugorzędna. (R3K27, 2016)

Podobnie jak studenci pedagogiki, ci z romanistyki również wspominają o dojrzewaniu oraz o wpływie studiów na swoją tożsamość.

Dlatego ludziom, którzy uważają, że studia nie przystosowują do życia i rynku pracy i są latami straconymi dyskutowania o rzeczach irrelewantnych, mówię zawsze, że studia przygotowują do życia, chociaż nie w sposób oczywisty, dając umiejętności praktyczne, ale w wymiarze dużo głębszym, zmieniając cały nasz sposób myślenia. (R3K27, 2016)

Musiałam nauczyć się zarządzać własnymi finansami. To też jest lekcja na całe życie, gdyby nie studia, byłoby mi o wiele trudniej w tak zwanym „dorosłym życiu". Tak, bo studia to taki egzamin zerowy, używając terminologii akademickiej. (R4K22, 2016)

Nauczyłam się, że moja opinia nie zawsze jest słuszna, że w dyskusji najważniejsza jest tolerancja i słuchanie tego, co mówią inni. (R4K22, 2016)

Co istotne, studenci nie wspominają jedynie o aspektach dotyczących utrzymania się czy zarządzania czasem jako tych związanych z dorosłością, ale wymieniają też inne zdobywane kompetencje dotyczące nawiązywania kontaktów czy dojrzewania emocjonalnego. 
Ukształtowałam swój światopogląd i z nieśmiałej dziewczyny stałam się pewną siebie młodą kobietą. (R3K27, 2016)

Czas studiowania to też moment, w którym stajemy się dorośli i oczekujemy, że nie będziemy traktowani jak uczniowie w gimnazjum, którzy nie wiedzą, co dla nich dobre, więc nauczyciel jest guru i im mówi, co dokładnie robić i czytać. (R6K28, 2016)

Studiowanie to dla mnie czas przygotowania do życia dorosłego. Trzeba sobie było poradzić z ogarnięciem budżetu, praniem, sprzątaniem, gotowaniem i ogólnym zarządzeniem czasu tak, aby starczyło go na wszystko. (R9K22, 2016)

Studia przygotowują do dorosłego życia - spotykamy na swojej drodze nie tylko wyzwania, z którymi trudno sobie poradzić, ale i nieprzychylnych nam ludzi - trening, jaki przechodzą studenci w trakcie studiów, może okazać się niezwykle przydatny po opuszczeniu murów uczelni.

Wśród romanistów pojawia się koncepcja, która mówi o tym, że studiowanie to poniżanie:

Generalnie wykładowcy nie traktują nas zbyt poważnie, mówią nam po imieniu, jak coś źle powiemy, to nas wyśmiewają przy całej grupie. Jedna babeczka powiedziała nam, że nas nauczy pisać CV, żebyśmy mogli złożyć do McDonald'sa, bo się nie nadajemy do niczego innego. (R6K28, 2016)

Na porządku dziennym było poniżanie nas i pokazywanie nam, że wykładowca to Bóg i powinniśmy całować ślady jego butów, jak przechodzi holem. Studiowanie było dla mnie udręką, spotykaniem wykształconych ludzi z niską kulturą osobistą, no i poznawaniem nowych ludzi. (R5K25, 2016)

Poniżej kolejne cytaty, które wskazują na to, że wykładowcom zdarza się podkreślać swoją wyższość ze względu na obejmowane stanowisko. Studenci boją się zabrać głos w dyskusji, a zwłaszcza gdy nie są pewni, czy to, co powiedzą, będzie zgodne z poglądami wykładowcy:

Nie chcę siać plotek, no ale oni są po prostu nieprzyjemni, a zajęcia są po prostu nudne. Materiały dla nas też się wydają być przez wiele lat niezmieniane. Ostatnio na zajęciach powiedziałam swoje zdanie na jakiś tam temat, to tylko wywołałam oburzenie, że co ja sobie wyobrażam i myślę, że mam siedzieć cicho i słuchać. (R4K22, 2016)

U nas studiowanie to też obawa przed byciem wystawionym na pośmiewisko, bo jak popełnimy błąd, to on jest nam wytykany przed całą grupą. Taki to trochę brak szacunku do nas. (R8K24, 2016)

W pewnym sensie te studia to nasza walka o przetrwanie. (R8K24, 2016)

Studia to ciężka praca, studia to brak szacunku od wykładowców... (R9K22, 2016)

Studiowanie na wydziale filologicznym było dla mnie udręką. Każdego dnia czułam się zestresowana, spięta, a myśl o spędzeniu kolejnego dnia w murach 
wydziału przyprawiała mnie o mdłości. Idąc na studia inaczej wyobrażałam sobie rzeczywistość uniwersytecką. Niestety realia szybko wyprowadziły mnie $\mathrm{z}$ błędu. Studiowanie okazało się być mordęgą. Wszystkie zajęcia odbywały się w ten sam sposób - wykładowca równy Bogu i wszystko w jego rękach, oczywiście sprawdzanie obecności, a następnie wytykanie opuszczonych zajęć i oczekiwanie wytłumaczenia na porządku dziennym - „sprawy rodzinne? Jakie?”. (R10K26, 2016)

Studiowanie było dla mnie czekaniem na łaskę wykładowcy, kajaniem się i ciągłym stresem. (R1K28, 2016)

\section{Romaniści niejednokrotnie porównują studiowanie do szkoły:}

Studia na wydziale filologicznym były dla mnie czymś w rodzaju powrotu do liceum. Powodem tych rozbieżności w moich odczuciach były: liczebność studentów roku i grup ćwiczeniowych, podejście wykładowców, sposób prowadzenia zajęć, formy sprawdzania wiedzy, a nawet aranżacja wnętrz i praca administracji. (R6K28, 2016)

Obecność była skrupulatnie sprawdzana, na głos - i właśnie to i aranżacja wnętrza już podczas pierwszych zajęć przywołało mi na myśl naukę w szkole. Wykładowcy zwracający się często do studentów „po imieniu” jak do uczniów. Obowiązkowa obecność na zajęciach, dyktowanie notatek oraz uczenie się nie kompleksowe, ale w celu zaliczenia sprawdzianu z konkretnej partii materiału. Brak elastyczności i nastawienie, że studenci L1 to w zasadzie nastolatki, brak przystosowań do starszych studentów, dla których były to kolejne studia bądź pracowali oprócz tego zawodowo. (R6K28, 2016)

Można podejrzewać, że na romanistyce realizowany jest świadomie lub nie ukryty program - zwłaszcza jeśli weźmiemy pod uwagę aranżację wnętrz lub zapytamy starszych studentów - tych, którzy studiowali w dzielnicy Strzyża.

Bo u mnie na kierunku są normalnie sprawdziany, prawie takie same jak miałam kiedyś na francuskim w ogólniaku. No i są też kartkówki, które oczywiście trzeba poprawiać, jak się nie zda albo źle napisze. Generalnie wykładowcy nie traktują nas zbyt poważnie, mówią nam po imieniu, jak coś źle powiemy, to nas wyśmiewają przy całej grupie. (R6K28, 2016)

Tutaj to jest jednak kontynuacja tradycyjnej nauki szkolnej, a nie jakieś takie studiowanie, jak się widzi w filmach - czytanie książek i szperanie w bibliotece. Tutaj musisz umieć konkret, bez żadnych refleksji, bo one mogą spowodować dyskwalifikację. Jak piszesz pracę, to masz powielać schematy, bo możesz napisać pracę w dobrej formie, ale wypowiedzieć się kontrowersyjnie, to wtedy też raczej nie zdasz. (R8K24, 2016)

Takie podejście - unikanie refleksji czy dyskusji - sprawia, że niemożliwe jest prowadzenie sensownej działalności badawczej.

Wszystkie zajęcia odbywały się w ten sam sposób - wykładowca równy Bogu i wszystko w jego rękach, oczywiście sprawdzanie obecności, a następnie wy- 
tykanie opuszczonych zajęć i oczekiwanie wytłumaczenia na porządku dziennym - „sprawy rodzinne? Jakie?”. (R10K26, 2016)

Studiowanie tutaj to taka trochę szkoła, ale na pewno nie miejsce z inspirującymi ludźmi... (R2K24, 2016)

Z wypowiedzi studentów wynika, że studia były dla nich trudne do zniesienia wyczerpujące psychicznie.

Kolejną koncepcją, która wyłoniła się w wywiadach, jest studiowanie jako przygotowanie do pracy:

Należy także podkreślić znaczenie głównego celu studiowania, czyli podjęcia w przyszłości pracy związanej z obranym kierunkiem. (R10K26, 2016)

Studiowanie dla mnie to przede wszystkim przygotowanie do przyszłego życia zawodowego. (R3K27, 2016)

Studiowanie jest dla mnie sposobem na zapewnienie sobie dobrej przyszłości. Liczę, że jak będę miała magisterkę, to szybko dostanę pracę, zwłaszcza, że francuski się robi teraz popularny. (R4K22, 2016)

Studiowanie to również forma utorowania sobie ścieżki życiowej, trzeba się dużo uczyć, zostać specjalistą w swojej dziedzinie i móc tym zarabiać na życie. (R7K24, 2016)

Gdybym miała podsumować, to studiowanie jest dla mnie po prostu drogą do zdobycia pracy. $(08 \mathrm{~K} 24,2016)$

Jedną z kolejnych koncepcji studiowania na Wydziale Neofilologicznym jest stu-

\section{diowanie jako poznawanie nowych ludzi:}

W okresie studiowania napotykamy również przeróżne osobowości na swojej drodze, tworzą się trwałe przyjaźnie, takie na chwilę, lub nawet relacje konfliktowe i nieprzyjemne. (R1K28, 2016)

Okres studiowania już za mną i czasem myślę o tym ze smutkiem, bo nie mam już tylu okazji do spotkań towarzyskich... (R3K27, 2016)

Poznałam wielu ludzi, z wielu różnych regionów Polski. (R2K24, 2016)

Następną koncepcją, która została wyszczególniona w trakcie badania, jest studiowanie jako czekanie:

Innym zagadnieniem, które warto poruszyć, jest punktualność. Każdy bowiem ma prawo do spóźnień. Jednakże brakiem szacunku wobec grupy swoich uczniów może być sytuacja, gdy na egzaminy wykładowca nie zjawia się wcale. (R8K24, 2016)

Studiowanie jest też dla mnie koczowaniem pod gabinetem wykładowcy i liczeniem, że może dzisiaj mnie wpuści na konsultacje, bo obiad zjadł wcześniej. Zdarzyło mi się być dwie godziny w czasie konsultacji i się na nie nie dostać, bo pani jadła obiad albo gadała przez telefon. No a takie sytuacje, że się nie dosta- 
łam, bo jest milion osób, które coś poprawiają, to są na porządku dziennym, bo u nas nikt niczego nie zdaje za pierwszym razem. (R5K25, 2016)

Wieczne czekanie pod gabinetami w trakcie konsultacji, bo wykładowca je obiad, przyszła żona lub akurat rozmawia przez telefon z koleżanką - czas minął? Ups, proszę przyjść jutro. Masz pytanie? Od tego jest biblioteka. (R7K24, 2016)

Trudno powiedzieć, o czym świadczy brak czasu wykładowców w trakcie konsultacji, być może nikt nie kontroluje tego, co robią w tym czasie.

Studiowanie to również niekończące się czekanie na spóźniającego się wykładowcę, na konsultacje i na wyniki zaliczeń. Trudno było się uczyć na błędach, skoro kolejne zaliczenia następowały bez feedbacku z poprzednich. (R3K27, 2016)

Dla mnie studiowanie okazało się być nauką cierpliwości i oczekiwania. Wszyscy mówią, że panie w dziekanacie są powolne i na wszystko trzeba czekać, na moim wydziale to chyba jedyne miejsce, w którym wszystko działa sprawnie. A reszta działa jak chce. Student musi przestrzegać zasad, wykładowca może wszystko. (R2K24, 2016)

Romaniści wspominają również o studiowaniu jako odkrywaniu i rozwijaniu zainteresowań:

Jest to etap, w którym odkrywamy, co nas naprawdę interesuje, odkrywamy również rzeczy, które nie interesują nas wcale. (R5K25, 2016)

Są wśród nich zajęcia pasjonujące ( $w$ moim przypadku jako absolwentki romanistyki były to przede wszystkim zajęcia praktycznie z języka francuskiego, zajęcia dotyczące kultury krajów francuskojęzycznych oraz przedmioty związane z pedagogiką). (R3K27, 2016)

\section{Porównanie koncepcji studiowania na obu kierunkach}

W wywiadach na obu badanych kierunkach część koncepcji nadawanych studiowaniu jest taka sama, jednak występują one w innych proporcjach. Pierwsze podejście, które wyłoniło się wśród studentów pedagogiki, czyli studiowanie jako przygotowanie do pracy, pojawia się również $\mathrm{w}$ wywiadach ze studentami romanistyki, ale nie jest ono w ich przypadku pierwszą, podstawową koncepcją nadawaną studiowaniu. Romaniści wspominają o niej dopiero na czwartym miejscu.

Studiowanie jako spotkanie z ludźmi inspirującymi i godnymi podziwu druga koncepcja studiowania pedagogów nie pojawia się w ogóle wśród romanistów. Tu należy zadać sobie pytanie, dlaczego tak się dzieje? Być może odpowiedzą mogą być dwie koncepcje, które wyłonione zostały w wywiadach z romanistami, a o których pedagodzy nie wspominają, tj.: studiowanie to poniżanie oraz studiowanie jako czekanie. Te dwa podejścia mogą wskazywać na problemy, z jakimi borykają się studenci romanistyki, a o których istnieniu nie mówią ci z pedagogiki. 
Obie grupy badanych wspominają o tym, że studiowanie jawi im się jako rozwijanie i odnajdywanie zainteresowań, choć ta koncepcja pojawia się rzadziej wśród filologów, to jest obecna i pozwala sądzić, że ludzie, którzy trafili na te kierunki studiów, dokonali dobrego wyboru.

Studiowanie jest dla studentów obu omawianych kierunków również poznawaniem nowych ludzi; zarówno jedni, jak i drudzy mówią o nawiązywaniu przyjaźni.

Będące na czele koncepcji nadawanych studiowaniu wśród studentów romanistyki - studiowanie jako dojrzewanie - pojawia się u studentów pedagogiki dopiero na czwartym miejscu. Badani opisują rozłąkę z rodzicami i mieszkanie w nowym mieście jako okazję do nauczenia się zarządzania finansami i czasem, a także jako formę nabywania inteligencji emocjonalnej - sami muszą radzić sobie ze stresem i przeciwnościami losu.

Kolejna koncepcja wyłoniona w wywiadach ze studentami pedagogiki - studiowanie jako inna forma nauki niż w szkole - nie pojawia się w wypowiedziach romanistów, oni mówią o studiowaniu jako szkole. Z ich doświadczeń dotyczących studiowania wynika, że studia jako forma nauki nie różnią się od tej, jaką znają ze szkół średnich czy techników. Gdyby mówić o kierunkach technicznych, łatwiej wyobrazić sobie podobieństwa, jednak studia na kierunkach humanistycznych z założenia mają mieć inną formę niż nauka w szkole.

Dwie ostatnie koncepcje, które wyłonione zostały w wywiadach ze studentami pedagogiki, czyli studiowanie jako swoboda oraz studiowanie jako stres, nie pojawiają się w wywiadach ze studentami romanistyki, choć w wypowiedziach mówiących o tym, że studiowanie wiąże się dla nich z poniżaniem, można doszukiwać się informacji o stresie, który towarzyszy nauce. Emocje te jednak dotyczą obawy przed wystawieniem na pośmiewisko - inaczej niż w przypadku studentów pedagogiki, którzy przywołują tę koncepcję, gdy myślą o sesji egzaminacyjnej czy ważnych zaliczeniach.

\section{Zakończenie}

Z przeprowadzonych badań wynika jednoznacznie, że mimo iż oba kierunki należą do nauk humanistycznych, a nawet zawierają specjalizację nauczycielską, to ich jakość i forma kształcenia są wyraźnie różne. Rezultaty badań są niepokojące. Celem tych badań nie było skrytykowanie „od stóp do głów” Wydziału Neofilologicznego, ale próba porównania koncepcji studiowania studentów z dwóch kierunków na jednej uczelni. Intencją autorki było również wskazanie, jakie elementy studiowania mają wpływ na funkcjonowanie studenta oraz jakie cechy przypisuje on studiowaniu ze względu na to, w jakiej rzeczywistości się znajduje. 


\section{Bibliografia}

Bauman T., Poznawczy status danych jakościowych, [w:] J. Piekarski, D. Urbaniak-Zając, K.J. Szmidt (red.), Metodologiczne problemy tworzenia wiedzy w pedagogice. Oblicza akademickiej praktyki, Oficyna Wydawnicza Impuls, Kraków 2010.

Bauman T., Uniwersytet wobec zmian społeczno-kulturowych: casus Uniwersytetu Gdańskiego, Wydawnictwo Uniwersytetu Gdańskiego, Gdańsk 2001.

Czerepaniak-Walczak M., Fabryki dyplomów czy universitas?: o nadwiślańskiej wersji przemian w edukacji akademickiej, Oficyna Wydawnicza Impuls, Kraków 2013.

Kozyr-Kowalski S., Uniwersytet a rynek, Wydawnictwo Naukowe UAM, Poznań 2005. Krzychała S., Zamorska B., Dokumentarna ewaluacja szkolnej codzienności, Wydawnictwo Naukowe Dolnośląskiej Szkoły Wyższej, Wrocław 2008.

Kvale S., Interviews. Wprowadzenie do jakościowego wywiadu badawczego, Trans $\mathrm{Hu}-$ mana, Białystok 2004.

Malewski M., Metody ilościowe i jakościowe w badaniach nad edukacją. Spór o metodologiczna komplementarność, „Kultura i Edukacja”, nr 1-2/1997.

Newman J., General Knowledge viewed as One Philosophy, [w:] tegoż, Discourses on the Scope and Nature of University Education: Addressed to the Catholics of Dublin, Cambridge University Press, Cambridge 2010.

Padilla R.V., The unfolding matrix: a technique for qualitative data acquisition and analysis, „Studies in Qualitative Methodology”, nr 4/1994.

Rutkowiak J., Uczenie się jako problem etyczny. O zewnętrznym $i$ wewnętrznym uczeniu się, [w:] T. Bauman (red.), Uczenie się jako przedsięwzięcie na całe życie, Oficyna Wydawnicza Impuls, Kraków 2005.

Uniwersytet zaangażowany. Przewodnik krytyki politycznej, oprac. zbiorowe, Wydawnictwo Krytyki Politycznej, Warszawa 2010.

\section{One University and two worlds - comparative analysis of studying concepts}

Abstract: The article presents concepts of studying of students of Pedagogy and of Romance Studies at the University of Gdansk. Phenomenological studies based on semi-structured interviews were carried out. Despite the similarity of the faculties, differences in concepts have emerged. In addition to expected concepts such as studying as preparation for work, some surprising concepts were revealed: studying as humiliation or studying as waiting. The author of the text is a graduate of both studied faculties.

Keywords: studying, concepts of studying, Gdansk University, pedagogy, Romance studies

About the author: Paulina Białka - PhD student at the Institute of Pedagogy at the University of Gdansk, research interests: quality of education, university cultures, contemporary university. 


\title{
Obraz i wsparcie dziecka nieśmiałego w percepcji nauczycieli edukacji przedszkolnej
}

DOI: 10.25312/2083-2923.15/2019_12mm

\begin{abstract}
Streszczenie: W niniejszym artykule dokonano analizy obrazu dziecka nieśmiałego w wieku przedszkolnym i zakresu udzielanej mu pomocy ze strony nauczyciela edukacji przedszkolnej. Opisano, z jakimi trudnościami zmaga się dziecko nieśmiałe w wieku przedszkolnym, i na tej podstawie wskazano proponowane oddziaływania pedagogiczne wobec dziecka nieśmiałego w wieku przedszkolnym ze strony nauczyciela.
\end{abstract}

Słowa kluczowe: nieśmiałość, dziecko nieśmiałe, dziecko w wieku przedszkolnym, nauczyciel edukacji przedszkolnej

\section{Wprowadzenie}

Pedagog/wychowawca grupy przedszkolnej, obserwując swoich podopiecznych, może dostrzec indywidualność, a także różnorodność ich zachowań. Każde dziecko jako osoba jest wyjątkowe - swoją osobowością i obecnością wzbogaca drugiego człowieka, $\mathrm{z}$ którym przebywa, $\mathrm{w}$ tym przypadku swoich kolegów i koleżanki z grupy oraz wychowawców. Prawie w każdej grupie są dzieci pewne siebie, przebojowe, żywiołowe, ale także te ciche, spokojne i wstydliwe. O tych drugich mówimy, że są nieśmiałe. Są to dzieci, które mają problem z sygnalizowaniem swoich potrzeb, które nie mówią głośno o tym, co w danym momencie chciałyby otrzymać, i nie mają siły i predyspozycji osobowościowych, aby przykuć uwagę nauczyciela i „przebić się” przez grupę rówieśników. Celem niniejszego opracowania jest poznanie obrazu dziecka nieśmia-

* Małgorzata Mróz - magister pedagogiki, absolwentka Wydziału Nauk Pedagogicznych Uniwersytetu Kardynała Stefana Wyszyńskiego w Warszawie. Zainteresowania naukowe: pedagogika przedszkolna i wczesnoszkolna, nieśmiałość dziecka, edukacja włączająca uczniów ze specjalnymi potrzebami edukacyjnymi. 
łego z perspektywy nauczyciela edukacji przedszkolnej oraz zgromadzenie informacji na temat zakresu udzielanego mu wsparcia ze strony pedagoga/wychowawcy. Wsparcia, ponieważ nieśmiałość może być źródłem cierpień i niepowodzeń dla dziecka oraz negatywnie wpływać na jego dalsze funkcjonowanie w przyszłości jako osoby dorosłej. Celem szczegółowym uczyniono poznanie trudności, z jakimi zmaga się dziecko nieśmiałe w wieku przedszkolnym, i na tej podstawie wskazanie możliwych oddziaływań pedagogicznych ze strony nauczyciela edukacji przedszkolnej.

Postawione cele pozwoliły na sformułowanie następujących problemów badawczych:

- Jakimi cechami osobowości, zdaniem nauczycieli, charakteryzuje się dziecko nieśmiałe $\mathrm{w}$ wieku przedszkolnym?

- Jakie zachowania, zdaniem nauczycieli, przejawia dziecko nieśmiałe w grupie przedszkolnej?

- Jak bardzo złożony jest problem nieśmiałości dziecka w wieku przedszkolnym w opiniach nauczycieli?

- Jaki jest zakres udzielanego wsparcia dziecku nieśmiałemu w wieku przedszkolnym ze strony nauczycieli?

Dzieci nieśmiałe są często niedostrzegane przez otoczenie, wynika to z tego, że są grzeczne, nie sprawiają kłopotów wychowawczych i nie zadają podchwytliwych pytań $^{1}$. Problem dzieci nieśmiałych jest zazwyczaj traktowany marginalnie jako zjawisko, które wprawdzie istnieje, ale nikomu nie szkodzi². W centrum zainteresowania nauczyciela/wychowawcy są dzieci śmiałe i energiczne, tzn. te, które nie mają oporów przed mówieniem na forum klasy o swoich przeżyciach, emocjach, uczuciach. Te dzieci często jako pierwsze biorą udział w różnych inicjatywach i przedsięwzięciach, a dzieci nieśmiałe są na tzw. szarym końcu. Są jakby niewidoczne i niezauważalne. Z powodu braku odwagi zaprezentowania swojej wiedzy przed rówieśnikami i nauczycielem w klasie mogą być też niedoceniane. Niekiedy nauczyciele gorzej je oceniają. Dowodem na to stwierdzenie jest konstatacja Ireny Dzwonkowskiej, która pisze, że nauczyciele niżej oceniają dzieci nieśmiałe na wielu polach, np. głośnego czytania, ustnych odpowiedzi w klasie. „Nauczyciele uważają, że ci uczniowie, którzy są zahamowani w nowych sytuacjach, mają niższy poziom inteligencji mierzony ilorazem inteligencji niż uczniowie chętnie angażujący się w nowe sytuacje. W rzeczywistości obie grupy dzieci nie różnią się wynikami mierzonej inteligencji”’3. Dzieci nieśmiałe mają wiele pozytywnych cech - nie przejawiają agresji, są dobrymi słuchaczami, obserwatorami, a także serdecznymi przyjaciółmi. Ich głównym problemem jest to, że czują się skrępowane i niepewne, przebywając w różnych grupach społecz-

${ }^{1}$ M. Goetz, Cicha myszka w klasie, „Głos Nauczycielski”, nr 4/2014, s. 14.

2 D. Gulińska-Grzeluszka, Metody pracy $z$ dzieckiem nieśmiałym $w$ szkole, [w:] E. Przygońska (red.), Praca $z$ dzieckiem wymagajacym, Wydawnictwo Adam Marszałek, Toruń 2011, s. 157.

${ }^{3}$ I. Dzwonkowska, Nieśmiałość a wspierające i trudne relacje z ludźmi, Oficyna Wydawnicza Impuls, Kraków 2009, s. 86. 
nych, tj. w przedszkolu, szkole, na podwórku. Ta nieśmiałość może być czymś uciążliwym i utrudniać funkcjonowanie dziecka.

Nieśmiałość jest cechą, która swoje pejoratywne znaczenie zawdzięcza po części współczesnej kulturze. Wydaje się, że społeczeństwo wymaga od nas bezpośredniej komunikacji i śmiałości. Dzieci nieśmiałe nie posiadają tych zdolności. W dzisiejszych czasach „cechy charakteru, które cieszą się społecznym poważaniem, to zdolności przywódcze, asertywność, dominacja, charyzma, niezależność i odwaga”" Z tego powodu nieśmiałość może być uważana jako coś negatywnego, niepożądanego, pejoratywnego. Warto podkreślić, że nieśmiałość nie jest wadą czy słabością, ale jest wyjątkowym darem, który często cechuje twórczą i obdarzoną wyobraźnią osobowość 5 . W związku z tym ważne jest zwrócenie uwagi pedagogów/wychowawców na dzieci nieśmiałe. Konieczna jest pomoc, aby mogły „nabyć umiejętności, które umożliwią im swobodne zachowanie w nowych okolicznościach, w jakich się znajdą "', oraz potrafiły zaprezentować swoje zalety, talenty, możliwości, które często skrywane są w ich wnętrzu.

\section{Nieśmiałość - definicja pojęcia}

W literaturze przedmiotu można znaleźć różne definicje nieśmiałości. W pierwszym rzędzie jest ona określana jako złożona cecha osobowości, która stanowi część człowieczeństwa. Nie jest zaburzeniem osobowości, chorobą ani wadą charakteru. Najogólniejsza definicja rozumie nieśmiałość jako „cechę osobowości przejawiającą się w obniżeniu poziomu działania w obecności innych ludzi, związanego z nieadekwatną antycypacją negatywnej oceny społecznej, która wywołuje lęk oraz nieuzasadnione uczucie wstydu"7. Nieśmiałość określana jest również jako aktualny stan jednostki, który charakteryzuje się zahamowaniem behawioralnym w konkretnej sytuacji, a także jako względnie trwała i stabilna w czasie cecha osobowości, tzw. nieśmiałość dyspozycyjna ${ }^{8}$.

Warto się dowiedzieć, jak współcześnie podchodzi się do tematu nieśmiałości. Zdaniem Małgorzaty Zabłockiej, jest to „złożony syndrom psychologiczny, obejmujący cały zespół charakterystycznych objawów”. Objawy te widoczne są w zachowaniu, emocjach i ocenieniu siebie przez jednostkę nieśmiałą. Charakterystyczne dla nieśmiałości są zatem zakłócenia w obrębie sfery behawioralnej, emocjonalnej i samo-

${ }^{4}$ B. Carducci, Nieśmiałość. Nowe odważne podejście, Wydawnictwo Znak, Kraków 2008, s. 22.

5 J.S. Jackson, Uwaga! Ważna zasada: „Nieśmiałość to nie wada!”, Wydawnictwo Święty Paweł, Częstochowa 2008, s. 1.

6 Tamże, s. 2.

7 J. Siuta, Słownik psychologii, Wydawnictwo Zielona Sowa, Kraków 2015, s. 166.

${ }^{8}$ I. Dzwonkowska, dz. cyt., s. 17.

9 M. Zabłocka, Zrozumieć nieśmiałość. Aspekty diagnostyczne i terapeutyczne, Wydawnictwo Kazimierza Wielkiego, Bydgoszcz 2012, s. 15. 
orientacyjnej ${ }^{10}$. Zakłócenia w sferze behawioralnej to zaprzestanie działania jednostki w sytuacji przebywania na forum, wśród innych osób i w perspektywie oceny społecznej. Jest to także powstrzymanie się od działania, czyli bierność, a także wycofanie się z kontaktów interpersonalnych. Zaburzenia zachowania jednostki są zauważalne dla całej społeczności. Przejawiają się w obniżeniu i dezorganizacji funkcjonowania jednostki, np. w trudnościach w wypowiadaniu się przed publicznością, niemożności skupienia się na wykonywanych czynnościach w obecności innych. To także małomówność i cichy sposób mówienia. Charakterystycznym symptomem nieśmiałości jest unikanie kontaktu wzrokowego oraz objawy fizjologiczne, tj. czerwienie się, drżenie rąk. Zakłócenia dotyczą też emocji odczuwanych przez jednostkę nieśmiałą. Jest to doświadczenie lęku, napięcia, zdenerwowania, które pojawiają się w sytuacjach, kiedy jednostka znajduje się w centrum zainteresowania innych ludzi i skupia na sobie ich uwagę. Ten pojawiający się lęk utrudnia zebranie myśli, uniemożliwia koncentrację. W sytuacjach społecznej ekspozycji istnieje prawdopodobieństwo wystawienia się na oceny innych ludzi. Osoby nieśmiałe bardzo dużą wagę przywiązują do tego, jak postrzega je społeczeństwo. Towarzyszy temu również uczucie strachu przed kontaktami $\mathrm{z}$ innymi osobami ${ }^{11}$. Aspekt samoorientacyjny obejmuje to, co dana jednostka myśli o sobie, jej stosunek do siebie. Przeważnie jest to poczucie niższości, brak wiary w siebie i swoje możliwości. Jednostka nie docenia siebie lub ma niską samoocenę. Osobom nieśmiałym nieustannie „towarzyszy obawa przed kompromitacją, krytyką, wyśmianiem, doznaniem porażki i przykrości”12.

\section{Charakterystyka dziecka nieśmiałego}

Wśród cech charakteryzujących dziecko nieśmiałe wymienia się: lękliwość, cichość, małomówność oraz zahamowanie w sytuacjach społecznych przede wszystkim nowych i przed nieznajomymi osobami. Irena Dzwonkowska podaje wyniki eksploracji, które dotyczyły czterolatków w sytuacji stresu. Wykazały one różnice w reakcjach wegetatywnych pomiędzy dziećmi śmiałymi i nieśmiałymi. Te drugie miały wyższy wskaźnik uderzeń serca ${ }^{13}$. Dzieciom nieśmiałym z trudnością przychodzi zabieranie głosu w obecności swoich rówieśników i nauczyciela, tj. mają problem ze zwróceniem się do dorosłego o pomoc, nie zgłaszają się przez podniesienie ręki, nawet jeśli znają odpowiedź na zadane pytanie. Na tle innych dzieci rzadko można usłyszeć ich głos. Przeważnie mówią cicho, niepewnie. Są mało aktywne. Nie mają odwagi zaproponować coś od siebie, np. zainicjować zabawę. Dzieci te nie sprawiają

10 Tamże.

11 Tamże.

12 M. Zabłocka, Przezwyciężanie nieśmiałości u dzieci, Wydawnictwo Naukowe Scholar, Warszawa 2008, s. 14.

13 I. Dzwonkowska, dz. cyt., s. 81. 
kłopotów wychowawczych i rzadko wchodzą w konflikty. Jeśli już zdarzy się sytuacja konfliktowa, to trudno im bronić swoich racji, wypowiedzieć swoje zdanie. Są mało asertywne. Wszystko przyjmują ze spokojem i posłuszeństwem. Są uczynne. To, co im sprawia trudność, to nawiązywanie kontaktów z rówieśnikami, rozpoczynanie relacji z kolegą/koleżanką. Przyglądają się zabawie innych dzieci lub bawią się samotnie. Nie wynika to z braku chęci do zabawy z rówieśnikami. Dzwonkowska, przytaczając badania Galiguzowej, pisze, że dzieci nieśmiałe pragną przebywać z innymi dziećmi, ale nie artykułują swoich potrzeb.

Zachowanie dziecka nieśmiałego w wieku przedszkolnym podczas swobodnej zabawy opisuje Jens Asendorph, który obserwował dzieci podczas zabawy w ich naturalnym środowisku: „Gdy jest samotne, jest nieszczęśliwe, ale równocześnie nie chce przeszkadzać innym w zabawie. Stoi gdzieś z boku i czeka, obserwując bawiące się dzieci. Czuje się zestresowane, ponieważ chciałoby podejść i włączyć się w zabawę, ale nie potrafi obrać jakiejkolwiek strategii. A więc stoi i biernie obserwuje, mając nadzieję, że inni zauważą je i zaproszą do zabawy”14. „Nieśmiałe dzieci mają ochotę bawić się z innymi, ale boją się podjąć ryzyko niezbędne przy poznawaniu nowych ludzi. Dzieci, które stoją i czekają, są zwykle psychicznie »młodsze« od swoich rówieśników”15. Do wspólnych zabaw z rówieśnikami dołączają się wtedy, kiedy zostaną zachęcone przez nauczyciela, np. w trakcie zajęć ruchowych przy muzyce. „Nie są jednak pewne, jak się zachować w czasie gry lub zabawy. Są przy tym nadmiernie ustępliwe na każde wezwanie przedsiębiorczych kolegów usuwają się ze swojego miejsca" ${ }^{16}$. Dziecko nieśmiałe, myśląc, że jest obserwowane, jeżeli zauważy, że ktoś na nie patrzy, może przerwać swoją dotychczasową czynność. Można zauważyć, że dzieci te nie mają cech przywódczych, nie są „duszą towarzystwa”. Łatwo podporządkowują się drugiej osobie, zgadzając się na propozycje przez nią podane. Mogą czuć się zdominowane przez innych. Nie lubią hałasu, wolą ciszę i spokój. Przeszkadza im chaos, nieporządek. Badane przez wspomnianego już Asendorpha matki stwierdziły, że ich dzieci „nie lubią głośnego dźwięku szkolnego dzwonka i wolą się bawić z mało hałaśliwymi dziećmi”"17. Ponadto „długo potrafią bawić się tą samą zabawką. Nie lubią zmian szeregu rutynowych zachowań, a także nowych pokarmów, nowego miejsca przy stole, nowych ubrań, zmiany ustalonej kolejności ubierania się. Negatywnie reagują na sytuacje, które są źródłem radości dla innych dzieci np. nie czują się dobrze na swoich przyjęciach urodzinowych"18. W badaniach Engfer matki oceniające swoje sześcioletnie nieśmiałe dzieci stwierdziły, że są one zmienne w nastrojach i mniej

14 B. Carducci, dz. cyt., s. 190.

15 Tamże, s. 208.

16 B. Harwas-Napierała, Nieśmiałość dziecka, Wydawnictwo Uniwersytetu Adama Mickiewicza, Poznań 1979, s. 39.

17 I. Dzwonkowska, dz. cyt., s. 83.

18 Tamże. 
kompetentne społecznie"19. Z przeprowadzonych przez Zabłocką badań wynika, że „dzieci nieśmiałe przejawiają istotnie niższy, niż dzieci śmiałe, poziom aktywności społecznej”20. Są mało ruchliwe. W związku z tym rzadko ulegają wypadkom i uszkodzeniom ciała. „W dzieciństwie nieśmiałość jest związana [...], z mniejszą ilością zachowań prospołecznych i pozytywnych strategii radzenia sobie, z rozwojem lęku oraz z symptomami depresji”"21. Philip Zimbardo i Shirley Radl dowiedli, że czynnikiem wyzwalającym nieśmiałość u dzieci w wieku przedszkolnym jest „spotykanie obcych” i „bycie w centrum uwagi”. Te czynniki powodują, że dziecko odczuwa zawstydzenie, strach, dyskomfort i niepewność.

Warto podkreślić inną cechę dzieci nieśmiałych, ich koncentrację: słuchają uważnie nauczyciela. Wszystkie jego polecenia realizują w skupieniu, w swoim indywidualnym tempie, nie buntując się. Dzięki temu nie są absorbujące. $Z$ wielką dokładnością i starannością wykonują powierzone im zadania, co może powodować dłuższy niż u innych dzieci czas pracy. Mają porządek na swoim miejscu pracy, „czysto” na biurku. „W trakcie zajęć szkolnych nie przerywają innym wypowiedzi i nie przeszkadzają na lekcjach, nie skupiają na sobie uwagi ani nauczycieli, ani uczniów"22. U tych dzieci można dostrzec dużą wrażliwość i ufność w stosunku do osób, które okażą im swoje zainteresowanie, pomoc, a także obdarzą dobrym słowem. Są ułożone, uporządkowane. Dzwonkowska pisze, że dzieci nieśmiałe: „są rozważne, mają umiejętność obserwowania, bogatą fantazję i godzinami potrafią same się bawić" ${ }^{\prime 2}$. Można zaobserwować, że czekają na swoją kolej, nie „przeciskają się” przez inne dzieci.

\section{Negatywne konsekwencje nieśmiałości w życiu dziecka oraz w funkcjonowaniu osoby dorosłej}

Jak zaprezentowano powyżej, brak wsparcia dziecka nieśmiałego ze strony pedagoga może powodować trudności w jego codziennej egzystencji, tj. w rzeczywistości szkolnej - w pełnieniu funkcji ucznia i członka społeczności szkolnej, a także w środowisku pozaszkolnym. Nieśmiałość sprawia, że dziecko ma trudności w ukazaniu swoich talentów i możliwości. Ma problemy z realizacją własnych marzeń i planów. „Dziecko nieśmiałe nie wierzy w siebie, w możliwość osiągnięcia sukcesu, toteż nie widzi sensu podejmowania działań. Brak aktywności rzeczywiście nie pozwala na osiągnięcie sukcesu, a to $\mathrm{z}$ kolei utwierdza je w przekonaniu, że nie warto podejmować trudu"24. Trudność nawiązywania kontaktów z innymi dziećmi może skutkować tym, że nie czuje się ono częścią grupy, nie czuje się lubiane. „Brak przyjaciół, więzi

\footnotetext{
19 Tamże.

${ }^{20}$ M. Zabłocka, dz. cyt., s. 35.

${ }^{21}$ I. Dzwonkowska, dz. cyt., s. 85.

22 Tamże, s. 86.

23 Tamże, s. 83.

${ }^{24}$ D. Gulińska-Grzeluszka, dz. cyt., s. 154.
} 
koleżeńskich powodować mogą u dziecka trudne do zaakceptowania poczucie izolacji społecznej, tęsknotę za bliskimi kontaktami z innymi ludźmi”25. Dziecko nieśmiałe może być też ignorowane i pomijane przez rówieśników, skoro ma trudności w rozmowie z innymi. Nieumiejętność zaprezentowania swojej wiedzy, brak śmiałości i poczucia własnej wartości skutkują tym, że „takie dzieci mają często opinię mniej zdolnych, co z pewnością jest bardzo krzywdzące i nieprawdziwe"26.

Brak okazanej pomocy dziecku nieśmiałemu na wczesnym etapie jego rozwoju może spowodować, że nieśmiałość stanie się czymś uciążliwym w dalszym życiu jako osoby dorosłej. Philip Zimbardo wymienia skutki, jakie niesie ze sobą nieśmiałość w egzystencji osób dojrzałych. Utrudnia ona „poznawanie nowych ludzi, zawieranie przyjaźni; przeszkadza w publicznej obronie własnych praw i wyrażaniu swoich opinii i wartości; przyczynia się do zakłopotania i nadmiernego przejmowania się własnymi reakcjami; utrudnia precyzyjne myślenie i skuteczne porozumiewanie się"27. Z nieśmiałością może współwystępować depresja, lęk, poczucie samotności, niezadowolenie z życia i pesymizm.

\section{Procedura badań własnych}

Badania zostały przeprowadzone w czerwcu 2017 roku. Ich terenem były wybrane szkoły podstawowe z oddziałami przedszkolnymi oraz przedszkola w Nowym Dworze Mazowieckim i Legionowie w województwie mazowieckim. Próbę badawczą stanowili nauczyciele wychowawcy z oddziałów zerowych. Przebadanych zostało 30 osób. W celu uzyskania odpowiedzi na postawione pytania badawcze posłużono się metodą sondażu diagnostycznego. Wykorzystano technikę ankiety pisemnej i narzędzie kwestionariusza ankiety. Ankieta składała się z 10 pytań.

\section{Analiza wyników badań własnych}

W tej części artykułu zostaną zaprezentowane wyniki z przeprowadzonego kwestionariusza ankiety. Analizy zawarte poniżej obejmują odpowiedzi na postawione $\mathrm{w}$ ankiecie pytania badawcze.

\section{Cechy osobowości, jakimi charakteryzuje się dziecko nieśmiałe w wieku przedszkolnym z perspektywy badanych pedagogów}

Badani wychowawcy zostali poproszeni o wypisanie cech osobowości, jakimi według nich wyróżnia się dziecko nieśmiałe. Najwięcej osób (14) stwierdziło, że dzieciom nieśmiałym brakuje wiary we własne siły, że są niepewne własnej wartości,

\footnotetext{
25 Tamże, s. 155.

26 Tamże, s. 156.

27 P.G. Zimbardo, Nieśmiałość, Wydawnictwo Naukowe PWN, Warszawa 2007, s. 20.
} 
mają zaniżoną samoocenę. Nauczyciele uważają, że dzieci nieśmiałe są: „ciche i małomówne” (12 osób), „zamknięte w sobie” (9 osób) i „spokojne” (7 osób). Następne wskazania to: „płaczliwe” (6 osób), „wstydliwe” (4 osoby), „zakłopotane”(2 osoby). Natomiast jedna osoba sądzi, że dzieci nieśmiałe są ostrożne w działaniach, spięte, mało spontaniczne i bardzo wrażliwe. Pedagodzy zaobserwowali także objawy wegetatywne (nadmierne pocenie się, czerwienienie się, jąkanie, zmiany na twarzy).

\section{Przejawiane zachowanie dziecka nieśmiałego w grupie przedszkolnej z perspektywy badanych nauczycieli}

Odpowiedzi ankietowanych nauczycieli na pytanie, jakie zachowanie dziecka nieśmiałego udało się Pani/Panu zaobserwować w grupie przedszkolnej, można podzielić na kilka grup. Dotyczą one: mowy niewerbalnej (unikanie kontaktu wzrokowego, postawa pochylona, cichy głos) - 14 wskazań; zachowania podczas uroczystości szkolnych (może reagować płaczem i niechęcią do występowania przed forum klasy) - 9 wskazań; zachowania podczas zabawy swobodnej (zabawa samotna bądź obok rówieśników) - 10 wskazań; zachowania w grupie rówieśniczej (ma problemy $\mathrm{z}$ wchodzeniem $\mathrm{w}$ relacje $\mathrm{z}$ rówieśnikami i dorosłymi, jest podporządkowane innym osobom, obserwuje to, co dookoła niego się dzieje, oraz nie zgłasza się na zajęciach) 14 wskazań.

\section{Problem nieśmiałości dziecka w wieku przedszkolnym w opiniach nauczycieli}

Wszyscy badani nauczyciele (30 osób) w trakcie swojej pracy zawodowej z dziećmi sześcioletnimi w oddziale zerowym mieli pod opieką dziecko nieśmiałe. Na pytanie, czy Pana/Pani zdaniem dziecko nieśmiałe potrzebuje wsparcia i indywidualnego podejścia ze strony nauczyciela, 26 osób odpowiedziało „zdecydowanie tak”, a 4 osoby - „raczej tak”.

\section{Zakres udzielanego dzieciom nieśmiałym wsparcia przez nauczycieli}

W szyscy przebadani nauczyciele (30 osób) jednomyślnie odpowiedzieli, że starają się wspomagać dziecko nieśmiałe w trudnej dla niego sytuacji. Wskazano na takie działania, jak: włączanie dziecka nieśmiałego do zabawy z innymi dziećmi [zabawy integracyjne (6 osób), muzyczno-ruchowe (1 osoba)]; dowartościowanie dziecka na forum grupy [powierzanie dziecku roli pomocnika (3 osoby), lidera w zabawie (3 osoby)]; kształtowanie pozytywnego obrazu samego siebie [stwarzanie sytuacji, aby dziecko mogło nabierać pewności siebie (10 osób), wzmacnianie poczucia wartości dziecka poprzez pochwały, wyróżnienie na forum grupy (13 osób)]; indywidualną pomoc dziecku [poprzez rozmowy (8 osób), motywowanie dziecka i angażowanie go w różne sytuacje i prace (5 osób), dostosowywanie wymagań i stawianie zadań do możliwości i umiejętności dziecka (4 osoby), bycie przy dziecku, żeby czuło się ważne (4 osoby), pomoc w wykonywaniu lub rozpoczęciu zadania (3 osoby)]. Nauczyciele zapytani o stosowane metody na ośmielenie dziecka podali następujące odpowie- 
dzi: zabawy integrujące (29 osób), techniki plastyczne i drama (25 osób), techniki relaksacyjne (23 osoby), bajkoterapia (21 osób), teatr i metoda Weroniki Sherborne (18 osób), muzykoterapia (16 osób), choreoterapia (3 osoby). Cała grupa badanych nauczycieli (30 osób) uczy dzieci, w jaki sposób witać się z innymi, jak nawiązywać rozmowę i jak przyłączać się do wspólnej zabawy. Nauczyciele także zachęcają dziecko nieśmiałe do wypowiadania się na forum grupy.

\section{Wnioski z przeprowadzonych badań}

Analizując odpowiedzi ankietowanych nauczycieli, należy wnioskować, że nieśmiałość jest to złożony problem. Jako cecha osobowości dziecka koreluje z cechami, które mogą utrudniać jego rozwój. Zachowania dziecka nieśmiałego wskazane przez nauczycieli mogą być przeszkodą w jego funkcjonowaniu w środowisku przedszkolnym. W tym kontekście wszyscy pedagodzy są zgodni, że dziecko nieśmiałe potrzebuje pomocy, uwagi, a także zaangażowania nauczyciela. Wśród udzielonych odpowiedzi można dostrzec, że pedagodzy dysponują wieloma możliwościami, aby wspomagać dziecko nieśmiałe - okazując wsparcie indywidualne oraz stosując metody i techniki arteterapeutyczne.

\section{Rekomendacje praktyczne}

Ważną umiejętnością osób pracujących z dzieckiem nieśmiałym w wieku przedszkolnym jest jego obserwacja - dostrzeżenie, jakie cechy i zachowania nieśmiałe ono przejawia, z jakimi trudnościami w funkcjonowaniu w grupie przedszkolnej się zmaga. Pozwoli to na przyjęcie właściwej strategii dydaktycznej, czyli na dobór odpowiednich metod, działań ze strony nauczyciela, by dziecko nieśmiałe mogło radzić sobie $\mathrm{z}$ tym, co stanowi dla niego barierę.

Badania wykazały, że znaczące w pracy z dzieckiem nieśmiałym staje się kształtowanie u niego pozytywnego obrazu siebie i zwiększanie samooceny. Wyniki badań ukazują konieczność stymulowania rozwoju emocjonalnego i społecznego dzieci nieśmiałych. Na uwagę zasługuje wrażliwość emocjonalna tych dzieci. Należy je uczyć rozpoznawania emocji, nazywania ich i wyrażania w społecznie akceptowalny sposób $^{28}$. Zgodnie z tym, co jest konieczne dla prawidłowego rozwoju emocjonalnego dziecka w wieku przedszkolnym, pedagog powinien zainteresować się odczuciami dziecka, zaspokoić jego podstawowe potrzeby psychiczne: bezpieczeństwa, miłości, stabilizacji uczuciowej oraz akceptacji i uznania ${ }^{29}$. Działania nauczyciela powinny

${ }^{28}$ A. Leszczyńska, Jak wspomagać rozwój emocjonalny dziecka, https://dziecisawazne.pl/jak -wspomagac-rozwoj-emocjonalny-dziecka/ (dostęp: 17.01.2018).

${ }^{29}$ A. Klim-Klimaszewska, Pedagogika przedszkolna, Instytut Wydawniczy Erica, Warszawa 2011, s. 45. 
być także skierowane na rozwój kompetencji społecznych dziecka nieśmiałego, ponieważ nieśmiałość ujawnia się w sytuacjach konfrontacji z otoczeniem - szczególnie trudnych dla tych dzieci. Wiążą się one z silnymi emocjami oraz wywołują zachowania nieśmiałe. W związku z tym, że zachowanie dziecka nieśmiałego charakteryzuje apatia, ostrożność w działaniach, należy stwarzać odpowiednie dla niego warunki do aktywności.

Oddziaływanie pedagogiczne względem dziecka nieśmiałego powinno być: indywidualne (zwracanie się wprost do dziecka, rozmawianie z dzieckiem) oraz grupowe (prowadzenie zabaw, realizowanie scenariuszy zajęć). Praca z całą grupą ma na celu kształtowanie tych umiejętności/zachowań, z którymi dziecko nieśmiałe ma trudność, wspólnie ze wszystkimi dziećmi. Aby dziecko nieśmiałe mimowolnie, nieświadomie pokonywało swoje trudności, lęki.

Ponadto niektóre zachowania dziecka nieśmiałego powinny zostać omówione $\mathrm{z}$ jego rodzicami, np. mowa niewerbalna, funkcjonowanie w społeczeństwie. Warto, aby częściej zwracali oni uwagę na utrzymywanie przez dziecko kontaktu wzrokowego z drugą osobą czy wypowiadanie zwrotów grzecznościowych. Nie należy zapominać o wzmacnianiu tych cech, którymi dzieci nieśmiałe się wyróżniają, a zostały wymienione powyżej.

\section{Podsumowanie}

Podsumowując powyższe rozważania, należy podkreślić, że pomoc dziecku nieśmiałemu w wieku przedszkolnym nie dotyczy zmiany jego osobowości. Wsparcie ma na celu próbę nauczenia go tych zachowań, z którymi ma kłopot, i spowodowanie, że będzie się ono czuło swobodnie w środowisku przedszkolnym. Wspomaganie powinno być ukierunkowane na pomoc w osiągnięciu wewnętrznego spokoju, który charakteryzuje się brakiem odczuwanego niepokoju, dyskomfortu, lęku. Kluczową rolą jest odpowiednie oddziaływanie pedagogiczne nauczycieli, aby nieśmiałość nie była źródłem cierpienia dla dziecka. Pedagog powinien tak organizować przestrzeń dydaktyczną i atmosferę w grupie przedszkolnej, aby dziecko nieśmiałe mogło w sposób beztroski spędzać czas dzieciństwa oraz się rozwijać. A przy tym, by zachowało te wszystkie pozytywne cechy, które posiada, i bogactwo swojej psychiki. Irena Obuchowska pisze: „Nieśmiałe dzieci... Przypominają ćmy: delikatne, niemal niewidzialne, ciche, rzadko w gromadzie, a gdy się je zbyt mocno uchwyci - można uszkodzić. Natomiast w swoim wnętrzu mają barwy motyli..." ${ }^{30}$.

${ }^{30}$ D. Gulińska-Grzeluszka, dz. cyt., s. 153. 


\section{Bibliografia}

Carducci B., Nieśmiałość. Nowe odważne podejście, Wydawnictwo Znak, Kraków 2008.

Dzwonkowska I., Nieśmiałość a wspierające i trudne relacje z ludźmi, Oficyna Wydawnicza Impuls, Kraków 2009.

Gładyszewska-Cylulko J., Wspomaganie rozwoju dzieci nieśmiałych poprzez wizualizację i inne techniki arteterapii, Oficyna Wydawnicza Impuls, Kraków 2010.

Goetz M., Cicha myszka w klasie, „Głos Nauczycielski”, nr 4/2014.

Gulińska-Grzeluszka D., Metody pracy z dzieckiem nieśmiałym w szkole, [w:] E. Przygońska (red.), Praca zdzieckiem wymagajacym, Wydawnictwo Adam Marszałek, Toruń 2011.

Harwas-Napierała B., Nieśmiałość dorosłych. Geneza - Diagnostyka - Terapia, Wydawnictwo Fundacji Humaniora, Poznań 1995.

Harwas-Napierała B., Nieśmiałość dziecka, Wydawnictwo Uniwersytetu Adama Mickiewicza, Poznań 1979.

Jackson J.S., Uwaga! Ważna zasada: „Nieśmiałość to nie wada!”, Wydawnictwo Święty Paweł, Częstochowa 2008.

Klim-Klimaszewska A., Pedagogika przedszkolna, Instytut Wydawniczy Erica, Warszawa 2011.

Krauze-Sikorska H., Dziecko nieśmiałe, „Edukacja i Dialog”, nr 6(179)/2006.

Leszczyńska A., Jak wspomagać rozwój emocjonalny dziecka, https://dziecisawazne.pl/ jak-wspomagac-rozwoj-emocjonalny-dziecka/ (dostęp: 17.01.2018).

Mika S., Psychologia społeczna, Państwowe Wydawnictwo Naukowe, Warszawa 1987.

Ratajek A., Śmielej o nieśmiałości. Nieśmiałość dziecka jako ważny problem wychowawczy, „Nowe Horyzonty Edukacji”, nr 4(1)/2015.

Siuta J., Słownik psychologii, Wydawnictwo Zielona Sowa, Kraków 2015.

Zabłocka M., Przezwyciężanie nieśmiałości u dzieci, Wydawnictwo Naukowe Scholar, Warszawa 2008.

Zabłocka M., Zrozumieć nieśmiałość. Aspekty diagnostyczne i terapeutyczne, Wydawnictwo Kazimierza Wielkiego, Bydgoszcz 2012.

Zimbardo P.G., Nieśmiałość, Wydawnictwo Naukowe PWN, Warszawa 2007. 
A picture of and support for the timid child in the perception of pre-school education teachers

Abstract: This article analyses the image of a shy child of pre-school age and the scope of assistance provided to him/her by the pre-school education teacher. The difficulties that a shy child faces in pre-school are discussed and pedagogical solutions advanced.

Keywords: timidity, timid child, pre-school child, pre-school education teacher

About the author: Małgorzata Mróz - Master of pedagogy, graduate of the Faculty of Educational Sciences of the Cardinal Stefan Wyszyński University in Warsaw, Poland. Academic interests: pre-school education and early-school education, timidity of the child, inclusive education of pupils with special educational needs. 
Obszar zainteresowań czasopisma naukowego „Kultura i Wychowanie” z założenia ma szeroki zakres. Odwołuje się do zagadnień związanych z interdyscyplinarną relacją kultury i wychowania.

Prezentowane wyniki badań naukowych, głównie z obszaru pedagogiki, ujmowane są w dwa bloki tematyczne rozpraw: filozoficzno-historyczne oraz teoretyczno-empiryczne.

Wersja internetowa, będąca podstawową formą publikacji, dostępna pozostaje na stronie: www.pedagogika.pl

Zespół redakcyjny 